\title{
THE BIRD-LIFE OF LONDON
}

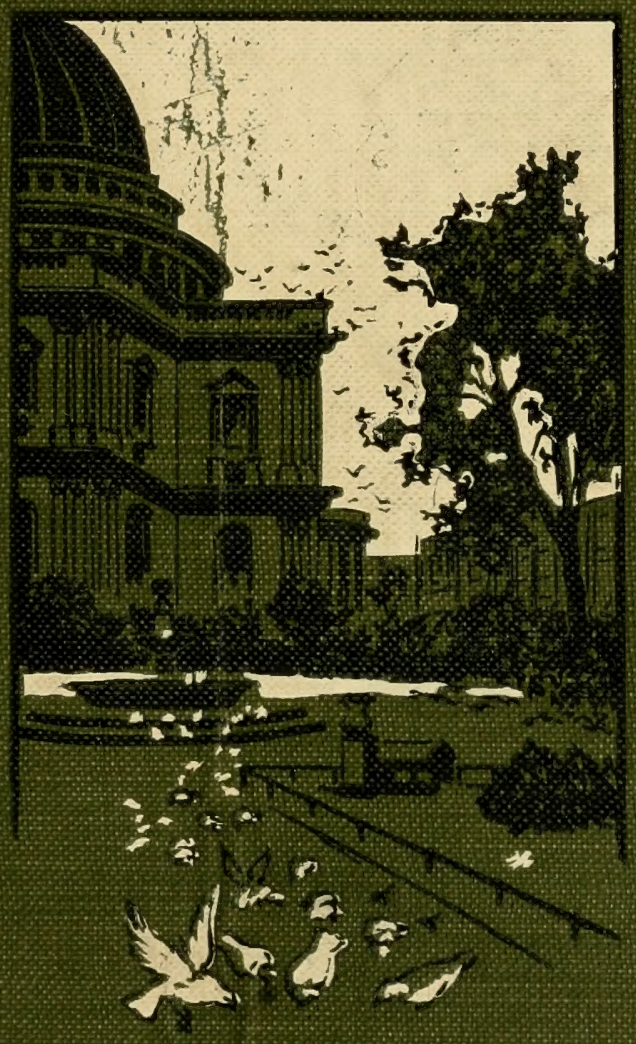




\section{Smithsonian Institution}

Sibraries

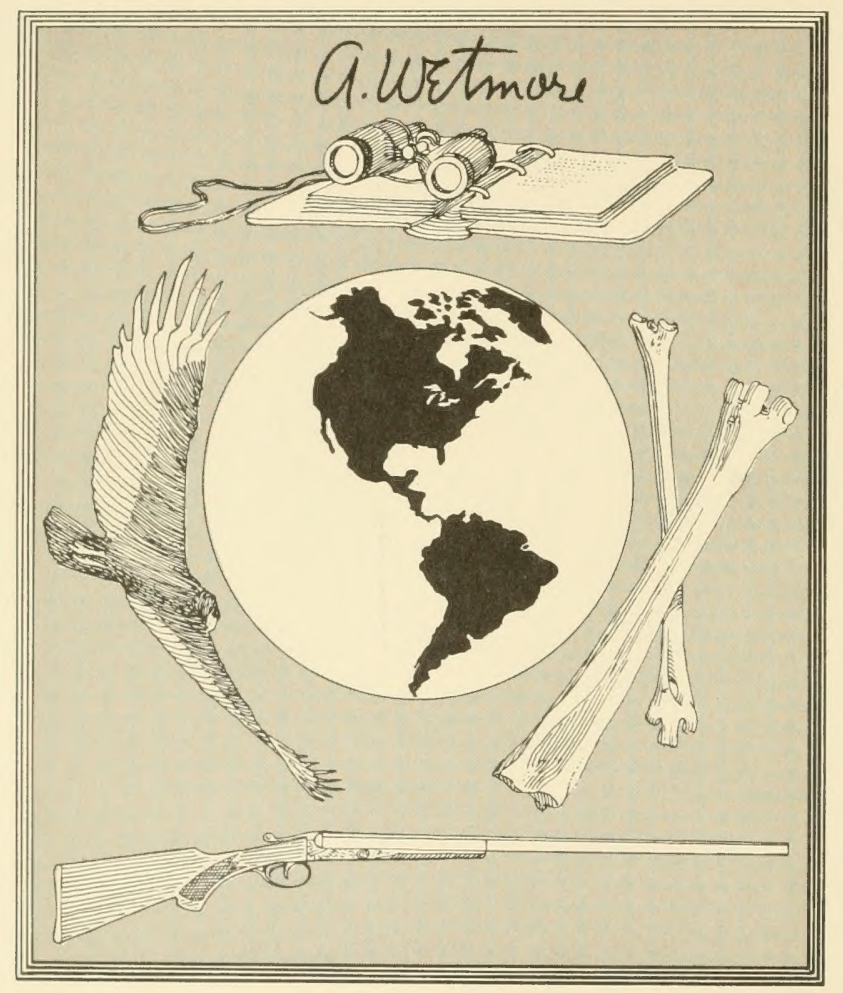

Alexander Wetmore 1946 SixthSecretary 1953 32 
Qlex Wrtmore 



\section{THE BIRD-LIFE OF LONDON}


A COUNTRY-SIDE CHRONICLE. By S. L. BENSUSAN. With Illustrations by Carton Moore-PARK, Demy 8vo, 7s, 6d. net.

THE COUNTRY DAY BY DAY. BY E. Kay Robinson. Illustrated. Crown 8vo, 6s.

$$
\text { go }
$$

THE DAINTY NATURE SERIES

Each Volume Illustrated, price 5s, net.

CAMERA AND COUNTRYSIDE. By A. R. DUGMORE.

AMONG THE WATER-FOWL. By H. K. Јов.

NATURE BIOGRAPHIES. The Lives of Some Everyday Butterflies, Moths, Grasshoppers, and Flies, By Clarence Moores Weed.

HOW TO ATTRACT THE BIRDS, AND OTHER TALK ABOUT BIRD NEIGHBOURS. By Neltje Blanchan.

THE NATURE STUDY IDEA. By L. H. BAILEY.

THE BROOK BOOK. BY M. R. MiLler.

$$
\text { go }
$$

LONDON : WILLIAM HEINEMANN

2 I Bedford Street, W.C. 


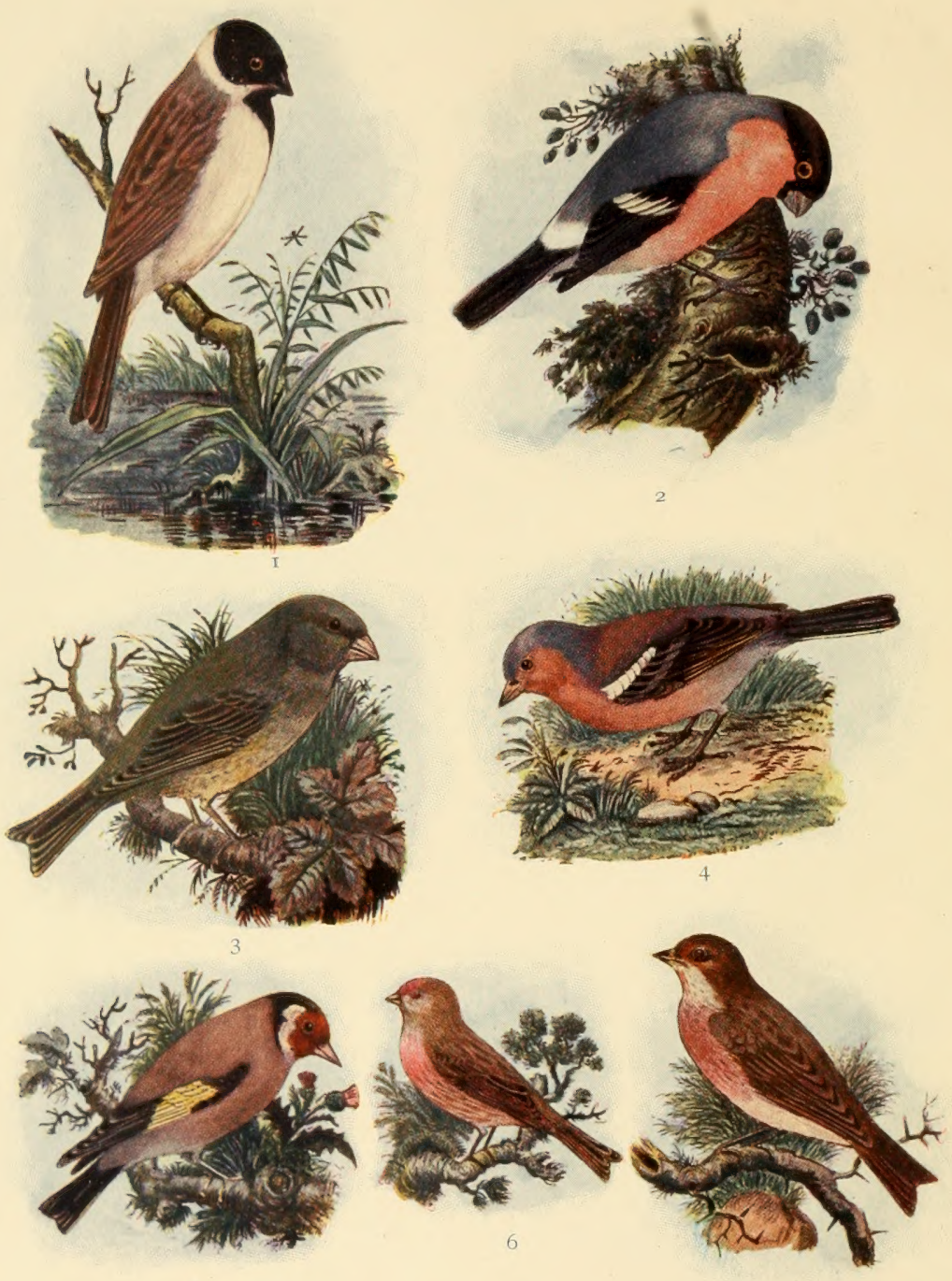
5

Reed Bunting. 2. Bullfinch. 3. Greenfinch. 4. Chaffinch. 5. Goldfinch. 6. Lesser Redpole. 7. Linnet. 


\author{
BY \\ CHARLES DIXON
}

WITH ILLUSTRATIONS IN

COLOUR AND BLACK AND WHITE
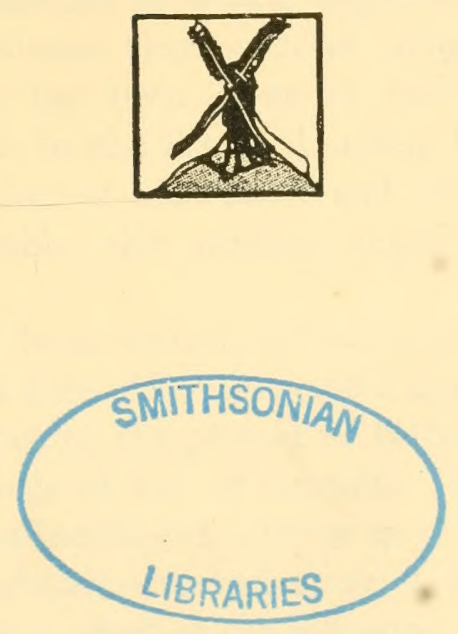

\author{
LONDON \\ WILLIAM HEINEMANN \\ 1909
}




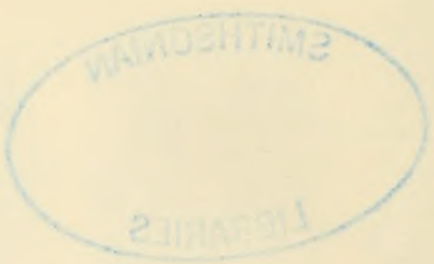

Copyright, London, 1909, by William Heinemann 


\section{PREFACE}

THE present volume is the result of many years' observation of the Bird-Life of London. For the past eight years a more or less continuous residence in the Metropolis has enabled me not only to arrange the many notes already in my possession (some of these date back to I880), but to devote a considerable time to the special study of its avifauna.

The species dealt with include all that are found resident within the fifteen-mile radius; all that visit that area either as summer or winter migrants; and, finally, the casual wanderers that occur at irregular intervals. A brief history has been given of each species fairly claiming a place in the list of London birds, together with a description of the adult and young plumage, which will enable the student readily to identify them.

My book has been written to encourage the observation of the Bird-Life of London, and I hope it may prove of some assistance to the pursuit of Nature-study in the elementary schools of the Metropolis. Most suburban residents take an intelligent interest in the birds of their particular neighbourhood, and these, I trust, may find something of use to them in the following pages.

My radius of fifteen miles may seem a somewhat wide one; but in these days, when space is annihilated, I may be forgiven the extension, although it includes 


\section{PREFACE}

in each direction, very fairly, the limits of the Great Metropolis.

The series of singularly life-like pictures which adorns the following pages has been drawn by my old friend Mr. John Duncan, of Newcastle. I am indebted to the proprietors of the Newcastle Weekly Chronicle for permission to use them here, and to them I desire to tender my best thanks for the favour.

Charles Dixon

LoNDON, IgO9 


\section{CONTENTS}

\section{INTRODUCTION}

The Peregrine Falcon (Falco peregrimus) I 2

The Новву (Falco subbuteo)

The Kestrel (Falco tinnunculus)

The Sparrow-Hawk (Accipiter nisus)

The Barn Owl (Strix flammen)

Thr. Tawny Owe (Symium aluco)

The Long-eared Owl (Asio otus)

The Blackbird (Merula vulgaris)

The Ring-Ouzel (Merula torquata)

The Fieldfare (Turaus pilaris)

Tife Redwing (Turdus iliacus)

The Song Thrush (Turdus musicus)

The Missel-Thrush (Turdus viscivorus)

The Robin (Eritbacus rubecula)

The Nightingale (Daulias luscinia)

The Redstart (Ruticilla phoenicurus)

The Wheatear (Saxicola onanthe)

The Whinchat (Pratincola rubetra)

The Stonechat (Pratincola rubicola)

The Hedge Accentor (Accentor modularis)

The Grasshopper Warbler (Locustella navia)

The Reed Warbler (Acrocephalus arundinaceus)

The Sedge Warbler (Acrocephalus phragmitis)

The Whitethroat (Sylvia cinerea)

The Lesser Whitethroat (Sylvio curruca)

The Garden Warbler (Sylvia hortensis)

The Blackcap (Syluia aticapilla)

The Dartford Warbler (Sylvia provincialis)

$8 \mathbf{I}$

The Wood Warbler (Phylloscopus sibilatrix)

The Willow Warbler (Phylloscopus trochilus) 


\section{CONTENTS}

The Chiffchaff (Pbylloscopus rufus)

The GoldCrest (Regulus cristatus)

The Wren (Troglodytes parvulus)

The Creeper (Certhia familiaris)

The Nuthatch (Sitta casia)

The Great Titmouse (Parus major)

IOI

The Blue Titmouse Parus ccruleus)

The Coal Titmouse (Parus ater; sub-sp. britannicus)

The Marsh Titmouse (Parus palustris)

The Long-tailed Titmouse (Acredula rosea)

The Pied Wagtail (Motacilla yarrelli)

The White Wagtail (Motacilla alba)

The Grey Wagtail (Motacilla sulphurea)

120

The Yellow Wagtail (Motacilla raii)

122

The Tree Pipit (Anthus arboreus)

The Meadow Pipit (Anthus pratensis)

The Skylark (Alauda arvensis)

The Wood Lark (Alauda arborea)

The Common Bunting (Emberiza miliaria)

The Yellow Bunting (Emberiza citrinella)

The Cirl Bunting (Emberiza cirlus)

The Reed Bunting (Emberiza schreniclus)

The Snow Bunting (Emberiza nivalis)

The Chaffinch (Fringilla calebs)

The Brambling (Fringilla montifringilla)

I 5 I

The House Sparrow (Passer domesticus)

The 'Tree Sparrow (Passer montanus)

The Hawfinch (Coccothraustes vulgaris)

160

The Greenfinch (Ligurinus chloris)

I 62

The Goldfincu (Carduelis elegans)

165

168

THe Siskin (Chrysomitris spinus)

The Lesser Redpole (Linota rufescens)

THE Linnet (Linota cannabina)

The Twite (Linota flavirostris)

The Bullfinch (Pyrrhula vulgaris)

181

The Crossbill (Loxia curvirostra) 


\section{CON'TENTS}

The Spotted Flycatcher (Muscicapa grisola)

The Pied Flycatcher (Muscicapa atricapilla)

The Red backed Shrike (Lanius collurio)

The W AXwing (Ampelis garrulus)

The Starling (Sturnus vulgaris)

The Raven (Corvus corax)

The Carrion Crow (Corvus corone)

The Hooded Crow (Corvus cornix)

THE Rook (Corvus frugilegus)

The Jackdaw (Corvus monedula)

The Magpie (Pica caudata)

The JAY (Gorrulus glandarius)

The Swallow (Hirundo rustica)

Thd House Martin (Chelidon urbica)

The Sand Martin (Cotyle riparia)

The Swift (C'ypsclus apus)

The Green Woodpecker (Gecinus viridis)

The Great Spotted Woodpecker (Picus major)

The Lesser Spotted Woodpecker (Picus minor)

The Wryneck (lynx torquilla)

The Cuckoo (Ciuculus canorus)

The Kingfisher (Alcedo ispida)

The Nightjar (Caprimulgus europacus)

The Ring Dove (Columba palumbus)

The Sтоск Dove (Columba anas)

252

The Turtle Dove (Turtur nuritus)

255

The Pheasant (Phasionus colcbicus)

258

The Partridge (Perdix cinerea)

$26 \mathrm{I}$

The Golden Plover (Charadrius pluvialis)

$26+$

The Lapwing (Vancllus cristatus)

The Ringed Plover (Agialitis hiaticula)

The Common SAndpiper (Totanus hypoleucus)

272

The Curlew (Numenius arquata)

The Common Whimbrel (Numenius phceopus)

278

The Woodcock (Scolopax rusticula)

281

The Common Snipe (Gallinago scolopacina) 


\section{CONTENTS}

The JaCk Snipe (Limnocryptes gallinula)

PAGE

The Black-Headed Gull (Larus ridibundus)

Other Gulls and Terns (Larina) (Sternina)

The Corn Crake (Crex pratensis)

THe Water Hen (Gallinula chloropus)

299

The Cоот (Fulica atra)

302

The Heron (Ardea cinerea)

The Great-crested Grebe (Podiceps cristatus)

The Little Grebe (Podiceps minor)

3 I I

The Mallard (Anas boschas)

The Common Teal (Nettion crecca)

The Wigeon (Mareca penelope)

320

The Pochard (Nyroca ferina)

The Tufted Duck (Fuligula cristata)

LOCAL LIST

INDEX 


\section{LIST OF ILLUSTRATIONS}

\section{COLOUR}

Reed Bunting, Chaffinch, Greenfinch, Goldfinch, Lesser

Blue Titmouse, Longtailed Titmouse, Grey Wagtail, Tree Pipit, Skylark

Starling, Jackdaw, Magpie, Common Jay, Barn Swallow

Green Woodpecker, Cuckoo, Common Kingfisher,

Golden Plover, Lapwing

Black-headed Gull, Corn Crake, Common Coot, Common Teal

\section{BLACK AND WHITE}

Peregrine Falcon, Hobby, Kestrel

Long-eared Owl, Wood Owl

Ring - Ouzel, Fieldfare, Redwing, Missel - Thrush, Wheatear, Whinchat, Stonechat

Grasshopper Warbler, Reed Warbler, Sedge Warbler,

Lesser Whitethroat, Garden Warbler, Blackcap

Warbler, Chiffchaff, Goldcrest, Wood Wren

Great Titmouse, Coal Titmouse, Marsh Titmouse, Pied Wagtail, White Wagtail, Yellow Wagtail, Meadow Pipit 


\section{LIST OF ILLUSTRATIONS}

Corn Bunting, Yellow Bunting, Cirl Bunting, Snow

Bunting, Brambling, House Sparrow, Tree Sparrow, Haw finch, Siskin, Twite

Common Creeper, Wood Lark, Common Crossbill,

Spotted Flycatcher, Pied Flycatcher, Red-backed Shrike, Waxwing

Raven, Carrion Crow, Hooded Crow, Rook

House Martin, Sand Martin, Common Swift, Great

Spotted Woodpecker, Lesser Spotted Woodpecker, Wryneck, Red-necked Nightjar

Ring Dove, Stock Dove, Turtle Dove

Grey Plover, Greater Ringed Plover, Lesser Ringed Plover, Jack Snipe

Common Sandpiper, Wood Sandpiper, Redshank, Green Sand piper

Kittiwake, Spotted Crake, Water Rail, Water Hen

Common Heron, Great-crested Grebe, Mute Swan 


\section{INTRODUCTION}

LONDON has often been described as a "wilderness of bricks and mortar," or as a " desert of houses"; but surely the least observant of its citizens would protest nowadays against such an obvious libel, and with very good reason. There are few spots, even in the centre of this vast Metropolis, where the lover of Nature may not find something of interest; he cannot wander far in any direction without having some reminder of more rural scenes. Not only so: now that Nature-study occupies such a prominent place in the educational course of the Council's elementary schools, steps are being taken on every side to preserve and encourage that Wild Life which not only beautifies London, but elevates its citizens, and exerts a priceless influence upon the receptive minds of the young. A warning note, however, is necessary. Now that the "schoolmaster is abroad" in downright earnest it cannot be too strongly impressed upon the responsible authorities that the Nature-knowledge imparted should be of a sound, reliable character. It is just as easy to teach facts as to impart errors; and the teacher must have a sound knowledge of the subject in which he essays to instruct, but I regret to say, speaking as far as birds are concerned, that this is only too often of an unreliable, and even downright fictitious, character. I have examined many of the text-books now in the hands of elementary teachers, and I must confess myself amazed at the quality of the information they contain. This seems to imply that the compilers of these books do not possess the necessary knowledge to enable them to separate sound facts from the glaring errors only too palpable to the specialist. In some of them the Swift is spoken of as a "Swallow," the nests of certain common birds are quite crroncously described, as are the cggs, 


\section{THE BIRD-LIFE OF LONDON}

and the most elementary facts concerning food, migration, and so forth are woefully inaccurate. So far as London is concerned, there are plenty of common birds found in the vicinity of most of the Council schools which might and should serve as object-lessons and as capital examples for teaching the rudiments of ornithology. The opportunity in most cases is lost. At the end of the present chapter I propose to offer a few suggestions for the "Nature-study" of birds in the London schools.

The Bird-life of London presents a most fascinating study to any one who cares to pursue it. A lifetime among the birds may be profitably spent well within the fifteen-mile radius. Not only do the residents and regular migrants offer scope for endless study, but the casual visitors are a source of great interest in themselves. Migration, that fascinating drama of the air, may be investigated with profit. The study of birds within the Metropolis offers a field of research absolutely denied to the ornithologist in more rural surroundings. This is in relation to the ways of birds under more or less abnormal conditions, which illustrate in a wonderful manner their adaptability to novel circumstances. Some species, as we know, have been banished from London; others, more adaptable, have maintained their existence through the changing years; others yet again have even invaded the Great City and established themselves in a most remarkable way. As time goes on there seems to be every probability that more species will also succeed in doing so. 'Time was, as we know by old records, when the Kite was almost as familiar in London's streets as the Sparrow is now, and the work of the modern scavenger was largely left to this useful species, as it is to-day in many Southern towns. The Swifts used to circle and glide over what are now the densest parts of the city; the Martins and Swallows used to thread the narrow 


\section{IN'TRODUC'TION}

streets of timber houses, of which almost the last surviving relic stands in Holborn to-day; Woodcocks used formerly to be shot near Piccadilly; and the usual bird fauna of the fields must once have occupied situations which are now nothing but houses. Even the historical study of the ornithology of London is a most fascinating one, deserving a volume to itself. In modern days the casual bird visitors to the Metropolis are many and interesting; that is to say, the examples that are observed or obtained. 'That old veteran ornithologist the late Herr Gätke used to say that he would gladly exchange all his wonderful collection of rare birds, obtained during a lifetime spent on the tiny island of Heligoland (many times smaller than London), for those that had passed over it unrecorded and unobserved. The same might be said of London. We are constantly getting evidence of the birds that pass over the vast city, which indicates amazing possibilities if our bird pilgrims could only be recognised. The harvest is great, but unfortunately the labourers are few. We want more intelligent observers of the Bird-life of London, and the present little book has been written largely with the purpose of winning recruits and stimulating work in this direction. London already can claim not a few remarkable records, which will be found in the analytical table appended to this chapter. Some of these occurrences are simply astonishing. There was, for instance, the Puffin that flew through a window in Brook Street-curiously enough, the residence then occupied by the late Lord Lilford, President of the Ornithologists' Union, and a great lover of birds. The Forktailed Petrel and the Stormy Petrel have been captured in the London streets, attracted by the lights and pools of water; the Guillemot has come up the Thames to London; the Alpine Swift has been shot at Finchley; the Osprey has visited Richmond Park. Commoner species are repeatedly turning up in the least likely 


\section{THE BIRD-LIFE OF LONDON}

localities: the Sedge Warbler has been obtained on the roof of the Agricultural Hall, at Islington, the Goldcrest in the Big Wheel, the Sparrow-Hawk at Guy's Hospital, the Woodcock in the Strand. Many other instances might be given, but sufficient has been said to indicate possibilities and stimulate watchfulness. During winter the game-dealers' shops are a study in themselves, especially Leadenhall Market, where from time to time some of our rarest bird visitors find their way for sale in the Metropolis. A fair collection of rare birds could be obtained in this locality alone by the enterprising naturalist. But this is only a side question of London ornithology.

The migration of birds over London, I am convinced, is on a very much vaster scale than is generally supposed. Much evidence of this is set forth in the following pages. The very size of the Metropolis suggests that it must of necessity be crossed by large numbers of birds on their way northwards from the Sussex coast, which we know to be a district singularly favourable to the phenomenon. London lies in the direct path of many of these journeying birds. A few alight within London's limits; some of these are detected, others pass on without a call, but sufficiently near to be recognised. During the migration in spring and autumn the cries of passing birds may be repeatedly heard from the night sky; and there can be no reasonable doubt that the millions of lights in the great city attract vast numbers of these feathered pilgrims, especially during cloudy weather, when they are apt to get off their course or completely to lose their way. It is no uncommon thing to see bunches of Plovers or long skeins of Ducks and Geese, often in a V-like formation, at a great height in the sky on passage over London. During these periods in spring and autumn a sharp look-out should be kept in parks and gardens, or in any place where trees and bushes occur, for migrants which 4 
have been tempted to the earth for a brief rest. 'Then there is the matter of observing the times of arrival and departure of the many migratory species that visit London regularly, either to breed or to spend the winter; also the numerous local movements of birds that are more or less resident within our limits. In fact, London, so far as its bird-life is concerned, is a self-contained centre in many respects, and well worthy of systematic observation. The gradual extension of range of certain species within the Metropolis is another point of exceptional interest, the various favourable or unfavourable influences aiding or checking expansion well repaying careful and intelligent study. The distribution of many birds within our radius is as yet very imperfectly known.

The magnificent parks and open spaces, the many squares and gardens, the delightfully rural suburbs, must ever prove increasingly attractive haunts for birds. The waters are equally charming and alluring. The care that is bestowed upon these places, the way they are so constantly watched and guarded and their charms preserved, all favour and encourage bird-life; and if a little greater vigilance could be shown in exterminating rats and keeping cats (which should be shot at sight) outside these beautiful spots, there seems to be no end to the possibilities regarding birds that might be induced to take up their quarters within London's limits. I am, however, utterly opposed to the suggestions that have been made with respect to the introduction of exotic species. Our own avifauna can supply every need; and a little judicious management would, I am convinced, induce many of our gayest and most charming birds to take up their permanent residence in many of these places. In some of the parks small aviaries have been established, and it seems ungenerous to write a word against them. I, however, am pleading for wild birds alone. We cannot have too many in the Metropolis, 


\section{THE BIRD-LIFE OF LONDON}

where their pleasing plumage, engaging ways, and charming music will ever furnish a rich store of amusement and recreation for those who are doomed to pass their lives far from the green countryside, with all its beneficent influences. 'Then the rapid, luxurious, and cheap means of transit nowadays to all parts of the London area make the study of London's birds much easier and pleasanter than formerly. A short, quick journey in any direction renders a visit to the haunts of any special or particular bird a matter of little trouble or expense. In the following pages, under the heading of each species, a carefully worked-out distribution has been given, whilst the table at the end of this chapter will show at a glance the general habitat. Finally, I may add that everything possible should be done not only to induce birds to visit and remain in London, but to encourage their intelligent study, especially by the young. From a social and moral point of view alone the trifling expenditure involved will prove an investment of the greatest value to the community. That enterprising body the London County Council, to which citizens are indebted far more than they realise for endless improvements and advantages, might be induced to do a little more in beautifying the Great City from an ornithological point of view. I would suggest that some competent person be appointed to watch over the natural history of the Council's parks and open spaces. His duties should be to protect and extend the London avifauna (by local Acts where necessary), and to record and report facts concerning it, with the assistance of the many intelligent keepers and rangers employed in these places. $\mathrm{He}$ should also be competent to direct the Nature-study of the elementary schools, and to suggest to teachers the most suitable material available in each special area. Children would then become familiar with the natural objects to be found in their own neighbourhoods. It 6 


\section{INTRODUC'TION}

need not be a very expensive experiment, and I am convinced that the outlay would not only be amply repaid, but, which is more to the point, receive the cordial approval of the general public. A monthly report in the daily Press would serve as a guide to the public concerning all that is going on in the bird-world of London, and where specially interesting facts might be observed.

A word now in conclusion respecting the Nature-study of Bird-life in the London elementary schools. This should be pursued in each and every case strictly and exclusively, as far as possible, with a view to Loca! conditions. The birds found in the district in which the school is situated should form the objects of study; and in this way the elementary facts of avine dispersal and distribution may be illustrated. In this way may be demonstrated how certain birds inhabit certain localities; why they do so; how they do so. The harmony of species with their environment, the adaptability of species or the lack of it, with its results, are other questions bearing upon this branch of study. Then comes the matter of species being sedentary or migratory. Why are they so? 'This leads on to the subject of avine migration and local movements; the cause (not lack of food, as so many teachers insist), the destination, and so on. With migratory species the times of arrival and departure, the duration of the stay, the object of the visit, must all be dealt with; and in the case of sedentary species the various movements, non-migrational, but sufficiently marked, will require notice. Then comes the structure, the habits, and economy of the birds selected for study, care being taken to lay stress upon the fact that these birds are typical of groups, to which such structure and habits are common. The Sparrow may be taken, for instance, as typical of the Finches, the Thrush and the Robin of another group, the Wren of 


\section{THE BIRD-LIFE OF LONDON}

another, the Starling of another, the Rook and the Dove of others, and so forth. They should be taken as illustrative examples of as many of the broad facts of general ornithology as may be possible; but this at a later stage of study. Then comes the school museum. Too often this is a mere cupboard full of odds and ends and rubbish of no use whatever from an educational point of view. Each should contain at least stuffed specimens of the common birds of the neighbourhood, together with a set of models of the eggs of the commoner species. A school museum should be organised on lines that illustrate the course of instruction, and uniformity of arrangement should be followed.

\section{ANALYTICAL TABLE OF THE BIRDS OF LONDON}

\begin{tabular}{|l|l|l|}
\hline \multicolumn{1}{|c|}{ SPECIES } & \multicolumn{1}{|c|}{ status } & Distribution \\
\cline { 2 - 3 } Osprey & Accidental visitor & Richmond \\
Peregrine Falcon & Irregular visitor & General \\
Hobby & Occasional visitor & General \\
Kestrel & Resident & General \\
Sparrow-Hawk & Resident & General \\
Barn Owl & Resident & General \\
Tawny Owl & Resident & General \\
Long-eared Owl & Resident & General \\
Blackbird & Resident & General \\
Ring-Ouzel & Migration & General \\
Fieldfare & Winter visitor & General \\
Redwing & Winter visitor & General \\
Song Thrush & Resident & General \\
Missel-Thrush & Resident & General \\
Robin & Resident & General \\
Nightingale & Summer migrant & General \\
Redstart & Summer migrant & General \\
Wheatear & Summer migrant & General \\
Whinchat & Summer migrant & General \\
Stonechat & Resident & General \\
& & \\
\hline
\end{tabular}


INTRODUCTION

ANALTTICAL 'TABLE OF 'THE BIRDS OF I.ONDON-continucd

\begin{tabular}{|l|l|l|}
\hline \multicolumn{1}{|c|}{ sPecies } & \multicolumn{1}{|c|}{ status } & DIsTRIBuTIoN \\
\hline Hedge Accentor & Resident & General \\
Grasshopper Warbler & Summer migrant & General \\
Reed Warbler & Summer migrant & Thames and Colne \\
& Valleys \\
Sedge Warbler & Summer migrant & General \\
Whitethroat & Summer migrant & General \\
Lesser Whitethroat & Summer migrant & General \\
Garden Warbler & Summer migrant & General \\
Blackcap & Summer migrant & General \\
Dartford Warbler & Resident & Surrey and Kent \\
Wood Warbler & Summer migrant & General \\
Wiilow Warbler & Summer migrant & General \\
Chiffchaft & Summer migrant & General \\
Goldcrest & Resident & General \\
Wren & Resident & General \\
Creeper & Resident & General \\
Nuthatch & Resident & General \\
Great Titmouse & Resident & General \\
Blue Titmouse & Resident & General \\
Coal Titmouse & Resident & General \\
Marsh Titmouse & Resident & General \\
Long-tailed Titmouse & Resident & General \\
Pied Wagtail & Resident & General \\
White Wagtail & Summer migrant & North and west \\
Grey Wagtail & Winter visitor & General \\
Yellow Wagtail & Summer migrant & General \\
Tree Pipit & Summer migrant & General \\
Meadow Pipit & Resident & General \\
Skylark & Resident & General \\
Wood Lark & Resident & General, but local \\
Common Bunting & Resident & General; rarer in east \\
Yellow Bunting & Resident & General \\
Cirl Bunting & Resident & Local and rare \\
Reed Bunting & Resident & General; riparian \\
Snow Bunting & Winter visitor & General and local \\
Chaffinch & Resident & General \\
Brambling & Winter visitor & General \\
House Sparrow & Resident & General \\
Tree Sparrow & Resident & General and local \\
\hline & & \\
\hline
\end{tabular}


ANALYTICAL TABLE OF 'THE BIRDS OF LONDON-continued

\begin{tabular}{|c|c|c|}
\hline SPECIES & STATUS & DISTRIBUTION \\
\hline Hawfinch & Resident & General \\
\hline Greenfinch & Resident & General \\
\hline Goldfinch & Resident & General \\
\hline Siskin & Winter visitor & General \\
\hline Lesser Redpole & Winter visitor chiefly & General \\
\hline Jinnet & Resident & General \\
\hline 'Twite & Winter visitor & Local \\
\hline Bullfinch & Resident & General \\
\hline Crossbill & Winter visitor chiefly & Local \\
\hline Spotted Flycatcher & Summer visitor & General \\
\hline Pied Flycatcher & Summer visitor & Northern \\
\hline Red-backed Shrike & Summer visitor & General \\
\hline Waxwing & Winter visitor & Local \\
\hline Starling & Resident & General \\
\hline Raven & Occasional visitor & Local \\
\hline Carrion Crow & Resident & General \\
\hline Hooded Crow & Winter visitor & North and west \\
\hline Rook & Resident & General \\
\hline Jackdaw & Resident & General \\
\hline Magpie & Resident & General \\
\hline Jay & Resident & General \\
\hline Swallow & Summer visitor & General \\
\hline House Martin & Summer visitor & General \\
\hline Sand Martin & Summer visitor & General \\
\hline Swift & Summer visitor & General \\
\hline Alpine Swift & Migration & Finchley, August I 860 \\
\hline Green Woodpecker & Resident & General and local \\
\hline $\begin{array}{l}\text { Great Spotted Wood- } \\
\text { pecker }\end{array}$ & Resident & General and local \\
\hline $\begin{array}{l}\text { Lesser Spotted Wood- } \\
\text { pecker }\end{array}$ & Resident & General and local \\
\hline Wryneck & Summer visitor & General and local \\
\hline Cuckoo & Summer visitor & General \\
\hline Kingfisher & Resident & General and local \\
\hline Nightjar & Summer visitor & General and local \\
\hline Ring Dove & Resident & General \\
\hline Stock Dove & Resident & General \\
\hline Turtle Dove & Summer visitor & General \\
\hline Pheasant & Resident & Local \\
\hline
\end{tabular}


INTRODUCTION

ANALYTICAL TABLE OF THE BIRDS OF LONDON-continued

\begin{tabular}{|c|c|c|}
\hline SPECIES & STATUS & DISTRIBUTION \\
\hline Partridge & Resident & Local \\
\hline Red-legged Partridge & Accidental visitor & Local \\
\hline Quail & Accidental visitor & Local \\
\hline Golden Plover & Winter visitor & Local \\
\hline Grey Plover & Winter visitor & Forest Gate, I87I \\
\hline Lapwing & Resident & Local, but general \\
\hline Ringed Plover & Migration & Local \\
\hline Greater Ringed Plover & Migration & Local \\
\hline Stone Curlew & Migration & Local \\
\hline Common Sandpiper & Summer visitor & Non-breeding; pas- \\
\hline Wood Sandpiper & Migration & Local [sage \\
\hline Redshank & Migration & Local \\
\hline Green Sandpiper & Migration & Local \\
\hline Curlew & Migration & Local \\
\hline Whimbrel & Migration & Local \\
\hline Woodcock & Migration & Local Has nested \\
\hline Common Snipe & Winter visitor & General \\
\hline Jack Snipe & Winter visitor & General \\
\hline Black-headed Gull & Winter visitor & General and local \\
\hline Gulls and Terns & Winter and passage & General and local \\
\hline Corn Crake & Summer visitor & General and local \\
\hline Spotted Crake & Migration & General and local \\
\hline Water Rail & Casual wanderer & General and local \\
\hline Water Hen & Resident & General \\
\hline Coot & Resident & General and local \\
\hline Heron & Resident & General and local \\
\hline Great-crested Grebe & Resident & General and local \\
\hline Little Grebe & Resident & General and local \\
\hline Mallard & Resident & General and local \\
\hline Teal & Winter visitor & General and local \\
\hline Widgeon & Winter visitor & General and local \\
\hline Pochard & Winter visitor & General and local \\
\hline Tufted Duck & Winter visitor & General and local \\
\hline Scaup & Winter visitor & Wanstead \\
\hline Swans and Geese & Winter visitors & General and local \\
\hline Smew & Winter visitor & $\begin{array}{l}\text { St. James's Park, 1907, } \\
\text { \&c. }\end{array}$ \\
\hline Puffin & Winter visitor & Brook Street \\
\hline Guillemot & Winter visitor & Thames \\
\hline
\end{tabular}




\section{THE PEREGRINE FALCON}

\section{FALCO PEREGRINUS}

Local names in surrounding counties:

Status in British Avifauna: Local resident in the wildest districts; chiefly on the rock-bound coasts of England and Wales, but in Scotland and Ireland more generally dispersed. Its numbers are increased by migrants in autumn and spring, at which seasons and during the intervening months it is given to much wandering.

Radial Distribution within fifteen miles of $\mathrm{S}_{\mathrm{T}}$. Paul's: 'This species, the largest of British Falcons, can only be described as a rare and irregular visitor within London's limits. There are, however, plenty of records within the fifteen-mile area of this bold and handsome bird's visits to the Metropolis, induced doubtless by the flocks of Pigeons that haunt so many public buildings. There can also be little doubt that the bird pays many a fleeting call without being recognised. It is recorded that a pair of Peregrines once frequented St. Paul's, and were even thought to have bred there; whilst the bird has been seen to strike Pigeons in the London streets. It has frequently been killed in many suburban localitiesHampstead, Finchley, Highgate, Harrow-and at various places in Essex, Kent, and Surrey. The examples observed are usually in immature plumage, and most frequently occur in autumn and winter. I note recent records from Cheam and Sutton.

The normal haunts of this beautiful Falcon are remote from cities, in the wildest districts, especially along the rock-bound coasts, where towering headlands fling back the angry, turbulent waves that beat upon their face incessantly, and where rabbits and Sea-fowl afford it an abundance of food. Pigeons are everywhere a favourite quarry, and the colonies of Doves in our towns and cities I 2 


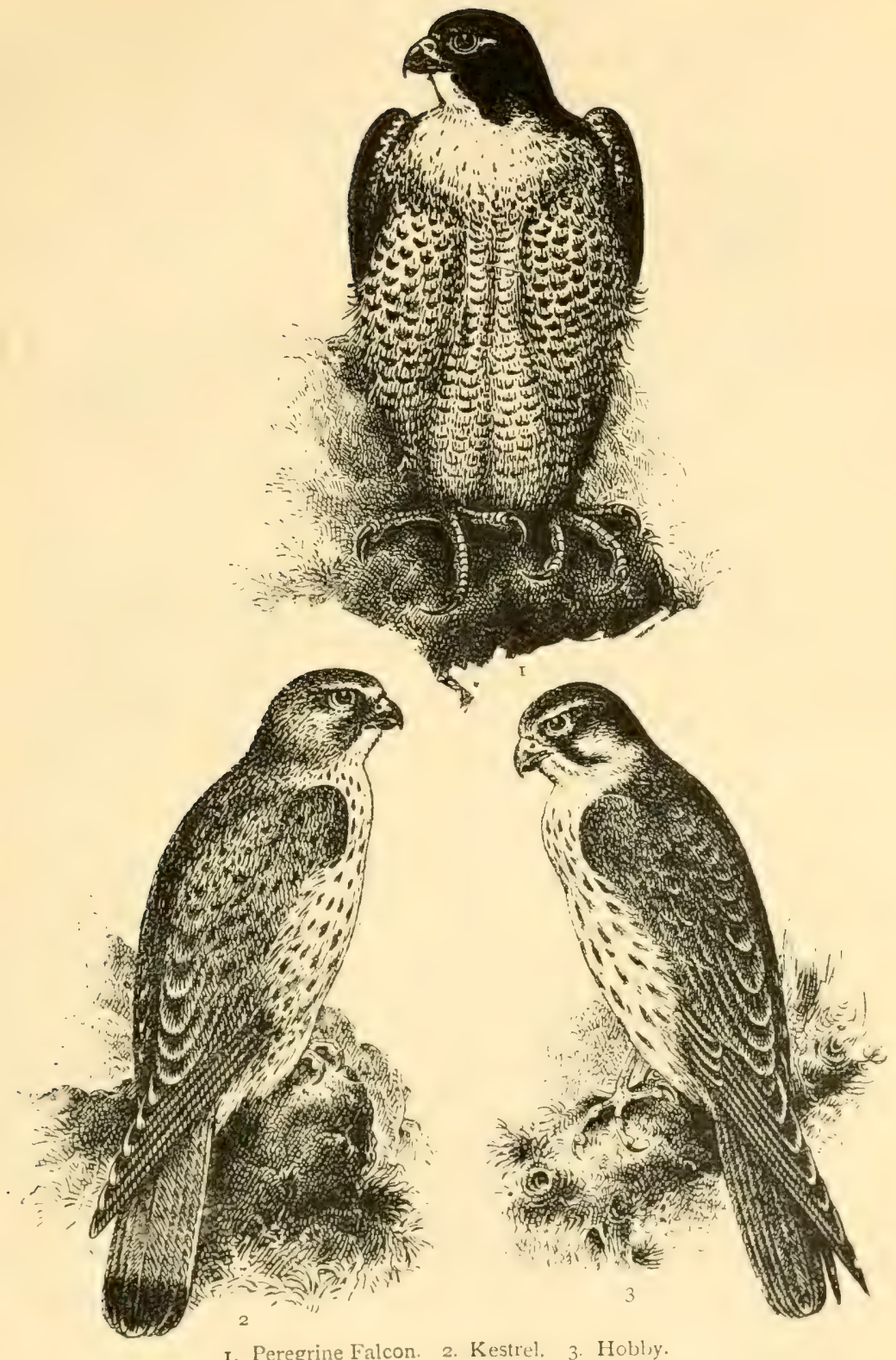





\section{THE PEREGRINE FALCON}

tcmpt it to visit such places in its annual wanderings. 'This bird is excelled by few other Raptores in the wild, swift swoop with which it strike sitsprey, its long, pointed wings giving it a superb supremacy in the air. It captures the various Game Birds, besides Ducks and Waterfowl of all kinds, Pigeons and rabbits, with almost matchless daring and dash. The bird probably pairs for life, returning each year to one particular place, and often selecting for its purpose some cliffs which teem with Seabirds. Herc, in April, on some narrow ledge or in a fissure, the three or four eggs are deposited in a slight depression, with little or no nest beyond the refuse of the bird's food. These eggs are dull white in ground colour, which, however, is mostly hidden by the profusion of reddish brown markings. As a rule the Peregrine is silent, but when its nest is disturbed it utters a most persistent chattering cry. When the young are reared the more or less wandering life is resumed, and the offspring rarely if ever remain in the locality of their birth. In all cases the Peregrine prefers an open haunt. It shows no liking for woods, choosing the breezy moors and uplands, from which a wide survey of country can be made, and where from some lofty perch it can start forth in quest of prey.

Although the sexes of the Peregrine are practically alike in colour, the cock bird is considerably smaller than the hen. The upper parts are dark slate-grey, becoming black on the head, and two moustachial lines extending from the gape down the sides of the throat; the under surface is buffish white, spotted on the throat and breast and barred on the remainder with black. Immature birds are brown above, each feather with a rufous margin, and the under parts are streaked rather than spotted. In adults the cere and eyelids are yellow, in the young slate-grey. Bill dark horn-colour; tarsi and toes yellow; irides dark brown. Length of adult male about 15 inches; female 17 or 18 inches. 


\section{THE HOBBY \\ FALCO SUBBUTEO}

LOCAI names in surrounding counties :

Status in British Avifauna: Arare and local summer visitor to England; seen on migration in Scotland and Ireland.

Radial Distribution within fifteen miles of $\mathrm{S}_{\mathrm{T}}$. PAUL's: The more or less regular appearance in spring of the Hobby in localities within the Metropolitan radius seems to suggest that in former years it bred in some numbers in the extensive woods that surround London. This pretty bird, a Peregrine in miniature, is seldom allowed to rear a brood in the surrounding counties nowadays, being shot or trapped and its nest pillaged at every opportunity. It has, however, been known to have bred successfully near London within the past twenty years, and would probably do so regularly if protected. As a casual visitor it is usually observed in April and May or September and October, when on spring and autumn migration. I have seen the Hobby in localities as far apart as St. Mary Cray, Epping Forest, and Wembley Park.

Although the Hobby is a miniature Peregrine in appearance its haunts are very different ones. It is essentially a woodland bird, but otherwise somewhat closely resembles its larger congener in its ways of life. In one respect, however, it differs very considerably from the Peregrine. It is a migrant, arriving late in April or early in May, and taking up its abode for the summer in large woods and plantations, from which it sallies in quest of food. Being probably a life-paired bird, it returns usually to the same haunts each year. It is quite as dashing and fearless in quest of prey as the Peregrine, but its quarry, of course, is smaller, chiefly consisting of the lesser birds, 


\section{THE HOBBY}

say up to the size of a Missel-Thrush. It also feeds largely on cockchafers and other large insects, hawking for them with remarkable dexterity. Like its ally it usually sits motionless on a lofty perch, whence it dashes as some bird or insect appears, but if the quarry is missed a second effort is seldom made. Like the Flycatcher, it prefers the borders of the woods or some isolated tree in the fields which commands a good view, when feeding, but at other times the shades of the forest are sought. This pretty Falcon makes no nest, but rears its young in the deserted cradle of some other bird. That of a Crow or a Magpie is frequently selected for this purpose, and here from threc to five reddish brown eggs are laid in June. If disturbed at the nest the old birds utter a tremulous chatter, showing considerable solicitude, but otherwise are comparatively silent. As soon as the young are strong upon the wing the place is deserted and the migration south takes place in September.

The male Hobby is dark slate-grey, almost black above, with two moustachial lines of the same colour, and the tail is barred with rufous brown; the under parts are very pale rufous, with brown streaks on the breast and flanks; whilst the thighs and under tail-coverts are chestnut. The female, larger than her mate, is not so bright in colour, and the streaks on the under parts are broader. Immature birds closely resemble young Peregrines, but are, of course, smaller. Bill horn-colour, cere yellow; tarsi and toes yellow; claws black; irides dark brown. Length of adult male nearly $\mathbf{2} 2$ inches; female nearly $\mathbf{I}_{4}$ inches. 


\section{THE KESTREL \\ FALCO TINNUNCULUS}

Local names in surrounding counties: "Hoverer" (Essex).

Status in British Avifauna: Common resident in the south; more or less migratory in the northern areas.

Radial Distribution within fifteen miles of St. Paul's: The Kestrel is certainly the commonest raptorial bird in the Metropolitan area, and there are few districts indeed in the suburbs where it may not be seen at some time of the year or another. It breeds regularly in all suitable spots in the outer portions of our fifteenmile circle, though unfortunately on the decrease in many localities. A hovering Kestrel is by no means an uncommon sight above such spots as Hyde Park, Kensington Gardens, Regent's Park, Greenwich Park, Clapham Common, and Battersea Park; whilst even yet more frequently it may be observed further afield at Tooting, Wimbledon, Richmond, Kew, Osterley Park, Hanwell, Acton, Ealing, Wembley, Sudbury, Finchley, Hampstead, Highgate, and Wanstead. Beyond these limits, again, the bird becomes of more frequent occurrence, a feature in the landscape that the bird-lover may expect to notice anywhere and at any time; whilst, on the other hand, the observant watcher from the crowded streets of the great city itself may from time to time detect the "Windhover" poised as if hanging from some invisible thread high above the loftiest buildings, or progressing across the great hive of toiling humanity below to more congenial haunts in the green country beyond. It has bred on the steeple of Bow Church in Cheapside, and on the Nelson Column in Trafalgar Square.

The presence of the Kestrel gives a pleasant touch of I6 


\section{THE KESTREL}

life to many a rural spot in the suburbs of London. Unlike the two preceding species, this little Falcon spends a good deal of its time in the air, flying about above the open fields and commons. It may easily be recognised by its flight. One moment it looks as if it were suspended from the sky, as it poises all aquiver with wings and long tail outspread; the next it is progressing with rapid-beating wings for a few yards; then the hovering actions are repeated, or the bird glides some distance with no apparent effort. Field after field is crossed in this way, interrupted, perhaps, by a sudden drop or swoop to the ground to capture prey, or an occasional visit to some tree to rest. There are few more harmless birds than the Kestrel, Its food consists chiefly of mice and coleopterous insects, cockchafers especially. It may capture an occasional small bird, but very exceptionally. There are few prettier sights in the air than a Kestrel engaged in hawking for cockchafers, these, as well as all other prey, being seized by the claws alone. 'The other smaller mammals are also captured. The Kestrel for the most part of the year is comparatively silent, but in spring it becomes garrulous, and may then frequently be heard uttering a chattering cry. This Falcon makes no nest, but takes possession of an old home of a Magpie or a Crow or seeks some hole in a cliff or building, and here it lays, in April or May, from four to six reddish brown eggs. As incubation progresses these become surrounded by pellets of cast-up food refuse, as is the manner of all Raptorial birds.

The male Kestrel is brighter coloured than the female, and has the head, neck, lower back, and tail grey, the rest of the upper parts rich reddish chestnut, spotted with black; the tail is tipped with white and broadly barred with black near the tip; the wings are dark brown; the under parts are pale buff, darkest on the breast, marked with dark brown. Bill blue, yellow at 


\section{THE BIRD-LIFE OF LONDON}

the base ; cere, orbits, tarsi, and toes yellow; claws black. The female has the entire upper parts chestnut barred with black, and the under parts are much more streaked. Length of adult male about 12 inches; female about I $2 \frac{\pi}{2}$ inches. Young birds in first plumage resemble the female. 


\section{THE SPARROW-HAWK}

\section{ACCIPITER NISUS}

Local names in surrounding counties:

Status in British Avifauna: A widely distributed resident.

Radial Distribution within fifteen miles of $\mathrm{S}$ t. Paul's: The Sparrow-Hawk is much less rarely met with in the inner suburbs than the preceding species, possibly because it is not so aerial in its habits. It is a casual visitor to some of the London parks and commons, and certainly breeds at many places well within the fifteenmile radius, as, for instance, in the Wimbledon and Richmond districts, about Hanwell, Sudbury, Wembley, Barnet, Enfield, Epping, Wanstead, the Kentish Crays, Ewell, and Epsom. In most districts the bird seems to be on the decrease, owing to the persecution of gamekeepers and to the encroachments of the builder. I have seen this Hawk in Hyde Park, in Regent's Park close to the Zoological Gardens, and more frequently in the vicinity of Neasden and Dollis Hill. As one gets further into the rural and well-timbered districts its appearance, of course, becomes more frequent; although even in the heart of the country these Hawks are nowhere numerous, and a sight of them is only obtained at irregular and uncertain intervals. They are solitary birds, and thinly distributed everywhere.

For its size, the Sparrow-Hawk is one of the boldest and most rapacious of the Birds of Prey. It delights in well-timbered localities, woods and fields with tall hedges and plenty of trees about them. Although its wings are somewhat short and rounded it is capable of rapid flight, seen at its best when the bird is following some victim. It may often be met with gliding along the hedgeside in quest of prey, and with a sudden, lightning-like swoop 


\section{THE BIRD-LIFE OF LONDON}

seize some unsuspecting small bird sitting quietly on a spray, or as suddenly drop to the ground and strike a terror-stricken victim there. This Hawk is the terror of the countryside, the dread of all the smaller birds, and the captor of many species much larger and heavier than itself. Frogs, field-mice, rats, and young rabbits are also taken. The Sparrow-Hawk always builds its own nest-a large, flat structure, usually placed on a branch close to the trunk in a tall tree, a fir or pine for preference, and made of sticks, some of them with green buds attached. Here in April or May the female lays four to six very pretty eggs, pale greenish blue, handsomely splashed and spotted with reddish brown, pale brown, and grey. Very often these markings chiefly form an irregular zone round one end. Both parents incubate, and when the young are hatched the old birds become even more rapacious, ceaseless in their hunting for prey. The female especially sits very closely, often remaining on the nest until the climber reaches it. She is also very bold in its defence, swooping past the intruder's head, whilst the male, high in the air above, sails round and round in circles anxiously awaiting events.

The male Sparrow-Hawk is dark slate-grey above, with a white patch on the nape; the wings and tail are brown, the latter barred with darker brown; the under parts are rufous brown, palest on the throat and under tail-coverts, barred with a darker tint of the same. The female, which is nearly twice the size, has the upper parts brown, relieved with a similar pale nuchal patch, and the under parts greyish white barred with brown. 'The young in first plumage vary considerably in colour even in the same nest, but resemble the female in a general way, although the upper parts are marked with reddish brown. Bill bluish horn; cere, tarsi, and toes yellow; claws black; irides yellow. Length of adult male about 13 inches; adult females 2 to 3 inches longer. 

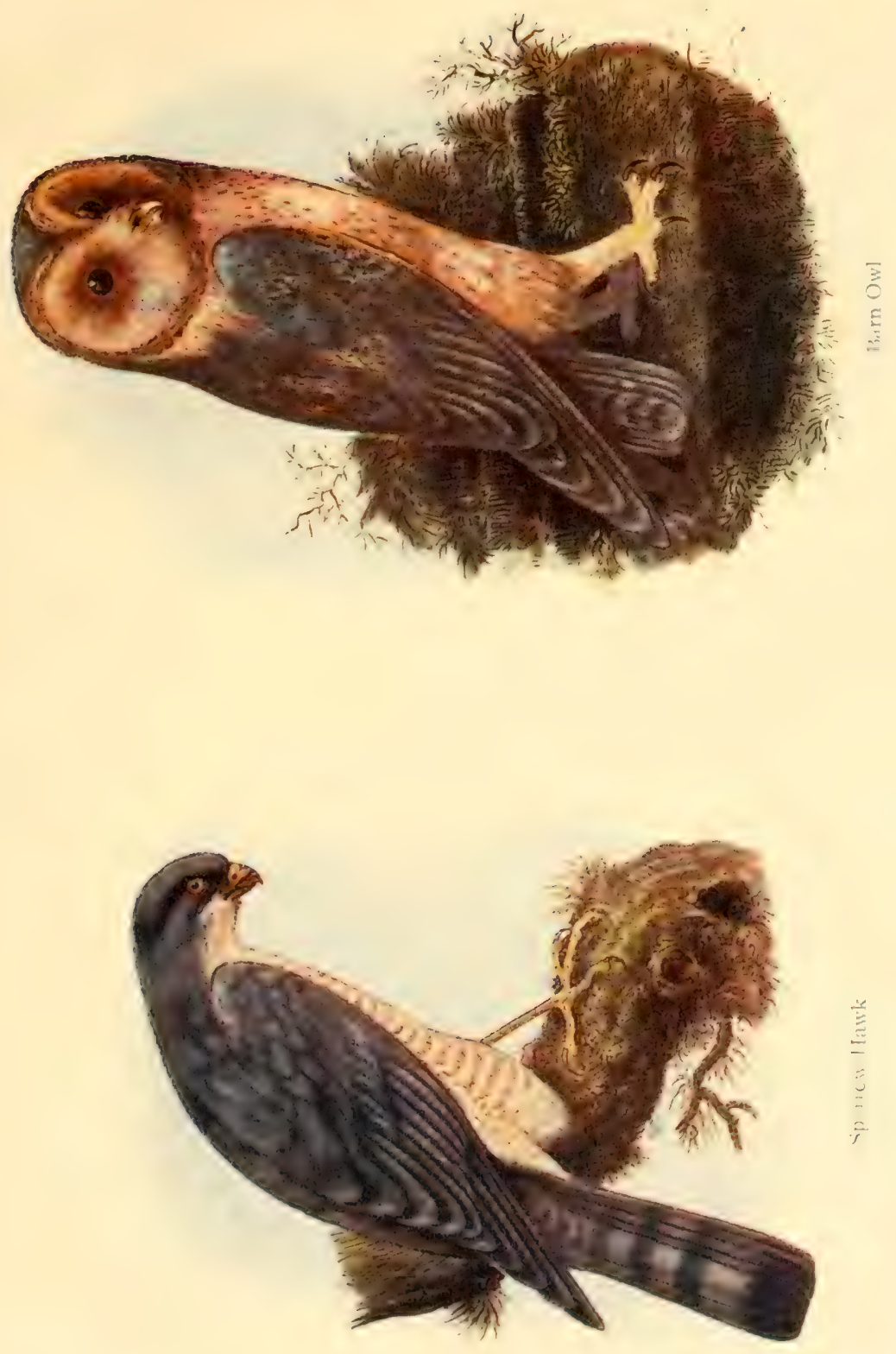



\section{THE BARN OWL}

\section{STRIX FLAMMEA}

Local names in surrounding counties: "White Owl." "Willy," "Billy Owl" (Essex).

Status in British Avifauna: A widely distributed resident, becoming scarcer and more local in the wilder districts.

Radial Distribution within fifteen miles of $\mathrm{S}_{\mathrm{t}}$. PAul's: 'The Barn Owl is by no means a rare bird in the more rural parts of the Metropolitan radius. I have found it, so far as my experience goes, most common in Surrey and Middlesex, but other observers testify to its by no means unusual occurrence in Essex and Kent. I have never heard its cry in any of the inner London parks, nor do I know of any haunt of this Owl within the five-mile radius. Beyond that limit, however, there are many places where the note of the Barn Owl is a fairly familiar night-sound, and as we pass mile after mile outwards into the remoter suburbs and the opening countryside the species becomes more frequent. It still haunts Harlesden, and occasionally the open country near to Kensal Rise.

If left unmolested there can be little doubt that the Barn Owl would eventually become commoner than it is now in the immediate vicinity of London. It readily makes any old barn, hollow tree, or church-tower into a resort, whence it sallies forth at nightfall in quest of food. It is seldom seen abroad before the twilight hour, and from then until dawn it is actively engaged in searching for food, which largely consists of mice. It will regularly catch thirty or forty of these troublesome vermin in a single night, so that its usefulness to man is great. It is, indeed, one of the farmer's best friends, and should receive far more encouragement and protection than it usually 


\section{THE BIRD-LIFE OF LONDON}

gets. Besides mice it also preys upon rats, moles, shrews, and even occasionally on fishes. The flight of this Owl is graceful, airy, and noiseless, and in course of feeding the bird will quarter almost every foot of field after field, flitting to and fro in a very ghost-like way. The startling, unearthly note of the Barn Owl-a wild screech-is too well known to require more than the barest allusion; besides this it utters a snoring note. This Owl, like the House Sparrow, begins to breed carly in spring, and continues to rear brood after brood all the summer. It makes no nest, but lays from three to six white eggs, rough in texture, and about as big as those of a Pigeon. These are deposited on the bare floor of the hole or on the pellets of food refuse cast up by the parents, the cavity selected usually being the day retreat. The first eggs are laid in April or May, and clutches are produced until quite late in the autumn. Many readers may be familiar with the snoring cry made by the Owlets, but this noise is not entirely confined to the young.

The Barn Owl has the general colour of the upper parts sandy buff, vermiculated with grey and finely spotted with black and white; the wings and tail barred with brown; the pear-shaped face surrounded by a frill of stiff plumes; and the under parts generally are white in the male, but sparsely spotted with dark brown on the flanks in the female. In some examples the breast is suffused with rufous. Bill pale yellow; feet covered with stiff hairs; claws black; irides black. Length of adult about I 3 inches. The young are clothed in white down. 


\section{THE TAWNY OWL}

\section{SYRNIUM ALUCO}

Local names in surrounding counties: "Brown Owl" (Essex).

Status in British Avifauna: Fairly common resident in the wooded areas of England, Wales, and the south of Scotland, but unknown in Ireland.

Radial Distribution within fifteen miles of $\mathrm{S}_{\text {t. }}$. Paul', : The Tawny Owl, I should say, is a rarer bird within the Metropolitan limits than the preceding species, although I have heard it very frequently no further away from St. Paul's than Harlesden, and it is said even to breed in Kensington Gardens. It may also often be heard at Wembley, and is known to frequent the vicinity of Dulwich, Wimbledon, Richmond, Bushey, Kew, Osterley, Hampstead, Epping, and Wanstead. Further afield, of course, it becomes more numerous, and is locally distributed in most of the wooded districts within our Metropolitan radius of fifteen miles. Owls are most difficult birds to observe, and during their seasons of silence can very easily be overlooked. They frequent regularly many localities where their presence is not even suspected, and include in their nightly wanderings many places far from their roosting- and breedingplaces.

The melancholy, decp, and far-sounding cry of the Tawny Owl is a very familiar night-cry in the wooded districts of suburban London. At such places as Richmond Park, Epping Forest, and Osterley, to go no further afield, the oft-repeated boo-wbo-boo of this Owl may be heard during the livelong summer night. The Tawny Owl shows no partiality for buildings; it loves the woods, and usually makes its retreat in some hollow tree, although it occasionally passes the day sitting on a branch asleep 


\section{THE BIRD-LIFE OF I.ONDON}

with its body pressed close up to the trunk. If disturbed the light seems to cause it uneasiness, and it glides off on silent wings in an crratic, uncertain way, its only aim, apparently, to find another dusky nook. It is thoroughly nocturnal, heard but seldom seen, and seeks its prey in darkness. This food consists chicfly of mice, rats, voles, shrews, young rabbits, and frogs, all the indigestible parts of which are thrown up in pellets. Small birds are occasionally caught. During winter the 'Tawny Owl is somewhat solitary, but at other times lives in closer company with its mate, to which it is apparently paired for life. The same retreat and nestingplace is often used year after year. It makes no nest, but lays its three or four rotund white eggs in a hole in a tree or cliff, amongst a dense cluster of ivy, or even in the deserted home of a Crow, a Magpie, or a squirrel. The first clutch of eggs is usually laid in March, and succeeding clutches are produced as late as August. The birds resent any disturbance, and are frequently very fearless when "their young are approached.

The general colour of the upper parts of the Tawny Owl is chestnut-brown, vermiculated and spotted with dark brown and black; the wing-coverts are marked with round white spots; the under parts are buff, streaked and barred with brown. The female is a trifle larger than the male. Bill greyish yellow; irides dark brown. Length of adult between 15 and 16 inches. The nestling is clothed in greyish white down. 


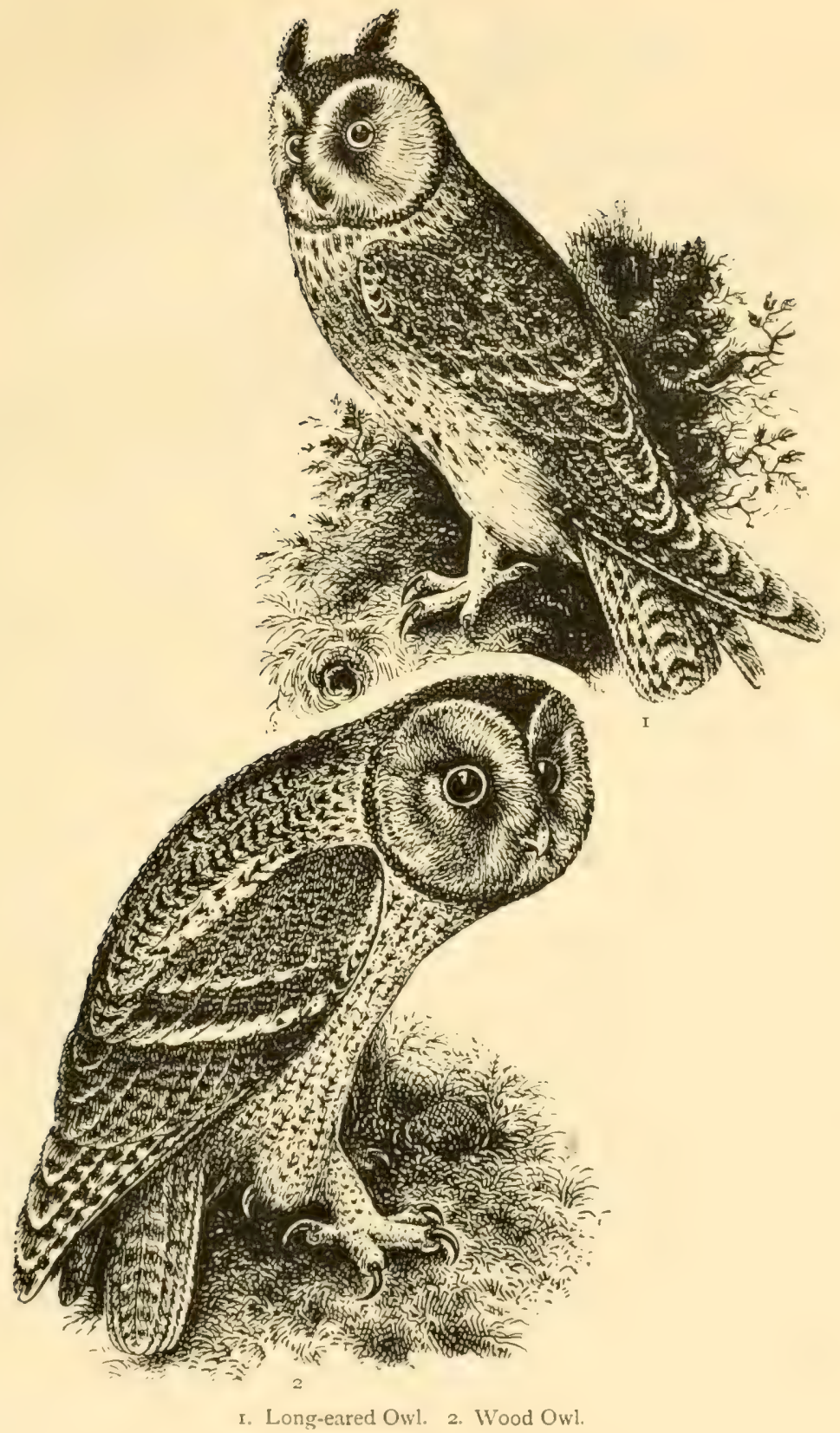





\section{THE LONG-EARED OWL, \\ ASIO OTUS}

Local names in surrounding counties:

Status in British Avifauna: A widely distributed resident, its numbers increased in autumn by migratory individuals.

Radial Distribution within fifteen miles of $\mathrm{S}_{\mathrm{t}}$. PAUL'S: 'The present species is certainly the rarest and the most local of the Owls to be met with in the Metropolitan area. Possibly the absence of dense fir-woods and other suitable haunts may be the reason. I know of no regular resort of this Owl within eight miles of St. Paul's, but it may possibly breed at Wembley and Pinner in the north-west, in the Bushey district, and in the Crays in the south. I know of no Essex resort. Just beyond our limits this Owl certainly breeds at Windsor, Burnham, and Farnham, and also near Uxbridge.

It is with some diffidence that I include the Longeared Owl in the present work, and I do so chiefly because there is a strong possibility of the bird being overlooked in many of the outlying districts well within the fifteenmile radius. Pine- and fir-woods are the favourite haunts of this Owl, and where it does occur several pairs not unfrequently resort to the same neighbourhood. In its habits it very closely resembles the Tawny Owl. It is just as nocturnal and retiring, passing the day in some dark, secluded spot amongst ivy, in a hole in a tree, or in the dark crown of a pine. It also has the same habit as the Tawny Owl of sleeping whilst pressed close up to the trunk of a tree, where its beautifully mottled plumage so closely resembles the bark that detection is difficult. The approach of twilight arouses the Long-eared Owl into activity, and it comes forth into the open in quest of food. In soft and noiseless flight it quarters the 


\section{THE BIRD-LIFE OF LONDON}

neighbouring fields and commons, pays visits to the rickyards, and I have known it to pass to and fro above the highway. This Owl neither hoots nor screeches, but utters a mewing or barking cry. It apparently pairs for life, and keeps fairly close to one particular haunt throughout the year. It is an early breeder, laying its eggs from February onwards. No nest is provided for them, and they are deposited in the old deserted home of a Pigeon, Crow, Magpie, or squirrel, or in some hollow in a tree, especially where ivy grows in dense festoons and bunches. They are from three to seven in number, white, and slightly polished. The chief food of this Owl consists of mice, rats, and voles, but small birds and insects are occasionally sought.

The general colour of the upper parts of this Owl is buff, mottled and vermiculated with various shades of brown; the long horns or erectile tufts are black marked with buff; the under parts are of a paler buff, streaked with dark brown and barred with light brown. Bill and claws bluish grey; irides bright orange-yellow. Length of adult between I 3 and $\mathbf{I} 4$ inches. The nestling is covered with grey and buff down. 


\section{THE BLACKBIRD}

\section{MERULA VULGARIS}

LOCAL names in surrounding counties:

Status in British Avifauna : A common and widely distributed resident, and increasing its range in many localities.

Radial Distribution within fifteen miles of St. Paul's: The Blackbird is almost as familiar in the London parks and gardens as the House Sparrow is in the crowded streets. It is a resident, and breeds regularly from less than a couple of miles from St. Paul's, in St. James's Park, in every spot sufficiently suitable to its needs, garden, park, and pleasure-ground, right out to our radial limits in the open country. Few are the private grounds, orchards, and open spaces where the noisy yet sweetvoiced songster may not be heard. I have frequently remarked its exceptional numbers about the orchards and gardens at Acton, Ealing, and Gunnersbury, also in Battersea Park; whilst its song, especially at morn and even, is a marked feature in such leafy suburbs as Dulwich and Clapham. In winter the bird may often be observed in the squares, fraternising with Starlings and Sparrows. I have seen it at this season in the Embankment Gardens between Charing Cross and the Temple, as well as in gardens near Euston Road. It is common in the Botanical Gardens, and I lately saw it at the Marble Arch.

One of the first signs of the advent of spring to dwellers in London is the Blackbird's resumption of song. In a fairly open season the bird regains his voice in February, and then the flute-like warble, all too short, and interrupted by intervals of silence, may be heard almost everywhere, wherever there is sufficient greenery to afford the sable songster shelter. His song, with that 


\section{THE BIRD-LIFE OF LONDON}

of the 'Thrush, forms the most familiar bird-music of rural London, and must recall to countless toilers in the Great City memories of green countrysides and distant homes, of younger and more peaceful days, free from the stress and turmoil that throbs unceasingly around them here. Amidst such scenes and surroundings the song of the Blackbird in London can never be more than an echo of the country. During April and May he keeps in splendid voice; there is a marked decrease in June; and in July it ceases for the year in the annual moult which then begins. Every reader must be familiar with the Blackbird, either as it hops fearlessly about the grass or scurries off into the evergreens startled and uttering a string of loud cries, lifting its long tail above its back just as it alights. It is pugnacious enough, and rarely allows another of the same sex to share its own particular haunt. This trait is specially marked in spring, when males may be seen in the London parks and elsewhere chasing each other amongst the shrubberies. The food of this species during spring and summer is largely composed of worms, grubs, slugs, and certain insects; in summer the bird levies a heavy toll upon the suburban fruit gardens; whilst in autumn and winter berries of many kinds are eaten. It pairs carly in spring, and may be found nesting from March onwards to August. The first nests of the season are usually made in an evergreen, but later on as deciduous trees come into leaf almost every kind of tree or bush is selected. In many of the London parks the nest will often be made within a few paces of frequented paths. It is composed of dry grass, twigs, dead leaves, and moss, lined first with mud and then with fine dry grass. 'The eggs are from four to six, greenish blue, spotted and freckled with reddish brown and grey. Both parents incubate; and if disturbed frequently utter a very plaintive note, something like the "weeping" cry of the Robin at the same season. 28 


\section{THE BLACKBIRD}

This Ouzel is not gregarious, and if seen in numbers together has congregated only where food chances to be abundant.

The adult male Blackbird is uniformly glossy black; the bill and orbits are orange-yellow. The female has the upper parts dark brown tinged with olive, darkest on the wings and tail, the under parts brown, more or less suffused with rufous on the throat and breast, which are marked with dusky streaks. Bill and orbits nearly black; legs and feet of both sexes nearly black; irides dark brown. Length about Io $\frac{\text { I }}{2}$ inches. Young in nestling plumage have pale shaft streaks and dark tips to the feathers of the upper parts, and the under parts have dark bars. 


\section{THE RING-OUZEL}

\section{MERULA TORQUATA}

Local names in surrounding counties:

Status in Britisin Avifauna: A regular summer visitor to the moors and uplands; lowlands on migration.

Radial Distribution within fifteen miles of $\mathrm{S}$ t. Paul's: London and the home counties generally scarcely come within the limits of the Ring-Ouzel's migration route to the northern districts of Great Britain, where the bird spends the summer. Nevertheless it has been known even to breed in Kent; whilst from time to time stragglers out of their normal course appear within the Metropolitan area. In Surrey the bird is by no means a very rare one on passage, especially on the higher grounds. In Middlesex it similarly occurs, and has been recorded from Kingsbury, Kilburn, Hampstead, Hendon and Edgware. It is seen occasionally in Essex, and quite recently an example was shot on the sewage farm at Walthamstow. Many years ago (in the autumn of 1889) I came across a small party of Ring-Ouzels, apparently a brood of the year, and their parents, close to Essom. They were feeding on berries of the mountain ash, on some open ground, and were comparatively tame. 'This was the first time I had seen the Ring-Ouzel away from its summer haunts on the moorlands, although I have many times met with it in gardens and orchards in the northern shires when passing south from its breeding places in autumn.

It is only a very flecting glimpse that the Londoner can ever hope to get of the Ring-Ouzel. 'This is when the bird is migrating to or from its summer home on the wild uplands and moors of the north. It travels in flocks of varying size, sometimes composed of a hundred or more individuals. It is a somewhat shy, yet on occasion bold 30 


\section{THE RING-OUZEL}

and very noisy, bird, resenting any intrusion of its haunt by a series of oft-repeated chattering cries. It visits our islands to breed, spending the winter in the sruth of Europe or North Africa. In its summer haunts it is particularly fond of irequenting rocky places, the banks of moorland streams, where heather and birch-trees are plentiful, and where the gorse and bramble and bracken are interspersed with huge boulders. Soon after arrival the males crommence their song, which is not so flute-like as that of the blackbird, although equally short and broken up by interrupted strings of harsh notes. It breeds in IIay, making a nest exactly similar to that of the Blackbird in a low bush or on the ground amongst the heath. The frour or five eggs also resemble those of that species so closely that they cannot be distinguished from them. At the nest it is very pugnacious. In its food, flight, habit of elevating its tail upon alighting, and in many other ways it closely resembles the more familiar bird. It rears but one brood each season, and retires south in September and October.

The adult male Ring-Ouzel is nearly uniform brownish black, except a broad white band across the breast, and most of the small feathers have pale margins. Bill yellow; tarsi and claws brown; irides brown. The female is duller and browner, and the white gorget is suffused with brown. Length about ro inches. Nestlings are barred with black and buff on the breast and back, and the wing coverts are spotted with buff. 


\section{THE FIELDFARE \\ TURDUS PILARIS}

Local names in surrounding counties: "Felfer," "Jack Bird" "Pigeon-Felt" (Essex).

Status in British Avifauna: A common and widely distributed winter visitor.

Radial Distribution within fifteen miles of St. PaUl's: The Fieldfare is by no means an uncommon winter migrant to the Metropolitan area, although, like everywhere else, its numbers vary a good deal almost every season in succession. This may not be altogether due to the local weather conditions in the British Islands, but to the fact of a successful breeding-season in the northern regions or the reverse. During hard weather this handsome Thrush may frequently be remarked in the parks and open spaces within a few miles of St. Paul's, whilst fleeting visits are often paid to many suburban gardens and pleasure-grounds, a plentiful supply of berries often proving the chief attraction. As we get out more into the opening country, into the comparative seclusion and quiet of the remoter suburbs, the Fieldfare is more frequently observed. So far as my own experiences go, these remarks specially refer to the Streatham, Norwood, Wimbledon, Richmond, Harrow, and Barnet districts. The bird, however, is well known in many others, especially in Essex, in the Epping area, and I have records of its abundance in some years in the Kentish Crays and many parts of northern Surrey. The Fieldfare, however, is everywhere a somewhat capricious visitor.

Unlike the Ring-Ouzel, the Fieldfare is a visitor to our shores in winter only, arriving early in November and leaving towards the end of March or beginning of April. It lives in flocks of varying size, which wander about the open country largely in quest of the berries upon which 32 

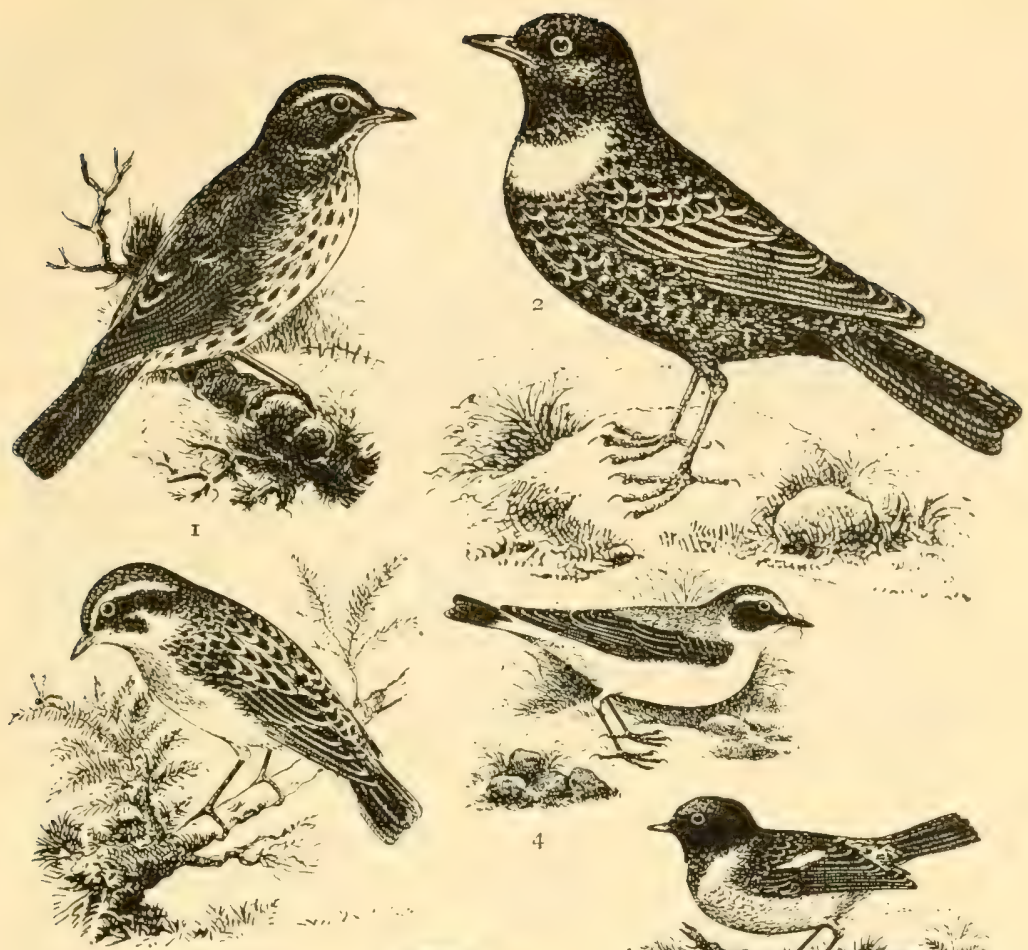

Fing
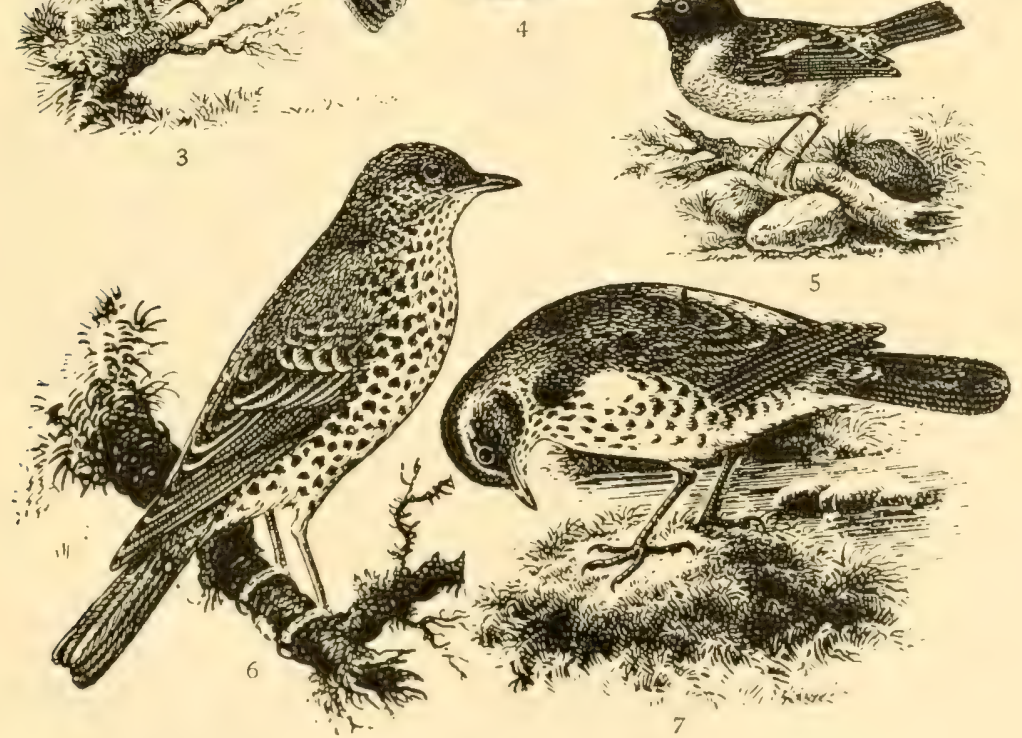

I. Redwing. 2. Ring-Ouzel. 3. Whinchat. 4. Wheatear. 5. Stonechat. 6. Missel-Thrush, 7. Fieldfare. 

it chiefly subsists during its stay with us. At night these flocks usually resort to some shrubbery to roost, continuing to do so as long as they remain in the locality. Next to the Missel-Thrush the Fieldfare is the wildest and the wariest of the British Thrushes. The flocks generally pass from place to place at a good height, and the birds may be readily recognised by the white under the wings, which is very conspicuous during flight, and also by their harsh notes of sack-sack. Beyond these harsh call-notes and a series of low guttural notes often heard at the roosting-place or when the birds are feeding, the Fieldfare is silent. Its song is reserved for the breeding season in the Arctic regions, where it nests. During its stay with us the bird is chiefly a berry-feeder, but in summer it subsists on animal substances and fruit. It breeds in scattered colonies, making a nest very similar to that of the Blackbird, and its five or six eggs so closely resemble those of that species that they cannot be distinguished.

The adult Fieldfare has the general colour of the upper parts slate-grey, spotted on the head with black, and the back is chestnut-brown. The wings and tail are brownish black; the throat and breast are buffish brown; the centre of the abdomen and the axillaries are white; the throat and breast have black streaks, and the buff flanks are mottled with black. Bill yellow; tarsi and toes black; irides brown. Length about roinches. The nestling is spotted on the upper parts. 


\section{THE REDWING \\ TURDUS ILIACUS}

Local names in surrounding counties:

Status in British Avifauna: A common and widely distributed winter visitor.

Radial Distribution within fifteen miles of St. PAUL's: The Redwing seems everywhere to be a more abundant bird than the Fieldfare, although almost precisely the same remarks apply to its distribution in the Metropolitan area otherwise. It is also much more regular in its habits, and returns to certain spots each autumn, which it makes its headquarters and roostingplaces all the winter through. Not only so, but the Redwing is more gregarious. Fieldfares are often met with in scattered parties; Redwings as frequently live in large flocks; and as they obtain the bulk of their food upon the ground many open localities are resorted to which would have little attraction for the Fieldfare, which depends so largely for sustenance upon berries. There are many acres of market gardens and open fields scattered about the suburbs where this Thrush congregates in large numbers. I have also seen it repeatedly in the WestEnd parks-St. James's Park, Hyde Park, and Kensington Gardens especially - and a fall of snow has always a tendency to drive it townwards. In the remoter suburbs it is, of course, much more frequently observed. It is exceptionally common in the Epping area and in the Walthamstow and Wanstead districts. Severe winters often send it to unusual localities.

There are certain characteristics in the appearance and economy of the Redwing that serve readily to distinguish it from the Song Thrush, which it not only closely resembles, but with which it is very often confused. The Redwing is perceptibly smaller, has a pale stripe 34 


\section{THE REDWING}

above the eye, dark ear-coverts, and the flanks and under surface of the wings are bright chestnut. Then it only appears in our islands in winter, and is a very gregarious bird. Bands of Redwings reach us in October, a little earlier than the Fieldfare, and in many cases return each season to certain haunts, which they frequent throughout their stay. They are much attached to a roosting-place - usually in some shrubbery or wood with plenty of undergrowth containing evergreens. The days are spent chiefly upon the fields, where the birds may be seen constantly in motion, the flock scattering in all directions, individuals every now and then taking short flights; and if disturbed the whole band rises irregularly and congregates upon some tree, whence as the alarm subsides they fly down to the grass again in twos and threes to resume their search for food. The Redwing is not so much of a berry-feeder as the Fieldfare, subsisting chiefly upon worms and other animal substances. It suffers severely during a long-continued frost in consequence. The bird is silent, so far as song is concerned, in our country, its usual note being a shrill yelp or a musical double note during flight; it also utters a harsh chattering cry similar to that of the Song Thrush when alarmed, and at the roosting-place a low and not unpleasant chatter. The Redwing breeds in more or less scattered colonies, in birch-and alder-trees, and its nest very closely resembles that of the Blackbird. Its four or five eggs resemble those of that species, but are much smaller.

The adult Redwing has the general colour of the upper parts olive-brown; the eye-stripe is very pale buff. The under parts are pale buff, shading into white on the abdomen and into bright chestnut on the flanks; under wingcoverts and axillaries spotted and streaked with dark brown. Bill dark brown; tarsi and toes pale brown; irides brown. Length about 8 inches. The nestling is spotted both on the upper and under parts. 


\title{
THE SONG THRUSH
}

\author{
TURDUS MUSICUS
}

Local names in surrounding counties: "Mavis" (Essex).

Status in British Avifauna : A common and widely distributed resident, subject to some local migration, and its numbers perceptibly increased in autumn in certain districts.

Radial Distribution within fifteen miles of St. PAul's: The present species is unquestionably the commonest and most generally dispersed Metropolitan Thrush. From the two-mile radius, which includes part of the Green Park and the whole of St. James's Park, the Song 'Thrush may be found in numbers that only vary in response to the suitability of its haunt. To give its distribution in detail here would require a page or more merely to list the names of almost every open space sufficiently covered with trees and undergrowth to afford it cover. There are few places it frequents in which it does not habitually nest, and I have often remarked its home in some evergreen tree in the most frequented spots. As the suburban circle widens the Song Thrush increases in numbers. It is a bird that Londoners should dearly prize, for it voices in unstinted abundance one of the sweetest and the most charming echoes of the countryside. I have stood in Trafalgar Square in the quiet of a springtide dawn listening enthralled to the varied notes of this loud-songed chorister, wafted over the grimy roofs of Spring Gardens from the plane-trees in St. James's Park. In a few hours the roar of the traffic conceals the music, but the song goes on just the same the livelong day.

Town life has modified the habits of the Song Thrush but little; and it is this fact that renders the bird's 36 


\section{THE SONG THRUSH}

presence in the Metropolis all the more attractive and gratifying. It is perhaps the most persistent songster of all the London birds, continuing in voice, if fitfully, nearly the winter through, commencing its almost endlessly varying lay at dawn, and continuing until darkness has settled over its haunts. In April and May especially its voice lends quite a rural charm to the more central London parks, and the song is all the more lustily given after rain. The tired and perhaps miserably hopeless wayfarer may turn aside from the turmoil of the streets into these lovely sylvan spots and be soothed by the cheery voice of the Throstle, and his fancy may interpret into messages of hope and encouragement the varied notes of this speckled songster. There are few more familiar birds than the Song Thrush, and it readily responds to any advances that may be made for its protection and comfort. There must be few readers who have not watched this bird hop out from under the evergreens on to the grass and then pause a moment as if listening intently, then, perhaps, run or hop a little way further into the open and make another pause, presently seizing a worm and dragging it out to eat it at leisure. Most of the grass is searched, and every now and then another struggling worm secured. It also searches for snails, breaking the shells by striking them against a stone or the hard ground; grubs, fruit, and berries are also eaten. Many Thrushes may often be remarked feeding within a small area, but the bird is by no means a gregarious one. 'The Song Thrush is not a very noisy bird, but often at nightfall, or when disturbed at the nest, it becomes garrulous, especially when the young "are hatched, its cries on these occasions being very loud and harsh. It pairs early in the year, and its nest may frequently be found in February; March and $\Lambda$ pril are the more regular months. It will build in almost any bush-an evergreen for preference in early spring-or low tree, no pains being 


\section{THE BIRD-LIFE OF LONDON}

taken to conceal it. It is made of dry grass chiefly, mixed with roots, dead leaves, moss, and sometimes a few twigs, lined first with wet mud, and finally with wet decayed wood. The eggs are four or five in number, turquoise blue, spotted with very dark brown and grey. Both sexes incubate, and frequently several broods are reared in the season. To some extent this Thrush is migratory, leaving certain districts entirely during winter, a fact attributable probably to its animal diet, for like the Redwing it shows small partiality for berries.

'The adult Song Thrush has the general colour of the upper parts olive-brown, the wing-coverts tipped with buff; the under parts are white, more or less suffused with pale buff, most pronounced on the flanks and breast ; the under surface of the wings is golden buff; most of the under surface is spotted with black. Bill dark brown, paler at the base of the lower mandible; tarsi and toes yellowish brown; irides brown. Length about 9 inches. 'The nestling is profusely mottled and spotted on the upper parts with buff. 


\section{THE MISSEL-THRUSH.}

\section{TURDUS VISCIVORUS}

Local names in surrounding countics: "Mavis," shared in common with the Song Thrush.

Status in British Avifauna: A widely distributed resident in all wooded districts, and one that has greatly increased its range during the past century. Its numbers are increased in autumn by migratory individuals.

Radial Distribution within fifteen miles of $\mathrm{S}_{\mathrm{t}}$. PAUL'S: The gratifying improvement of late years in the protection of birds within the London area, resulting so beneficially to many species, seems not to have affected the Missel-Thrush so much as other songsters that could be named. The fact is that the Missel-Thrush is not only very shy, but very wild. He is a countryman of pronounced type, not to be seduced by the many attractions of city life, and it is only in winter that he enters the inner circles of the Metropolitan area, driven thereto by need. In the outer suburbs, however, the bird is much more generally distributed, breeding in many localities and paying fleeting visits to others with tolerable regularity. I have heard its wild song in Regent's Park, in Kensington Gardens, and in Battersea Park, but have no proof that it breeds there, although said to doso. I know that it nests, however, in the Wimbledon and Richmond districts, and at Osterley, Twyford, Harlesden, Wembley, Dollis Hill, Hampstead, Epping, and Wanstead. As we leave the more central districts it becomes commoner, and in surrounding areas, well within the fifteen-mile radius, it is a widely dispersed and well-known resident.

The Missel-'Thrush is not only the largest, but by far the wariest of the British Thrushes. It delights to frequent the tallest trees rather than the shrubs and underwood so dear to the Song Thrush, and when disturbed whilst 


\section{THE BIRD-LIFE OF LONDON}

feeding on the ground almost invariably seeks a refuge in the highest branches. It obtains much of its food on the ground, searching pastures, turnip-ficlds, and so forth for worms and grubs. It is also very partial to many kinds of berries and small fruits, roaming far and wide, especially in autumn and winter, in quest of them. In the matter of its music the Missel-'Thrush is unique among British birds. The song is commenced in autumn, continued through the winter, and ceases in April, just when the voices of other Thrushes are at their best. It is a loud, wild song, uttered in fitful snatches from the tree-tops, not quite so flute-like as the Blackbird's, but otherwise resembling it, and nothing nearly as varied as the 'Throstle's. 'The call-notes are harsh and grating, especially when the nest is disturbed. This Thrush pairs early in February, and a few weeks later nesting operations are in progress. 'The nest is built in tall trees, often in a fork or on a branch close to the stem, and less frequently at a lower elevation in a birch, hawthorn, or cven an evergreen. It is made of dry grass, sphagnum or other mosses, tufts of wool, and slender twigs, lined first with mud and then with a thick layer of fine grass. The eggs are normally four, bluish, greenish or reddish in ground colour, spotted and blotched with reddish brown and grey. Two broods are frequently reared in the season. As soon as the breeding season is over the Missel-'Thrush assembles into flocks, but as winter approaches these disband to a great extent. The bird is now exceptionally wild and wary, often consorting with Fieldfares, a marked change in its habits from the early spring months, when it frequently makes its nest quite close to houses and in much-frequented spots. In fact, the Missel-Thrush is an anomaly in many respects.

The adult Missel-Thrush has the general colour of the upper parts pale olive-brown; the under parts are dull white boldly spotted with dark brown; the outermost 40 


\section{'THE MISSEL-THRUSH}

tail-feathers are marked with dull white patches, and the axillaries are white. Bill dark brown; tarsi and toes pale brown; irides dark brown. Length between Io and I I inches. The nestling is marked with buff and black on the upper parts, as well as spotted below. 


\title{
THE ROBIN
}

\author{
ERITHACUS RUBECULA
}

LOCAL names in surrounding counties:

Status in British Avifauna: A common and widely distributed resident, its numbers increased during migration.

Radial Distribution within fifteen miles of $\mathrm{S}_{\text {t. }}$ PAUl's: The Robin is another common London bird, although one that is much more frequently seen in the inner Metropolitan area during winter than at other times, when it seems to retire to remoter districts to bring up its brood. It is in autumn, perhaps, when the universality of its distribution is most apparent. It may be met with in almost every spot where a wild bird can find shelter, from well within the two-mile radius to the uttermost limits of the circle we have selected, becoming commoner, of course, as the suburbs become more rural and vegetation more abundant. How near to St. Paul's it may breed is rather a difficult question to solve. It may possibly do so in the grounds of Buckingham Palace, in St. James's Park and Hyde Park, as well as in Battersea Park; that it does so at Clapham, Dulwich, Kilburn, Brondesbury, and Hampstead there can be no doubt; whilst further afield, at Tooting, Wimbledon, Chiswick, Gunnersbury, Acton, Harlesden, Highgate, Wanstead, and other suburbs, it becomes, of course, increasingly numerous. In winter there are few suitable suburban grounds and gardens where it may not be detected, whilst in exceptionally severe weather it visits localities where its presence may justly excite surprise.

Although the London suburbs are visited in autumn and winter by numbers of Robins that not only come in from the country districts round about, but even from Continental Europe, the "Cockney" individuals wander little from their usual retreats, nesting in them. Most $4^{2}$ 

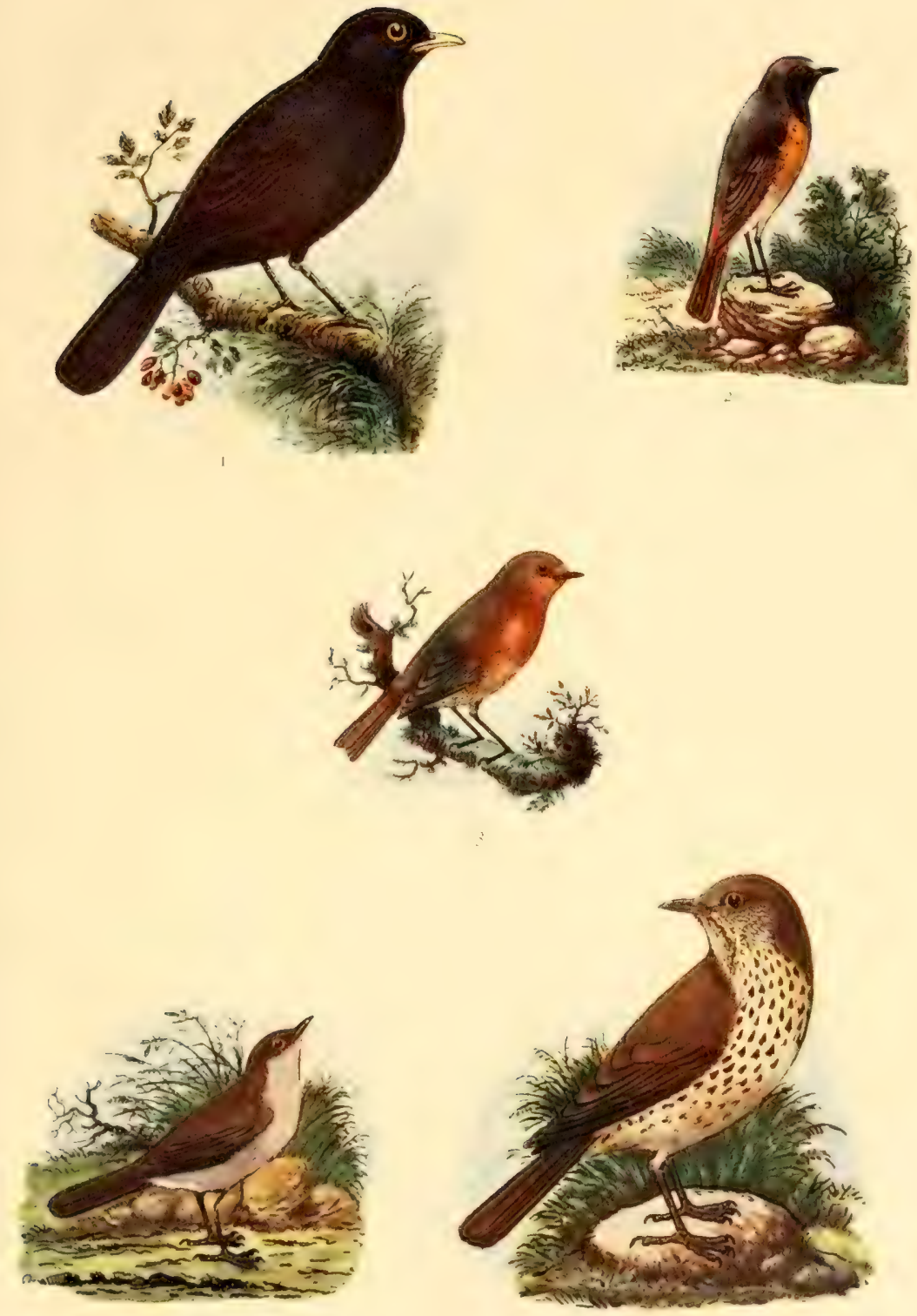

1. Blackbird. 2. Redstart. 3. Robiu. f. Nightingale. 5. Song Thrush. 



\section{THE ROBIN}

of the individuals seen in places where the species is not known to breed are either migrants or wanderers. 'The habits of the familiar Robin do not require to be described at any great length here. The bird is a prime favourite everywhere, and nowhere greater than in suburban London, where his charming song and trustful ways endear him to us. In many spots he is contented with the modest cover of a small garden or shrubbery, seeking a nesting-site in some retired corner; whilst in autumn his tuneful voice is almost the only bird-melody of suburbia. From August onwards the song becomes increasingly prevalent. The Robin is of solitary habit, resenting intrusion of its favourite haunt by other individuals of the species, and well able to hold its own with the Sparrow and other familiar birds. Its food chiefly consists of insects and worms, but in severe weather crumbs and other trifles scattered for our feathered pensioners are eagerly sought. The Robin is an early breeder, one of the first of the smaller birds to commence nest-building in March, or in exceptional cases even in February. As a rule the bulky nest is carefully hidden away in a hole of a wall, amongst ivy, or under a heap of wood or hedge-clippings, but many other situations are chosen, some of them most eccentric, as inside an old hat or can, on the shelf of a greenhouse or shed, or even in a flower-pot. It is made outside of moss, dry grass and roots, and dead leaves, the cup warmly and neatly lined with horsehair. Year after year the same situation will be used. The eggs, usually six in number, are white in ground colour, more or less thickly freckled and spotted with brownish red and grey. Most of the colouring-matter is usually dispersed over the large end of the egg, in a zone or circular patch. Both sexes incubate, and the sitting bird is often remarkably fearless. The young are tended for some time after they leave the nest, but eventually seek haunts elsewhere. 


\section{THE BIRD-LIFE OF LONDON}

The Robin is too familiar to require much detailed description. The adult is olive-brown, palest on the flanks, and almost white on the centre of the under parts; the forchead, throat, and breast are orange-chestnut, and the crown and sides of the neck are grey. Bill black; tarsi and toes pale brown; irides dark brown. Length $5 \frac{3}{4}$ inches. The young in first plumage lack all trace of the orange, and are spotted above and below with buff and black. 


\section{THE NIGHTINGALE}

\section{DAULIAS LUSCINIA}

Local names in surrounding counties:

Status in British Avifauna: A common yet local summer migrant to England east of Devon and as far north as Yorkshire; a straggler elsewhere.

Radial Distribution within fifteen miles of $\mathrm{S}$ t. PAUL's: The vast Metropolitan area is exceptionally well favoured by the Nightingale. Indeed, it is only the lack of suitable conditions, such as proper cover and food, that arrests its distribution short of the most central parts of London. There is abundant evidence to prove that almost within the memory of men still by no means aged the Nightingale regularly frequented spots now given up to the jerry-builder or the domain of squalor and wretchedness. Nightingale Lane at Clapham and Nightingale Road at Harlesden suggest Nightingales that are now no more. The vicinity of the Harrow Road near Kensal Rise was formerly a haunt. Here, as many readers know, Harrison Ainsworth once resided, and we have it on record that his house was a favourite meeting-place of Dickens, Thackeray, and other prominent men in literature, and that these kindred spirits used to walk along the Harrow Road and listen to the Nightingales after their convivial gatherings had dispersed. There are no Nightingales here nowadays, and the Harrow Road, depressing to a degree, is one of the meanest of London's many " mean streets," promenaded by Kensal Green-bound funcrals, and presenting countless evidences of squalor and poverty. 'There are many other localities in the Metropolitan area from which the builder has banished the Nightingale, but fortunately there are some left where the summer days are still gladdened by its presence. It is said that the 


\section{THE BIRD-LIFE OF LONDON}

Nightingale has even been known to breed in Battersea Park, and I can quite believe it, for this charming spot, especially the larger island in the lake, could afford it ample seclusion. The bird seems to be decreasing in some parts of Middlesex, although just beyond our radius in this direction it is still as common possibly as when Milton wrote his immortal sonnet to it in the neighbourhood of Horton and Stoke Poges. One of its most favoured spots in the county is round about Osterley Park; it formerly bred at Golder's Hill. ' In Surrey it is certainly still a common bird, and its voice may be heard at Dulwich, Wimbledon, Richmond, Balham, Tooting, Clapham, Kew, Norwood, Croydon, and so on. In Kent it is extremely common in many places, one of the most favoured in my experience being St. Mary Cray. In Essex, Epping is a famous resort. It would, however, be impossible to tabulate all the localities which the Nightingale frequents. Broadly speaking, it may be heard locally throughout the Metropolitan area, commonest, perhaps, in the west and south. The depredations of cats and bird-catchers are potent factors in the reduction of its numbers and in its extermination from many localities.

The Nightingale reaches the London area about the middle of April, leaving again early in September. Its favourite haunts are small woods and coppices, especially those of a marshycharacter and where there is plenty of undergrowth; and though a somewhat secretive bird, it may often be seen flitting across the more open spaces, where its expanded chestnut tail gleams in the light and affords a ready means of identification. The characteristic song of the male soon proclaims the bird's return, and may be heard with almost as much frequency in the day-time as at night, especially during May. Shortly after arrival many individuals assemble in certain familiar spots, but in a few days a gradual dispersal takes place as all the old 46 


\section{THE NIGHTINGALE}

summer haunts are filled. This assembling may have something to do with mating, and as soon as that is over each pair appears to betake itself to some chosen spot, from which the birds wander little during the summer. The unrivalled and charming song of this species forms one of the sweetest attractions in the bird-world of Greater London. 'The late Richard Bentley told me that Nightingales in his grounds not far from London were somewhat of a nuisance in disturbing the family slumbers! It is at its best in Miay, declines through June, and finally ceases as the autumn moult comes on in July. The Nightingale is by no means the only songster in suburban London that warbles at night: Sedge Warblers, Reed Warblers, and Thrushes do the same; but the voice of these singers can never be confused with it by any observer familiar with its strains. In general habits the Nightingale is very like a Robin; its actions and flight are similar, the flicking of the wings and tail and bobbing motion being very noticeable; whilst its harsh croak of alarm resembles that of a Whitethroat. It feeds on worms and grubs, insects, and larvæ, besides many of the smaller fruits. 'The Nightingale rears but one brood during the summer, and the eggs are laid in May. The nest is made upon the ground, amongst grass, in drifts of dry leaves, or in coarse herbage, and is made of dry grass, moss, and dead leaves (usually of the oak), lined with finer grass and roots and a little horsehair. 'The five or six eggs vary from dark olive-brown to bluish green, the surface colour more or less densely distributed over the shell, in some specimens most pronounced in a circular cap over one end. During the period of incubation the birds become even more secretive, although the male frequently betrays the whereabouts of the nest by his persistent song in its vicinity.

In its appearance the adult Nightingale is one of the most soberly arrayed of birds, the upper parts being 


\section{THE BIRD-LIFE OF LONDON}

russet-brown, shading into chestnut-brown on the tail; the under parts are very palc buff, tinged with grey on the breast and flanks. Bill brown, palest below; tarsi and toes brown; irides rich brown. Length $6 \frac{\mathrm{T}}{2}$ inches. The nestlings are spotted above and below with pale brown, showing close affinity with the Robin, although generically distinct. 


\title{
THE REDS'TAR'T
}

\author{
RUTICILLA PHCENICURUS
}

Local names in surrounding counties: "Firetail" (Essex).

Status in British Avifauna: A somewhat local summer migrant to most parts of England; much rarer in Scotland, and abnormal in Ireland.

Radial Distribution within fifteen miles of $\mathrm{S}_{\mathrm{T}}$. Paul's: The Redstart cannot be described as common or even of frequent occurrence in the Metropolitan area. There are few places where it breeds except in the most remote suburbs, and even there the bird is a local onc. On migration it is sometimes noticed in Battersea, Regent's, and Hyde Parks; but it is more frequently seen in the Wimbledon and Richmond districts, about Kew and Bushey, Osterley, Acton, Wembley, the northern woodlands (Hampstead, \&c.), Epping, Wanstead, the Kentish Crays, Croydon, Banstead, and Epsom. I have seen it in Wimbledon Park during summer, and it is said to have nested at Streatham and Dulwich. There are many localities, of course, in which the Redstart may be met with, but sufficient have been mentioned to indicate its widespread yet local dispersal. A migrant like the Redstart might be noticed almost anywhere when on passage ; it is too conspicuous easily to be overlooked, but the lack of records from many localities seems to confirm the fact of its scarcity close to the city.

The Redstart reaches the south of England early in April, and it is during this month that examples are occasionally seen in inner London, or during August and September, when the return journey is made. Round London its usual summer haunts are large gardens, pleasure-grounds, the borders of woods and coppices, and parks, especially those where old and hollow trees are 


\section{THE BIRD-LIFE OF LONDON}

numerous. Like many other migrants, the Redstart ceems to be much attached to certain spots, returning each year to nest in them. It is a somewhat shy and restless bird, resenting too close a scrutiny, and often hiding away in the tree-tops, from which the short, sweet, but somewhat monotonous song of the male may be heard, especially during May. There is something very Chatlike in the actions of the Redstart. Like those birds it is fond of sitting on a wall or large stone, until approached, when it flits off to another resting-place to await events, all the time it is perched flicking and occasionally spreading out its tail. Its flight is jerky and uneven, and the bright chestnut tail is expanded, rendering the bird easy of identification. Its food largely consists of insects and larvæ, many of the former being secured whilst on the wing; and in late summer many of the smaller fruits and the soft corn are eaten. The Redstart breeds in May, making a slovenly nest of dry grass, moss, and dead leaves, lined with wool, hair, and an abundance of feathers, which it places in a hole of a wall, tree, or rock. The eggs, usually six in number, are pale blue. Both sexes incubate, and after the young are hatched the parents become much more secretive, and when the nest is approached utter a very plaintive note. The young are fed and tended for some time after they leave the nest.

The male Redstart is one of the gayest-coloured of our indigenous birds. The upper parts are mostly slategrey, except the forehead, which is white; the wings are brown, the throat and ear-coverts black, the under parts and tail chestnut. The female is very different, being chiefly sandy brown in colour; the tail, however, is chestnut, but not so brilliant as in the male. Bill, tarsi, and toes black; irides dark brown. Length $5 \frac{x}{4}$ inches. The nestlings are similar in colour to the female, but spotted. 


\title{
THE WHEATEAR
}

\author{
SAYICOLA ENANTHE
}

Locai names in surrounding counties:

Status in British Avifauna: A common and widely distributed summer visitor, becoming most abundant in the wilder and more northern areas.

Radial Distribution within fifteen miles of $\mathrm{S}_{\mathrm{T}}$. PAUL's: It is chiefly as a passing migrant in spring and autumn that the Wheatear visits the Metropolitan area, and at those seasons it is occasionally seen in such spots as Hyde Park, Regent's Park, Primrose Hill, Clapham and Tooting Commons, the various sewage farms, Hampstead Heath, and so forth. Further afield it is not quite so scarce or irregular a visitor to Wimbledon, where it is reported to breed, and I have several records of it in ploughed fields, especially in spring, in the Acton, Perivale, and Willesden districts. I have known pairs and odd birds to remain in a locality for several days, but these individuals are obviously on migration, and soon pass on. Possibly the Wheatear was once common in such spots as Wimbledon and Hampstead, but the wanton trapping that went on in past years has sadly reduced its numbers, to say nothing of the transformation which so many suitable haunts have undergone with the growth of Greater London. It still breeds sparingly and locally within the fifteen-mile limit, possibly more frequently on the highlands of Surrey and in Middlesex than elsewhere; it breeds in Richmond Park.

From the end of March to the beginning of May the Wheatear may be met with on migration over the London area, and again in August and September, when the return passage is in progress. The few that breed in this area take up their abode in the open spots, brickfields, sand-pits, and bare spaces, where they may be easily 


\section{THE BIRD-LIFE OF LONDON}

recognised. The Wheatear is by no means a shy bird, if a somewhat wary one, and it usually first arrests the attention as it sits quietly on some coign of vantage watching your movements or glides along close to the ground to a safer resting-place. As likely as not it utters a series of clicking notes, which sound like pebbles knocked together, accompanying them with a flicking motion of the tail and wings. In the earlier part of the nesting season the male utters a short and rambling song, often when fluttering in the air. 'The food of this species consists of worms, small snails, insects and larvæ, and various small fruits. It is a somewhat early breeder, commencing to build in April, and the eggs are laid during that month and May. A covered situation seems always to be selected, such as under a heap of stones or bricks, a hole in a wall, or a rabbit-burrow. The nest is loosely made of dry grass and roots, lined with hair, wool, and feathers, and the egg-usually five or six-are pale blue. It is a difficult nest to find, and the old birds are wary in the extreme. The Wheatear seldom perches in trees, but often sits on telegraph wires and posts. In autumn Wheatears gather into parties, which eventually become flocks and migrate in company.

The Wheatear cannot readily be confused with any other British species. The male has most of the upper parts bluish grey, merging into white on the lower back; the under parts are pale buff; the eye-stripe and earcoverts are black; above the eye is a white streak; the wings are black; the tail black and white. The female has the body plumage nearly uniform sandy brown, the wings and tail nearly as in the male. Bill, tarsi, and toes black; irides dark brown. Length $6 \frac{\mathrm{r}}{2}$ inches. The young in nestling plumage resemble the female in general colour, but are spotted above and below. 


\section{THE WHINGHAT \\ PRATINCOLA RUBETRA}

Local names in surrounding counties: "Furzechat" (Essex).

Status in British Avifauna: A widely distributed summer visitor, becoming rarer and more local in the south-west of England and in Ireland.

Radial Distribution within fifteen miles of $\mathrm{S}_{\mathrm{T}}$. PAul's: Here again we have a species that with charming persistency returns to old-time haunts that are fast being transformed. I know of several localities-haymeadows close to Wormwood Scrubbs and Park Royalin which the dread notice-board proclaims an "eligible building-site," but to which the Whinchat returns each summer, and will doubtless do so until these selfsame meadows are converted into the hollow pretences of suburban gardens.

The Whinchat, notwithstanding almost yearly changes, still continues to visit most of the outlying portions of the Metropolitan area wherever it can find suitable haunts, such as meadows and rough, furze-grown ground. It is perhaps most local in the Essex portion of the fifteen-mile radius. It breeds at Wimbledon, Streatham, Dulwich, Norwood, and Croydon, and in many intervening places; whilst westwards and north-wards it may be traced over the Richmond, Osterley, Hanwell, Twyford, Sudbury, Wembley, Harrow, Enfield, and Epping areas. In the more outlying districts, where meadows, golf links, and open spaces are commoner, the bird, of course, is met with in increasing numbers. Incidentally I may mention that on April 26, I905, I observed a female Whinchat flitting about the tulips in the ornamental gardens of the Victoria Memorial opposite Buckingham Palace. It frequently perched on the iron 


\section{THE BIRD-LIFE OF LONDON}

railings or on the topmost spray of an evergreen bush, occasionally fluttering into the air in chase of an insect, or hopping about the gravel paths.

The Whinchat is a late migrant, not reaching its summer haunts in the Metropolitan area before the second half of April. Its favourite resorts here are grass-meadows, heaths, and the patches of gorse and broom on commons, railway banks, and similar open places. It leaves them for the south in September. This is another easily recognised species, from its persistent habit of perching on some tall weed in the meadows or on the top of a bush or upon a telegraph wire and monotonously uttering a double note of $u$-tac, which is frequently accompanied by a flick of the wings and tail. When approached it flits off in an uneven manner to another stem or bush, and again repeats its cry. Its food chiefly consists of tiny worms, insects, and larvæ, but in late summer it varies its diet with soft corn. 'The male utters a short and unassuming little song, often whilst in the air, to which both sexes frequently resort in chase of insects. The Whinchat is seen in pairs soon after its arrival, and the eggs are laid in May or early June. The nest is either made amongst the meadow grass, amongst the herbage on some bank, or more frequently amongst the tangled growth under whin or broom bushes. It is a neatly made, cup-like structure, loosely put together, formed outwardly of dry grass and a little moss, and lined with fine roots and horsehair. The five or six eggs are blue, dusted with rusty brown freckles, chiefly on the larger end. The young and their parents remain in family parties for the rest of the summer, migrating apparently in company when the moult is completed. Few nests are more difficult to find, and the old birds are excessively wary throughout the breeding season. Hay-meadows are a favourite resort in late summer, and later on turnip-fields. I have also noted a more arboreal tendency after the young are reared. 


\section{THE WHINCHAT}

The male Whinchat is dark brown on the upper parts, the feathers having paler brown margins, and there is a pale streak over the eye; the ear-coverts are black, and the under parts are rufous; the wings and tail are dark brown, the smaller coverts of the former white, and the latter has the basal half white, except the two centre feathers, which are white at the extreme base only. The female is much paler, and the black and white parts of the plumage are not so pronounced. Bill, tarsi, and toes black; irides brown. Length nearly 5 inches. The nestling resembles the female, but is more spotted above, and the breast is marked with darker brown. 


\section{THE STONECHAT}

PRATINCOLA RUBICOLA

Local names in surrounding counties: "Furzechat," "Blackcap" (Essex).

Status in British Avifauna: A widely distributed resident, somewhat local, and subject to considerable seasonal movement.

Radial Distribution within fifteen miles of St. Paul's: The Stonechat is another species of the more outlying suburbs, the inner portions presenting few if any of the conditions suited to its requirements. It is locally distributed over such furze-clad areas as Wimbledon and Mitcham Commons. I have met with it on Tooting Bec Common, near Croydon, on some of the more extensive heaths, and on open spaces in the vicinity of Park Royal and Epping. It may be met with in the Richmond and Bushey districts, Hounslow, Hanwell, and Epping, whilst many of the Surrey heaths and Kentish wastes well within the Metropolitan area may be given as its habitat. In some places the bird is seldom or never seen in summer; in others its winter absence alone is remarked. I am sure the Stonechat is much overlooked, owing to its secretive ways and the kind of cover it frequents.

From the nature of its favourite haunts the Stonechat must always be a scarce bird within the London district, and there can be little doubt that its habitat will become even more restricted as the suburbs are more densely populated. It is essentially a bird of the wild, uncultivated places, finding its favourite haunts amongst the gorse and the rough, broken ground of commons and heaths; the fields and the hedgerows, the gardens and pleasuregrounds, offer little or no attraction. In its general habits it somewhat closely resembles the Whinchat. It is just as fond of perching on the topmost sprays of its 56 


\section{THE STONECHAT}

cover, is just as alert and watchful, flitting from bush to bush when disturbed, persistently uttering its double note of wee-chic, accompanied by movements of tail and wings. It has the same uneven flight, and a very similar little song. 'The Stonechat, however, often indulges in aerial flights much more extended than any I have ever seen its congener undertake. In May the male occasionally takes long soaring flights on flutterings wings, from time to time hovering stationary for some moments, at a height even of several hundred feet. During these flights it will often chase an insect. Its food is composed of insects, larvæ, small worms, and seeds, the latter probably enabling the bird to winter in our country. It lives in scattered pairs, which apparently do not separate after the nesting season. The Stonechat breeds in April and May, and the nest is usually placed under the shelter of a gorse or other bush, amongst the tall, coarse grass, and is cunningly concealed. It is made outwardly of dry grass, moss, and roots, lined with hair, feathers, and sometimes wool. The five or six eggs are pale bluish green, freckled and spotted with reddish brown. During the nesting season the birds are exceptionally wary, and it requires infinite patience to make them betray the site of their home. The birds remain in family parties well into the autumn in many cases.

The Stonechat is a much showier bird than the Whinchat, and bears no great resemblance to any other British species. 'The adult male has the head, throat, and back black, the rump white, the under parts rich chestnut, paler on the neck and breast; the wings and tail are dark brown, the former marked with white. The female is far less showy, being browner, and the white parts are not so clear. Bill, tarsi, and toes black; irides brown. Length $5 \frac{\text { I }}{4}$ inches. The nestling is spotted and marked with pale brown, and has no trace of the black throat or white patches in the wings. 


\section{THE HEDGE ACCENTOR}

ACCENTOR MODULARIS

LOCAL names in surrounding countics: "Hedge-betty," "Hedge Moke" (Essex).

Status in British Avifauna: A common and widely distributed resident, its numbers increased in autumn by migratory individuals.

Radial Distribution within fifteen miles of St. Paul's: The Hedge Accentor is one of the commonest birds of the Metropolitan area, too often mistaken for a Sparrow, perhaps, but a denizen of London found, say, from the two-mile radius in increasing numbers to the outlying suburbs. That the bird is much overlooked, especially in the central districts, there can be no doubt, but the observant person may detect it in almost every nook where it can possibly find food and shelter. It is a resident in probably all the London parks, and there must be few suburban gardens or shrubberies worthy of the name in which it does not dwell or which it does not visit at one time or another. I know of small gardens in London which are visited regularly by the Hedge Accentor in winter only. A friend of mine told me that a bird of this species has visited his garden regularly for several years, remaining all the winter through, disappearing in spring. This is a common trait of the Robin also, and many other small birds. In some cases these individuals may be migrants from other lands, and then the incident becomes even more interesting.

The Hedge Accentor becomes far more localised in summer, simply because suitable breeding-places are restricted. There are many spots in the London area where this bird can and does pick up a living during the winter, but which for various reasons are quite unsuitable for nesting purposes. Almost any kind of cover 58 


\section{THE HEDGE ACCENTOR}

will content this homely, unobtrusive little bird, and its jerky yet sweet if somewhat short song is almost perennial. 'The male continues in voice right through the year, the moulting season excepted, and even in the severest weather his cheery song may be heard in sheltered spots. The bird rears several broods in the course of the season, preparations often being made for the first, in a mild, open year, as early as February. In the London area its favourite nesting-place appears to be a thick hedge or an evergreen bush, but it will build in a vast variety of spots, and often contents itself with a heap of hedge-clippings or pea-sticks in a quiet corner of the garden. The nest is a substantial one, cup-shaped, and formed externally of moss, dry grass and leaves, and a few slender twigs, warmly lined with hair, wool, and feathers. The five or six eggs are dark turquoise-blue. The habits of this species are somewhat retiring; the bird obtains most of its food on the ground, where it shuffles along picking up minute trifles here and there, slipping off into the bushes if alarmed, and spending most of its time in the concealment of its cover. In severe weather it comes with the Sparrows to our houses, and is one of the most trustful of our feathered visitors. Its food chiefly consists of insects, larvæ, small worms, and a variety of tiny seeds. The call-note of this species is a low and plaintive weet. It is for the most part solitary, but in the pairing season it shows more gregarious tendencies, often congregating early in January in small parties. In the country districts this species is often selected by the Cuckoo to act as fosterparent.

The Hedge Accentor is one of our plainest birds, although there is a chaste beauty in its sombre dress. The adult has the head and nape slate-grey streaked with brown, the remainder of the upper parts reddish brown streaked with dark brown, except the upper tail-coverts, which have an olive tinge; the throat and breast are 


\section{THE BIRD-LIFE OF LONDON}

grey, merging into pale greyish buff on the rest of the under parts, darkest on the flanks, which are streaked with brown. Bill dark brown, paler below; tarsi and toes light brown; irides brown. Length $5 \frac{\text { T }}{2}$ inches. The nestling resembles the adult, but is more thickly spotted. 


\title{
THE GRASSHOPPER WARBLER
}

\author{
LOCUSTELLA NAVIA
}

Local names in surrounding counties:

Status in British Avifauna: A local and capricious summer visitor, generally distributed over England and Wales, the south of Scotland, and Ireland.

Radial Distribution within fifteen miles of $\mathrm{S}_{\mathrm{T}}$. PAUL's: The Grasshopper Warbler is found in various parts of the Metropolitan area, but from its excessively skulking habits it is very often overlooked. It is local certainly, but is a regular summer visitor to the gorsecovered commons and heaths at no very great distance from the City. Perhaps its nearest haunts are at Wimbledon; and Coombe Wood is said to be another. Then it is recorded as a summer visitor to suitable spots in the Hendon, Kingsbury, Harrow, and Hampstead districts; Wembley, Osterley, and Croydon neighbourhoods are others. It frequents suitable areas in the Kentish Crays, and across the river is a regular visitor to Epping, and is said to haunt Dagenham Lake, near Ilford. Doubtless there are many tangled bits of cover where the Grasshopper Warbler skulks through the summer undetected. There are many such rural spots within London's limits where the bird's song might be mistaken for the sibilant sound of the grasshopper, as even in districts where this Warbler is absolutely common it only shows itself exceptionally and for fleeting moments.

There are few other British birds so difficuit of observation as the Grasshopper Warbler, and the ordinary birdlover may well be excused if he fails to meet with it in spots it is absolutely known to frequent. Its favourite haunts are dense thickets and mazes of brushwood in small woods or on commons or by the roadside, as well as tangled hedge-bottoms, ditches, and the luxuriant 


\section{THE BIRD-LIFE OF LONDON}

masses of vegetation by the waterside. Here it skulks the summer through, its actions more like those of a mouse than wbird, and only at irregular and quiet intervals appearing a ithin view, when it seems to think it is not observed. The slightest alarm sends it quickly to cover, and then only the vibration of a twig here and there or the trembling of the tall grass-stems indicates its creeping, gliding passage through the dense cover. Possibly this Warbler may arrive in the London area about the middle of April, but its appearance is seldom noted until its presence is disclosed by its curious song, which is usually first heard near the end of that month, or in some seasons not before the beginning of May. Its departure also is somewhat a matter of conjecture, but close and persistent observation fixes the date as the end of August or early in September. It must be remembered that the bird is then practically silent, so no clue to its movements or presence is afforded by its voice. The chirp of the grasshopper or the squeak of the field-mouse prolonged for as long as several minutes at a time will give a good imitation of the voice of the Grasshopper Warbler. It announces its presence with this persistent, monotonous trill, like no other bird-music in England, which is uttered not only at all hours of the day, but very often during the warm, still summer nights. This curious song appears to be confined to the male, but both sexes utter the usual tectec call-note so common with the Warblers in general. At fitful intervals a glimpse of the bird may be obtained, either when driven out of one cover to another or when for a fleeting moment it runs up some taller stem or branch than the rest, and then drops down again. Its flight seems feeble enough, but that its powers of wing are considerable is proved by the long migrations it performs twice every year. The food of this Warbler consists of insects, larvæ, and various small fruits. It is a somewhat late breeder, the eggs being laid during May 62 


\section{THE GRASSHOPPER WARBLER}

or June. Its nest is cunningly concealed either on the ground or just above it in the tangled lower vegetation of its haunt, long grass being a favourite situation. It is deep and cup-shaped, compact, and made outwardly of dry grass, dead leaves, and moss, and lined with fine round grass-stalks. Thefive or six eggs are white suffused with the palest pink, spotted and profusely dusted with reddish brown and grey, with an occasional streak of dark brown. The female sits closely, and glides from the nest in a very silent manner, seldom betraying its whereabouts. One brood only is reared in the season.

The adult Grasshopper Warbler is olive-brown above, spotted with darker brown of the same shade, buffish brown below, merging into nearly white on the chin and belly, and the under tail-coverts have brown shaftmarks. Bill dark brown, paler below ; tarsi and toes light brown; irides brown. Length $5^{\frac{1}{2}}$ inches. 'The nestlings are yellower in tint, and have many dark markings on the throat and flanks. 


\title{
THE REED WARBLER
}

\author{
ACROCEPHALUS ARUNDINACEUS
}

Local names in surrounding counties: "Reedchat" (Essex).

Status in British Avifauna: Common yet local summer visitor to England, most abundant in the south, and rarest in the north and west.

Radial Distribution within fifteen miles of $\mathrm{S}$. Paul's: Although the Reed Warbler is seen occasionally even so close to the city as Battersea Park, I know of no summer haunt of this species nearer than Richmond. There are certain breeding-places in the valleys of the Thames and the Colne within the Metropolitan area, but the Reed Warbler does not become in any way common until we get a score or so of miles from the city. The bird is found in summer at Virginia Water, Betchworth, Cobham, and other places, but everywhere it is a local one, and one also that may be very easily overlooked. It is difficult to explain the bird's absence from many spots that appear to be ideal summer haunts, and in the north-east and south-east especially the species is uncommon. Where found this Warbler is usually abundant, numbers of pairs living in the same bed of reeds or belt of osiers.

That the Reed Warbler is somewhat capricious in the choice of a haunt or seeks localities where some special food is abundant seems proved by the fact that it frequents many unlikely districts, and continues to visit them after they have undergone considerable change. I know of haunts of this Warbler that have been considerably curtailed by drainage and building operations still continuing to be frequented, and even after most of their privacy has been destroyed. On the other hand, I can call to mind many more, ideal in every way so far as can 64 


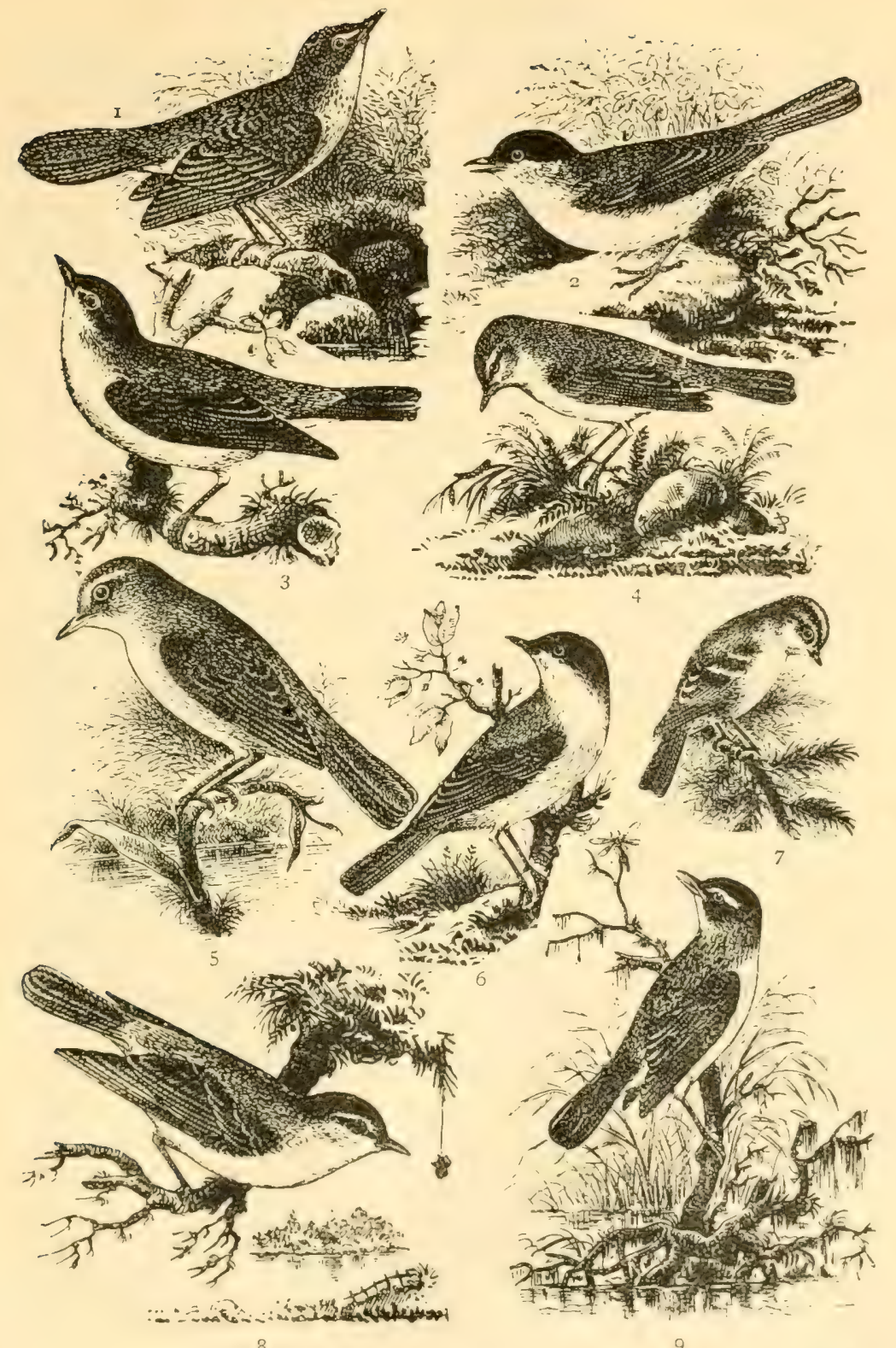

8

I. Grasshopper Warbler. 2. Blackcap Warbler. 3. Garden Warbler. 4. Chiffchaff. 5. Reed Warbler. 6. Lesser Whitethroat. 7. Goldcrest. 8. Wood Wren. 9. Sedge Warbler. 



\section{THE REED WARBLER}

be judged, in which a Reed Warbler never by any chance is seen. The vivid green spears of the reeds are showing well above the brown, rotten growth of the preceding year and vegetation by the waterside is becoming full and generous before the Reed Warbler appears at the end of April or the beginning of May. Already hosts of summer migrants are filling the woods and fields with music before the first strains of the Reed-bird's chattering melody issue from the greenery of the waterside. Once here, however, he is a persistent songster indeed, and his voice day and night is a pleasing feature of his haunt. The song in parts is harsh and grating enough, but there are interludes of singular power and sweetness; he mars his best endeavour by introducing jarring fragments that seem to interpret defiance and anger rather than joy. It is a song of wild contrasts, varied in the extreme, and occasionally sounds as if the performer were threading the notes of half a dozen other birds into his own refrain. The Reed-birds are shy enough, or perhaps we ought rather to say that they prefer the cool, green seclusion of the rustling reeds to the sweltering sunlight of the outer growth. Here more likely than not a trembling stem or a harsh"churr are the only signs of their presence; but at fitful intervals a glimpse is obtained of a bird crossing the more open waterways amongst the reeds and osiers, or clinging to a bending stem, to drop down again at once into cover. Now and then you may be fortunate enough to see a bird flitting to and fro or running mouse-like up the round, polished stalks of the reeds, singing all the time. The song is most prevalent in calm, warm weather; rough wind and a cool atmosphere are not conducive to music. They are quarrelsome little creatures, resent intrusion, and each pair appear to have vested rights in some particular spot, from which they seck to drive off all trespassers. Pairing begins soon after their arrival, and the eggs are laid in May or early June. 


\section{THE BIRD-LIFE OF LONDON}

The deep, cup-shaped nest may either be built hammockwise amongst the reed stems or suspended from one or two thin twigs, at a height of a few inches or several feet from the water, over which it is usually made. The materials are woven round several reed stems or twigs, and consist of dead grass and various aquatic herbs, leaves of last year's reeds, bits of moss, and roots, lined with finer grass and roots, a little hair, and sometimes particles of vegetable down, or even a few feathers. The four or five eggs are pale greenish blue, spotted and blotched with greenish brown, pale brown, and grey, with occasionally a few dark hair-like lines or freckles. The old birds become very restless and scolding if their nest be menaced. But one brood is reared, often after several attempts, and the return migration takes place in September. The food of this Warbler is almost if not entirely composed of insects and larvæ, such as haunt the waterside, but its frequent visits to gardens may be for the smaller fruits. Although it flies in an apparently feeble and hesitating manner its powers of wing must of course be very considerable to enable it successfully to cross the seas twice each year.

The adult Reed Warbler is olive-brown above, with a perceptible tinge of rufous on the rump, the pale eyestripe very indistinct, and pale buff below, becoming nearly white on the throat and centre of the belly. Bill dark brown above, pale brown below; tarsi and toes greyish brown; irides brown. Length $5 \frac{\text { t }}{2}$ inches. 


\section{THE SEDGE WARBLER}

ACROCEPHALUS PHRAGMITIS

Local names in surrounding counties: "Night Warbler" (Essex).

Status in British Avifauna: A common summer visitor, widely distributed, and found in all suitable localities.

Radial Distribution within fifteen miles of St. PAUL's: 'The Sedge Warbler is certainly more generally dispersed and commoner than the Reed Warbler in the Metropolitan area. To begin with, it is far less fastidious in the selection of a haunt, and often makes its summer retreat on the banks of small ponds and ditches which the rarer species would shun. I have records of its breeding at Dulwich, Wimbledon, Kew, and Richmond; it is found in many localities within our radius in North Surrey and Kent; whilst in Middlesex it may be met with in most suitable spots about the Brent, the canal banks at Twyford, Park Royal, Wembley, Harrow, Kingsbury, the northern suburbs, and east to Epping, Wanstead, Ilford, and Dagenham. The Sedge Warbler is much attached to its haunts, and will continue to visit them after much of their once great privacy has been disturbed by the growing exodus of London's population. On several occasions I have remarked how the noisy rowing of some Cockney band on river or canal has called this Warbler into scolding songs of resentment. It is a skulking bird, and very often overlooked in localities where its presence might never be suspected.

Such Sedge Warblers as spend the summer within the area of Greater London reach their usual haunts towards the end of $\Lambda$ pril, and, like the preceding species, leave them again in September. Although not quite so exclusively aquatic, this bird somewhat closely resembles 


\section{THE BIRD-LIFE OF LONDON}

the Reed Warbler in its habits and economy. It is perhaps not quite so retiring, but resents scrutiny, and hides away amongst the cover with little provocation. It sings with equal persistency, both by day and by night, its voice being a mixture of pleasant warbling and harsh, discordant chatter. Most birds cease their song if disturbed; the Sedge Warbler may usually be induced to break into music by throwing a stone into the cover. Many pairs frequent one locality, not from any social tendency, perhaps, but owing to the suitability of the situation. Shortly after arrival the birds are somewhat restless, and may often be seen in the trees and hedges; pairing may have something to do with this, for as the breeding season comes on more secretive habits are developed. During its stay with us the Sedge Warbler seldom takes any extended flights, confining itself chiefly to the cover, where it is for ever in motion, slipping about amongst the vegetation, appearing fitfully here and there, and from time to time uttering a scolding churr or a string of chattering cries. It feeds chiefly upon insects and larva and small worms, to which are added the smaller fruits. The nest is made in May or early June; and in the matter of its family arrangements the Sedge Warbler is by no means confined to the waterside, neither does it suspend its cradle from reeds or twigs. It is usually placed amongst the long matted grass and weeds growing on a bank, or at the foot of an osier or other bush, frequently in the branches of a willow, or in a dense hedge or thicket of brambles, briars, nettles, and so forth. It is a small, cup-shaped structure, loosely made of dry grass, moss, and withered leaves of aquatic plants, lined with horsehair, a little down, or even a few feathers. One I recently saw from the banks of the Brent near Stonebridge had a fair quantity of the latter. The five or six eggs are greyish white, more or less densely freckled with yellowish brown, and sparingly streaked (sometimes not at all) 68 


\section{THE SEDGE WARBLER}

with dark brown lines and scratches. The nest is only discovered with difficulty, and, as is usual with so many Warblers, the sitting bird slips off in a very stealthy manner when disturbed.

The adult Sedge Warbler is russet-brown above, each feather with a dark brown centre, very pronounced on the head and wings, and absent from the rump, which is of a more rufous tinge. The eye-stripe is pale buff; the under parts are pale buff, darkest on the breast and flanks. Bill dark brown above, paler below; tarsi and toes pale brown; irides brown. Length $4 \frac{3}{4}$ inches. 


\section{THE WHITETHROAT}

\section{STLVIA CINEREA}

LOCAL names in surrounding counties: "Hayjack," "Haychat" (Essex).

Status in British Avifauna: A common and widely distributed summer visitor.

Radial Distribution within fifteen miles of St. PAUL's: Although the Whitethroat cannot be regarded as a visitor to the inner portions of the Metropolitan area, there are many places in the suburbs where it is fairly common during the summer. I have never met with this species in any of the strictly urban parks and pleasure-grounds, though there are some in which it might be reasonably expected, as, for instance, in the Botanical Gardens; on the other hand, I may mention Dulwich and Wimbledon as districts it regularly frequents. Regarding the more outlying areas, however, there are many spots still sufficiently rural to afford it a suitable summer residence. It may be noticed in many parts of Middlesex-Park Royal, Wembley, Harrow, Kingsbury, Hendon, and so forth; whilst in Essex it regularly visits the Epping district, Wanstead, and Dagenham. In Kent it has many haunts about the Crays and elsewhere; whilst Surrey, of course, affords it others in many scattered localities well within the fifteen-mile radius-Kew, Richmond, and so on. I have heard of this species as a visitor to large gardens in the autumn much nearer the city, where a plentiful crop of fruit has, of course, been the chief attraction.

If there are Whitethroats in a locality the fact can scarcely be overlooked by any one familiar with the species. The bird is particularly partial to hedges, and has a habit of mounting to the top of them to sing, flitting along before the observer, hovering in the air, or con70 


\section{THE WHITETHROAT}

cealing itself amongst the dense foliage, where the unmistakable call-note of tay-tay-tay and the trembling of the twigs proclaims its presence. The Whitethroat reaches the London district towards the end of April, in most seasons late enough to evade the last snap of winter, and when insect life is stirring in abundance. This is not always the case, however, for in the spring of I 908 the Whitethroat and many other migrants had an experience which fortunately is rare. The last ten days of April were marked by wintry conditions, and several falls of snow occurred. It was a novel sight on April 24 to watch the Whitethroat near Sudbury flitting about snow-draped hedgerows and across the white fields, silent and ill at ease, in company with Willow Warblers, fellow wanderers in distress. Probably the birds had never seen snow before, and there can be little doubt that the Whitethroats at any rate perished for lack of food. The return migration of the Whitethroat takes place in September. The song of this species is a blithe, sweet, garrulous little lay, rich with a wild beauty all its own. The bird is a most industrious singer, and as often as not warbles as he flies or whilst threading his way with wonderful speed through the matted hedges. He continues in voice until the end of July. The food of this species is largely composed of insects and larvæ, but soft corn and garden fruits are eagerly sought. Its nesting season is in May and June. The simple little nest may be found in a great variety of situations, in gardens and hedges, amongst the tangled vegetation by the roadside or in any convenient thicket of briar, brambles, or nettles, sometimes close to the ground, at others several feet above it. It is a flimsy little structure, a deep and rounded cup, chiefly composed of dead grass, stalks, and roots, lined with horsehair. The five or six eggs range from greyish to buffish white in ground colour, mottled, clouded, and freckled with light brown and olive- 


\section{THE BIRD-LIFE OF LONDON}

brown and grey. But one brood is reared. In autumn the Whitethroat commonly resorts to cornfields and gardens, and on migration frequently visits unusual localities.

The adult male Whitethroat has the head grey, the rest of the upper parts pale brown, margined on the wings with chestnut; the outer tail-feathers are bordered with white; the under surface is white, with a rosy tinge on the breast and a buff one on the flanks. The female has a brown head, and lacks the rosy tinge on the breast. Bill dark brown, paler below ; tarsi and toes pale brown; irides pale brown. Length $5^{\frac{\pi}{2}}$ inches. The young closely resemble the female in colour. 


\section{THE LESSER WHITETHROAT}

\section{STLVIA CURRUCA}

LOCAL names in surrounding counties:

Status in British Avifauna: A local summer visitor; rarer in the extreme west, and in Scotland; of only abnormal occurrence in Ireland.

Radial Distribution within fifteen miles of $\mathrm{S}_{\mathrm{T}}$. PAUl's: In the Metropolitan area, as almost everywhere else, the Lesser Whitethroat is less common and more local than the preceding species. It is a bird, however, that is often overlooked, and mayjustly be classed as a regular summer visitor to many places within the limits of London's suburbs. During the seasons of migration, in autumn especially, this little species frequently visits small gardens within the six-mile radius, and I have records from Kensington Gardens. In the autumn of I904 I noticed a Lesser Whitethroat among some rows of peas (the only cover the wretched apology for a garden contained) for several days in succession, whilst I have frequently observed it in allotment gardens not very far from the City. To the more central suburbs it is certainly a regular summer visitor, breeding at Dulwich, whilst it is by no means rare in the Willesden, Wembley, and Hendon districts. I have also summer records of it from the Ealing, Acton, Kew, and Gunnersbury areas; whilst, of course, further afield it becomes commoner, round Wimbledon, Richmond, Osterley, Southall, Kingston, Merton, Ewell, Croydon, the Crays, Dartford, Ilford, Wanstead, Epping, Enfield, Barnet, and Harrow.

Within the limits I have given and in the vicinity of all the places specified the Lesser Whitethroat may be met with during summer. It arrives near the end of April, and migrates south in September. With the important exception that the Lesser Whitethroat shows a greater 


\section{THE BIRD-LIFE OF LONDON}

preference for trees, its habits otherwise closely resemble those of the preceding species. This propensity for the higher vegetation is the reason the bird is so frequently overlooked and thought to be much rarer and more local than it really is. It has the same restless disposition, the same secretive ways, as its larger congener. Frequently it may be seen to flutter out from some tree into the air in chase of an insect. Its song is nothing nearly so sweet as that of the common Whitethroat, and consists of a few twittering notes, often uttered during flight; its call-note is a grating tec-tec. The food of this species is largely composed of insects and larvæ, especially aphides; and the smaller garden fruits, such as currants and raspberries, are greedily sought. The nesting season is in May and June. The nest is often built quite close to the ground, amongst brambles or gorse and similar matted vegetation, but at other times is placed in a tall thick hedge. It is not so deep as that of the common Whitethroat, but made on the same flimsy design, outwardly of grass stalks and bents and inwardly of horsehair. The four or five eggs range from white to buff in ground colour, blotched and freckled with greenish brown and grey, and occasionally scratched with dark brown. The eggs are a little smaller than those of the preceding, and the spots are more clearly defined. But one brood is reared.

The adult Lesser Whitethroat is pale slate-grey above, with a brownish tinge on the back and ear-coverts; the wings and tail are brown, the inner secondaries with pale brown margins, and the outer feathers of the latter tipped with white; the under parts are pale brown, shading into white on the throat, centre of the abdomen, and under tailcoverts. The female closely resembles the male in colour. Bill dark slate-grey, paler at the base of the lower mandible; tarsi and toes slate-grey; irides pale brown. Length $5 \frac{1}{4}$ inches. The nestling closely resembles the adult in general coloration.

\section{4}




\title{
THE GARDEN WARBLER
}

\author{
STLVIA HORTENSIS
}

Local names in surrounding counties:

Status in British Avifauna: A somewhat local and capricious summer visitor, but very generally distributed rarest in the south-west of England, in Wales, parts of Scotland, and in Ireland.

Radial Distribution within fifteen miles of $\mathrm{S}_{\mathrm{T}}$. Paul's: The Garden Warbler is a fairly common summer visitor to suitable places in the Metropolitan area, but its skulking habits cause it very frequently to be overlooked. It is very possible that this Warbler breeds locally within the five-mile radius, in which it is a tolerably frequent visitor to many gardens and some of the parks during spring and autumn migration. It is said to breed at Dulwich and Ranelagh. Beyond this boundary it becomes, of course, a more regular visitor, and it may be traced through most suitable neighbourhoods from Wimbledon and Richmond, Twickenham, Kew, Osterley, Hanwell, Wembley, Willesden, Barnet, Waltham, Beckenham, Norwood, Mitcham, Merton, and Kingston. In the remoter suburbs I have evidence of its regular occurrence in the districts of Croydon, the Kentish Crays, Banstead, Cheam, Epsom, Bushey, Teddington, Hounslow, Southall, Harrow, Waltham, Epping, Wanstead, and Rainham. These localities are only indicative of the general distribution of the species; it occurs in a great many others, no doubt, but sufficient has been said to trace its distribution within the fifteen-mile limit.

Considering the number of large gardens, nurseries, orchards, and shrubberies in the suburbs of London, the wonder is that the Garden Warbler is so local and comparatively scarce. It is more than possible that the bird, owing to its secretive, unobtrusive habits, escapes notice 


\section{THE BIRD-LIFE OF LONDON}

altogether. A better look-out should be kept for it. This Warbler is one of the latest summer migrants to reach the London area, seldom being seen or heard before the first week in May. Like all its congeners, it is shy and retiring, resembling them in its habits generally. It is fond of skulking in the dense thickets and other cover of its haunts, threading its way through the maze of twigs with great celerity, a shaking branch here and there and an occasional harsh tec-tec being the only indication of its whereabouts. Like all its kind, it is restless in its search for food, appearing at intervals in the open, crossing from one bush or hedge to another with apparent reluctance, and always preferring to wander from one part of its haunt to another hidden by the shelter of the leaves. If its song were only louder it would compare not unfavourably with that of the Blackcap; it is not quite so rich or so flute-like, but its beauty is certainly marred by its singular softness. The cock is much too modest in his utterance, and spoils much of its effect by warbling so far in the cover. At rare intervals he will mount to some higher spray, as if moved by a sudden impulse, and warble for a moment or so in full view; and sometimes, Whitethroat-like, he sings as he flies. The food of this Warbler consists of insects, larvæ, and small fruits, especially currants and raspberries. Insects are sometimes caught in the air. The nesting season is in May and June, and the nest is well concealed amongst nettles or other coarse plants, in fruit bushes, rows of peas, in thickets, briars, and brambles. It is a simple, net-like little structure, cup-shaped, and made of fine grass stalks, roots, a little moss, and lined with horsehair. The five or six eggs are white, sometimes with a greenish or buffish tinge, blotched, mottled, and freckled with olive-brown, pale and buffish brown, and grey. But one brood is reared in the year.

The adult Garden Warbler is olive-brown above, darkest on the wings and tail; the under parts are pale 76 


\section{THE GARDEN WARBLER}

grey, nearly white on the abdomen, and darkest on the breast and flanks; the axillaries and under surface of the wings are buff. Bill dark brown, paler on the base of the lower mandible; tarsi and toes slate-grey; irides bright brown. Length 6 inches. The young birds closely resemble the adult in colour. 


\section{THE BLACKCAP}

STLVIA ATRICAPILLA

Local names in surrounding counties:

Status in British Avifauna: A common and widely distributed summer visitor, but becoming local in Scotland and Ireland. Occasionally met with during winter.

Radial Distribution within fifteen miles of $\mathrm{S}_{\text {t. }}$ PAUL's: Whether the more conspicuous appearance of the Blackcap has anything to do with the widely prevailing opinion that this bird is commoner than the Garden Warbler in the Metropolitan area I am not prepared to say. Whatever may be the reason, it is reported as more or less numerous in every suitable part of London's extensive suburbs. Its breeding-places, of course, in the most central localities are few, Dulwich, perhaps, being the nearest point to St. Paul's, or even possibly Battersea and Regent's Parks. On migration the Blackcap may appear in any of the urban parks; I have records from Hyde Park; but its visit is transient, and may be generally overlooked. In the more rural suburbs, such as Croydon, Norwood, Streatham, Wimbledon, Richmond, Kew, Ealing, Wembley, Willesden, Barnet, Enfield, Waltham, Epping, Ilford, and Bromley, the bird is fairly numerous, but decreasing in some places where the builder is becoming too aggressive. Beyond these limits, again, in the still more rural and quieter localities the species becomes generally dispersed, and in some parts may be classed as quite a common bird. Notwithstanding the Wild Birds Protection Acts, many Blackcaps are still caught in the environs of London. More's the pity!

The breaking up for building purposes of so many beautiful rural spots in the suburbs of London is causing the Blackcap and many other charming birds to decrease sadly in numbers. The destruction of Wembley Park 78 


\section{THE BLACKCAP}

is one of the most pitiable of recent instances. In a belt of glorious shrubbery there the Blackcap could be heard in numbers all the summer through warbling deliciously, the Rooks cawing noisily in the trees overhead. There the Goldcrest bred, Titmice and Creepers had their haunt, and the Thrush and Blackbird piped the livelong day. All is now laid bare and desolate; in the meadows adjoining, some of the most magnificent timber round London has been felled; everything of beauty is given over to that arch-spoiler the speculative builder! The Blackcap reaches its London haunts about the middle of April, and its arrival is soon loudly proclaimed by its beautiful song; it migrates south again in September. The favourite haunts of this Warbler are shrubberies, coppices in which plenty of brushwood clothes the ground, dense thickets and hedges, orchards and large gardens. It by no means confines itself to the thick growth, and often visits the trees, or sits and sings on some exposed spray; but it is fond of cover, and like all its kindred threads its way through the branches with celerity, from time to time uttering a harsh tec-tec as if of warning or defiance. The song of this Warbler is flute-like and beautiful in the extremenot even the Nightingale rivals it for sweetness or variety. If undisturbed the bird will continue in song for minutes at a time, and it is then one can realise the wonderful compass and power of his matchless melody. He continues in voice until the young are reared, ceasing with the approach of the autumn moult. The food of this Warbler consists largely of insects and larvæ, but fruit is eagerly sought, and even the berries of the ivy and the yew. It begins nesting early in May, building its home amongst the dense thickets and hedgerows. The nest is a beautifully neat and rounded cup, slightly put together, made externally of grass stalks, flakes of moss, roots, and lined with horschair. As is the case with most 


\section{THE BIRD-LIFE OF LONDON}

Warblers, bits of cobweb and cocoons are used to bind the materials together. The five or six eggs are white, sometimes suffused with blue or red, in ground colour, clouded and blotched with various shades of brown and grey, and occasionally scratched with very dark brown. Both sexes incubate, and the sitting bird frequently shows great fearlessness at the nest.

The adult male Blackcap has the forehead and crown jet-black, the remainder of the upper parts grey, suffused with olive on the quills and tail; the under parts are pale bluish grey, becoming nearly white on the abdomen. The female resembles the male in general coloration, but her forehead and crown are chestnut-brown. Bill dark brown; tarsi and toes lead-colour; irides brown. Length $5 \frac{3}{4}$ inches. The young of both sexes resemble the female in colour. 


\title{
THE DARTFORD WARBLER
}

\author{
STLVIA PROVINCIALIS
}

Local names in surrounding counties:

Status in British Avifauna: An extremely local resident in the southern, eastern, and central counties of England; extinct in certain localities where it was once common.

Radial Distribution within fifteen miles of $\mathrm{S}_{\mathrm{T}}$. Paul's : The Dartford Warbler is a species in which I have always taken exceptional interest. Nearly thirty years ago I obtained its nest in the most northerly recorded locality in England (in the Rivelin Valley, on the outskirts of Sheffield). The fact has been ignored by some recent writers, and doubted by others (including $\mathrm{Mr}$. Saunders, for reasons best known to himself), but the nest and eggs were in my collection for years, and at the time I took them I stood for several minutes examining the mother bird as she brooded on the nest within reach of my hand. I thought little of the occurrence at the time, and it was-not recorded till several years afterwards in the History of British Birds. A special interest also attaches to this species, because it was actually first discovered and made known to science from specimens obtained on Bexley Heath, near Dartford, some fifteen miles from St. Paul's. It is certainly a very lecal bird in the Metropolitan area, and may nest only in suitable spots in Surrey and Kent at the extreme limits of the radius. It has been recorded from Wimbledon, as having bred at Hampstead, as frequenting Stanmore Common and Harrow Weald Common, and as having been obtained at Old Oak Common and Wormwood Scrubbs, both in the Willesden area. There are many gorse coverts within the Metropolitan radius where this skulking bird might find a suitable haunt, and it is 


\section{THE BIRD-LIFE OF LONDON}

just possible that it has been overlooked in some of them.

Although there is much of intense interest in the habits of the Dartford Warbler it will not be necessary to dwell upon them at any great length in the present volume, because the bird is so utterly local, and is not likely to come before the notice of many observers in Greater London. The most remarkable fact about this species is that it is a resident; all the other Warblers are migrants, yet this tiny creature manages to exist in England through the severest winters. It may be that it can always find food of some kind amongst the dense gorse coverts it frequents, such spots offering a sanctuary to those lower forms of insect life upon which this Warbler largely subsists. A good deal still requires to be investigated concerning the food of this particular species. There are few shyer or more restless and retiring birds than the Dartford Warbler. It keeps close to the gorse, only at fitful intervals appearing on the higher sprays, and then but for a moment or so. Sometimes it indulges in a little soaring flight above the cover, but soon drops down again into it like a stone. Its call note of pit-it-chou is very characteristic, but it also utters a sound like the familiar tay-tay of the Whitethroat. During the breeding season-between May and June-the cock bird may be heard to warble a short yet musical little song. The nest for the first brood is made in April, for the second in June. It is usually placed close to the ground, amongst dead gorse and grass, a loosely built structure, made of round dry grass stems, bits of dry gorse, and moss, and lined with scraps of wool, finer grass stalks, and hair. The four or five eggs so closely resemble those of the Whitethroat that they can only be distinguished with the greatest difficulty. As a rule the markings are perceptibly more clearly defined, and darker. 


\section{THE DARTFORD WARBLER}

The adult male Dartford Warbler is sooty brown above, shading into dark slate-grey on the head; the wings are marked with pale brown; the tail is dark slate-grey, like the head, but the outer feathers are marked with white. The under parts are chestnut-brown, flecked with white on the throat, and merging into white on the abdomen; the under tail-coverts are grey, tipped with white. The female is duller than the male, and the under parts are very much paler and more uniform in tint. Bill dark brown, nearly black, paler at the base of the lower mandible; tarsi and toes pale brown; irides orangeyellow. Length 5 inches. The nestlings are browner above and buff below. 


\section{THE WOOD WARBLER}

PHYLLOSCOPUS SIBILATRIX

Local names in surrounding counties:

Status in British Avifauna: A local and somewhat capricious summer visitor to all suitable districts in England and Wales; much rarer in Scotland, and only found in a few places in Ireland.

Radial Distribution within fifteen miles of $\mathrm{S}$ t. Paul's: Of the Willow Warblers the present species is decidedly the least common within the Metropolitan area. It is everywhere local, and chiefly confined to the more outlying suburbs, where woods are plentiful. I have records of the Wood Warbler from Richmond and Wimbledon; it is also said to frequent the vicinity of Dulwich. In Middlesex, Bushey, Osterley, Wembley, Harrow, Pinner, Ruislip, and Enfield may be mentioned as haunts. It has also been recorded from the Hampstead district, and has been observed in Highgate Woods. It is a very local visitor to the Epping area, and may possibly be a regular summer migrant to the vicinity of Wanstead. Of Kent I possess little authentic information, but I have repeatedly heard the sibilant song of the Wood Warbler in the area of the Crays and near High Elms, as well as a little further west, between Shirley and Croydon. During migration this pretty Warbler occasionally pays fleeting visits to gardens and private grounds much nearer to the city, but as it is silent in autumn it is often overlooked in the tops of tall trees, or mistaken for its smaller congeners.

There are fortunately many noble woodlands well within the fifteen-mile radius which offer a congenial summer retreat to the Wood Warbler-the largest and brightest coloured of the three little species known collectively as Willow Warblers. The favourite haunt of 84 


\section{THE WOOD WARBLER}

this species is amongst trees, not necessarily woods, for the bird may be observed in isolated trees in the fields, in small coppices, in orchards, parks, and pleasure-grounds. The Chiffchaff also loves the trees to a great extent; the Willow Warbler shows more preference for lower vegetation. It is this proneness for arboreal celsitude that enables the Wood Warbler so often to elude discovery, although its very characteristic song and call-note should furnish a ready means of identification. The Wood Warbler is the latest of the trio to reach us in spring, not arriving before the end of April, and it departs some time in September. Its sojourn here is largely spent amongst the foliage, which it persistently searches for insects, slipping about amongst the leaves, fluttering below them, and hopping from twig to twig, occasionally uttering a note like dee-ur, oft repeated; and from time to time the male gives forth a string of rapid notes, followed by a harsh trill, which constitutes his song. In addition to insects and larvæ, there can be little doubt that the Wood Warbler also eats the smaller fruits. The nest of this Warbler is made in May or early June, and is always placed upon the ground amongst the herbage. It is semi-domed, made externally of dry grass, bits of moss, and a few dead leaves, lined with horsehair, never with feathers, as is the case with its two congeners. The halfdozen eggs are white, profusely spotted and freckled with rich brown and grey. It rears but one brood in the season. The nest is difficult to discover, the female being very cautious and secretive, but the male frequently betrays its proximity by his persistent song in the trees overhead.

The adult Wood Warbler has the general colour of the upper parts yellowish green, brightest on the rump and upper tail-coverts; the very distinct eye-stripe is sulphuryellow; the wings and tail are brown, margined with yellowish green. The under parts are white, suffused 


\section{THE BIRD-LIFE OF LONDON}

with yellow, more especially on the throat and neck. Bill dark brown, paler at the base of the lower mandible; tarsi and toes brown; irides brown. Length $4 \frac{3}{4}$ inches. The nestlings are similar in colour to the adults, but a trifle duller-greener, in fact. 


\section{THE WILLOW WARBLER}

\section{PHTLLOSCOPUS TROCHILUS}

Local names in surrounding districts:

Status in British Avifauna: A common and widely distributed summer visitor, found almost everywhere.

Radial Distribution within fifteen miles of St. Paul's: The Willow Warbler is one of the commonest of the smaller summer migrants to be found throughout the Metropolitan area in most suitable places in the wooded and rural suburbs. I have records from many of the urban parks, having seen this species in St. James's Park, Battersea Park, Hyde Park, Regent's Park, Victoria Park, on Clapham Common, and in some of the larger cemeteries, although I cannot say that it nests in any of them. Beyond these limits, however, we reach districts where the Willow Warbler habitually spends the whole summer. It would be impossible to mention all of them here, but I may instance such localities as Dulwich, Putney, Streatham, Tooting, Wimbledon, Richmond, Kew, Osterley, Acton, Ealing, Hanwell, Willesden, Harlesden, Wembley, Harrow, Highgate, Hampstead, Hendon, Enficld, Waltham, Epping, Wanstead, Ilford, the Crays, Croydon, Norwood, Sydenham, Mitcham, Ewell, Kingston, and Merton. As our radius widens into the country the Willow Warbler becomes even yet more abundant; whilst in spring and autumn it is by no means an uncommon visitor to gardens and private grounds within a few miles of the City.

This pretty bird, one of the smallest of our summer migrants, reaches the London suburbs early in April, and quits them again at the end of September or early in October. Nlert and restless, it may be watched hopping from twig to twig, ever and anon bursting into a delightful little song-a series of sweet and plaintive notes in a 


\section{THE BIRD-LIFE OF LONDON}

descending scale, finishing so softly as to be scarcely audible. It makes itself as equally at home in a large garden or orchard as amongst the hedgerows and coppices and shrubberies of more rural spots. It is a most persistent singer too, and throughout April and May makes its haunts melodious as one bird answers another from the leafy bowers. Its call-note is equally pleasing-a plaintive weet, long-drawn and musical, and uttered most pertinaciously when you are near the nest. The males continue in song until the summer, ceasing in July and August, during the moult, and regaining it after that event, unlike any other of their kindred. 'The food of this species is largely composed of insects and larvæ, but small fruit and soft berries are eagerly sought as soon as ripe. The Willow Warbler pairs soon after its arrival, and eggs may be found from the end of April onwards to June. The nest is mostly made upon the ground, amongst sheltering herbage, but in exceptional cases it is placed at some distance above it. It is semi-domed, and made of dry grass, bits of moss, withered leaves, and roots, and lined with hair and large quantities of feathers. The five, six, or seven eggs are white (sometimes with a yellowish tinge), blotched, spotted, and freckled with pale brownish red. Parties of Willow Warblers are not unfrequently met with in the London area in autumn, on passage, and many seen here at that season and in spring are merely migrating over the city.

The adult Willow Warbler has the upper parts olivegreen, brightest on the rump; the paler eye-stripe is very ill-defined; the wings and tail are brown, with paler margins. The under parts are yellowish white, suffused with buff on the breast and flanks; the under surface of the wings and the metatarsi are yellow. Bill dark brown, paler below; tarsi and toes brown; irides brown. Length $4 \frac{3}{4}$ inches. The young are browner above and yellower below than their parents. 88 


\section{THE CHIFFCHAFF}

\section{PHTLLOSCOPUS RUFUS}

Local names in surrounding districts : "Oven-builder" (Essex).

Status in British Avifauna : A common if somewhat local summer visitor to England and Wales; most abundant in the south and west; rarer in Scotland and Ireland.

Radial Distribution within fifteen miles of $\mathrm{St}$. PAUL's: Although the Chiffchaff is almost as widely dispersed as the Willow Warbler it seems to be a scarcer and more local species in some localities. With this exception the distribution of the two species within the Metropolitan area is very similar. I do not find it so common or so well known in the eastern districts, and in the Epping area it is said to be a very local bird. During the seasons of its migrations it often visits the parks and wooded places within a mile or so of St. Paul's, but it probably breeds no nearer than Dulwich, or possibly in Battersea Park. Beyond this area it becomes so generally distributed in districts where the Willow Warbler is also found that it is unnecessary to repeat the list of localities. Very probably the two birds are much confused, although the very characteristic note of the Chiffchaff and its partiality for trees should form a ready guide to its correct identification. Passing mention may be made of a pair of Chiffchaffs that I watched for some time in the tall clm-trees in Kensington Gardens on April I3, I905worth recording as a date of passage.

Special interest attaches to the Chiffchaff, because it is absolutely the first, as it is the smallest, of the Warbler band to reach British shores in spring. True, its journey may not be a very extensive one, for possibly the south of France is the winter home of British individuals, but in any case the wild weather of the closing days of March usually 


\section{THE BIRD-LIFE OF LONDON}

brings this Warbler to the London area. March 16, 1906, is an exceptionally early record from Mitcham. The migration is stronger as April advances, and soon all the accustomed spots are filled. The return journey is equally a late one, and many examples of this species linger with us well into October. The bird soon proclaims its presence in a district by its monotonous so-called song, resembling the syllables chiff-chaff, which it utters with the greatest persistency at intervals the livelong day. Its general actions are very similar to those of its near ally the Willow Warbler, but the bird shows a more decided preference for trees, in this respect resembling its congener the Wood Warbler. It is an active, restless little bird, incessantly hopping about amongst the foliage, which it searches most industriously for its food. This chiefly consists of insects and larvæ. Upon one occasion I was intently watching a Chiffchaff searching an appletree for aphides, picking them off the under surface of the leaves, when it suddenly flew to the window and tried to catch a house-fly creeping inside the glass. It was most amusing to watch the bird fluttering before the windowpane, making repeated pecks at the glass in its efforts to catch the fly. To the above fare are added many small fruits. Soon after its arrival the Chiffchaff may be seen in pairs, and the breeding season extends over April, May, and June. Although fond enough of resorting to. the higher branches, it generally selects a site upon the ground for its nest, or at most a few feet above it, amongst ivy on a wall, or in a tangle of brambles and briars. A favourite spot is amongst the meadow-grass or tall herbage on a bank. It is semi-domed, and made externally of moss, dry grass and leaves, lined with hair and feathers. The half-dozen eggs are white, sparsely spotted with dark reddish brown, paler brown, and grey. The old birds are wary and secretive near the nest, and it is only by exercising great patience that one can induce them to betray 90 


\section{THE CHIFFCHAFF}

its precise whereabouts. The cock not unfrequently indicates the general locality by his persistent monotonous song in the branches near by.

The adult Chiffchaff has the general colour of the upper parts brownish olive-green, brightest on the rump; the greyish white eye-stripe is not very prominent; the wings and tail are brown, the outer margins of the feathers olive-green, the inner margins of the tail-feathers greyish. The under parts are yellowish white, merging into grey on the breast and flanks. Bill dark brown, paler below; tarsi and toes dark brown, nearly black; irides brown. Length about $4^{\frac{1}{2}}$ inches. The nestling resembles the parent, but is yellow on the under parts. 


\section{THE GOLDCREST}

\section{REGULUS CRISTATUS}

Local names in surrounding counties:

Status in British Avifauna: A widely distributed and common resident in all wooded districts, its numbers largely increased in autumn by migrants.

Radial Distribution within fifteen miles of $\mathrm{S}$ t. PAUL's: Although the Goldcrest is an irregular and fitful visitor to many places within strictly urban limits it does not appear to nest anywhere very near to the great city. I have seen it during autumn and winter well within a seven-mile radius, but know of no probable breeding-places nearer than Sydenham, Croydon, and the Wimbledon and Richmond districts in the south, Uxbridge, Harrow, Pinner, Wembley, and Epping in the west and north, and the Kentish Crays in the south-east. All observers testify to its most common occurrence during autumn and winter, and merely to specify the localities where it may probably be met with would be to compile a list of almost every wooded spot within the Metropolitan area from St. James's Park and Regent's Park outwards. One of its favourite resorts is Wembley, so far as my experience goes, and I cannot help thinking that it may nest in the many suitable spots in the park there. After all, the bird could easily be overlooked not only here, but in many other places within the fifteen-mile radius, its secretive and silent habits during the nesting season being very conducive to its non-discovery.

Although popularly regarded as "Wrens," the Goldcrests have only a remote affinity with those birds, their plumed nostrils and very conspicuous crest being two of their principal characteristics. 'The British Goldcrest is the smallest European bird, and there are many facts in its life-history of great interest. Not the least wonderful 92 

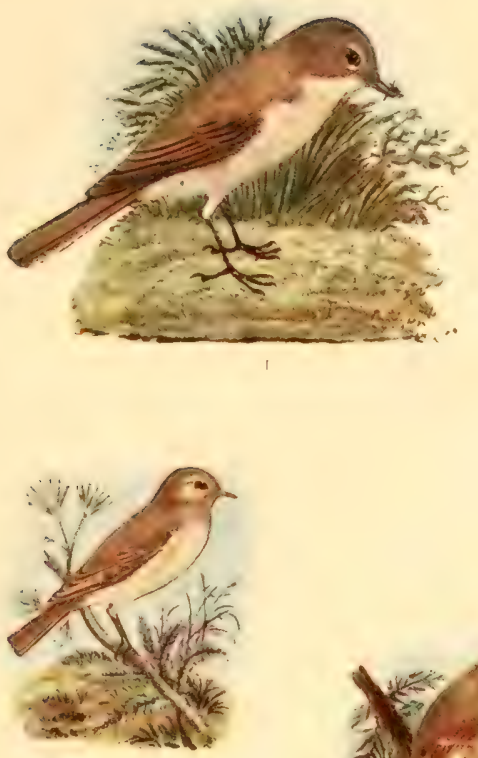
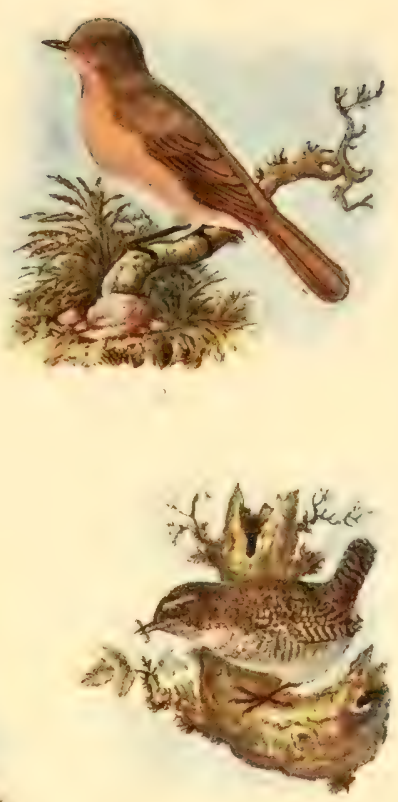
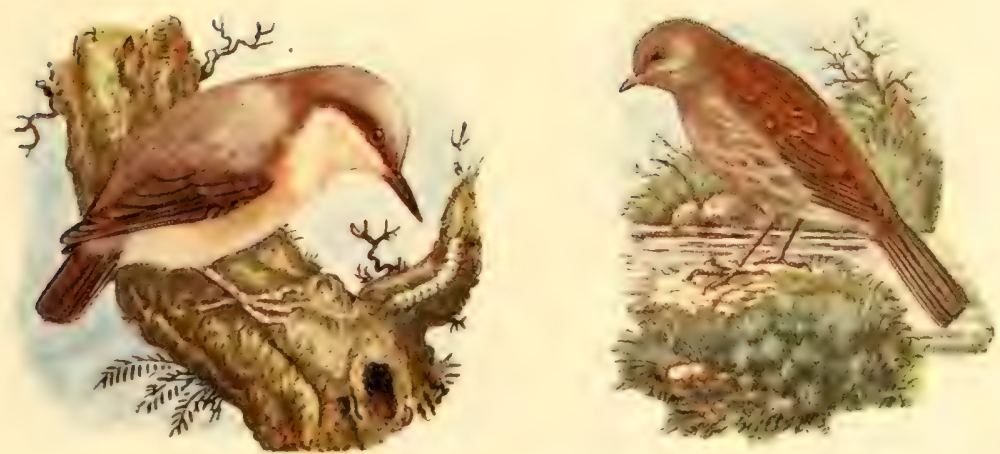

8. Whitethroat. 2. Dartford Warbler. 3. Willow Wren. 4. Common Wren.

5. Goldcrest. 6. Common Nuthatch. 7. Hedge Accentor. 



\section{THE GOLDCREST}

of these are its annual migrations. Many individuals of this species are apparently resident in our country, but in autumn these numbers are increased by vast hosts of Goldcrests from Continental Europe, and there can be little doubt that most of the birds seen in London are part of them. That the Metropolis is in the direct path of many migrating Goldcrests seems proved by the frequency of their occurrence during the season of migration; and it may be recalled with interest that an example was once found in the Great Wheel which used to stand in the Exhibition grounds at Earl's Court. I have seen this species myself in the trees in the gardens there. The Goldcrest is very Tit-like in its habits, not so much because of its affinity with those birds, but because it lives on similar food and searches for it in the same way and in the same places. It is by no means a shy bird, but its restlessness seldom allows one to observe it for long in the same spot. 'Tit-like, it explores the branches of the trees and clings to the slender twigs, searching the lower bushes, hidden in their tangled recesses, or for a fleeting moment appearing in view on the outer sprays; then flitting to the trees one after the other in a twittering, straggling train, uttering a singularly low and piercing call-note, pitched so high as to be absolutely inaudible to many ears. During summer the bird lives in pairs, but in autumn and winter consorts in parties, and very frequently accompanies Titmice in their wanderings. It subsists on insects, larvæ, and tiny seeds, those of the birch and alder being eagerly sought. It breeds in April or May, usually selecting a fir of some kind or a yew, from a branch of which it suspends hammock-wise its beautiful little, almost globular nest, the surrounding foliage being deftly interwoven with the materials. This is made of moss and lichens, bound together with cobwebs, and plentifully lined with hair and feathers. 'The six or eight eggs are pale reddish white, 


\section{THE BIRD-LIFE OF LONDON}

freckled with brownish red, chiefly on the larger end, and sometimes so suffused over the entire surface as to conceal the ground colour. During the breeding season the male has a sweet little song, but I have frequently heard this species warble delightfully in autumn. The young and their parents usually remain in company until the following spring.

The adult Goldcrest has the upper parts yellowish olive-green; two black lines reach from each side of the forehead, enclosing the flaming orange-yellow crest; the wings and tail are brown, with yellowish margins to the feathers, and the former have two white bars. The under parts are greyish brown. Bill dark brown; tarsi and toes brown; irides brown. Length nearly $3 \frac{3}{4}$ inches. The nestling has no black lines on the head, and the yellow crest is absent. 


\section{THE WREN}

\section{TROGLODTTES PARVULUS}

Local names in surrounding counties: "Diddy Wren," "Tiddley Wren" (Essex).

Status in British Avifauna: A common and widely distributed resident.

Radial Distribution within fifteen miles of St. Paul's: The Wren may fairly be described as a common resident throughout all suitable places in the Metropolitan area. The Wren's requirements are modest ones, and from the urban parks outwards through the increasingly rural suburbs to the remote open country on their furthest radius the restless little bird may be met with. I have heard its cheery carol within a stone's-throw of 'Trafalgar Square, on the island in St. James's Park, and in such spots as the Botanical Gardens, Kensington Gardens (near the palace), the grounds of Holland House, and many small patches of private ground at no great distance from the City. Like the Hedge Accentor, the Wren will often take up its quarters for the autumn and winter in some spot that affords it suitable cover, which it leaves in spring for a nesting-place further afield. Although mouse-like and skulking in its habits, its almost perennial song soon betrays its whereabouts in many localities where otherwise it would most probably be overlooked.

It is often matter for surprise how small a suburban garden or shrubbery will serve as a haunt for this species during many months of the year, the bird only quitting such a retreat to rear its young. The Wren is one of the most restless birds, not spending its activity up in the trees or bushes, but close to the ground, where it is for ever exploring every nook and corner, creeping about old walls, hedge-bottoms, the drifts of dead leaves, heaps of pea-sticks, or any other spots likely to harbour the "small 


\section{THE BIRD-LIFE OF LONDON}

deer" upon which it subsists. Its progress, with tail erect, is more like that of a mouse than a bird, and on the rare occasions when it flies far in the open it drifts along looking like a big brown leaf borne by the wind. During a lifetime spent in watching birds in almost every kind of circumstance I only remember to have seen the Wren bop upon the ground on one occasion. So unique was the experience that I recorded the date, March 3I, I897. I then saw a Wren cross a Deronshire lane for about half a dozen yards in a succession of rapid hops, from the hedge on one side to a low wall on the other. The Wren is a perennial songster. Except in the moulting season, in early autumn, its jorous, jerky, trilling song, loud and beatitully clear, stopfing with a suddenness that alwars seems to suggest that the singer has been interrupted before it could be finished, may be heard almost everywhere. I often pause for a moment to listen to it in the London farks. The callnotes are loud and startling, uttered in snatches in rapid succession, and most frequently heard when the bird is alarmed. Its food consists largely of insects, but also of seeds and fruits, according to scason. Except during the nesting season, and for a week or so after the young can fly, the IVren is solitary enough, although there can be little doubt that in many cases the birds fair for life and rearly breed in one particular spot. It is a somewhat early breeder, and eggs for the first brood may be found in April, those for later ones in June. The large, globular nest is made in bushes and thickets, amongst ivy on walls or tree-trunks, in old walls, in harstacks and sheds, in thatch, under banks, amongst tree roots, and on old irycovered stumps in the hedges. There are other sites more exceptional, but which possibly accur to many readers. The nest is made of moss, dry leares and grass, lichens, roots, and dead ferm-fronds, lined with hair and feathers. The entrance-hole is bound round with grass 96 


\section{THE WREN}

stems and roots. The external materials usually harmonise very closely with surrounding objects, and thus aid the concealment of the nest. The half-dozen or more eggs are white, spotted with brownish red and greyish brown. The IVren is a close sitter, but will forsake its nest with very little provocation.

The adult Wren has the upper farts dark rufous brown, darkest on the head, and barred from below the neck with dark brown; the wings and tail are rufous brown, barred with darker brown, the former spotted with white on the coverts; the eye-stripe is yellowish white. The under parts are rufous brown, shading into grey ish brown on the breast and throat, and more or less barred with dusky brown. Bill dark brown, paler brown below; tarsi and toes pale brown; irides dark brown. Length about $t$ inches. The nestling closely resembles the parents in general colour, but the under parts are a little more rufous. 


\section{THE C REEPER}

CERTHIA FAMILIARIS

LOCAL names in surrounding counties: "Bark-runner" (Essex).

Status in British Avifauna: A common and widely distributed resident in all wooded districts.

Radial Distribution within fifteen miles of $\mathrm{S}_{\text {t. }}$ Paul's: 'The Creeper is perhaps nowhere very abundant in any part of the Metropolitan area, but it is sufficiently widely dispersed therein to be fairly classed as a common bird in all places suited to its requirements. The bird, especially during winter, pays irregular visits to the urban parks where large trees are numerous. I have often watched its erratic movements about the trunks of the old elm-trees in Kensington Gardens and Hyde Park, in some of the old woodland fragments still remaining about Clapham and Dulwich, in the grounds of the Crystal Palace, and amongst the grand old oaks at Tooting. Possibly the Creeper breeds in none of these spots; I have no proof or record of the fact, but that it does so within a mile or two of these localities is certain. The bird breeds to my knowledge in Coombe Wood, in Richmond Park, at Wimbledon and Osterley, in the Willesden and Twyford areas, near Kingsbury and Harrow, Enfield, Waltham, Epping, and Wanstead. Across the Thames I have records of the species during the breeding season in the area of the Crays, Bromley, Croydon, Merton, Banstead, Kingston, and Epsom, but of course there are numerous intermediate localities where the bird habitually nests.

It requires a sharp and practised eye to detect the Creeper. Its unobtrusive ways conduce to its being overlooked. It is one of the most silent of our smaller birds, and it prefers to spend its life amongst the mature 98 


\section{THE CREEPER}

timber, where its sober colouring most effectually tends to its concealment. Woodpecker-like, it runs about the trunks and larger branches, supporting its body with its stiff tail, and picking out its food from the chinks and cracks with its long, slender bill. It flies little whilst in quest of food, save to move from one tree to another, and will often remain about one large tree until almost every part has been examined. Sometimes a solitary Creeper will join a company of Titmice during autumn or winter, and whilst its companions pick up a living amongst the slender twigs it will search the trunk for its own fare, but flitting off in company in an undulating manner. There are many old orchards in Greater London where the ways of this charming little bird may be watched with ease. It lives perhaps exclusively on insects and larvæ. The Creeper is not much of a songster, no more so than the Titmice, and its feeble call-note of weet is heard most frequently in the breeding season. It is solitary in its habits, seldom more than a pair being seen unless the brood is out, and very often but a single individual. It probably pairs for life, and begins nestbuilding for the first brood in April, for the second in June. A favourite site for its nest is in a crevice behind a piece of loose bark, but a hole in a tree is sometimes chosen, a cranny in a building or amongst thatch. The nest is made externally of twigs, lined with fine roots, strips of bark, moss, wool, and feathers. The six or eight eggs are yellowish white, spotted and blotched with reddish brown of various shades and grey. The old birds are secretive enough during the breeding period, and do little to betray the site of their nest, which may be placed in quite a frequented spot.

The adult Creeper has the upper parts dark brown, palest on the rump and darkest on the head, streaked with rufous brown and palest buff; the wings are dark brown barred with pale brown, the coverts tipped with pale 


\section{THE BIRD-LIFE OF LONDON}

buff; the tail-feathers are rigid, brown in tint, with yellow shafts. The under parts are silver-white, suffused with buff on the flanks and under tail-coverts. Bill dark brown, paler below; tarsi and toes brown; irides brown. Length about 5 inches. The nestling resembles the adult in colour, but has a shorter and nearly straight bill. 


\section{THE NUTHATCH}

SITTA CESIA

LOCAL names in surrounding counties:

Status in British Avifauna: A local resident, commonest in the southern and central English counties; rarer northwards, and accidental in Scotland; unknown in Ireland.

Radial Distribution within fifteen miles of St PaUl's: This handsome bird is fairly uniformly distributed over the Metropolitan area in all places suited to its needs, breeding in many localities and frequently visiting urban areas during the non-nesting season. It may be met with in almost every locality given for the Creeper, and precisely the same remarks apply to its errant wanderings. It often visits the lawns of suburban villas, has been noticed in Kensington Gardens, and I have on several occasions seen it on trees growing by the side of bus- and tram-frequented roads. It is said to breed at Dulwich, and I have records of it doing so at Richmond, Wimbledon, Nerton, Epsom, Banstead, and Croydon. In Middlesex it breeds at Osterley, Norwood, Hanwell, Harrow, and Wembley, and is often seen at Hendon, Hampstead, and Highgate, probably breeding in the latter locality. It is, of course, found at Epping and Wanstead, whilst across the river in Kent the Crays are a favourite resort, and Langley Park may also be mentioned. Beech woods and hazel coppices are favourite resorts of this species, but the bird wanders far and wide, and may be met with amongst every variety of timber, old parks being a great attraction.

Although more showy in coloration than the Creeper, the Nuthatch, from its retiring ways, is almost as much overlooked. It delights in precisely the same haunts, and has the same way of appearing accidentally in a spot 


\section{THE BIRD-LIFE OF LONDON}

perhaps not at all suitable to its requirements, where it will linger for a time. Parks full of old timber are the favourite haunt of the Nuthatch; orchards and less frequently large gardens are others. Although the tailfeathers are normal and soft the bird climbs about the trunks and larger limbs with perfect ease, and like the Woodpeckers taps the bark, and can break into a nut skilfully with its powerful, chisel-like bill. In two respects the Nuthatch is somewhat of an anomaly: he climbs with a soft tail, and has a bill like a Woodpecker, the latter structura. peculiarity being no indication of affinity with that bird, but only the result of similarity in obtaining food. Although an expert climber, the Nuthatch by no means confines itself to the trunks and larger branches, where it creeps about in every possible manner; it also frequents the slenderer boughs and twigs, and I have seen it clinging to the extremities of drooping ones, swinging like a pendulum whilst twisting off the fat farinaceous buds. 'The food of this species consists of insects, and larvæ also, as well as nuts-which are usually placed in some chink and chipped open with the bill-and various kinds of berries. It is somewhat solitary in habit, although paired for life, and frequently breeds in one spot for years. It has no song, but often betrays its presence by its vigorous tapping, and its call is a loud, musical whit. 'The Nuthatch probably rears more than one brood in the year, as eggs may be found as early as April and as late as July. 'The usual site for the nest is in a hole in the timber, less frequently in a wall or a haystack. 'The hole, which varies in depth from a few inches to a foot or more, is sometimes enlarged by the bird itself, and the entrance is invariably plastered up with clay, leaving an aperture just large enough for ingress, the amount of this material varying according to the size of the hole selected. At the bottom a slight nest of dry leaves and flakes of bark, sometimes a little dry grass, is formed, and here the six IO2 


\section{THE NUTHATCH}

or eight eggs are deposited. 'These are white, spotted with reddish brown and grey. The Nuthatch often makes its nest in a frequented spot in an orchard, and will continue to use the place in spite of much disturbance. Like all hole-builders it is a close sitter.

The adult Nuthatch is a very pretty bird, having the upper parts, including the two centre tail-feathers, the secondaries, and the margins of the primaries, clear bluegrey; the white eye-stripe and black band on each side of the head through the eye are very conspicuous; the wings are brown, the remaining tail-feathers black marked with white. The cheeks, throat, and centres of the under tail-coverts are white, the remainder of the under parts buff, shading into chestnut on the flanks and the margins of the under tail-coverts. Bill lead-colour, paler below; tarsi and toes pale brown; irides brown. Length nearly 6 inches. The nestling closely resembles the adult in general colour, but the under parts are not so rich a chestnut, none of the remaining tints are so brilliant, and the bill is much paler. 


\section{THE GREAT TITMOUSE}

\section{PARUS MAFOR}

Local names in surrounding counties : "Saw-sharpener," "Post-builder" (Essex).

Status in British Avifauna: A widely distributed and common resident in all wooded districts; numbers increased in autumn by migrants.

Radial Distribution within Fifteen miles of $\mathrm{S}_{\mathrm{T}}$. Paul's: Although nowhere so common as the Blue 'Titmouse, the present species is pretty generally distributed over the Metropolitan area, and as a transient visitor may be met with in the central portion. It is a frequent visitor to St. James's Park, the grounds of Buckingham Palace and Marlborough House, Hyde Park, and Kensington Gardens, to my knowledge breeding in the two latter. Thence it may be traced as a visitor (and possibly nesting) to the grounds of Holland House, north to Regent's Park, east to Victoria Park. On the "Surrey side" I can record it from Peckham Rye, Herne Hill, Battersea Park, and Clapham Common. Beyond these limits its distribution becomes so general that a detailed list of localities is scarcely necessary. As the suburbs become more rural and vegetation more abundant it becomes commoner as a nesting species, sometimes rearing its young year by year in situations close to public highways. The bird is not so gregarious as the smaller species of Tits, and very often an odd individual attaches itself to a party of them. It moves about a good deal in pairs, and is warier than many of its congeners.

There can be little doubt that many of the Great Tits seen within the London area, especially during autumn and winter, are migrants from Continental Europe, or perhaps from more northern localities in our own island. IO4 


\section{THE GREAT TITMOUSE}

At these seasons the Great Tit may be seen or heard in gardens, in trees by the wayside, even in busy streets, especially such as may be in the vicinity of the parks. During the breeding season, however, the bird retires to more suitable haunts, and also does not betray its whereabouts to any great extent by its characteristic notes. The habits of all the Tits are very similar; the birds spend most of their waking moments amongst the branches in quest of food, restlessly hopping hither and thither, placing themselves in every possible attitude, some grotesque in the extreme, and from time to time trooping off one after the other in dipping flight. Of all the British species perhaps the Great 'Tit is the wariest, and it confines itself more to the larger trees than its congeners. It lacks the audacity of its ally the Blue Tit, and seldom or never evinces such trustfulness in man. Sometimes, however, it visits the ground to search for food, and frequently clings to the bark, hammering with its stout bill to get at some tempting morsel. Insects and larvx and small seeds and fruits form the principal food of this Titmouse, but exceptionally a small bird is killed after the manner of the Shrike. The bird is not much of a songster, but in early spring the males string a few notes together into the semblance of a love-trill, and at this season especially its shrill call of peek-ur, peek-ur, is very characteristic. Besides these it often utters a musical sisi-si or a spluttering and prolonged chur. 'The Great Tit pairs for life, and preparations are made for its first brood in April; in June for a later one. It makes two distinct types of nest, according to the situation in which each is placed. One is globular, almost like that of the Wren, and made in the old nest of a Crow or a Magpie, or amongst the sticks of that of a Rook, even whilst it is occupied; the other is open and placed in a hole of a wall, a tree, a pump, post, flower-pot, or even in the ground. The materials are moss, dead leaves, dry grass, hair, wool, and 


\section{THE BIRD-LIFE OF LONDON}

feathers, more or less felted together, the first-named type, of course, being the most compactly made. The six or eight eggs are white or yellowish white in ground colour, spotted and freckled with light red. Throughout the nesting season the old birds are shy and wary and silent.

The adult Great 'Titmouse has the general colour of the upper back yellowish green, yellowest towards the nape, which is white, and shading into slate-grey on the lower back and upper tail-coverts ; the forehead, crown, sides of the neck and throat are glossy black, the cheeks and the ear-coverts are white; the wings are brown, with pale margins, the coverts pale blue, tipped with yellowish white, forming a bar; the tail is dull black suffused with blue, the two outer feathers white along the outer web and at the tip, the next pair tipped with white. The under parts below the throat are bright greenish yellow, with a broad black band extending from the black on the throat to the vent, which, with the under tail-coverts, is mottled with white. Bill black; tarsi and toes lead-colour; irides dark brown. Length $5 \frac{x}{2}$ inches. The nestlings closely resemble their parents in general colour, but are duller, and the white parts are suffused with yellow. 


\title{
THE BLUE TITMOUSE
}

\author{
PARUS CARULEUS
}

Local names in surrounding counties: "Pick-cheese," "Bluecap" (Essex).

Status in British Avifauna : A common and widely distributed resident in all wooded districts, its numbers increased in autumn by migratory individuals.

Radial Distribution within fifteen miles of $\mathrm{S}$ t. PAUL's: This is the commonest and by far the best known of the Tits throughout the Metropolitan area. It may be met with from time to time almost anywhere, provided there are a few trees to afford it shelter. So grimy does the little bird become in exploring the sootcovered trees that one is often puzzled for a moment to recognise it, its delicate contrasts of blue and yellow being concealed by the dirt of the great city. It probably breeds from St. James's Park outwards to the limits of our radius, including almost every urban park in the Metropolis. In winter there are few private grounds or houses with trees about them that the Blue Titmouse does not visit, and its cheery notes may often be heard from the trees that fringe suburban roads, or even the Thames embankments. It is possible that some of these little wanderers may be migrants, for the species is particularly in evidence in autumn, when the countryside is swarming with family parties not only from our own woodlands, but from across the seas, whither they come in company with Goldcrests and the following species.

Next to the Sparrow and the Starling the Blue Titmouse is one of the most familiar of London's birds. Although it seems to go into an eclipse, as it were, during the breeding season, kecping silent and seclusive, during the remainder of the year it is in more or less constant evidence. Never is it more so than in autumn, when crowds 
of this species visit us from other areas and in noisy bands invade the trees and gardens. Often the little blue mites may be watched from our windows, searching the chrysanthemum bushes and the tall, fast-withering sunflowers, or actively flitting about the trees, clinging in every attitude to the slender extremities of the twigs, and answering each other with merry twittering cries. Then a bone or bit of suet hung in the back garden, be that garden ever so small, will attract the Blue Tit almost without fail, and the tiny visitor will afford endless amusement by its acrobatic movements as it picks a meal. It is one of the most nimble of birds, and may often be seen holding a big seed or a scrap of suet in its feet the better to tear it in pieces with its strong bill. The way it will bore into an apple or a pear is astonishing. The food of this Titmouse consists of insects and larvæ, small seeds, fruit, and any unconsidered trifles of animal matter that come its way. In the pairing season more especially it may be heard to utter a string of twittering notes, something like chicka-chic-ka-kee-kee-kee. Its call-note is an oft-repeated si-si-si, and when disturbed at the nest it hisses in a most alarming way. The Blue Titmouse seems to pair for life, and will yearly return to nest in a certain spot. It is double-brooded, laying in April and June. Its nest is invariably made under cover, in a hole of some kind, in a tree, wall, post, stump, flowerpot, pump, or other singular spot, more rarely in the ground itself. It is a carelessly made cup of moss, dry grass, and leaves, matted together with wool and hair, and lined with feathers. The six to ten eggs are white, freckled and spotted with light red. It is a courageous little creature at the nest, and will bite fiercely in defence of its home.

The colours of the Blue Titmouse are distributed in a somewhat eccentric way. The adult has the general colour of the upper parts from the nape yellowish green ; I08 


\section{THE BLUE TITMOUSE}

the wings and tail are blue, the greater wing-coverts and the innermost secondaries tipped with white; the crown is azure blue, surrounded by a ring of dull white, succeeded by a band of dark blue, which also encircles the white cheeks and meets on the chin and throat. The under parts below the throat are greenish yellow, palest on the abdomen, and with a streak of dusky blue on the centre of the breast; under surface of the wings yellow. Bill dusky grey; tarsi and toes lead-colour; irides brown. Length $4^{\frac{T}{2}}$ inches. The nestling is similarly coloured, but the white parts are strongly suffused with yellow. and the dusky mark on the breast is absent. 


\section{THE COAL TITMOUSE}

\section{PARUS ATER (sub-sp. BRITANNICUS)}

LoCAL names in surrounding counties:

Status in British Avifauna: A widely distributed resident in all wooded districts, its numbers largely increased in autumn by migrants.

Radial Distribution within fifteen miles of $\mathrm{S}_{\mathrm{T}}$. Paul's : 'The Coal Titmouse is another of those species that is generally met with in the immediate precincts of the city during the autumn and winter. It is, however, by no means as common in the Metropolitan area, apparently, as the two preceding species, and many of the individuals that pay London a visit are doubtless autumn migrants from Continental localities. I have records of the Coal 'Titmouse as near the city limits as St. James's Park, Hyde Park, Kensington Gardens, Regent's Park, Holland Park, and Battersea Park. That it also pays fitful and fleeting visits to many other spots where trees grow within the inner portions of the great city is undoubted. In the outlying suburbs the bird, of course, becomes of more frequent occurrence. It is recorded as breeding at Dulwich and Norwood, and to these localities may be added Tooting and Clapham. Elsewhere it certainly breeds in the Kew, Richmond, and Wimbledon districts, at Bushey, Hounslow, Osterley, Hanwell, Horsenden, Twyford, Wembley, Harrow, Kingsbury, and Elstree. It also nests in the Epping area, Wanstead, in the Kentish Crays, and in the Croydon, Banstead, Epsom, Merton, and Cheam districts.

Precisely similar remarks apply to the Coal Titmouse as to the preceding species, although the bird is a much scarcer one, and not so familiar and trustful as the lastnamed. Its habits are very similar; in autumn and winter it becomes more or less gregarious and social, in summer living I 10 


\section{THE COAL TITMOUSE}

in pairs. Its food consists chiefly of insects, larvæ, and small seeds. It has the usual Tit-like actions, restless and acrobatic, and frequently consorts with other 'Tits, Nuthatches, and Creepers, from which its loud, clear note of if-bee-ifbee-if-bee serves instantly to distinguish it. In winter it often visits houses in the suburbs, and shares the suct or bone with the Blue Tit. It rears two broods in the year, laying in April and June. It appears to pair for life, and often returns regularly to one spot to breed. The nest, a somewhat slovenly, loosely constructed cup of moss and dry grass, felted together with hair and lined with feathers, is placed in a hole of a tree or wall, in a pump, or even at times in the ground. The six or eight eggs are white, spotted and freckled with red.

The adult Coal 'Titmouse has the head and throat rich glossy black shot with blue, the cheeks and nape white, the remainder of the upper parts brown; the wings and tail are greyish brown, the coverts of the former tipped with white, making a double bar across them; the breast and remainder of the under parts are greyish white, shading into brown on the flanks. Bill black; tarsi and toes lead-colour; irides brown. Length $3 \frac{3}{4}$ inches. The young resemble their parents, but the white parts are replaced by sulphur-yellow. 


\section{THE MARSH TITMOUSE}

\section{PARUS PALUSTRIS}

Local names in surrounding counties: "Blackcap" (Essex).

Status in British Avifauna: A locally distributed resident in all suitable districts of England, Wales, and the south of Scotland; rarer and more local in Ireland.

Radial Distribution within fifteen miles of $\mathrm{S}_{\mathrm{T}}$. Paul's: The Marsh Titmouse is decidedly more local than any of the preceding species, although, given suitable localities, it is by no means an uncommon bird within the Metropolitan area. It may be met with occasionally in almost every spot where there are trees, chiefly during autumn and winter, and these wanderings embrace probably every spot visited by its three congeners. From St. James's Park and the Green Park outwards it is a winter straggler, and may possibly breed in Regent's Park and in the vicinity of Kilburn, in both which places I have seen it in summer. As we get out more into the rural suburbs the bird is better known, and in many places breeds regularly. It is recorded as doing so at Dulwich, possibly in Battersea Park, and thence in all suitable localities to the limits of its London distribution. It is certainly local at Epping, but I note it as a resident at Kingsbury, Stanmore, and Elstree, possibly at Hampstead, and certainly in the Wembley and Harrow areas." It may also be met with during summer at Southall and Ealing, Harlesden, and about the wooded districts west of Wormwood Scrubbs. In Kent and Surrey it is also fairly numerous.

There can be little doubt that the Marsh Titmouse is very frequently confused with the Coal Titmouse, and consequently thought to be scarcer in the London area than is actually the case. Its actions are very similar ; it. I 2 

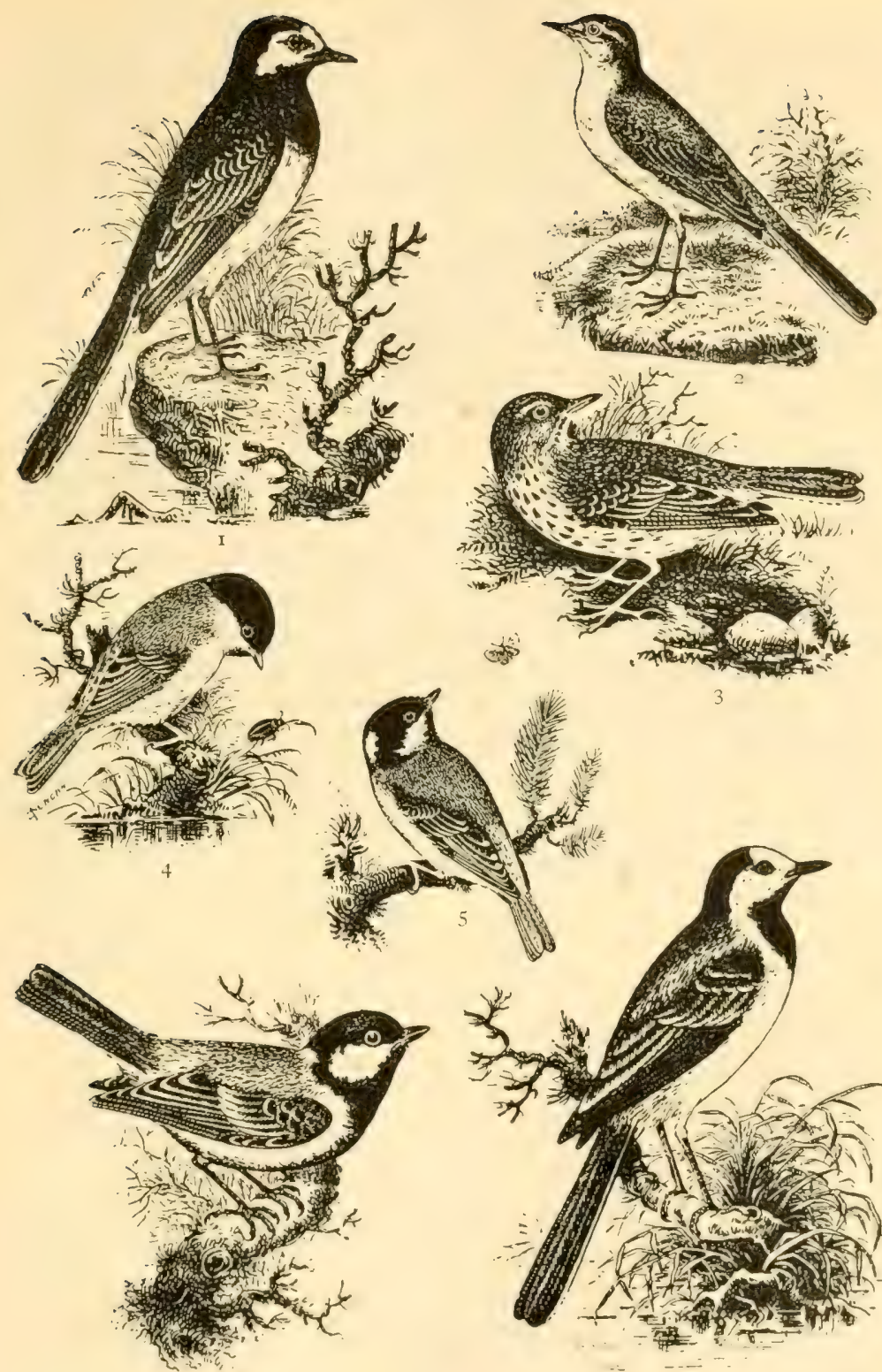



\section{THE MARSH TITMOUSE}

feeds upon much the same objects; but its characteristic cry of tay-tay-tay will readily serve to identify it, in conjunction with the absence of a white nape. The Marsh Titmouse appears to pair for life, and rears two broods in the season, the eggs for the first being laid in April, those for the second in June. A hole in a decayed stump or tree, sometimes in a gate-post, is usually selected, and in this a nest is made, cup-shaped, of dry grass, moss, wool, hair, and feathers, matted and felted together. The six to ten eggs are white, spotted and freckled with brownish red. After the young are hatched the birds keep in family parties for some time at least, although the Marsh Titmouse is perhaps the least sociable of all the Tits.

The adult Marsh Titmouse has the crown of the head and the nape glossy black, the cheeks white, the remainder of the upper parts sandy brown, palest on the rump; the wings and tail are brown. The chin and upper throat are black flecked with greyish white, the remaining under surface greyish white, suffused with buff on the flanks and vent. Bill black; tarsi and toes lead-colour; irides brown. Length $4^{\frac{x}{2}}$ inches. The nestling closely resembles the parents in colour, but the black portions of the plumage are not so glossy, and the under surface is paler. 


\section{THE LONG-TAILED TITMOUSE ACREDULA ROSEA}

Local names in surrounding counties: "Bottle-Tit," "Oven-Tit," "Pudding-Poke," "Bottle-Tom" (Essex). Status in British Avifauna: A common and widely distributed resident in wooded districts, becoming more local in Scotland and Ireland.

Radial Distribution within fifteen miles of $\mathrm{S}_{\mathrm{T}}$. PAul's: This pretty bird is another fitful visitor during autumn and winter to the innermost parts of the Metropolis, more frequently observed in private grounds, shrubberies, and enclosures of small trees than amongst the larger timber. There are few such spots in which it may not be met with from Kensington Gardens, Regent's Park, and Battersea Park outwards. As the suburbs become more rural and well-shrubbed grounds more plentiful the Long-tailed Titmouse may be observed more frequently. How close to the city it actually nests it is perhaps difficult to say. It is recorded as doing so at Dulwich, and very possibly in the 'Tooting and Norwood districts. It certainly breeds at Wimbledon and Richmond, Bushey, Hounslow, and Osterley, whilst northwards I trace it through Ruislip Woods, Pinner, Horsenden, Sudbury, and Wembley. It also nests in the districts of Harrow, Mill Hill, Barnet, Enfield, Waltham, Epping, Wanstead, and Ilford, and across the river in the Crays, Bromley, Beckenham, Croydon, Carshalton, and Sutton. In the more remote districts it is of course more generally dispersed, and in many cases nests in comparatively public spots.

Of all the British species the Long-tailed Titmouse is the most restless and wandering in its disposition. Except during the breeding season, the birds in parties are roaming the countryside, and only appearing fitfully in II 4 


\section{THE LONG-'TAILED 'TITMOUSE}

any one locality. There are few prettier sights than a company of Long-tailed Tits, especially in winter, when the bare trees admit of their close observation. 'They are most sociable little birds, keeping close together, trooping in dipping flight one after the other from tree to tree or along the hedgeside, twittering merrily to each other. Their actions are much the same as those of the other Titmice, but their long tails give an added grace to their acrobatic movements. They feed chiefly upon insects, especially in summer, but at other times small seeds are sought. The broods and their parents usually keep company through the winter, but in early spring these break up into pairs for nesting duties, and the old birds appear to return to some old-accustomed spot to rear another family. The notes of this species are not so varied as those of other Titmice, the usual call being a harsh, churring string of cries, besides which the bird utters the usual si-si-si prevalent with all. The Longtailed Titmouse is famous for the beautiful nest it builds, a large, globular structure which for compact workmanship is unexcelled. Contrary to all the other British species of Tit, the present bird places its home in a low tree or bush, amongst thickets, in evergreens, or in a cluster of honeysuckle. It is usually made chiefly of moss and lichens, cemented together with cocoons and spiders' webs, and lined with an abundance of feathers and hair. Usually one or two twigs are interwoven, and the entrance-hole is on one side near the top. The outer materials often harmonise most closely with surrounding objects. The six to ten eggs are white, dusted with pale red and grey.

The adult Long-tailed Titmouse has the head white, the crown encircled with a black band; the back is black, shading into rose-pink on the rump and scapulars; the wings are black, the innermost secondaries with broad white margins; the long tail is black, the three outermost feathers on each side white on the outer web and on part 


\section{THE BIRD-LIFE OF LONDON}

of the inner web at the tip; the cheeks and throat are greyish white, with dusky streaks on the fore-neck; the remainder of the under parts is pale rosy pink; under surface of the wings white. Bill black; tarsi and toes dark brown; irides brown, eyelids red. Length $5 \frac{\pi}{2}$ inches. The nestling is duller in colour than the adult, and lacks most of the rosy tints. 


\section{THE PIED WAGTAIL \\ MOTACILLA YARRELLI}

Local names in surrounding counties : Nanny Wagtail,"

"Dish-washer" (Essex).

Status in British Avifauna: A common and widely distributed resident, becoming more local in winter, and subject to some migrational movement.

Radial Distribution within fifteen miles of St. Paul's: The Pied Wagtail seems to possess a special propensity for paying casual visits to most uncongenial places in towns and cities. Many years ago I used frequently to see this Wagtail in the most central parts of Sheffield, running along the roofs of the factories or daintily tripping by the margin of the filth-stained rivers, an arm's-length from roaring machinery. In London I have many times noticed it running about the foreshore between the Tower and Battersea. It may well be described as one of the commonest of our country's birds, and has been known to nest in suitable spots right up to the town limits. These include most of the parks and the suburban brickfields. There are, indeed, few localities where water is present that this Wagtail does not visit; and this means that the bird may be met with all along the Thames, by the various canals and the many ornamental sheets of water and reservoirs that abound in the Metropolis. I have no personal records of the species from the fountains in Trafalgar Square, but the bird has been seen at them. In all the more rural suburbs it is of frequent occurrence, and breeds in every locality at all suited to its needs.

The Pied Wagtail is subject not only to much local movement, but to considerable migration during autumn and spring; consequently many individuals on passage visit inner London, seldom remaining long, and by no 


\section{THE BIRD-LIFE OF LONDON}

chance attempting to breed. This Wagtail is by far the best known of the five species that nest in the British Islands, and is one of the most lively and graceful of birds. It may not only be seen by the waterside, but running daintily about the market-gardens and suburban fields where tilling work is in progress, or in the pastures where cattle are grazing. It is ever in movement, and its long tail is being almost incessantly beaten up and down, as if to balance the body. It runs lightly over the earth, occasionally darting this way or that to snap at a fly, or flutters into the air on a similar quest. If disturbed it flies off in a peculiar dipping way, each dip accompanied by its callnote of chiz-zit. The moment it settles again the long tail is rapidly beaten several times in succession, and then the sylph-like little creature renews its running to and fro. Water is ever an attraction to this Wagtail, the sluggish streams like the Brent and the Mole, the open ditch, beneath the dignity of a name, the stagnant pool in the brickyard, or the horse-pond by the roadside or in the corners of the field, all present rich feeding-grounds for the Pied Wagtail. Its food consists almost exclusively of insects and their larvæ, together with small worms and snails. The cock bird has a song, but only utters it at rare and fitful intervals in the love season, and usually when hovering for a moment or so above his mate, less frequently on the ground or from a tree, where, however, he is rarely seen. The song is short, varied, and musical, somewhat resembling the twittering music of the Swallow. The Pied Wagtail is an early breeder, eggs for the first brood being laid in March, and for succeeding broods onwards to June. It is probable that many birds of this species pair for life, as year after year nests may be found in the same spots. The nest, amongst a variety of similar situations, is often made in a hole of a wall, under a clod of clay or a tile, and is a large, cup-shaped structure, formed of dry grass, straws, twigs, moss, or, in fact, almost I I 8 


\section{THE PIED WAGTAIL}

any dead vegetable refuse, lined with hair, wool, and feathers. The five or six eggs are greyish white, freckled and spotted with pale brown and grey, and occasionally scratched with dark brown. The young keep in company with their parents for some time, and many of the later broods remain together through the winter, during which season the bird is more or less gregarious.

The adult male Pied Wagtail in summer plumage has the upper parts black, except the forehead, ear-coverts, and the sides of the neck, which are white; the wing-coverts are marked with white, and the inner secondaries and two outside tail-feathers are white; the other wing and tailfeathers are black. The throat and upper breast are black, which joins the black of the upper parts at the shoulder and isolates the white on the sides of the neck from the white of the remainder of the under parts. Bill black; tarsi and toes black; irides brown. Length about $7 \frac{\text { T }}{4}$ inches. The female in similar plumage resembles the male, but the colours of the upper parts are never so pure, and mottled with grey. The nestling is nearly uniform grey, and after the first moult the white parts then assumed are suffused with yellow. In winter plumage the adult has a white throat, and the black on the breast is represented by a crescentic band; the back is grey, and the nape black. 


\section{THE WHITE WAGTAIL \\ MOT ACILLA ALBA}

Local names in surrounding counties:

Status in British Avifauna: A local visitor, chiefly on spring and autumn migration, a few remaining to breed; rare in Scotland, and very sparingly distributed in Ireland.

Radial Distribution within fifteen miles of St. PaUt's : A special interest attaches to the White Wagtail, for it was first noticed in England in the spring of $\mathrm{I}$ 84 I by Bond, who discovered it breeding at Kingsbury Reservoir, which is less than eight miles from St. Paul's. There can be no doubt that the present species is very often confused with the Pied Wagtail, so that even its approximate dispersal within the Metropolitan area becomes very difficult to trace. That it visits many parts of this area during its annual migrations cannot be doubted; whether it habitually nests within it cannot at present be determined. Mr. Sharpe records the visit of this Wagtail to Chiswick in October 1890 and I89I. The comparatively few observers competent to identify the White Wagtail in this area renders its detection a matter of the greatest chance. That the White Wagtail breeds in England far more frequently than was once suspected by ornithologists, as the recent testimony of careful observers proves, seems to suggest the bird's greater frequency within our limits. The information relating to this species round London is exceptionally meagre, and the Kingsbury and Chiswick records stand practically alone. Let us hope that a fuller investigation may soon be made and recorded.

The habits, nesting economy, and eggs of the White Wagtail so closely resemble those of the preceding species that it is not necessary in a work of the present scope to I 20 

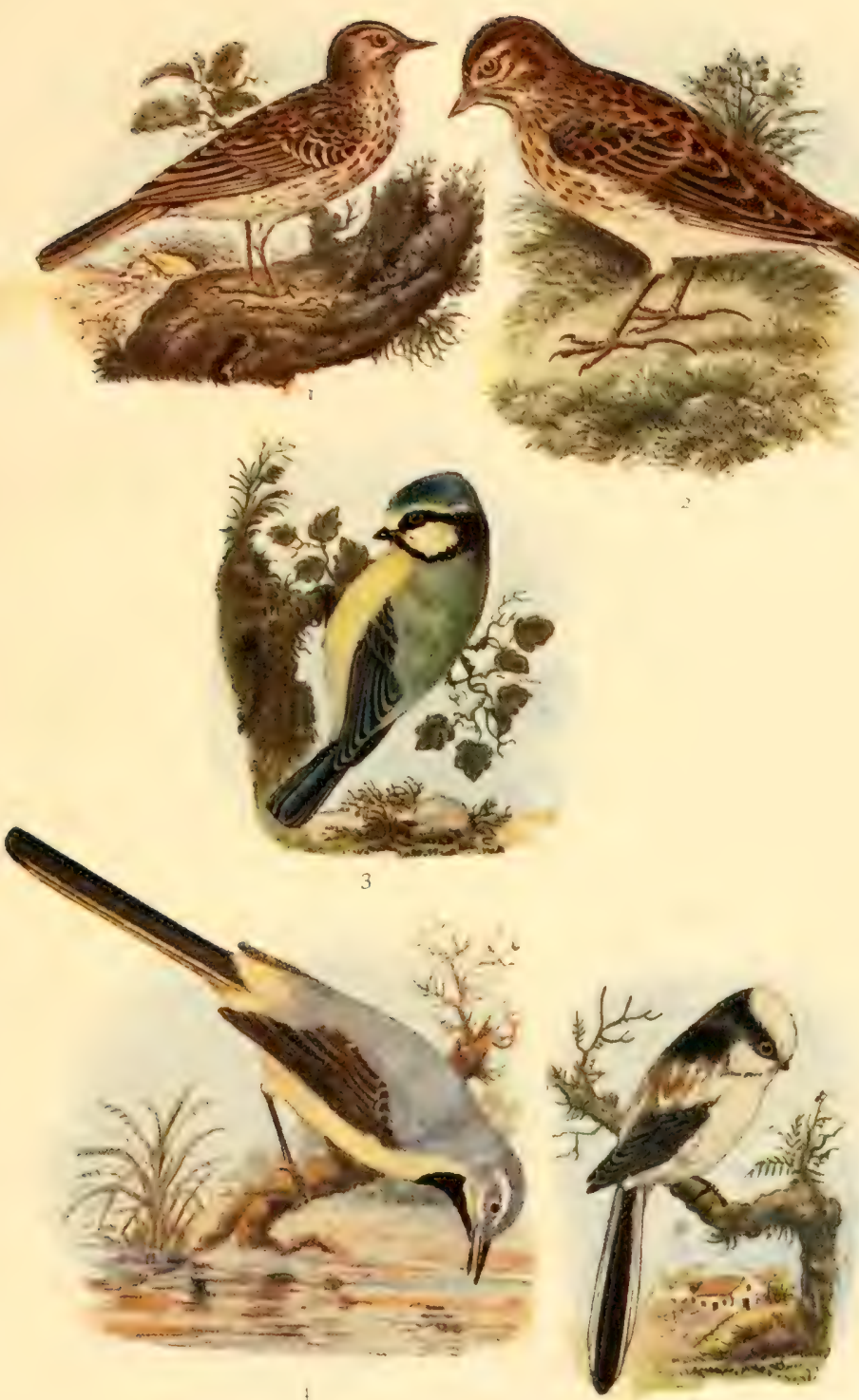

r. Tree Pipit. 2. Skylark. 3. Blue Titmouse. 4. Grey Wagtail.

5. Long-tailed Titmouse. 



\section{THE WHITE WAGTAIL}

specify them. A more useful purpose will be served in devoting our allotted space to the points of distinction between the two birds.

The White Wagtail in breeding or summer plumage may always be distinguished from the Pied Wagtail, which it otherwise very closely resembles, by its slategrey, instead of black, back. In winter plumage the two species are very much more alike in colour, but in the Pied Wagtail the rump is always darker than that of the White Wagtail, the latter having the upper tail-coverts dark only.

It is interesting to remark that the White Wagtail is common enough just across the English Channel, in the meadows near Calais, actually within sight of our island, where, however, it is a rare and local species. The two species have been known to interbreed, and in the South Kensington Museum a nest from Norfolk is exhibited, the male belonging to which is a White Wagtail and the female a Pied Wagtail. Another instance has been recorded from Suffolk. 


\title{
THE GREY WAGTAIL
}

\author{
MOTACILLA SULPHUREA
}

Local names in surrounding counties:

Status in British Avifauna: A somewhat locally and sparingly distributed resident throughout England, Wales, and Ireland; more commonly dispersed in Scotland. It is subject to considerable local or internal migration, in summer frequenting the moors, mountains, and uplands, in winter the plains and low-lying grounds.

Radial Distribution within Fifteen miles of $\mathrm{S}_{\mathrm{T}}$. Paul's : The Grey Wagtail is occasionally met with between autumn and spring in suitable spots well within the inner portions of our radius. From Chelsea upwards it pays irregular visits to the banks of the 'Thames, and I have a record of it from the filter-beds at Battersea; another from St. James's Park. I have also seen it on the banks of the Brent between Hanwell and Brentford, as well as on those of the Wandle during winter. It is also a winter wanderer to Kingsbury Reservoir, the Welsh Harp, Hampstead Ponds, Muswell Hill, and the Epping, Wanstead, and Dagenham districts. I have a summer record from the banks of the Beverley Brook at Wimbledon, and I believe the nest was taken at Barnes Common some dozen years ago. Its breeding within the Metropolitan area, however, must be very exceptional, but its casual visits at other times are sufficiently numerous and widely dispersed to call for no very special remark nor record.

The Grey Wagtail is more addicted to the waterside than any other British species of the group, and always prefers a mountain stream to a lowland one, but in autumn many of the northern waters are deserted, and then the bird appears near rivers and pools in the milder south. It is chiefly during this internal migration from the low- 


\section{THE GREY WAGTAIL}

lands to the hills that the Grey Wagtail visits the London waters. Its habits are very similar to those of the Pied Wagtail. It runs in the same easy, graceful way, accompanies its movements with the same beats of the long tail, has the same peculiar dipping flight and a similar call-note during its progress, feeds on insects, larvæ, small worms, and seeds, and young and parents keep in parties for long after the former can forage for themselves. Its song is fitful, but of the same twittering character, and the bird frequently perches in trees. It may rear more than one brood in the year, as eggs are found from April to June. The nest is never made far from the waterside, under an overhanging rock or bank or stone, or among tall grass and weeds, sometimes an old stump. It is made of dry grass, roots, and moss, lined with hair and sometimes feathers. The four or five eggs are white, more or less tinged with grey or buff, mottled and speckled with pale brown, and occasionally scratched with dark brown.

The adult male Grey Wagtail in summer has the upper parts slate-grey, shading into greenish yellow on the rump and upper tail-coverts; a white stripe extends from the base of the bill behind the eye ; the wings are dark brown, with pale margins, the secondaries with the basal half white. The central tail-feathers are brownish black, with yellowish margins; the two outer ones are white, the succeeding pair white on the inner web, most of the remaining portion dull black. A narrow white line extends from the base of the bill down the sides of the throat and upper breast, which are black, and the remaining under parts are bright yellow. Bill black; tarsi and toes brown ; irides brown. Length $6 \frac{3}{4}$ inches. The female closely resembles the male in colour, but the black throat is mixed with grey. The nestling closely resembles the adult in autumn plumage, in which the black throat is replaced by white. 


\title{
THE YELLOW WAGTAIL
}

\author{
MOTACILLA RAII
}

Local names in surrounding counties:

Status in British Avifauna: With few exceptions, a summer migrant, generally distributed over England and the south of Scotland, but very local in Ireland, chiefly in the north and west.

Radial Distribution within fifteen miles of $\mathrm{S}_{\text {t. }}$ Paul's: This beautiful and graceful little bird is chiefly observed during the two seasons of migration within the Metropolitan area, although a small number pass the summer in suitable parts of it. I have seen this species in the Green Park, in Hyde Park, in Regent's Park, and Battersea Park. There must be various other similar spots which it frequents occasionally. Further out towards the more rural suburbs its occurrence, of course, becomes less noteworthy. It occasionally visits Wormwood Scrubs, many of the large market-gardens and sewage-farms, and most of the open pieces of agricultural land still left between the blocks of houses. The Yellow Wagtail has been known to breed at Putney, Wandsworth, and Mitcham. It also does so commonly in the Wimbledon and Richmond districts, as well as in those of Hanwell, Southall, Sudbury, Wembley, Harrow, Hendon, Enfield, Waltham, and Epping, although in the latter locality it is said to be becoming less numerous. Thence it may be traced as a breeding species through many places in the eastern suburbs, in Kent, and in all suitable parts of North Surrey, from Epsom and Chelsham inwards.

The gay and sprightly Yellow Wagtail is pre-eminently a bird of the open fields and pastures, most in evidence, perhaps, shortly after its arrival upon ground which is being tilled, and where it may be seen daintily running I 24 


\section{THE YELLOW WAGTAIL}

after the plough, standing for a moment on some clod of carth, and all the time vigorously beating its long tail up and down in the usual Wagtail-like way. Flocks of this Wagtail reach our shores in March, and for some little time after their arrival continue together, ultimately distributing in pairs over the usual summer haunts. In the autumn similar habits are noticed, and during September and October the journey south is made in companies. The habits of this species are very similar to those of allied forms. The bird is mostly terrestrial, seldom perching in trees, but occasionally soaring in a Pipit-like way to utter a short, twittering song. It moves from place to place in the same dipping flight as its congeners, accompanying it with a series of shrill chiz-zits, is by no means shy, and is very partial to running about the pastures where cattle are feeding to prey upon the many flies that assemble near them. The food of this species is chiefly composed of insects and larvx and small worms. It may rear two broods in the season, the first in April, the second in June. It pairs soon after arrival, and makes its nest on the ground, well concealed amongst herbage or under a stone-or clod of earth. The outer materials are chiefly dry grass, roots, and moss, the lining of hair, fur, and feathers. The five or six eggs are greyish white, mottled and speckled with various shades of olive, and occasionally streaked with dark brown. The young are tended after they leave the nest, and the broods join into larger companies as the autumn approaches. I ought to add that the Yellow Wagtail is to some extent a winter resident in this country.

The adult male Yellow Wagtail in breeding plumage has the general colour of the upper parts yellowish green, and the under parts, including a stripe over the eye, are bright yellow. "The wings and tail are similar to those of allied species. Bill black; tarsi and toes black; irides brown. Length about $6 \frac{\pi}{4}$ inches. The female closely 


\section{THE BIRD-LIFE OF LONDON}

resembles the male in colour, but is a trifle duller, and the forehead is not so brilliant a yellow. The autumn plumage is greener than that of summer. The nestlings are browner above, the eye-stripe is buff, the throat and chest are suffused with buff, and there are many dusky spots on the latter. 


\section{THE TREE PIPIT \\ ANTHUS ARBOREUS}

Local names in surrounding counties:

Status in British Avifauna: A widely distributed summer visitor, rarer in the west of England and in Scotland, and almost unknown in Ireland.

Radial Distribution within fifteen miles of $\mathrm{S}_{\text {t. }}$ Paul's : 'The Tree Pipit is still a fairly common if somewhat local summer visitor to the suburbs of London. It is a bird that seems greatly attached to its breeding haunts, continuing, as I have repeatedly remarked, to visit certain fields long after the builder has taken possession of the immediate neighbourhood. The open fields between Kensal Rise and Willesden Green and certain spots in the vicinity of Park Royal and Ealing are cases in point. During migration the Tree Pipit occasionally visits the big parks within the city limits, and it still breeds at Dulwich, Wimbledon, Streatham, Norwood, and Croydon. Then, again, we can trace it as a regular summer visitor from Kew and Richmond northwards through Osterley, Hanwell, Southall, 'Twyford, Wembley, Harrow, and Kingsbury to Hendon, Highgate, Cricklewood, Hampstead, Elstree, Barnet, Enfield, Waltham, Epping, Romford, and many parts of Kent, especially in the vicinity of the Crays. So far as my own experience goes, the Tree Pipit scems commoner in the southern, western, and northern suburbs than in the eastern ones, but this may be due to a less thorough investigation.

The Tree Pipit appears in its summer haunts towards the end of April, quitting them again in September or October. There are many ideal haunts of this species in suburban London-spacious expanses of grass-land, well timbered, meadows on the borders of woods, and private parks. As its name implies, this species spends a good deal 


\section{THE BIRD-LIFE OF LONDON}

of time in trees, more especially during the nesting period, when the male loves to start its song-flights from some lofty perch in the branches, and from which he sings at intervals the livelong day. The female, however, keeps more closely to the ground, and it is there most of the food is obtained. The song of the Tree Pipit is both varied and musical, and always sounds best whilst uttered during flight. Ever and anon the bird starts fluttering upwards from some tree, warbling sweetly as he goes, upwards and upwards until the zenith of his flight is reached, when he sails down again with wings and tail outspread, uttering long-drawn notes of twee-twee-twee as he comes. Sometimes the song is finished on the tree, or even on the ground, sometimes as the bird flies from one tree to another. By the middle of July the song ceases, the moult comes on, and for the remainder of their stay the birds spend for the most part a terrestrial existence. The food of this Pipit consists of insects and larvæ, small worms, and tiny seeds. When the corn is in a soft, milky state the birds are fond of the grains. Upon the ground the Tree Pipit runs and walks very gracefully and nimbly. It breeds in May and June, making a cup-shaped nest amongst the meadow-grass or the herbage on a bank, often beneath a tree, of dry grass, roots, and moss, and lined with finer grass, and often hair. The five or six eggs vary considerably in colour, presenting several welldefined types, those in the same nest, however, being similar. They range in ground colour from white, with a greyish, bluish, or pinkish tinge, to pale olive, mottled, spotted, and blotched with reddish brown of various shades, purplish brown and olive-brown, and sometimes streaked with dark brown. The young keep in their parents' company for some time after leaving the nest.

The Tree Pipit has the general colour of the upper parts brown, with darker centres to each feather; the under I 28 
parts are sandy buff, spotted with dark brown on the throat, breast, and flanks; the wings are brown, the coverts tipped with dull white, forming a double bar; the tail is brown, the outer feathers white obliquely marked with brown. Bill brown, paler at the base of the lower mandible; tarsi and toes yellowish brown; irides dark brown. Length 6 inches. This Pipit can readily be distinguished from the other British species by its short, curved hind claw. The nestling is more profusely spotted on the under parts than the adult. 


\title{
THE MEADOW PIPIT
}

\author{
ANTHUS PRATENSIS
}

LOCAL names in surrounding counties: "Titlark" (Essex).

Status in British Avifauna: A common and widely distributed resident, subject to considerable local migration.

Radial Distribution within fifteen miles of $\mathrm{S}_{\mathrm{T}}$. Paul's: This species is commoner and much more widely distributed than the Tree Pipit. It may be met with during autumn and winter especially on almost any piece of fairly open ground from St. James's Park outwards. I have often seen it in partics in the Green Park, and it frequently visits Regent's Park, Primrose Hill, and other similar spots, and may frequently be noticed on railway banks, in allotments, and so forth. Meadow Pipits are sometimes very numerous on Wormwood Scrubbs, and the bird breeds in many localities in the immediate vicinity. It would be impossible to mention all the places in the more rural suburbs where this Pipit nests. Nothing nearly so fastidious in its choice of a haunt as the Tree Pipit, it may be found breeding in all suitable spots within the Metropolitan area, but perhaps nowhere within four or five miles from the centre of our radius. As previously remarked, the bird is more ubiquitous in autumn and winter, and then resorts to places where it is never found at other times of the year. This seems to be specially the case with respect to the Epping area.

The Meadow Pipit is more of a ground bird than the Tree Pipit, and it specially delights in land of a marshy or wet character. It is active enough on the ground, running and walking to and fro, but seldom resorts to trees or bushes. In the early spring the male resumes I 30 
his short yet pleasing song. This is usually uttered in the air, the bird at intervals rising from the ground in silence for fifty feet or more, then returning to the earth, singing as he comes, on outspread wings and tail. Except in the actual nesting season this Pipit is more or less sociable, or even gregarious, and even in summer numbers may be found breeding within a small area of suitable ground. After the young are reared parties and small flocks wander far and wide in quest of feeding-grounds, and in autumn especially these frequent many of the cabbageand turnip-fields in suburban London. Here they may be flushed from the growing crops, rising and taking short flights from one part of the cover to another, uttering a singularly plaintive peep as they do so. In severe weather they often resort to manure-heaps, farmsteads, and the exposed banks of any open water. Snowstorms are often fatal to them. With the advance of spring the parties break up and scatter over their breeding-places. The food of this Pipit consists of insects, small worms, snails, grubs, tiny seeds, and even occasionally grain. The breeding season commences in April, and the nest is always placed on the ground, sheltered by a small stone, a bush, a tuft of grass, or rushes, and frequently amongst heather, bilberry wires, or long herbage on a bank. It is loosely made, cup-shaped, of dry grass, moss, and bits of surrounding herbage, lined with fine grass and hair. The four, five, or six eggs are white suffused with brown, or pale green mottled, spotted, and speckled with brown of various shades.

The adult Meadow Pipit has the upper parts olivebrown, the feathers having darker centres, except on the rump and upper tail-coverts; the under parts are grcyish white, suffused with olive on the flanks; the neck, breast, and flanks streaked with blackish brown; some of the wing-coverts are marked with dull white, and the outer tail-feathers are also marked obliquely with white. Bill 


\section{THE BIRD-LIFE OF LONDON}

dark brown above, paler below; tarsi and toes pale brown, the hind claw being very elongated, longer than the toe; irides brown. Length 6 inches. The nestlings do not have the colours so bright, and the under parts are more spotted. 


\section{THE SKYLARK}

ALAUDA ARVENSIS

Local names in surrounding counties :

Status in British Avifauna: A common and widely distributed resident, its numbers enormously increased in autumn by migrants from Continental Europe.

Radial Distribution within fifteen miles of $\mathrm{S}$ t. Paul's: Remarkable as the fact may seem to be, the Skylark is one of London's most widely distributed and commonest birds. Harting records that a nest of this species was found on Primrose Hill. The occurrence was exceptional, perhaps, but there are not a few localities a mile or so outside that radius where this sweet-voiced bird habitually rears its young. During autumn and winter the Skylark visits many of London's open spaces which it shuns at other seasons. I have heard it singing on warm, open days in midwinter over Battersea Park, Clapham Common, Wormwood Scrubbs, and in various spots between Kensal Rise and Willesden Green. Its breeding-zone may be said to commence with the more rural suburbs, say from the six-mile radius outwards, becoming more thickly populated as we reach the open country, and more especially the higher-lying districts. It is more abundant in the Metropolitan area in winter than in summer, then becoming to a great extent gregarious. Flocks frequent many of the fields, marketgardens, and allotments wherever suitable food can be obtained. It still breeds sparingly within a mile of Kensal Rise, in many places in the Willesden district, and this very summer (1908) I heard it repeatedly in song above the grounds of the Franco-British Exhibition at Shepherd's Bush. Nany of these birds frequent the fields adjoining Wormwood Scrubbs, and breed in them. Similar remarks apply to many other suburban districts. 


\section{THE BIRD-LIFE OF LONDON}

The "Sky" Lark, notwithstanding its trivial name, spends most of its time upon the ground, where it is very active, both running and walking, although it never seems to hop. It loves to frequent the bare, open fields, haymeadows, growing grain until the ears have burst, stubbles, and weedy pastures. During the autumn and winter it chiefly lives in flocks, and at these seasons it is exceptional for the males to indulge in soaring flights or in song. The Skylark resumes his song with the very first days of spring, and continues in voice from then onwards to the moulting season. The loud, glad carol of this bird needs no description here. It is one of the most familiar sounds of the countryside, filling the sky often when the tiny brown singer is almost lost in the spacious heights above. During the mating season the male often soars for a little way above the female, singing loudly; and sometimes he may be observed to warble whilst standing on some clod of earth, or even running along the ground. The food of this Lark consists of worms, grubs, small seeds, and grain, with an occasional insect. 'The Skylark is an early breeder, eggs for the first brood being laid in April, for the second as late even as July. The nest is always made upon the ground, and the favourite situation in the London area is amongst the meadow-grass or growing crops, but occasionally in the coarser vegetation and heather of the commons. It is placed in a shallow depression, and made outwardly of dry grass, twitch, and bits of moss, and lined with finer grass, roots, and horsehair. The four or five eggs are greyish white, or olivewhite mottled and freckled with olive-brown and grey. Like all ground-building birds, the hen is a close sitter, and usually remains brooding on the nest until almost under the feet of the passer-by. In autumn the various broods unite into flocks for the winter.

The adult Skylark is brown above, the feathers having darker centree; the under parts are buffish white, most 


\section{THE SKYLARK}

pronounced on the chest and flanks, which are spotted and marked with dusky brown; the outer tail-feather is white, except on the outer web, and the next is marked with white on the outer web. Bill dark brown, paler below; tarsi and toes yellowish brown; irides brown. Length 7 inches. The nestling is spotted above with black and buff, and the under surface is much more profusely spotted than in the adult. 


\section{THE WOOD LARK}

\section{ALAUDA ARBOREA}

Local names in surrounding counties:

Status in British Avifauna: A local resident in England, especially in the southern and midland counties; very rare in Scotland, and exceptionally local in Ireland.

Radial Distribution within fifteen miles of $\mathrm{S}_{\mathrm{T}}$. Paul's: There is much evidence to suggest that the Wood Lark was a by no means rare bird within the Metropolitan area years ago. Unfortunately the bird-catcher and the builder have both done their best to exterminate it, and it is doubtful if there are any localities at all close to London which the Wood Lark frequents. It is sometimes met with at Wimbledon, and was found breeding at Kingston upwards of twenty years ago. It formerly frequented the Epping area, but seems to be extinct or nearly so there now, thanks entirely, very likely, to the persecution of bird-catchers. There are many likely haunts for the Wood Lark in Surrey within our limits, and where the dry, sandy soil which the species seems everywhere to desire is eminently suited to it, but I know of no place where the bird is at all common. It is excessively local nowadays everywhere in the Metropolitan area, but is of more frequent occurrence during autumn and winter, when the species is more addicted to wandering from its usual haunts.

The habits of a species so rare within our limits require but little detailed notice in the present volume. There is much in the ways of the Wood Lark (which may be readily recognised in the air by its short tail) resembling the habits of the Tree Pipit. The Wood Lark is by no means a bird of the open fields, but loves to resort to spots where trees are abundant, the well-timbered parks and pastures, the borders of woods and plantations. I 36 


\section{THE WOOD LARK}

During the breeding season, which continues from March to June, the male may constantly be seen about the trees, from which he starts to sing whilst soaring in the air or passing from one tree to another. Less frequently the song is uttered on the ground. The voice of the Wood Lark by some is considered to be even better than that of the Skylark, and if greater continuance and richness of tone are taken as points in its favour their judgment cannot be questioned. 'The usual call-note is a liquid double cry, very similar to that of the Skylark. It subsists upon much the same food. The nest is placed upon the ground, usually well concealed under a tuft of grass or a small bush, and is made externally of dry grass and moss, lined with finer grass and a little horsehair. The four or five eggs are white tinged with buff or olive in ground colour, spotted and freckled with reddish brown and grey. After the breeding season the male, like his mate, becomes more terrestrial, and the broods often keep together during the winter. Odd Wood Larks may sometimes be met with in flocks of Skylarks.

'The adult Wood Lark is brown above, the feathers with dark centres, except on the rump and upper tail-coverts; the wing-coverts are tipped with white, and the pale buff eye-stripe is conspicuous; the tail-feathers are brownish. black, marked with white at the end, the outer ones paler, with a darker mark on the inner web. The under parts are white, suffused with buff on the breast and abdomen and with brown on the flanks; the throat, neck, breast, and flanks are spotted with blackish brown. Bill dark brown, paler below; tarsi and toes pale brown; irides brown. Length $5^{\frac{1}{2}}$ inches. 'The nestling is spotted above with black and buff, and the nearly yellow under surface is more profusely marked than in the adult. 


\section{THE COMMON BUNTING}

\section{EMBERIZA MILIARIA}

Local names in surrounding counties: "Bunting Lark" (Essex).

Status in British Avifauna : A widely but somewhat locally distributed resident, rarer in the north.

Radial Distribution within fifteen miles of $\mathrm{S}_{\text {t. }}$ Paul's: The Common Bunting by no means deserves its name anywhere within the Metropolitan area. It must be classed as one of our most local London birds, and one that in a good many districts has become rarer of late years, doubtless owing to the fact that so much open ground has been built on, enclosed, or devoted to public uses. I can record this species from the Wembley and Horsenden districts, from Wimbledon and Richmond, from Croydon, Epsom, the Crays, and Epping, in all of which it possibly nests sparingly. It has been recorded as a nesting species from Mitcham and Surbiton. To the inner portions of our area the Common Bunting must be a very irregular visitor. I have no records from the urban parks, but these localities, of course, present few if any attractions to such an open-country bird. This Bunting becomes much commoner beyond our western limits in Bucks and Berks, from which counties flocks are recorded, especially in autumn.

We have here another species upon whose habits we need not dwell at any great length. The Common or Corn Bunting cannot easily be overlooked if it is present in any locality, because the song of the male is very characteristic and persistent, and the birds are fond of exhibiting themselves on the tops of tall weeds, bushes, and on telegraph wires. The song is a poor one. One or two long-drawn notes seem to be full of promise, but these invariably end in a hurried splutter, and all is over. This 138 


\section{THE COMMON BUNTING}

is repeated over and over again with irritating monotony as the bird sits on some exposed spot, or even whilst he is fluttering lazily with legs hanging down from one perch to another. The call-note is long-drawn and harsh. The food of this species consists chiefly of grain and seeds in winter, but in summer large quantities of insects and larvæ are sought. Like most of its kind it is social and gregarious during the non-breeding season, and then is often seen on stubbles and in the vicinity of stacks and farm-buildings. The Corn Bunting breeds in May and June, making a slovenly nest upon the ground, usually amongst grass and growing crops. It is formed of dry grass, moss, roots, twitch, and dead leaves, lined with similar but finer material and horsehair. The five or six eggs are white, tinged with grey, buff, or purple, spotted, blotched, and streaked in profusion with various shades of brown and violet-grey. The scribbled lines and scratches on the eggs often lend them a very handsome appearance.

'The adult Common Bunting has the upper parts brown, marked with darker brown; the wing-coverts and inner secondaries have pale brown margins; the wings and tail are dark brown, with similar pale margins; the under parts are dirty white, with triangular spots of dark brown on the sides of the neck and the breast, and with streaks of the same on the flanks. Bill dark brown, paler below; tarsi and toes pale brown; irides brown. Length $7 \frac{\text { I }}{2}$ inches. The nestling is more rufous in general colour, and is more profusely spotted on the under surface. 


\section{THE YELLOW BUNTING}

\section{EMBERIZA CITRINELLA}

Local names in surrounding counties : "Writing Lark" (Essex, Surrey).

Status in British Avifauna: A common and widely distributed resident, its numbers perceptibly increased in autumn.

Radial Distribution within fifteen miles of $\mathrm{S}$. Paul's : The Yellow Bunting cannot be classed with those many species that are more or less familiar in the central portions of the Metropolitan area. We must take practically the seven-mile radius before we can reasonably expect to meet with this bird in even tolerable numbers, and then it is certainly a local species, becoming increasingly frequent as the outer ring of suburban London is reached. Between the seven- and nine-mile radius I can record the Yellow Bunting from the Wimbledon and Richmond districts, from Twyford, Park Royal, and Wembley, from Kingsbury, from Hendon, Barnet, and Enfield, from Epping, Wanstead, Blackheath, Bromley, and Morden. Beyond these limits it becomes scarcely necessary to specify the districts, for the Yellow Bunting becomes more and more widely distributed and general in its occurrence. In winter this Bunting occasionally mixes with flocks of House Sparrows about hay- and cornricks, and I have often met with it in the hedges by the wayside about Streatham and Dulwich. On the whole it seems to be scarcer in the immediate southern suburbs than the others.

Showy plumage and a habit of perching conspicuously on the tops of hedges and bushes render the Yellow Bunting little likely to be overlooked. The song of the male is one of the first to greet the ear in spring, and his voice, commencing in February, is one of the most I 40 

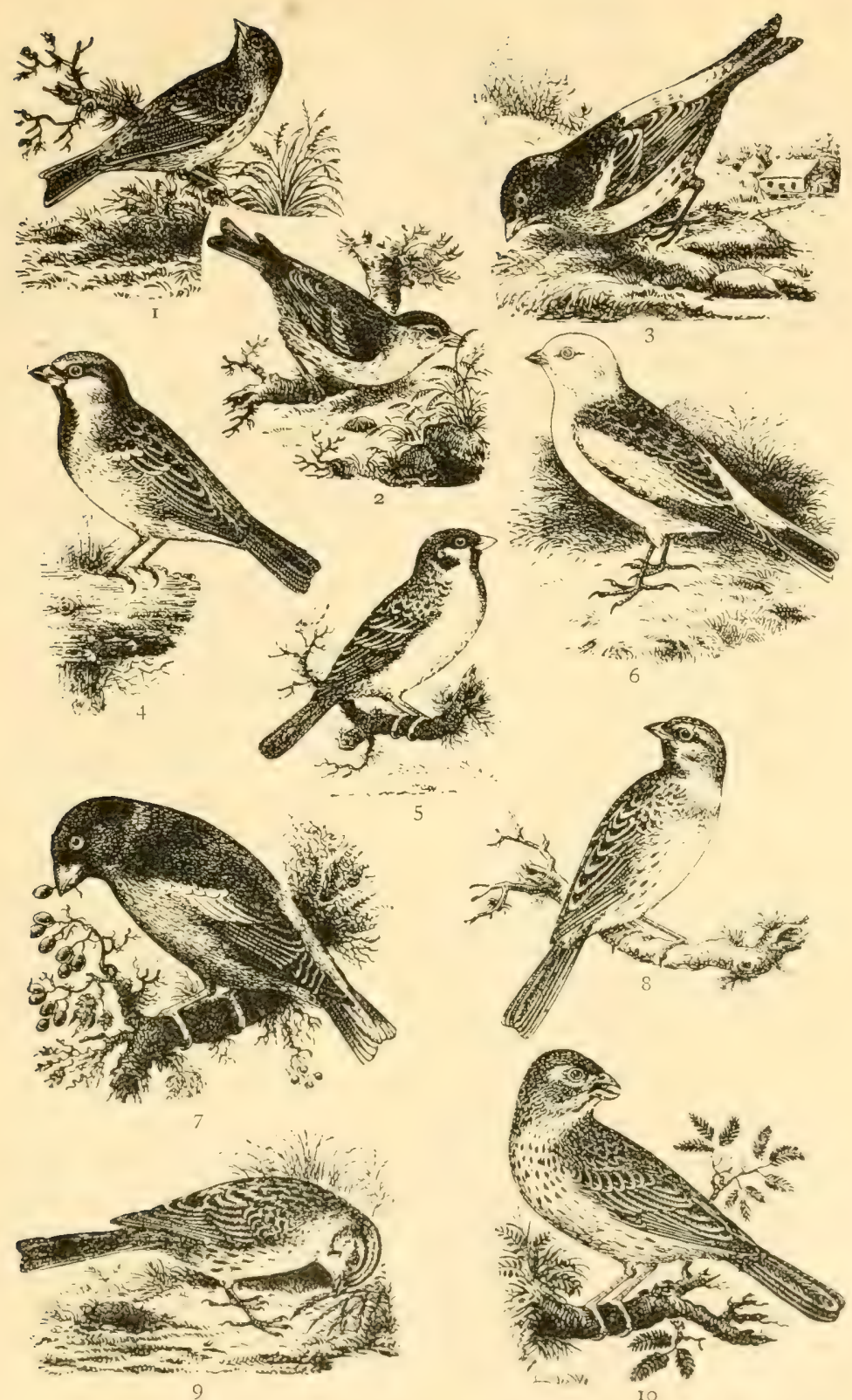

r. Twite. 2, Siskin. 3. Brambling. 4. House Sparrow. 5. Tree Sparrow.

6. Snow Bunting. 7. Hawfinch. 8. Cirl Bunting. 9. Yellow Bunting. Io. Corn Bunting. 



\section{THE YELLOW BUNTING}

persistent. It consists of a series of monotonous notes on an ascending scale, concluding with a harsh, prolonged double one, which country-folk say resemble the sentence "A little bit of bread and no cheese." The call-note of this Bunting is a harsh cburrze, sometimes prolonged into several notes. The song continues well into the autumn. Like the preceding species, its food consists chiefly of seeds and grain in winter, of insects and larvæ in summer, and on these its young are mostly reared. In autumn the Yellow Bunting becomes more or less gregarious, and flocks during hard weather often resort to ricks and farmyards. They often consort with Sparrows and other hard-billed birds. As this Bunting rears several broods during the season its nest may be found at any time between April and August. Its favourite nesting-places are in fields and lanes, by the hedgerows, on gorse- and bramble-covered ground. The nest is usually made amongst the herbage on a bank, but sometimes a low bush or thicket is selected. It is made of dry grass, roots, withered stalks, and bits of moss, lined with finer grass and roots and horsehair. The four or five eggs are greyish or purplish white, spotted, streaked, and lined with dark liver-brown, paler brown, and grey. It is the peculiar scratchy character of these markings, so characteristic of the eggs of Buntings, that has led to the bird's local name of "Writing Lark," which, I may add, is by no means peculiar to Essex or Surrey, but is widely prevalent in many other counties.

The adult male Yellow Bunting has the crown lemonyellow, sparingly streaked with brown, a yellow eycstripe, the rest of the upper parts chestnut, streaked with blackish brown on the back and scapulars; the wings are dark brown margined with yellow, the tail dark brown, the central feathers with reddish brown margins, the rest narrow yellow ones, and the two outermost with a patch of white on the inner web. The under parts are yellow, 


\section{THE BIRD-LIFE OF LONDON}

shading into olive on the breast, streaked on the cheeks, breast and flanks with reddish brown, the latter suffused with chestnut-brown. Bill brown, palcr below; tarsi and toes pale brown; irides brown. Length 7 inches. The female is duller in colour than the male, has little or no trace of yellow on the head, and the under parts are more streaked. The nestling closely resembles the female in general coloration. 


\title{
THE CIRL BUNTING
}

\author{
EMBERIZA CIRLUS
}

Local names in surrounding counties:

Status in Britisin Avifauna: A sparingly distributed and local resident in the southern and midland counties of England and in Wales.

Radial Distribution within fifteen miles of $\mathrm{S}$ t. PAul's: Although the Cirl Bunting has been known to breed within the nine-mile limit, it must be classed as one of the rarest and most local of London birds. I have no records of the species in the inner districts, from none of the urban parks, and so forth, although the evidence, of course, is only negative. That it may occasionally wander to such places is by no means impossible, looking to the fact of its suburban distribution. Perhaps other observers may have been more fortunate. The Cirl Bunting has been reported nesting at Wimbledon and the adjoining district of Coombe Wood, also near Wembley Park, which is a very suitable locality for the species. In Essex there are at present, I believe, no nesting records, and the bird is certainly a rare one in the east. In the more remote portions of the Metropolitan area I may mention Croydon and Epsom as localities for this species, which seems to prefer fairly well-timbered country, tall hedgerows, and fields with plenty of trees in them. It can nowhere be regarded as a plentiful species.

The Cirl Bunting was first discovered to be a British bird in Devonshire, by Montagu, more than a hundred years ago. I have seen a good deal of this species in its Devonshire haunts, where it is quite common, and my observations lead me to describe it as a Tree Bunting. It is by far the most arboreal of the indigenous British Buntings, and possibly this peculiarity causes it to be much overlooked. A bird that spends so much of its 


\section{THE BIRD-LIFE OF LONDON}

time in tall trees may easily escape notice. The song of this Bunting commences in March, and continues well into the autumn. It closely resembles that of the Yellow Bunting in its opening stage, but ends even more abruptly, the final long-drawn note being omitted. One may aptly compare it to that of a Yellow Bunting suddenly interrupted. Apart from its habit of frequenting trees, the Cirl Bunting very closely resembles the commoner species in its economy. It feeds on similar objects, is more or less gregarious in winter, consorts with Sparrows and other Finches, has the same dipping flight, similar call-notes, and nests in much the same situations. Preparations for the first brood commence in late April, and the breeding season continues until July. The nest is perhaps more frequently placed in a low bush-a gorse for preference-than upon the ground amongst herbage. It is made externally of dry grass, roots, dead leaves, moss, and twitch, and lined with finer roots and horsehair. The four or five eggs are bluish white in ground colour, blotched and streaked, and pencilled in the true Bunting style with intensely dark brown, paler brown, and grey.

In the colour of the upper parts the Cirl Bunting very closely resembles the Yellow Bunting, but the yellow crown is wanting, the head, rump, and upper tail-coverts being olive-green, streaked with black on the former and dusky brown on the two latter. A yellow streak reaches over the eye; another similar in colour extends below it. The wings and tail resemble those of the preceding species, but the smaller wing-coverts are olive instead of rich brown. The throat is black, followed by a broad patch of yellow ; across the breast is an olive-green band, merging into chestnut; the remainder of the under surface is yellow, with a darker shade on the flanks, which are streaked with brown. Bill brown, paler below; tarsi and toes pale brown; irides brown. Length about 7 inches. The female

\section{44}




\section{THE CIRL BUNTING}

is much more dingy in general coloration, and wants the black and yellow markings on the head, and may readily be distinguished from the female Yellow Bunting, which she much resembles, by the olive rump and upper tailcoverts. 'The nestling resembles the female, but is even more dull in coloration. The Cirl Bunting may, in any plumage, always be recognised by the olive-green rump and wing and upper tail-coverts. 


\section{THE REED BUNTING}

\section{EMBERIZA SCHENICLUS}

Local names in surrounding counties: "Reed Bunting," "Black-headed Bunting" (Essex).

Status in British Avifauna: A widely if somewhat locally distributed resident, subject to considerable internal migration.

Radial Distribution within fifteen miles of $\mathrm{S}_{\text {t. }}$ PAUL'S: There are few if any quite suitable localities for the Reed Bunting within the most central portions of the Metropolitan area. It is a riverside species, but the banks of the waters must offer suitable cover and food to tempt it to sojourn upon them. Otherwise in the more rural districts the bird is by no means a scarce one, and I find it recorded from all or most of them. As the Thames begins to assume a country aspect we may expect to meet with the Reed Bunting, say, from Richmond onwards. It also frequents the banks of the Mole, the Wandle, the Beverley, the Lea, and many other less important streams, besides the banks of canals, ponds, and even ditches and marshy places. During autumn and winter its aquatic tastes are nothing like so strongly developed, and then it roams about a good deal in company with other seed-eating birds, frequenting hedges, stack-yards, and fields, especially stubble. It is possible that this Bunting may then approach the city within the four- or five-mile radius, but I have no records from any of the urban parks. It is a species of the outer suburbs, becoming commoner and more widely dispersed at all seasons as we get out into the comparatively open areas.

The marked contrast in the black and white of its plumage, especially during flight, renders the Reed Bunting one of the most conspicuous and easily identified of the smaller birds by the waterside. During spring I 46 


\section{THE REED BUNTING}

and summer especially, when this Bunting lives in pairs, each seems to annex for its own particular use some special length of the stream, and here the birds may be seen flitting in a dipping course from one bush to another, or clinging to some tall rush or bending reed stem, then returning by a détour across the water to their favoured haunt. They are wary enough, but not exactly shy, and show little inclination to conceal themselves. At intervals the male indulges in a monotonous and unmusical sort of song, typically Bunting-like in character, and from time to time one bird calls to the other in a harsh seeze. The food of this Bunting consists of seeds and grain, insects and larvæ, the latter especially of an aquatic nature. During the non-breeding season much of this food is sought upon stubbles and reed-grown pastures, ricks, and in farmyards. It shows some social tendencies, and often consorts with other grain and seed-eating birds. The breeding season of the Reed Bunting begins in April, and continues until June, or even July, two broods being reared. The nest is usually made upon or close to the ground, often sheltered by a tuft of rushes, or amongst the rank vegetation on the banks of the water. It is made of dry grass and other scraps of dead vegetation, and lined with fine grass, hair, and the flowers of the reeds. The five or six eggs range from pale olive to buff in ground colour, streaked and spotted with rich brown, paler brown, and grey.

The adult male Reed Bunting is a very pretty little bird, having the head and throat coal-black, with a white collar and cheeks; the rest of the upper parts is chestnut, shading into grey on the rump and upper tail-coverts, each feather having a rusty black centre; the wings are dark brown, with chestnut margins; the tail is similar in colour, but the two centre feathers are like the back, and the two outermost on each side are marked with white on the outer webs. The under parts are white, 


\section{THE BIRD-LIFE OF LONDON}

shaded with pearl-grey on the breast and streaked with pale brown on the flanks. Bill black, paler below; tarsi and toes brown; irides brown. Length 6 inches. The female lacks the black head and throat, the former being brown, each feather with a paler margin. The eye-stripe is pale buff; the throat is dirty white, and the breast and flanks are streaked with brown. The nestling resembles the female in colour. After the autumn moult much of the conspicuous beauty of the male is concealed by the margin of pale brown that fringes all the black feathers. 


\section{THE SNOW BUNTING}

\section{EMBERIZA NIVALIS}

Local names in surrounding counties:

Status in British Avifauna: A resident, and breeds very sparingly in Scotland, but chiefly known as a local winter visitor to littoral and low-lying districts.

Radial Distribution within fifteen miles of $\mathrm{S}_{\mathrm{T}}$. PAUL'S: To include the present species in an account of the birds of London seems to be rather an anomaly, and I only do so because it is undoubtedly a rare visitor to the Netropolitan area, but one that is probably frequently overlooked. The Snow Bunting has been shot so often within our radius that a record of its occurrences is not necessary here. I have no information relating to its appearance in any of the more urban districts, but on one solitary occasion I saw a single example on the extreme western side of Wormwood Scrubbs. This was five years ago. I believe the bird has been frequently shot at Epping, and the extreme eastern suburbs are the most likely to be favoured by its nomadic and uncertain visits.

The Snow Bunting is very erratic in its movements, appearing at irregular intervals and in varying numbers. From October onwards to the following early spring this bird, if it comes at all, may be expected in the London area. Odd birds frequently attach themselves to flocks of other Buntings and Finches at this season, and I have seen individuals massed with Skylarks. In the breeding season-June and July - the male has a pleasing musical song, uttered both when at rest or fluttering in the air ; the notes are a shrill whit, and the usual long-drawn, Bunting-like peez $b$. The former only is heard in England, as a rule. The food of this species consists of seeds, grain, small fruits, insects, and larvæ. It spends a good deal of time upon the ground, running and hopping about 


\section{THE BIRD-LIFE OF LONDON}

in quest of food, but does not refrain from perching in trees, as some writers have suggested. The nest is made in a crevice of rocks, and well concealed. It is more compactly made than that of most Buntings, formed externally of dry grass, roots, and scraps of moss, and lined with finer roots, hair, wool, and feathers. The five or six eggs, sometimes one or two more, are greyish white or very pale blue in ground colour, spotted and blotched-less frequently pencilled-with reddish brown. But one brood is reared in the year.

In breeding plumage the adult male Snow Bunting is mostly black and white; but in autumn and winter, when it visits us, most of this is concealed by the long fringes of rufous brown that gradually wear away before the summer. Then the head, the wing-coverts, the bases of the primaries, the outer tail-feathers, and the whole of the under parts are white, the remaining plumage black. Bill black; tarsi and toes black; irides brown. Length 7 inches. The female is not so brilliant in coloration, and is more mottled with brown, even in summer. The nestling has all the smaller feathers greyish brown, with dark centres, except the under tail-coverts and abdomen. 


\title{
THE CHAFFINCH
}

\author{
FRINGILLA CALEBS
}

Local names in surrounding counties: "Karfinch" (Kent).

Status in British Avifauna: A common resident in all suitable districts, its numbers increased in autumn by migrants.

Radial Distribution within fifteen miles of St. PAUL's: The Chaffinch is another well-known and widely distributed species within the Metropolitan area. It breeds more or less regularly as near to the central districts as Regent's Park (certainly in the Botanical Gardens, and probably in the Zoological Gardens) and Battersea Park, but closer in it can only be classed as an irregular winter visitor. As the suburbs become more rural the Chaffinch, of course, becomes increasingly common. It is a common bird in the Streatham, Wimbledon, Richmond, and Bushey districts, and thence passing northwards it is of general occurrence about Hounslow, Kew, Chiswick, Gunnersbury, Ealing, Osterley, Hanwell, Twyford, Wembley, Harlesden, Cricklewood, Willesden, Kilburn, Hampstead, Highgate, Wanstead, southwards to Greenwich, Brockley, Dulwich, and Norwood. Throughout the radius of the more outlying suburbs the Chaffinch is, if anything, still more numerous and generally dispersed. In winter its numbers seem to be perceptibly increased in some districts by migrants, and at this season it visits various parts of the more central area. I have seen this species in winter as close to St. Paul's as Lincoln's Inn, and very probably it occasionally visits many of the larger squares. I can also record it then from St. James's Park, the Green Park, Hyde Park, Buckingham Palace grounds, Holland Park, Peckham Ryc, Clapham Common, and 


\section{THE BIRD-LIFE OF LONDON}

near to Kennington Park. Doubtless other observers can add very extensively to this list.

The Chaffinch is entitled to be included in the special list of London's commonest birds. Its cheery call-note and bright and spirited song give life and animation to many a suburban spot otherwise songless and almost void of bird-life. In suburban London there are many gardens, shrubberies, pleasure-grounds, and so forth that offer this sprightly bird a safe asylum, and here from February onwards to the summer the short, emphatic song of the Chaffinch may be heard, even in the busy streets near by, in the lulls of traffic noise. The wellknown call of pink-pink is often heard during autumn and winter in places where the bird never stays to nest, but its transient visits are none the less welcome for that. The food of this species is composed of small seeds, grain, and, in summer especially, insects and larvæ, the young being practically reared on the latter fare. In early spring the flocks that have been massed since the previous autumn break up into pairs, and the resumption of song by the male heralds the breeding season. At this time. too, the sharply uttered $u$-whit of the male is heard very frequently. The nests for the first broods are commenced in April, for later ones in June or July. For neatness and beauty the dainty, cup-like nest of the Chaffinch is almost without an equal. It is placed in some triangular fork of the branches of a fruit or other tree, or less frequently in a bush or hedgerow, sometimes supported on a thin branch close to the trunk of a big tree, to which it is also partially attached. The outer materials of moss, dry grass, roots, lichens, and wool are all finely felted together with cobwebs, cocoons, and vegetable down, and finally lined with hair, feathers, wool, and down. The outside is made to resemble the surroundings as closely as possible, so that nests vary a good deal in appearance. One was found in Hyde Park built to a I 52 


\section{THE CHAFFINCH}

great extent of discarded wax vestas and bits of thread and silk, the sides garnished with paper from cigaretteends. Nearly a fortnight is occupied in its construction. The five or six eggs are pale bluish green in ground colour, spotted, speckled, and occasionally streaked with dark purplish brown, suffused with paler brown, many of the dark round spots being surrounded by paler washes. The parents become very noisy and demonstrative when disturbed at the nest. After the breeding season Chaffinches flock, and often associate with Greenfinches, Sparrows, and other seed-eating species, then frequenting stubbles, ricks, farmyards, and even the roads.

The male Chaffinch is a very handsome bird, some of the upper parts being slate-grey, merging into black on the forehead, chestnut on the mantle, and green on the rump; the wings are dark brown margined with yellow, the coverts black and white, showing out very boldly as a bar during flight; the tail is brownish black, the central feathers grey, the two outermost having a wedge-shaped mark of white. The under parts are pale chestnut, with a pronounced pinkish flush on the breast and abdomen, and shading into white on the vent and under tail-coverts. Bill black; tarsi and toes black; irides brown. Length 7 inches. The female has the same patterns of colour as the male, but her plumage is not so brilliant, and the head is nearly uniform with the back; the under surface is rufous brown, and shows no vinaceous tint. In the nestling the wings and tail are similar to those of the adult, but the small body-feathers are greyish brown, with obscure dark centres, except to those on the abdomen and under tail-coverts. 


\section{THE BRAMBLING}

FRINGILLA MONTIFRINGILLA

Local names in surrounding counties: "Bramble-Finch" (Essex).

Status in British Avifauna: A somewhat local and capricious winter visitor, yet a common and widely distributed one.

Radial Distribution within fifteen miles of St. Paul's: The Brambling is by no means an uncommon visitor to the Metropolitan area up to (and possibly nearer to the central districts) the four-mile radius. I have records of it from Battersea Park, Kensington Gardens, Regent's Park, Clapham, Dulwich, and Peckham. North of London it is an irregular visitor to Hampstead, and has been observed at Highgate. In the more outlying districts its appearance, of course, becomes less noteworthy. I have met with this species in the Willesden, Wembley, and Twyford districts, about Ealing, Hanwell, and Osterley. It is also of tolerable frequency, but not every winter, in the Hounslow, Bushey, Richmond, Wimbledon, and Streatham areas. To these localities I have evidence of its occurrence to add from Merton, Mitcham, Croydon, Sydenham, Bromley, the Crays, Wanstead, and Epping. It is just as capricious and irregular in its appearance round London as elsewhere, and in some winters scarcely an example will be reported from districts where in other years it had been numerous. Although outside our limits, I may add that Burnham Beeches is a favourite resort of this Finch. In some parts of Kent also, within easy reach of London-Groombridge, for instance-it frequently occurs in large numbers.

During its sojourn in our country the Brambling lives chiefly in flocks of varying size, which take up their quarters in suitable spots, and usually remain in their I 54 


\section{THE BRAMBLING}

vicinity throughout the winter. These flocks make their appearance in November, and remain for about four months. They particularly affect beech-woods where mast is plentiful, and upon which they largely subsist as long as the supply continues. I have noticed that Bramblings return each year to certain spots, which may be regarded as winter rendezvous, and where they roost, spreading over the neighbouring country during the daytime to feed. Their favourite roosting-places are shrubberies or woods where evergreens are common. From these centres flocks frequently visit the stubbles and fields that are being manured, for the Brambling seems always to prefer an animal diet far more than its ally the Chaffinch does at this season. Of course the bird is songless during its stay with us, but at its breedinggrounds indulges in a low, musical, warbling performance. In winter the flocks twitter incessantly as they rest on the trees, especially towards nightfall. The food of this species consists of grain, mast, insects and larvæ, and small worms, manure-heaps being visited for the latter during hard weather. Its nearest breeding-places are in Scandinavia. The nest is usually made in a fir- or a larchtree, from fifteen to twenty feet from the ground, and is nothing nearly so neat as that of the Chaffinch. It is made of moss, lichens, strips of bark, mixed with cobwebs and vegetable down, and lined with fine dry grass, down, and feathers. The half-dozen eggs closely resemble those of the Chaffinch, but are greener in ground colour, and the markings are not so prominent, and more washy in appearance. After the nesting season the habits of this Finch are very similar to those of the Chaffinch.

The adult male Brambling in summer has the upper parts, including the head, blue-black, but the centre of the rump is white; the smaller wing-coverts are pale chestnut, the median ones white, the greater ones tipped with white, which, with the white bases to the inner 


\section{THE BIRD-LIFE OF LONDON}

primaries, forms a conspicuous wing-bar. The under parts are pale chestnut, shading into white on the abdomen, and the flanks are spotted with black. Bill black; tarsi and toes rufous brown; irides brown. Length about $6 \frac{\mathrm{I}}{4}$ inches. The female is duller and browner than the male in colour. The nestling closely resembles the adult in general colour. In autumn the bird is very different in appearance, owing to the pale chestnut fringes that conceal most of the black plumage, and the white parts are suffused with buff, while the margins to the quillfeathers are broader and yellower. The bill also is yellow at this season, and during the winter. 


\section{THE HOUSE SPARROW}

PASSER DOMESTICUS

Local names in surrounding counties :

Status in British Avifauna: A common and widely distributed resident, but scarce and local in uncultivated districts.

Radial Distribution within fifteen miles of St. Paul's: The House Sparrow enjoys the unique position of being the commonest and by far the most abundant of London's birds. From the great cathedral, which we have taken as the centre of our radius, and on which the House Sparrow congregates and breeds in abundance, to the outermost and most rural of the suburbs of the Metropolis - a vast area thirty miles across-this species abounds. There is scarcely a street, however mean or grimy or crowded, there is scarcely a building, however humble or palatial, that does not afford it a refuge or upon which it may not be seen. It stuffs its untidy nests in to the crevices of every kind of building, or amongst the carvings of statuary, the effigies of royalty being shown no more respect than the stone or plaster equivalents of less exalted personages. London may be described as a huge colony of House Sparrows, possibly numbering millions, and in certain spots, such as in the grain docks, in some of the public parks-Hyde Park, for instance-and at the Zoological Gardens, their numbers are literally enormous. There is a perceptible exodus in summer to the outlying districts, where grain-fields are an attraction, but otherwise the Sparrow is ever in evidence.

Changed conditions of life have produced many noteworthy characteristics in the House Sparrow during, say, the past five hundred years or more. Not the least interesting of these is its gregarious habits. It is the only British Finch that lives in colnnies throughout the year. 


\section{THE BIRD-LIFE OF LONDON}

All others separate into pairs for the breeding season. In London the Sparrow breeds almost all the year through, or at all events endeavours to do so. To a large extent the artificial economy of the House Sparrow may be studied from almost every window in the Metropolis; there is not an open space where its actions may not be observed during all the hours of daylight. Fearlessly it searches for food in the busiest thoroughfares, its meals interrupted a thousand times a day by the ceaseless traffic, its life in jeopardy at almost every moment. The nature of its food must also have changed to an amazing extent, so much so that the bird can now, and does, subsist upon almost everything eatable. Its cheery chirp remains the same in town and country alike; but its social tendencies seem to have increased. For instance, the gathering of these birds towards evening in a certain tree, especially in autumn, where they keep up a twittering babel until darkness disperses them to their roostingplaces, seems to be peculiar to London. It speaks well for the Sparrow's fertility and adaptability to so many varied conditions of life as the vast Metropolis presents that it should be able to maintain its numbers. Enemies and fatal contingencies surround it. Not the least serious of these are cats and rats, and in one or two places owls. Almost any day in summer on the banks of the outlet to the Serpentine in Hyde Park you may stand and watch the rats prey upon the young Sparrows that are attracted by the crumbs thrown to them by the park loungers. I have here seen half a dozen young Sparrows seized and carried off by rats, scarcely an arm's-length away from where I was standing, in the course of half an hour. The rats come out of the beds of plants and seize the unsuspecting birds in the most impudent manner. London's cats are also great destroyers of this bird, as they are of many other more interesting species, especially in the parks, and I for one should like to see them banished I 58 


\section{THE HOUSE SPARROW}

for ever from such places. Bird-life then would be in comparative peace, and the number of species frequenting these places considerably increased. During summer the London Sparrow does an incalculable amount of good in ridding vegetation of injurious insects, especially aphides, and upon these its young are chiefly reared. The House Sparrow, as previously stated, breeds at least during nine months of the year. Its nest is made almost everywhere, and is of several types - domed when in trees and bushes or amongst statuary, cup-shaped when in holes of trees or buildings. The materials are of infinite variety. The four or five eggs vary a good deal in colour, but the ground is white, with a more or less grey or brown tinge, marked to a varying extent with different shades of brown and grey.

Except in autumn, just after the moult, the London Sparrow is so grimy and disreputable that one can scarcely gain a correct idea of his actual coloration. He needs but the briefest description here. The adult male has a dark grey crown, encircled by chestnut, the upper back chestnut streaked with black, the lower back and rump ash-brown; the feathers under the eye are black, a spot behind the eye white, the ear-coverts and cheeks dirty white; the wings and tail are brown, the former with a white bar; the throat and fore-neck are black, the remainder of the under surface greyish white, suffused with brown on the flanks and under tail-coverts. Bill black; tarsi and toes brown; irides brown. Length 6 inches. The female is not so showy as the male, wants the black throat, the grey and chestnut on the head, the white wing-bar and cheeks. The nestling resembles the female, but is a little paler. 


\title{
THE TREE SPARROW
}

\author{
PASSER MONTANUS
}

LOCAL names in surrounding counties:

Status in British Avifauna: A comparatively rare and local resident, although widely and irregularly dispersed, its numbers increased in autumn by migrants, which visit areas in winter where the species is seldom or never known to breed.

Radial Distribution within fifteen miles of $\mathrm{S}_{\text {t. }}$ PAUL's: It is a rather remarkable fact that the Tree Sparrow in England shows an antipathy to towns, whilst on the Continent in many places it is quite as familiar in them as the House Sparrow. I am unable to say whether the Tree Sparrow ever visits the central parts of the Metropolitan area; I have never observed it in the urban parks or in any of the open spaces, although I am always on the watch for it. That it draws nearer to the city limits during winter seems certain; it has been recorded from Tooting at that season, and I have met with it then in the Wembley and Kingsbury districts. It breeds and is a resident in the Epping area, but is excessively local. I know of no breeding-places in Middlesex, but in Surrey it certainly nests in the Richmond district, and has also been found doing so at Wimbledon. The species is probably confused a good deal with the House Sparrow, and its distribution within the London limits requires careful investigation. The available evidence all tends to show that the bird is very local, and that it is most frequently detected near London during winter.

Due allowance being made for difference of haunt and conditions of existence, the habits of the Tree Sparrow closely resemble those of the preceding species. It may readily be distinguished from its commoner ally by its uniform chestnut head and black ear-coverts, and as the 160 
sexes are alike in colour the identification is made all the more easily. The Tree Sparrow, especially in winter, is often found in company with the House Sparrow, notably when hard weather brings it near to houses. Its ordinary call-note is a trifle shriller, and during the breeding season its voice is more musical, although it cannot be called a song. At all times it is shyer and warier than its congener. Its food consists of seeds and grain, insects and larvæ, and on the latter its young are reared. It is probable that the Tree Sparrow pairs for life, and uses the same nesting-spot for years in succession. It rears several broods in the year, eggs for the first being laid in April, for others as late as July. A hole in a tree or wall, or in a quarry, or even in the deserted nest of a Crow or Magpie, are the favourite sites. The nest may be domed or open, according to the situation in which it is built. It is made of dry grass, straws, and roots, and lined with feathers, wool, and hair. The five or six eggs vary a good deal in colour, but on an average are smaller and darker than those of the House Sparrow, greyish or bluish white in ground colour, spotted and speckled with chocolatebrown, paler brown, and grey. It is not social during the nesting period, but is more or less gregarious during autumn and winter.

The adult Tree Sparrow is smaller than the House Sparrow. It has the head and nape uniform chestnutbrown, the back brown streaked with black, the rump and upper tail-coverts buffish brown, the ear-coverts black, surrounded with white, and a double white bar across the wings; the throat and fore-neck are black, the under parts ash-colour. Bill black; tarsi and toes brown; irides brown. Length about $5 \frac{1}{2}$ inches. 'The female resembles the male in colour, and the nestling is much the same, but a trifle duller. 


\section{THE HAWFINCH}

\section{COCCOTHRAUSTES VULGARIS}

LOCAL names in surrounding counties:

Status in British Avifauna: A local resident, sparingly distributed over England and Wales, but only an accidental visitor to Scotland and Ireland.

Radial Distribution within fifteen miles of $\mathrm{S}_{\mathrm{T}}$. PAUl's: The comparative abundance of the Hawfinch within the Metropolitan area is probably due to the bird's shy and secretive habits. Perhaps it is nowhere quite so common as in the Epping district, although there are parts of Kent-in the Crays, for instance-that might run that area close for the distinction. Passing north, we find the bird resident in the Muswell Hill, Enfield, and Hampstead districts, also in those of Barnet, Harrow, Wembley, 'Twyford, Ealing, Chiswick, and Osterley. On the "Surrey side" it is found as a resident in the vicinity of Richmond, Coombe Wood, Wimbledon, Burgh Common, Mortlake, Ewell, and Croydon, besides, of course, various intervening localities. How close to the central portions of our radius the Hawfinch actually breeds it is difficult to say, but it has been recorded as having done so at Dulwich, which comes within the five-mile circle. There are private grounds where this Finch might breed and be overlooked even nearer to the city than that. In winter the bird often wanders into localities where it does not breed. It has been seen at Streatham, and I can record it from the Willesden, Twyford, and Wembley areas.

The Hawfinch is one of the most secretive of our native birds, and its presence in a district is very often quite unsuspected, except ascertained by chance or the most careful and persistent observation. Then, again, the bird-catcher is responsible for its decreasing numbers, or 162 


\section{THE HAWFINCH}

even entire absence, from areas where, if left unmolested, it would be fairly numerous. Gardeners also never lose an opportunity for its destruction, because of its inroads on fruit and other produce. The favourite haunts of the Hawfinch in Greater London are orchards, large gardens, shrubberies, plantations and fields where tall hedges and trees are abundant. Skulking and shy as a Warbler, only transient glimpses of the big, ungainly-looking bird are obtained as it flits about the dense vegetation or crosses a more open spot from one tree or bush to another; and it will be remarked that this Finch has a habit of flying up into the branches instead of dropping into them, as most other birds do. 'The food of the Hawfinch consists of insects and larvæ to some extent in summer, and upon these its young are reared; but at all times seeds, nuts, berries, fruits, and peas perhaps form its staple support. The bird is very fond of the kernels of such fruits as cherries and plums, which its powerful beak enables it to crack with ease ; the stones of haws, beech-mast, and the seeds of the hornbeam are also eaten; whilst the young when they have left the nest consume large quantities of peas. The Hawfinch is not much of a songster, but in the breeding season the male utters a few chattering notes. The call-notes resemble those of the Greenfinch, and a party of birds frequently twitter amongst themselves after the manner of the Brambling, the Linnet, and other Finches. During autumn and winter the Hawfinch spends a gipsy sort of existence, wandering about the countryside in parties, or even small flocks, but in spring these disband, and in pairs seek out their nesting-places. 'The nest is made towards the end of April, the eggs usually being laid in May. It is often placed in a fruit-tree, a dense evergreen or thorn-bush, or on the top of a pollard hornbeam, at a height of a few feet or fifty. It is made of twigs, roots, stalks of various plants, and bits of lichen, lined with fine grass and roots and hair. It is a flat, 


\section{'THE BIRD-LIFE OF LONDON}

bulky structure, and fairly well made. The five or six eggs range from pale olive or bluish green to brownish buff, streaked and slightly spotted with dark olive-brown, pale greyish brown, and violet grey. The pencillings are almost as intricate as those on the eggs of the Buntings. 'Throughout the nesting season the old birds are even more secretive and shy than at other times. But one brood is reared in the year; and it is not unusual to find several pairs breeding in the same vicinity.

The adult male Hawfinch has the head reddish brown, cxcept the lores and the feathers at the base of the bill, which are black, like the throat; the nape is ashy grey; the back and scapulars are chestnut-brown, paler on the rump, and yellowish brown on the upper tail-coverts; the wings are black shot with blue, except the median wing-coverts, which are white, and the outermost primaries, which have a large white patch on the inner web; there is also some amount of greyish white on the others. A marked peculiarity is the truncated form of some of the secondaries, the ends of which are shaped like a billhook. 'The tail is black, the four outer feathers having a terminal white spot on the inner web, the four centre ones narrowly tipped with white. The under parts are brown suffused with yellow, shading into white on the under tail-coverts. Bill black (in winter it changes to pinkish brown); tarsi and toes pale brown; irides greyish white. Length 7 inches. The female somewhat closely resembles the male in colour, but is duller. The nestling resembles the adult in the wings and tail; there is no black on the throat and head, nor grey on the nape, the breast and flanks are barred with brown, and the head and upper parts are suffused with yellow. 


\section{THE GREENFINCH}

\section{LIGURINUS CHLORIS}

Local names in surrounding counties : "Green Linnct" (Essex).

Status in British Avifauna: A common and widely distributed resident throughout well-cultivated and timbered districts, its numbers increased in autumn by migrants.

Radial Distribution within fifteen miles of $\mathrm{S}_{\mathrm{T}}$. PAul's: The Greenfinch may fairly be described as a common resident in every part of the Metropolitan area at all suited to its requirements. It nests regularly in many of the urban parks, from Regent's Park and Battersea Park outwards, and there are few private grounds containing evergreens throughout the inner suburbs to which it does not resort. As the surroundings become more rural the bird becomes increasingly common as a nesting species. In winter it is even more widely dispersed, and may then be seen in still more central districts. I have records of this Finch from the Green Park, St. James's Park, Victoria Park, Russell Square, and Lincoln's Inn. In the more outlying suburbs flocks are often observed, and the bird frequently associates with Sparrows and other seed-eating species. Possibly some of the straggling individuals may be migrants, and many of the flocks seem undoubtedly to be so. 'The Greenfinch, I may add, haunts several of the great cemeteries in London. I have seen it in those of Kensal Green, Brompton, and Highgate.

The tremulous, twittering song of the Greenfinch is a by no means uncommon sound close to inner London during April and May. It may lack the sweetness and variety of other homely species, but when several birds are warbling in concert the effect is very pleasing. I 65 


\section{THE BIRD-LIFE OF LONDON}

More familiar still is che long-drawn note of peezh that may be heard with great persistency in the haunts affected by this species. During autumn and winter the Greenfinch is more or less gregarious, and even in spring and summer is very social, and several pairs may frequently be found nesting in close proximity. 'These flocks resort to fields of mowing-grass, to the growing corn, and later to the stubbles. In sowing-time they visit the newly tilled land, and in hard weather may often be seen with Sparrows near ricks, in farmyards, and occasionally at our thresholds. They love to roost in shrubberies and evergreens at this season. The food of this Finch is composed, according to season, of insects and larvæ, seeds, grain, and various berries. The young seem to be reared exclusively on an animal diet. The bird is very fond of the seeds of the sunflower. This bird flies well, and is as much addicted to the trees as the hedges; it also obtains much of its food on the ground. Several broods are reared in the year, the breeding season lasting from April to August. An evergreen of some kind or a dense hedgerow are the favourite sites for the nest, although many other spots are chosen, sometimes high up a tree, fifty or more feet from the ground. The nest is made of moss, dry grass, roots, and scraps of wool, bound together, especially round the rim, with a few slender twigs, and lined with finer roots, hair, wool, and feathers. The five or six eggs are white (sometimes with a tinge of blue or green), sparsely spotted and speckled with reddish brown and paler brown. The old birds become quiet and secretive during the nesting period, the hen sitting very closely.

The adult male Greenfinch has the general colour of the upper parts yellowish green, suffused on the head, neck, throat, and breast with grey; the wings are brown, the outer webs o the primaries yellow, and the secondaries margined and tipped with grey. The two central tailI66 


\section{THE GREENFINCH}

feathers and the terminal half of the others are blackish brown, edged with grey, the remaining portion yellow. The under parts are yellow, washed with grey on the flanks, merging into nearly white on the abdomen and under tail-coverts. Bill flesh-colour; tarsi and toes pale brown; irides brown. Length 6 inches. The female is more dull in colour than the male, and browner, but the yellow pattern on the wings and tail is much the same. The nestling somewhat closely resembles the female, and the flanks, breast, and throat are streaked with dusky brown. 


\section{THE GOLDFINCH}

\section{CARDUELIS ELEGANS}

Local names in surrounding counties:

Status in British Avifauna: An increasingly local resident throughout England, Wales, and Ireland, becoming more so, and scarcer in Scotland. Its numbers are increased in autumn by migrants.

Radial Distribution within fifteen miles of St. PaUl's: As a nesting species the Goldfinch is decidedly a scarce and local bird, having been more or less exterminated in most localities. From all parts the reports of its rarity or decreasing numbers are made. This to a very large extent is due to the persecution of bird-catchers, and it is to be hoped that the more stringent enforcement of the Wild Birds Protection Acts in the Metropolitan area will result in a much-to-be-desired increase in the number of Goldfinches. It is as a winter visitor that this Finch is best known within the more central portions of our radius. At that season it has, during recent years, been observed so close to the city as Kensington Gardens and Dulwich, whilst it is more frequently seen at Wimbledon, Norwood, Richmond, and Tooting. In the winter of $1904 \mathrm{I}$ observed three Goldfinches amongst some withered docks and thistles on waste ground near Wormwood Scrubbs. They were quite close to the road, fluttering unconcernedly from stem to stem, and were being enviously admired by a couple of passing working men, who volunteered the information that they were "Finches," a name by which the Goldfinch is commonly known amongst fanciers and catchers. In some parts of Middlesex the species is said to be increasing.

There is only one locality within the limits of Greater London, and that is on the north, known to me where the Goldfinch nests in any numbers. It would not be desirable to give greater details, beyond saying that in the year 1907 I68 


\section{THE GOLDFINCH}

some half-dozen nests came under"my notice. 'That the Goldfinch must have been very common near London "once upon a time" seems proved by the fact recorded by Mr. Sharpe that twelve dozen had been netted in a single morning on the spot where Paddington Station now stands! The builder has done almost as much as the bird-catcher in exterminating the Goldfinch in London; but the bird still persists in its visits during winter, and the most likely places to meet with it are the rough bits of dock-and thistle-grown land, the last relics left of what was once open country. Like so many others of its kind, this Finch is more or less gregarious and social during winter, and it roams about a great deal in quest of its food. This chiefly consists in summer of insects and larvie, but at other times seeds of many kinds, especially of noxious weeds, are the favourite fare. It is an active, restless bird when feeding, and is incessantly twittering to its companions as it flits from tree to tree or from one tall weed to another. 'The call-note, by which the species may be readily identified, is a very musical twee-et; whilst its song in the nesting season is a by no means unmusical one, something like that of the Linnet. The Goldfinch is a rather late breeder, the nesting season commencing in May, and being prolonged into July in instances where a second brood is reared. So far as London is concerned I have found the favourite nestingsites of the Goldfinch to be close, low hedges in the vicinity of orchards and gardens, but a universally favourite spot is a fruit-tree of some kind. 'The cup-shaped nest, neatly made and exquisitely rounded, is formed of moss, down, roots, and dry grass stems, garnished with lichens and bound together with spiders' webs, the whole lined with feathers, vegetable down, and hair. The four or five eggs are greyish or greenish white, spotted with reddish or purplish brown and grey. The broods often remain in company through the winter. 


\section{THE BIRD-LIFE OF LONDON}

The adult male Goldfinch has the general colour of the upper parts chestnut-brown, shading into white on the upper tail-coverts and into greyish white on the nape; the crown and a band round the ear-coverts are black; the forehead is crimson; the feathers at the base of the bill and the lores are also black; the wings are black, barred with yellow and tipped with white; the tail is black, the outer feathers with a white spot on the inner web, the rest tipped with white; the throat is crimson, the remainder of the under parts white, shading into brown on the flanks. Bill fleshcolour, darkest at the tip; tarsi and toes pinkish brown; irides brown. Length $5 \frac{x}{4}$ inches. The female is a trifle duller in colour than the male. The nestling lacks the black and red on the head, the under parts are browner, and the breast is faintly spotted. 


\section{THE SISKIN}

\section{CHRTSOMITRIS SPINUS}

Local names in surrounding counties: "Barley Bird" (Essex).

Status in British Avifauna: Resident. Breeds very locally in England and Ireland; more widely dispersed over the conifer area in Scotland. It becomes more commonly distributed in winter.

Radial Distribution within fifteen miles of $\mathrm{S}$ t. Paul's: The Siskin, so far as I know, does not breed in any part of the Metropolitan area, to which it is an irregular and local autumn and winter visitor only. As a straggler it may probably visit some of the more central localities, although I have no reliable records of the fact. In the rural suburbs, however, it is of more or less frequent occurrence, especially by the margins of streams and rivers where alder-trees are common. Amongst the localities where it may probably be met with I can mention Ealing, Hanwell, Southall, Twyford, Wembley, Harrow, Hendon, Hampstead, Elstree, Epping, and Wanstead. On the Surrey side of the Thames the districts of the Crays, Croydon, Sydenham, Dulwich, Streatham, Wimbledon, and Richmond may be given. The Siskin is much sought after by the bird-catcher, as it is a highly prized cagebird, hardy and docile in captivity. To this fact must be attributed its scarcity in many places. Fortunately it breeds in districts remote from towns.

During its possible sojourn within London limits the habits of the Siskin very closely resemble those of the Tits. During autumn and winter it leads a roving kind of existence, chicfly confining itself to trees, especially alders and birches, the minute seeds of which it regards as a delicacy. In obtaining these seeds the Siskin clings to the slender drooping branches, swinging to and fro and 


\section{THE BIRD-LIFE OF LONDON}

assuming a variety of grotesque attitudes, the twittering call-notes being uttered at intervals. The food of this species, in addition to small seeds, consists of buds and insects and larvæ, the latter forming the staple sustenance of the young. During the non-breeding season the bird lives more or less in flocks, and their appearance in any locality is very erratic. The Siskin is reported as having bred in the counties of Kent, Surrey, and Middlesex, so that a look-out for it should be kept within the London radius. Eggs for the first broods are laid in April, for the second in June. Its favourite nesting-place is a firtree, some thirty or forty feet from the ground. The nest is made of fine twigs, grass stalks, and roots, lined with moss, hair, down, and less frequently feathers, and is similar to that of the Greenfinch, but smaller. The five or six eggs are very pale bluish green, spotted and speckled with dark reddish brown and pale grey, occasionally streaked with even darker brown. I may add that during the breeding season the male has a short, twittering, yet musical and pleasing little song.

The adult male Siskin has the head and throat black, the back yellowish green streaked with dusky black, the rump yellower; the under parts below the throat are yellow, palest on the abdomen and darkest on the flanks, which are streaked with black; the wings and tail are black marked with yellow. Bill brown, paler at the base ; tarsi and toes pale brown; irides brown. Length $4^{\frac{1}{2}}$ inches. The female is similar to the male in general coloration, but is rather duller, and wants the black on the head and throat, a characteristic also of the nestling. 


\section{THE LESSER REDPOLE}

\section{LINOTA RUFESCENS}

Local names in surrounding counties:

Status in British Avifauna : Resident, breeding but locally in the south of England; increasingly abundant northwards and in Scotland. It is commonest in summer in the north of Ireland, rarer in the south of that country. It is much more widely distributed in autumn and winter.

Radial Distribution within fifteen miles of $\mathrm{S}_{\mathrm{T}}$. PAul's: It is only very exceptionally that the Lesser Redpole breeds anywhere within the Metropolitan area. It is recorded as having done so at Wimbledon. In autumn and winter, however, it is by no means uncommon, although irregular in appearance and somewhat local. I have seen this bird in St. James's Park; and I well remember a small flock which the late Henry Seebohm and myself stood and watched for some time as we were crossing the Green Park one morning in the late autumn of $\mathrm{r} 88 \mathrm{r}$. He told me that the bird was frequently seen at Dulwich, where he then resided. I have also records from Battersea Park, Clapham, Peckham, Kensington Gardens, Regent's Park, and Kilburn. The bird also visits the districts of Hampstead, Highgate, Kingsbury, Wembley, Twyford, Wormwood Scrubbs, Ealing, Acton, Osterley, Kew, Chiswick, Richmond, Wimbledon, Tooting, Dulwich, Greenwich, Wanstead, and Epping. It is scarcely necessary to mention the extreme outlying suburbs, to which the bird is a more numerous visitor still.

Like the Siskin, the Lesser Redpole lives in flocks during autumn and winter, and it is then that this small Finch is met with in the area of London. Its habits closely resemble those of the Siskin, but the bird shows more partiality for the ground, and may frequently be seen 


\section{THE BIRD-LIFE OF LONDON}

on weedy pastures and clover stubbles in quest of the many small seeds that form its food. It also loves the alder - and birch-trees, resorting to them for their seeds. It is a tame and confiding little bird, and assumes many Tit-like attitudes in quest of food. In summer it also eats many insects and larvæ, and these form the principal food of its young. The Lesser Redpole, like so many other Finches, is constantly uttering a twittering call-note, both during flight and whilst on the trees, bushes, or ground. In spring the male utters a short, trilling song, which, however, becomes much less frequent after the young are hatched. But one brood generally is reared in the year, and preparations for this are commenced in May or June. The tiny nest is very often made in a crotch in some dense low hedge, and is a beautifully rounded cup, formed outwardly of twigs, roots, moss, and dry grass, lined with feathers, vegetable down, hair, and sometimes wool. The five or six eggs are greenish blue, spotted and speckled with purplish brown and pale brown, and occasionally streaked with darker brown. The young and their parents remain in company during the autumn and winter.

The adult male Redpole has the upper parts rufous brown streaked with dark brown, the wings and tail blackish brown, with pale brown margins; the middle and greater wing-coverts are broadly tipped and the innermost secondaries broadly margined with rufous brown; the crown is crimson, the rump strongly suffused with the same; the chin and upper throat are dark brown, the remainder of the under parts buffish, darkest on the flanks, which are marked with brown, and suffused with crimson on the breast. Bill yellow, darker at the tip; tarsi and toes brownish black; irides brown. Length $4^{\frac{x}{2}}$ inches. The female has no crimson on the upper parts, and the flush on the breast is barely visible; the under parts are more streaked, as is still more the case with the nestling, I74 


\section{THE LESSER REDPOLE}

which also lacks the crimson. After the autumn moult the crimson on the adult male is partially concealed by the long pale fringes to the feathers, which gradually wear off as spring comes on ; but at this season the ruddy colour increases in intensity also. 


\section{THE LINNET \\ LINOTA CANNABINA}

Local names in surrounding counties: "Red Linnet" (male) (Essex).

Status in British Avifauna: A common and widely distributed resident, especially in winter, when its numbers are swelled by migrants from Continental areas.

Radial Distribution within fifteen miles of $\mathrm{S}$ t. PaUl's: Of the small Finches the Linnet is by far the commonest and best known throughout the Metropolitan area. It breeds in many parts of it, although somewhat locally, doubtless because suitable ground is wanting in certain districts. I have records of it nesting on Wimbledon and Tooting Commons, and various gorsecovered spots in Surrey and Kent well within the eightmile radius. It is also tolerably common at Epping, and may be found breeding at Hampstead, and in the Wembley, Osterley, and Hounslow districts. It also nests at Harrow and Stanmore, and in many other suitable spots in the more rural suburbs. The places mentioned serve chiefly as guides; haunts of the Linnet may be found in many of the intervening localities. In winter the bird is not so local, and flocks may be met with much nearer the central districts. I have often seen it on waste lands and brickfields adjoining Wormwood Scrubbs; it is also a visitor to some of the more urban parks, and to many of the private grounds and gardens with which suburban London abounds. On April 26, 1905, I watched a female Linnet for some time hopping about the grass and the beds of tulips in the ornamental gardens of the Victoria Memorial opposite to Buckingham Palace, and the bird has been recorded from Kensington Gardens

During the summer the favourite haunts of the Linnet are gorse-coverts, and here it nests in scattered pairs; 176 


\section{THE LINNET}

but in autumn and winter it assembles into flocks and a more cosmopolitan existence is passed. Like the Redpole it obtains much of its food at these seasons upon the ground, resorting to rough wastes and weed-grown fields where an abundance of small seeds can be obtained. A marked characteristic of these bands of Linnets is their garrulousness, and often some tree-top literally jingles with a concert of twittering cries, the combined musical effect of which is very pleasing. In addition to numerous small seeds, this species in summer subsists largely on insects and larvæ. Early in spring the flocks break up into pairs and scatter over the nesting-areas, and then the males may be seen sitting on the exposed sprays of the gorse and other bushes warbling their sweet little lovesong. At this season the Linnet looks his best, and he is fond of displaying his charms on any bare twig, evincing little fear of man. This species usually rears two broods in the season, eggs for the first being laid in April, for the second in June. The bird pairs annually, and the favourite site for the nest is amongst gorse and broom. The nest is made of dead sprays of the gorse, fine twigs, dry grass, and moss, and neatly lined with hair, wool, vegetable down, and feathers. In this beautifully rounded cup the hen lays" five or six eggs, pale bluish green, spotted and speckled, mostly in a zone round the larger end, with dark reddish brown and paler brown and grey. The male often betrays the vicinity of the nest by his persistent habit of singing close to it.

The adult male Linnet has a crimson patch on the forehead extending to the crown; the remainder of the head, as well as the nape and the sides of the neck, are dingy grey; the back is reddish brown, paler on the rump, and streaked with dull black; the wings are dark brown margined with dull white, the wing-coverts and innermost secondaries with darker centres; the upper tail-coverts and tail are black, the latter with white margins, broadest 


\section{THE BIRD-LIFE OF LONDON}

on the outermost feathers; the under parts are buff, much darker on the flanks, nearly white on the abdomen and under tail-coverts, and flushed with carmine on the breast. Bill slate-grey; tarsi and toes brown; irides brown. Length $5 \frac{x}{2}$ inches. The female is more dingy in colour than the male and wants the crimson on the head and breast, and is streaked with dark brown on the under parts. The nestling resembles the female in colour. After the autumn moult much of the male's crimson flush is concealed by the fringes to the feathers, but as spring advances these disappear, and the colours also intensify. The rosy tints of the male Linnet disappear in captivity. 


\section{THE TWITE}

\section{LINOTA FLAVIROSTRIS}

Local names in surrounding counties:

Status in British Avifauna: A local resident, and far more widely dispersed in winter than in summer; commonest, perhaps, during the latter season in the west of Scotland. It is generally distributed over heath-lands and moors in England, Wales, Scotland, and Ireland, in winter resorting to more cultivated districts.

Radial Distribution within fifteen miles of St. Paul's: The Twite is one of the rarest and most local of London's bird visitors. I know of no record of this species breeding anywhere within the Metropolitan area, and it can only be classed as an irregular and scarce autumn and winter wanderer. Information respecting its distribution within our limits is singularly meagre, a fact which confirms the rarity of the species therein. It may, of course, be overlooked to a very considerable extent, for it is given to much wandering during the non-breeding season. There are many localities in which one might reasonably expect to find it occasionally, but I have searched most of them in vain, and although I have had a long and varied experience of the bird in its normal haunts I have never yet had the pleasure of meeting with it in or near the Metropolis. I have spoken to many bird-catchers in and about the suburbs, but the Twite, it is very evident, is practically unknown to them.

It is unnecessary in the present work to dwell at any length upon the habits of the Twite. These closely resemble during winter those of the Linnet; and, indeed, the Twite is not unfrequently found consorting with that species. Its food is similar, it has the same simple twitter of a song, and its call-note - a long-drawn twa-itegives the species its English name. It nests on the moors 


\section{THE BIRD-LIFE OF LONDON}

in May and June, usually making its home amongst the heather. This nest is composed externally of twigs, dry grass stems, moss, and roots, lined with vegetable down, feathers, and wool. The five or six eggs are pale bluish green, spotted, speckled, and frequently streaked with reddish brown and grey.

The adult male Twite is very similar in general coloration to the Linnet, but its longer tail gives it a slightly larger and more slender appearance. It has, however, no crimson on the head or breast, but the rump is suffused with crimson, as in the Redpole; the breast and flanks are streaked, and the white in the tail is represented by pale brown margins. Bill yellow in summer, grey in winter; tarsi and toes dark brown; irides brown. Length 5 inches. The female has no crimson tinge on the rump, and the nestling resembles her in general coloration. 


\section{THE BULLFINCH}

\section{PYRRHULA VULGARIS}

LOCAL names in surrounding counties:

Status in British Avifauna: A fairly common and widely distributed resident in all wooded and cultivated districts.

Radial Distribution within fifteen miles of $\mathrm{S}_{\mathrm{T}}$. PAUL's: All the available evidence tends to show that the Bullfinch is commoner in the southern suburbs than in the northern ones, the proximity of the Kentish and Surrey orchards possibly being the reason. Whether the Bullfinch breeds in Battersea Park I am unable to say but there is a possibility of it. It is known to do so, however, at Dulwich, Streatham, and Wimbledon, and probably in Kew Gardens. It is certainly rare and local at Richmond, and the same remarks apply to all or nearly all of the Middlesex suburbs. I can record the species in summer from the Wembley, Willesden, and Hampstead areas, and the bird is certainly a local and scarce resident in the Epping and Wanstead districts. Across the river it may be recorded from Greenwich, Eltham, Beckenham, and Sydenham; whilst further out still it becomes increasingly numerous in the Crays and the Croydon and Banstead districts. During the non-breeding season the bird wanders a good deal, and may then be observed in the more central areas, gardens and private grounds especially. I have records from Clapham, Peckham, Tooting, Kensington Gardens, and Regent's Park. The species, however, is very erratic in its appearance.

The Bullfinch may casually visit anyisuitable spot in Greater London during autumn and winter, but in summer it is local as a resident, and its retiring ways at that time greatly assist in its being overlooked. 'After the nesting season the bird seems for ever on the wander, 


\section{THE BIRD-LIFE OF LONDON}

and it is nothing nearly so social as other Finches, usually roaming in pairs. The broods keep company for some time with their parents, however, and early in spring, about the mating period, an assembly may occasionally be met with. The flight of the Bullfinch is rather slow and deliberate, and follows a dipping direction, the white rump of the bird enabling the eye readily to follow its course. It is a somewhat shy and secretive species at all times, and is fond of hiding in the corer, where a transient glimpse or the characteristic piping call-note of $d y \breve{u}$ - $d y \breve{u}$ are all that betray its whereabouts. Sometimes in spring its actions may be more readily observed as it moves about the fruit-trees eating the buds. It feeds chiefly on seeds, buds, and berries of various kinds, and in summer on insects and larvæ, upon which its young are reared. The low, twittering song of the male is heard most frequently in the laying season, which is in April to June, or even later. The nest, often made in a fir or other evergreen in a shrubbery, or in a dense hedgerow or thicket, is largely composed outside of slender twigs, which support the cup, made of roots and hair, with an occasional feather or tuft of wool. The four or five (or eren six) eggs are bluish green, spotted with purplish brown and grey, and sometimes sparingly streaked with darker brown. Two broods are reared in the season.

The adult male Bullfinch has the head, tail, and wings glossy black, a spot of dull red on the innermost secondary, and spots of grey on the wing-coverts; the back is clear bluish grey, the rump white; the chin is black, the remainder of the under parts brick-red, sare the under tailcoverts and ventral region, which are white. Bill black; tarsi and toes dark blackish brown; irides brown. Length 6 inches. The female resembles the male in the general colour pattern of her plumage, but the red and grey parts are brown, palest on the abdomen. The nestling also resembles the female, but has no black on the head. I 82 


\title{
THE CROSSBILL
}

\author{
LOXIA CURVIROSTRA
}

LOCAL names in surrounding counties:

Status in British Avifauna: A rather rare and local resident, breeding in many districts, especially in Scotland, but best known as an irregular wanderer in winter in small flocks.

Radial Distribution within fifteen miles of St. Paul's: Of all the species that pay casual visits to the Metropolitan area the Crossbill is one of the most erratic and irregular. It has been known to breed in at least three of the Metropolitan counties-Surrey, Kent, and Essex-but I am not aware of any reliable instance within the fifteen-mile radius. It is only as an autumn and winter visitor that the Crossbill, at uncertain intervals, is observed within the suburbs of the Metropolis. It has then been recorded from Norwood, Dulwich, and Wimbledon, south of the Thames, and from Epping, Hampstead, and the Harrow district north of that river. The Crossbill is a bird that cannot easily be mistaken or overlooked; consequently we must attribute the paucity of records to its scarcity. It may appear any season, and in unusual numbers, like the Waxwing, and its absence hitherto from a locality cannot be taken as an indication that the bird is not likely to visit it.

The bird-lover fortunate enough to meet with the Crossbill within the London area will experience no difficulty in identifying it by its crossed mandibles. It is also by no means shy during its winter sojourn in our southern counties, over which it roams in parties, or larger flocks. Indeed, at all times this species seems more or less gregarious, and eren in summer parties of male birds have frequently been observed. In their actions on the trees they closely resemble Tits or Siskins, 


\section{THE BIRD-LIFE OF LONDON}

their acrobatic movements being due to their eagerness and desire to obtain berries and other seeds, the finest of which often grow at the extremities of the slender branches. Their flight is undulating; and their twittering call-notes resemble those of the Linnet and other Finches, with which they often consort. In the breeding season the male has a sweet little song, uttered in a subdued tone. The food of the Crossbill consists of the seeds of conifers, the cones of which are easily broken by the powerful crossed bill, various berries and small fruits, the pips of apples and pears, and in summer insects and larvæ. The Crossbill has been found nesting as near to London as Kent and Surrey, but it is very unlikely that the student of London birds will ever be fortunate enough to meet with its home. It is a very early breeder, and retires chiefly to conifer woods and plantations for reproduction. The eggs are usually laid between February and April. The nest, placed at various heights from the ground in a fir-or spruce-tree, often on a flat branch some distance from the trunk, is made of slender twigs, roots, and dry grass, lined with wool, hair, and a few feathers, closely resembling that of the Greenfinch. 'The four or five eggs are so like those of that species that a further description is unnecessary. Several nests are often found quite close together in the same belt of timber. The old birds are very secretive during the breeding season, and he hen sits closely.

The adult male Crossbill has most of the small feathers of the body scarlet, most brilliant on the rump, and with a brownish suffusion on the back; the wings and tail are brown, the centre of the abdomen pale grey. Bill brown ; tarsi and toes brown; irides dark brown. Length 6 inches. The female is greenish yellow, with the wings and tail similar in colour to those of the male. The nestling is brown, palest on the abdomen, and streaked above and below with darker brown. After their first I 84 


\section{THE CROSSBILL}

moult they attain the sexual colours of the adult, with this exception, that the young males are intermediate in tint between adult males and adult females. In captivity the adult male appears to lose his scarlet dress after the first moult, and to retain a plumage similar to that of the female, as is the case with the Linnet. 


\section{THE SPOTTED FLYCATCHER}

MUSCICAPA GRISOLA

Local names in surrounding counties: "Wall-bird" (Essex).

Status in British Avifauna : A summer visitor to all suitable localities.

Radial Distribution within fifteen miles of St. PAUL's : Although so closely associated with the country, the Spotted Flycatcher is a regular and fairly common summer visitor to many spots even in the central districts of the Metropolitan area. I have seen this species in St. James's Park, and it may possibly breed in the grounds of Buckingham Palace. It nests regularly in Hyde Park and Kensington Gardens-in Rotten Row in the former and near the Tea Pavilion in the latter-and I have also records from Regent's Park during the breeding season. I am not aware of its breeding in Battersea Park, although it may very possibly do so, but it nests regularly at Dulwich, Tooting, and Balham. In the western and northern suburbs Barnes, Chiswick, Dollis Hill, Hampstead, and Highgate may be mentioned. In the more rural suburbs the bird of course becomes commoner, and I can include Tooting, Wimbledon, Richmond, Kew, Osterley, Hanwell, Acton, Ealing, Horsenden, Twyford, Wembley, Kingsbury, Finchley, Hendon, Barnet, Enfield, Epping, Wanstead, Ilford, Greenwich, Dartford, Bromley, Croydon, Mitcham, Merton, and Kingston as regular haunts. Beyond these limits it becomes unnecessary to specify.

A stroll in Hyde Park or Kensington Gardens during the summer will be sufficient to make the acquaintance of this sombre little bird. It is a late migrant, not reaching its English haunts before the first week in May, leaving them again in September. The Spotted Flycatcher I 86 


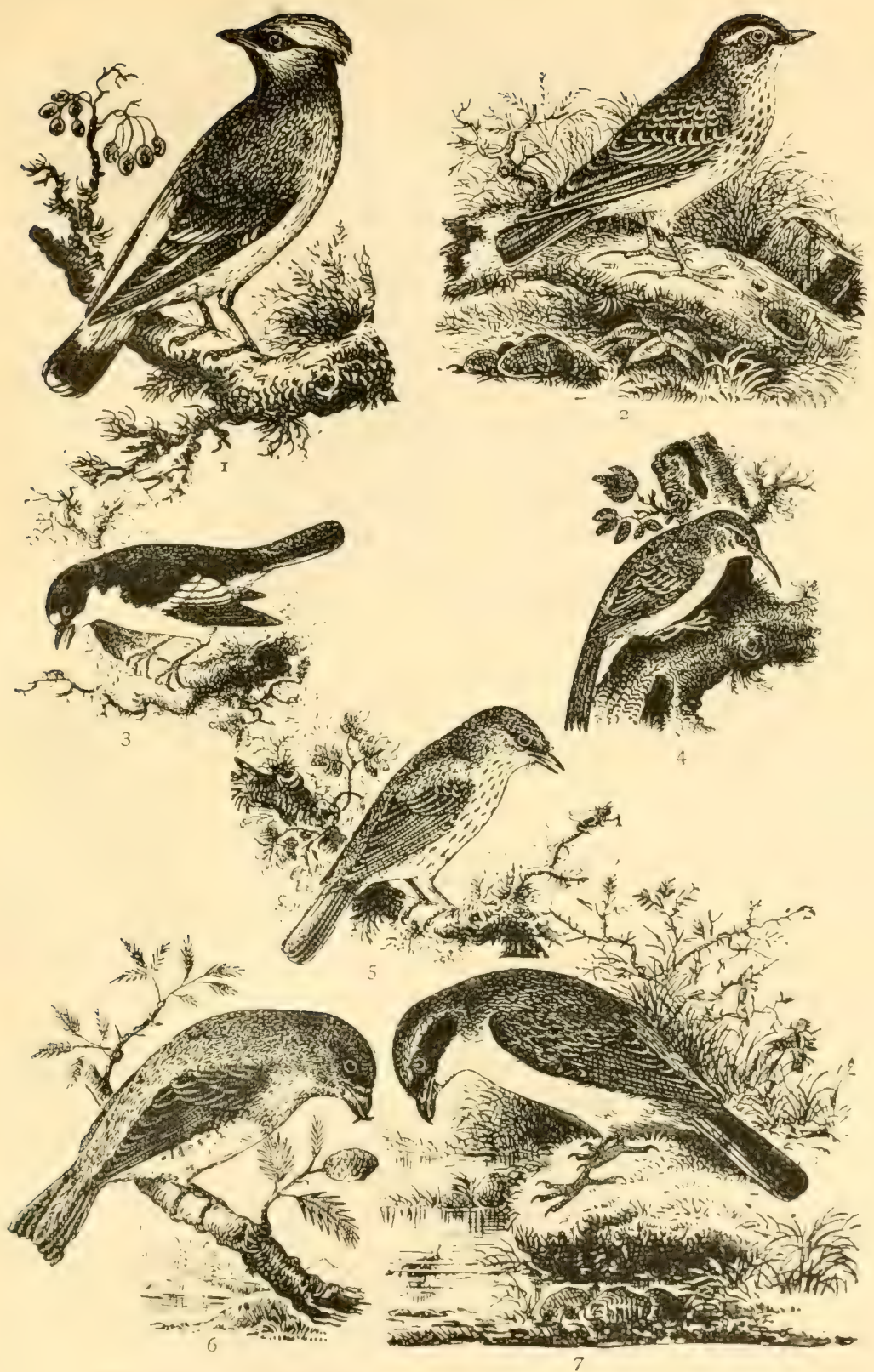

I. Waxwing. 2. Wood Lark. 3. Pied Flycatcher. 4. Common Creeper.

5. Spotted Flycatcher. 6. Common Crossbill. 7. Red-backed Shrike. 

seems much attached to its haunts, and wanders little during its sojourn in them. Like the Tree Pipit it usually selects some spot where there are a few isolated trees, some fences, or other coign of vantage upon which it can perch, and from which it can make repeated sallies into the air in chase of its prey. It will be scen quictly sitting on some paling or bare branch, giving its tail a beat at intervals, and from time to time uttering a sharp double call-note, resembling chee-tic-chee-tic-chee-tic-tic-tic. Suddenly some passing insect is noticed, and the little brown bird starts fluttering in pursuit, and the sharp snap of the mandibles as they close over the fly is audible some distance away. The bird returns to the same perch, or to another close by, and the performance is repeated at intervals. The male occasionally utters a low, rambling song, something like that of the Whinchat. The food of this species is composed of insects of many kinds. It is said occasionally to eat berries, and possibly does consume small fruits, as so many other insect-eating birds habitually do. A few weeks after its arrival it commences nest-building, and the eggs are laid at the end of May or early in June. The nest is built in a crevice of the bark, in a knot-hole, or on a horizontal branch of a fruit-tree against a wall, amongst trelliswork in similar situations, or even on a beam in a shed, supported on one side at least, and is made of dry grass and moss, bound together with cobwebs and wing-cases of insects, and lined with roots, hair, and feathers. The eggs, four to six, range from bluish white to clear pea-green, blotched, freckled, and spotted with reddish brown of various shades. This bird is not at all social during the breeding season, each pair keeping to certain haunts. The brood and their parents remain in company after the former leave the nest

The adult Spotted Flycatcher has the general colour of the upper parts greyish brown, the feathers on the I 87 


\section{THE BIRD-LIFE OF LONDON}

crown having dark centres; the wings and tail are dark brown; the under parts are greyish white, darkest on the flanks and breast, the latter streaked with brown. Bill dark brown ; tarsi and toes black; irides brown. Length nearly $5 \frac{3}{4}$ inches. The nestling is profusely spotted on the upper parts with buff, but otherwise resembles its parents. 


\title{
'THE PIED FLYCATCHER
}

\author{
MUSCICAPA ATRICAPILLA
}

Local names in surrounding counties:

Status in British Avifauna: A local summer visitor, chiefly to Wales, the north of England, and the south of Scotland.

Radial Distribution within fifteen miles of $\mathrm{S}_{\mathrm{T}}$. PAul's: Nearly a hundred years ago Graves records that the Pied Flycatcher nested at Peckham, and in our own time it has been found doing so at Tooting, in Highgate Woods, and at Epping. It has been frequently observed in woods at Hampstead, and even noticed in Kensington Gardens, during migration. Little more can be said of the distribution of the Pied Flycatcher in the Metropolitan area. It is a species that often wanders out of its usual course during spring and autumn passage, and at those periods may occasionally stray into districts near London. A bird that casually visits such a central locality as Kensington Gardens may in the course of its errantry be observed almost anywhere, so that we need not dwell at greater length upon its local distribution here.

The habits of the Pied Flycatcher very closely resemble those of the preceding species. It arrives earlier, during the last half of April, leaving in September. In our islands this bird shows a preference for the wilder districts, the birch coppices and open woodlands where streams and pools abound, but in other lands it is equally partial to gardens and orchards. Its food chiefly consists of insects, which are mostly chased and captured in the air, but small fruits are also eaten. The short and low-toned song of the male bears some resemblance to that of the Redstart. The Pied Flycatcher breeds in May, and the nest is always made in a holc of some kind, in a tree or wall for preference. 
Although not exactly a social bird, several pairs frequently nest in the near vicinity of each other. The nest is a simple one, loosely put together, cup-shaped, and formed of dry grass, dead leaves, and moss, lined with roots, horsehair, wool, and less frequently feathers. 'The six or eight eggs are pale blue.

The adult male Pied Flycatcher has the general colour of the upper parts black, palest on the rump, and there is a white patch on the forehead; the wings are brown, the central coverts white, and the inner secondaries margined with white; the under parts are white. Bill black; tarsi and toes black; irides brown. Length $5^{\frac{1}{8}}$ inches. The female is brown where the male is black, and the under parts are not quite so pure a white. The nestling is profusely spotted with buff on the upper parts, and the under parts are irregularly marked with dark brownish black. 


\section{THE RED-BACKED SHRIKE}

\section{LANIUS COLLURIO}

LOCAL names in surrounding counties: "Butcherbird" (Essex).

Status in British Avifauna: A local summer visitor to England and Wales, from Derbyshire southwards; of only accidental occurrence in Scotland and Ireland, although it has been recorded as having bred in the former country.

Radial Distribution within fifteen miles of $\mathrm{S}_{\text {t. }}$ PAUL's: I have no records of this bird from the more central districts, and its distribution normally does not commence until the four- or five-mile radius is reached. It is a fairly numerous summer visitor to suitable spots, breeding in the south from Dulwich, Barnes, Putney, Wimbledon, and Richmond outwards; in the west from Osterley, Hanwell, Sudbury, Pinner, Perivale, Wembley, Harrow, Stanmore, and Elstree; in the north from Hendon, Barnet, Enfield, Waltham, and Epping; in the east from Ilford and Dagenham; and in the south from Dartford, the Crays, Bromley, Croydon, Banstead, Merton, Ewell, and Epsom. As might naturally be expected, the bird becomes commoner in the remoter and more rural suburbs, although I have remarked its persistent attachment to certain haunts after they have been considerably encroached upon by the builder. It has a habit of returning year by year to one particular spot to nest, and may be seen, like the Tree Pipit, summer after summer in certain trees and bushes.

There are many ideal haunts for the Red-backed Shrike in suburban London-high hedges and welltimbered fields, open country with plenty of cover, in which the bird delights. It is one of the latest of our summer migrants, reaching England early in May, and 


\section{THE BIRD-LIFE OF LONDON}

retiring south in September. The bird is fond of sitting on some tall hedge or isolated bush, on a telegraph wire, or any other elevated spot from which a good look-out is possible, and from this perch it darts at intervals in quest of food. This chiefly consists of beetles, bees, wasps, grasshoppers, cockchafers, small birds, mice, and lizards. Many of these when captured are conveyed to some thorn-bush and impaled, where they are left for future use, or the sharp thorn is used as a skewer whilst the object is torn to pieces and eaten. 'The ordinary callnote of this Shrike is a harsh chirp, but when alarmed it utters a grating chack, something like the note of the Fieldfare. Its song is short, and not very loud or musical. It flies in an undulating way from tree to tree, but may often be seen hovering Kestrel-like above the ground, as if searching the grass for prey. The Red-backed Shrike nests in May and June, and so far as Greater London is concerned the favourite haunts are hedges and thickets. The nests vary a good deal in size, materials, and workmanship, some being very slovenly and loosely put together, others compact and bulky. The usual nest is made of dry grass stalks and the stems of plants, roots, moss, and wool, and finally lined with hair. Other nests are made of dry plants with flowers attached, moss, and wool, with a strengthening girdle of twigs. The four to six eggs vary a good deal in colour and style of markings. The ground colour may be pale blue or green, pale buff, pink, or even white, spotted, freckled, and blotched with various shades of olive-brown and grey, the markings mostly in an irregular band round the laiger end of the egg. Throughout the period of incubation the male, sentinel-like, is seldom far from the nest. The young are fed and tended for some time after they can fly, and during this period the old Shrikes destroy many small birds.

The adult male Red-backed Shrike has the head and nape, the upper back, rump, and upper tail-coverts I92 


\section{THE RED-BACKED SHRIKE}

slate-grey; the back and scapulars chestnut; the wings black, margined with chestnut; the wing-coverts black, broadly margined with chestnut. The two centre tailfeathers are black; the remainder have the terminal half black, tipped with white, the basal half white. A broad black band passes through the eye and meets across the forehead. The under parts are greyi:h white, with a rosy flush. Bill black; tarsi and toes black; irides dark brown. Length 7 采 inches. The female is nothing nearly so showy. There is no black on the head, and the upper parts are nearly uniform reddish brown; over the eye is a pale buff streak; the under parts are buffish white, more or less barred with brown. The nestling resembles the female, but is also barred on the upper surface. 


\section{THE WAXWING}

AMPELIS GARRULUS

LOCAL names in surrounding counties:

Status in British Avifauna: An irregular and nomadic winter migrant. It is most frequently met with in the eastern counties, and rarest in Ireland.

Radial Distribution within fifteen miles of St. PaUl's : A special local interest attaches to the Waxwing, for a specimen shot at Camberwell in 1803 was the subject for the figure given by Graves in his British Ornitbology, which contained a coloured representation of every then known species of British bird. Since those days the Waxwing has continued to pay irregular and uncertain visits to the Metropolis, where it has been shot or noticed in a great many districts. It is one of those species of which little need be said concerning its abnormal distribution within the Metropolitan area. Winters may pass and not an example may be observed; then may come a season when the erratic bird may visit us in extraordinary numbers, as was the case in $\mathbf{1} 830-3 \mathbf{I}$, 1834-35, I849-50, I866-67, I872. During the latter visitation London was exceptionally visited. Localities are no more favoured, and the Waxwing may quite unexpectedly appear in almost any part of the Metropolis sufficiently wooded to afford it a resting-place.

This is another species the habits of which do not require to be dealt with in much detail here. The Waxwing is everywhere a wandering, erratic species, and seldom breeds in the same localities for two successive years. Its habits are by no means perfectly known. It is more or less gregarious and social, even during summer, and its actions are lively and engaging. Its food consists of berries, small fruits, and insects. Its notes are described as similar to the call of the Blue Titmouse, 194 


\section{THE WAXWING}

sometimes uttered in a kind of trill. The bird appears, to breed in large isolated colonies in woods. The nest is a bulky structure made of twigs, tree-moss, scraps of bark and dry grass, lined with feathers. The five or six eggs are greenish or lilac-grey in ground colour, blotched, spotted, and speckled with blackish brown and grey.

The adult male Waxwing has the general colour of the upper parts, including a long full crest, vinaceous brown, merging into chestnut on the forehead and slate-grey on the rump and upper tail-coverts; a band of black extends from the forehead over the lores and behind the eye; the wings and tail are brownish black, the primaries tipped with white, and yellow near the end of the outer web; the shafts of the secondaries are prolonged and flattened into scarlet wax-like appendages; the tail has a broad yellow band across the end, and in some cases the shafts are prolonged into similar wax-like processes. The under parts are vinaceous brown, shading into white on the abdomen and chestnut on the cheeks and under tailcoverts; there is a white streak from the base of the lower mandible; and the chin and throat are black. Bill black; tarsi and toes black; irides brown. Length $7 \frac{1}{4}$ inches. The female somewhat closely resembles the male in colour, but her crest is smaller and the wax-like appendages on the wings are fewer, and absent altogether from the tail. The nestling is olive-brown above, marked with greyish brown; there is no black on the throat, the under parts are yellowish white, with fulvous streaks, and the wax-like processes are barely indicated. 


\section{THE STARLING}

\section{STURNUS VULGARIS}

LOCAL names in surrounding counties:

Status in British Avifauna: A common and widely distributed resident, more local in Scotland (where it has increased its range enormously within the past century), and especially so in Ireland, where it is most numerous in winter. The resident Starlings are increased in numbers in autumn by vast migratory hordes.

Radial Distribution within fifteen miles of $\mathrm{S}_{\mathrm{T}}$. Paul's: Next to the House Sparrow the Starling is the most familiar bird of the Metropolis. It would perhaps be difficult to say exactly how near to St. Paul's the bird actually breeds, but certainly a mile or so would be a fairly correct estimate. From that limit the Starling may be found almost everywhere as a breeding species wherever it can find a suitable lodging. It is nowhere so abundant as the House Sparrow, but there are many places well within our limits where the bird congregates in late summer and in autumn in vast multitudes. It is a familiar bird in all the large parks and public grounds, as well as on the lawns of private houses. It becomes increasingly common in the suburbs, and very often large flocks may be seen winging their way across the sky to certain roosting-places. In many places it is certainly increasing in numbers.

The Starling is the commonest large bird of the suburbs, and there are few villas that do not accomodate a pair or more. 'This handsome, lively bird readily accomodates itself to circumstances, and its cheery song lends life to many an otherwise desolate wilderness of bricks and mortar. The parks and open spaces are made all the more attrative by the big black birds running about the sward or chattering noisily in the surrounding trees. The 196 


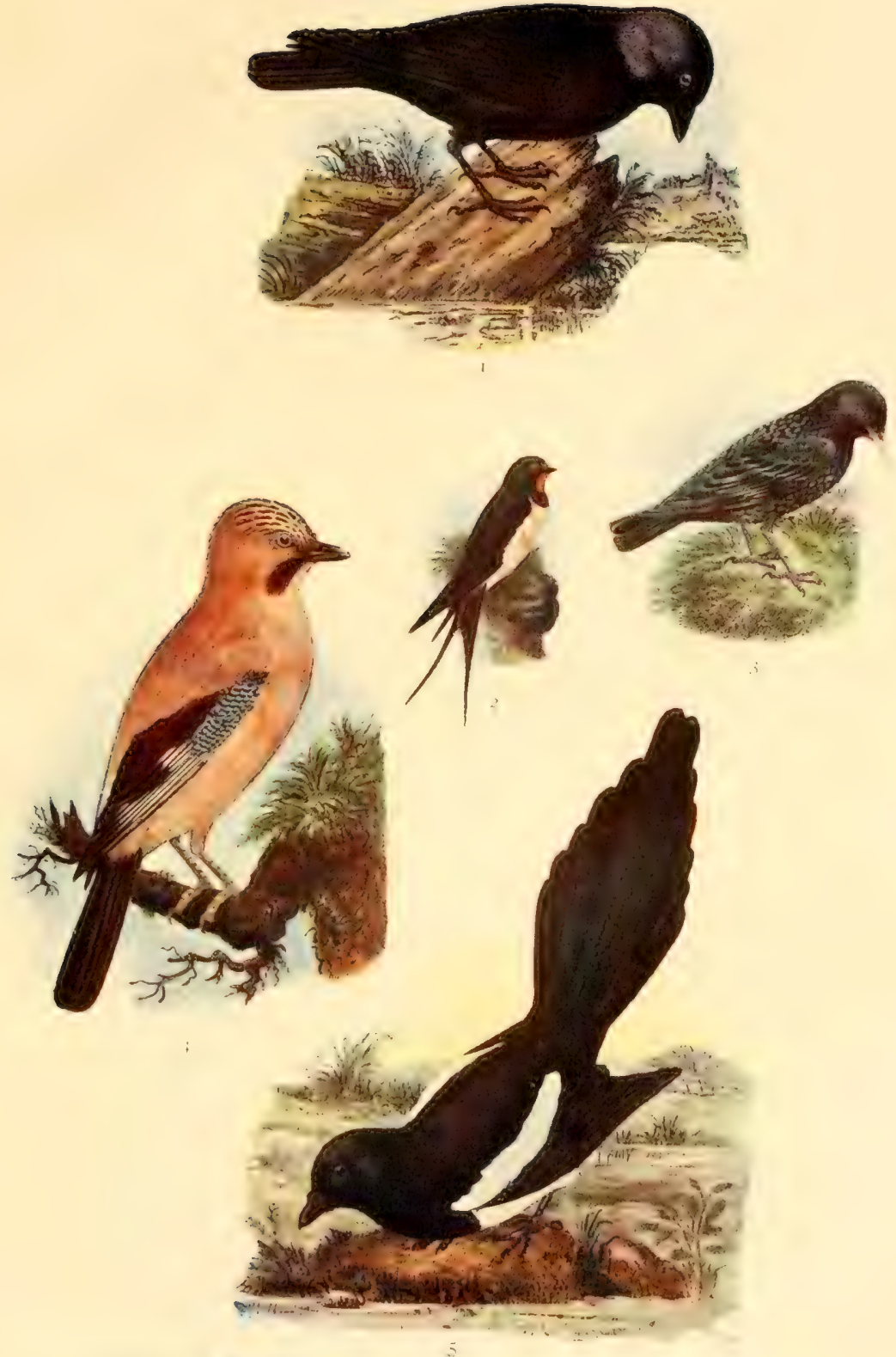

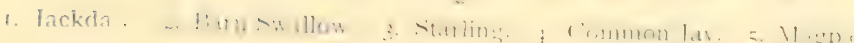





\section{THE STARLING}

Starling is almost a perennial songster. His music may be heard at intervals through the winter, and as the earliest signs of spring appear he becomes still more tuneful, as he sits with drooping wings and bristling plumage on the chimneys and trees pumping out his laboured, chattering song. The bird is more or less gregarious through the year, but after the breeding season the scattered broods gather up into enormous flocks, passing the day on the grass and resorting at nightfall to certain roosting-places which have been used for time out of mind. The aerial movements of these flocks previous to settling down for the night are very imposing and interesting, and the noise becomes deafening until darkness has quite fallen. The bird, especially in summer, may often be seen coursing about the air almost like a Swallow, in quest of insects or for mere enjoyment. The food of the Starling consists of grubs, worms, beetles, grain, seeds, and many kinds of small fruits and berries. In London elderberries are always a great attraction. The call-note of this species is a prolonged musical whistle; the alarmnotes are harsh and discordant, almost as much so as those of the Missel-Thrush. The nestlings are also very noisy, especially each time one of the parents arrives with food. The Starling begins breeding early in April, and in some cases at least rears two broods in the season. The nest is usually made under eaves, or in any convenient hole amongst masonry or brickwork, as well as in holes of trees. It is an untidy structure, made of straws, dry grass, and roots, with sometimes a few feathers by way of lining. The five to seven eggs are pale greenish blue, and somewhat glossy. As soon as they can fly the young resort to the grass and are soon able to provide for themselves.

The adult male Starling in breeding plumage is black glossed with metallic purple and green; the wings and tail are brown, with broad, glossy black margins; the under tail-coverts are margined with pale buff, bill 


\section{THE BIRD-LIFE OF LONDON}

lcmon-yellow, which changes to dark brown in autumn; tarsi and toes reddish brown; irides brown. Length 8 inches. The female is more spotted with buff and grey than the male, and the long, hackle-like feathers on the throat are not so developed. Bill yellow, tipped with brown in summer; brown in winter. The nestling is almost uniform smoke-brown, palest on the under parts, which are more or less streaked. After the autumn moult the adult Starling has much of its pristine beauty concealed by buff tips to the feathers, which gradually abrade as spring advances. The metallic colours also intensify. 


\section{THE RAVEN \\ CORVUS CORAX}

Local names in surrounding counties:

Status in British Avifauna : A very local resident on the sea-coasts of England and Wales, becoming commoner and more generally dispersed in Scotland and Ireland. It wanders into many districts in autumn and winter.

Radial Distribution within fifteen miles of St. Paul's: The Raven must formerly have been a tolerably common bird within the Metropolitan area, for it once nested regularly in Hyde Park, and imagination pictures the sable bird frequenting the various gibbets that in the good old days stood in various parts of the London suburbs. In more recent times we have the record of its nesting at Enfield, and there are many localities in Greater London where the big bird found a congenial haunt. London's Ravens, however, have now all passed away, and for many a long year the species has ceased to nest near the Metropolis. It is everywhere a rare visitor, its distribution calling for no further notice here. If the bird ever wanders to London's area the event can be of local interest only. It is said that the bird used to breed in Windsor Park, which is beyond our radius; and there is no haunt in the vicinity of London from which wandering individuals might possibly come. If the Raven is ever observed in town nowadays the probability is that it has escaped from captivity.

One must go far afield nowadays to study the habits of the Raven in a wild state. Persecution has done its work only too well and banished the bird from most inland districts. Apart from this there is nothing which might have prevented the Raven from being one of London's birds to-day. The Carrion Crow still lives amongst us, 


\section{THE BIRD-LIFE OF LONDON}

the Rook is quite familiar, and the Jackdaw rears its young scarcely a stone's-throw from some of our busiest thoroughfares. The Raven is a solitary bird, seldom more than a pair being seen together; more frequently it is met with quite alone, but occasionally a party assembles in some spot where food chances to be exceptionally abundant. There are few more prying birds; it roams its haunts in all directions in quest of food, and its guttural cry of pruck-pruck heard before dawn and after dusk tells that it is abroad early and late in the quest. A pair of Ravens often frequent one particular district for time out of mind, driving off all intruders, and even their own young. The food of the Raven is varied to an astonishing degree. The bird will eat anything and everything, live birds and animals equally with carrion of all sorts, eggs, grain, acorns, marine creatures, fish, and so forth. Its flight is steady and powerful, performed by regular and deliberate wing-beats, and, in the pairing season especially, the bird often indulges in various aerial gambols. The breeding season of the Raven begins with March, the eggs being laid during that and the following month, according to circumstances. The huge nest used formerly to be very often built in a tree, but at the present time the majority of British Ravens resort to cliffs. The nest is made of sticks, mixed with turf and warmly lined with roots, wool, fur, and hair. Some nests are much larger than others, being the accumulation of years. The average clutch of eggs is five. They vary from bluish green to olive-brown in ground colour, spotted, splashed, and freckled with various shades of olive and grey. Occasionally a few very dark brownish specks are seen. The old birds are wary and watchful enough at the nest, and ever ready to beat off any but human intruders.

The adult Raven is entirely black, glossed with blue 200 


\section{THE RAVEN}

and purple, and the feathers on the throat are elongated into hackles. Bill black; tarsi and toes black; irides brown. Length 24 inches. The nestling lacks the metallic sheen so characteristic of the male, and to a lesser extent of the female. 


\section{THE CARRION CROW \\ CORVUS CORONE}

Local names in surrounding counties :

Status in British Avifauna: A common and widely distributed resident, rarer in some parts of Scotland, and more so in Ireland. Its numbers are increased in autumn by arrivals from the Continent.

Radial Distribution within fifteen miles of St. PAUL's : The Carrion Crow, although nowhere common, is generally distributed over the Metropolitan area, and may frequently be observed in some of the more central districts, such as Hyde Park, St. James's Park, the Green Park, and Regent's Park. Doubtless it pays passing visits to many of the intervening squares and open spaces, where it is usually mistaken for the Rook. It has been known to breed in Battersea Park, and also occasionally visits that attractive spot, and at least a pair were nesting in the spring of 1905 in the gardens of Gray's Inn. It also nests in Hyde Park and Kensington Gardens. In the more rural suburbs it becomes commoner, and I have records from most of the open spaces in these parts of the London area, from Clapham, Peckham, Streatham, and Wimbledon in the south; from Cricklewood, Willesden, Kilburn, Highgate, Hampstead, Tottenham, and Walthamstow in the north; from Epping and Ilford in the cast ; and from Chiswick, Acton, Wormwood Scrubbs, and 'Twyford in the west. It is said to breed in the Wimbledon and Bushey districts, around Hanwell, Wembley, Harrow, Barnet, Waltham, Epping, Victoria Park and Wanstead, near Dartford, in the Crays, Croydon, Banstead and Epsom, as well as in various intervening localities.'

Like the Raven the Carrion Crow is comparatively a solitary bird, but occasionally it associates in flocks where food chances to be exceptionally abundant. It has also 202 


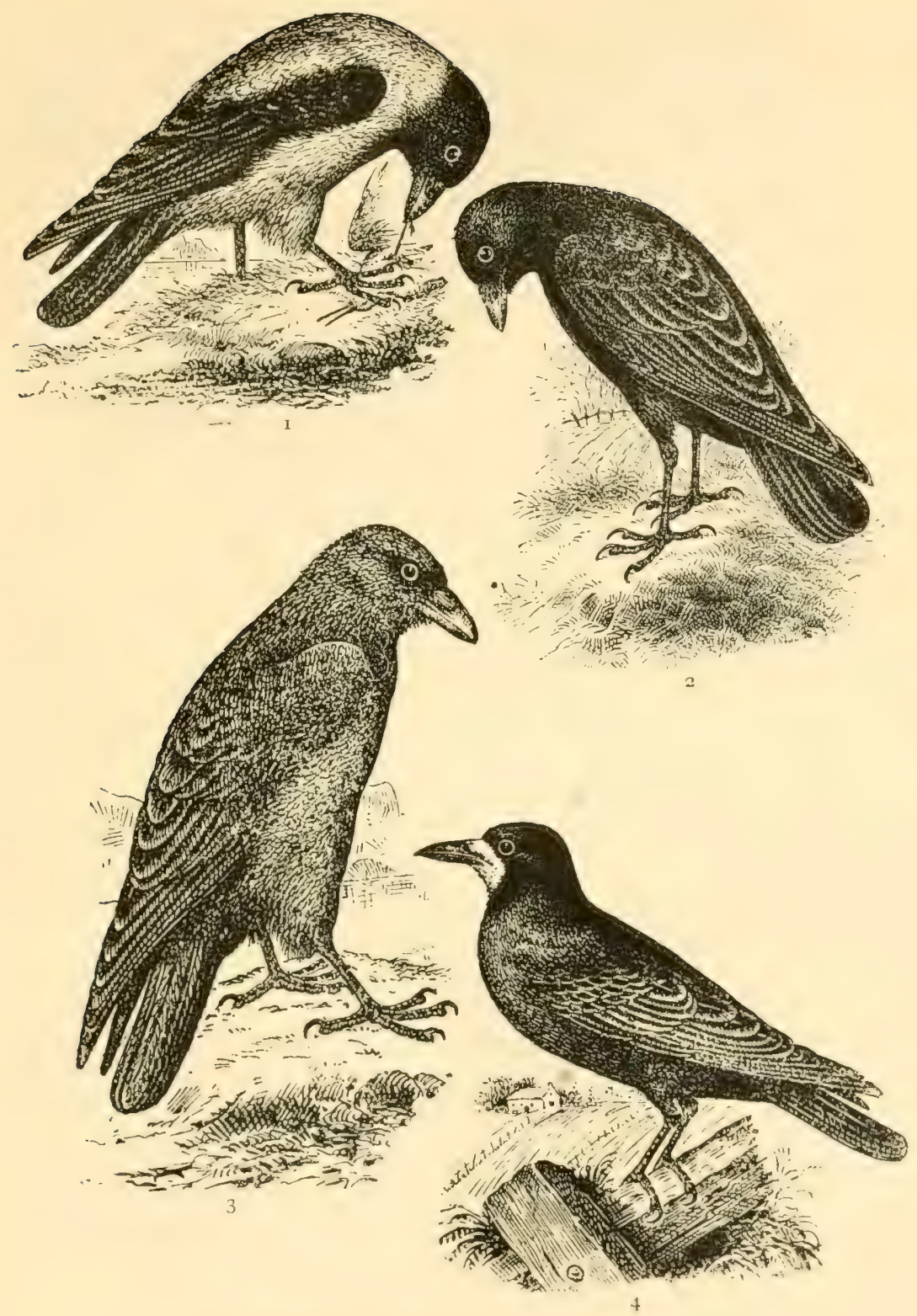

I. Hooded Crow. 2. Carrion Crow. 3. Raven. 4. Rook. 



\section{THE CARRION CROW}

been known to take up its abode with a colony of Rooks in Gray's Inn, and I have noticed similar instances in country districts. It is a most predaceous bird, preying upon anything it can capture or carry away, but otherwise its general movements and appearance are very similar to those of the better-known Rook. It is practically omnivorous in its diet, like the Raven, and its depredations on farms and in game-preserves bring down upon it only too well-merited retribution. By disposition shy and wary in the extreme, it is interesting to remark how these traits have become modified in the Crows that live in London. The note of this bird is quite sufficient to distinguish the species from the Rook. It is harsh and croaking, and very different in tone from the comparatively cheerful and peaceful caw of that bird. In the breeding season especially this note is modulated in various ways, especially when the bird is toying in the air with its mate or beating off a rival. The Carrion Crow may often be seen on the grass in the London parks, feeding either by itself or in the company of Rooks and Starlings and Ring-Doves. It walks about in the same sedate way as the Rook, feeds like that species, from which it may readily be distinguished by the green rather than purple sheen on its plumage, and by its completely feathered throat and forehead. The Carrion Crows breeding in the vicinity of London always make their nests in trees, but in many localities a ledge on a cliff is preferred, or is the only situation available. The nest is a bulky one, made outwardly of sticks and turf, lined with roots, wool, dry leaves, moss, fur, and hair, and occasionally feathers. The eggs, usually five, are green of various shades, blotched, clouded, spotted, and freckled with olive-brown and grey. The old birds are excessively wary during the nesting period, and as soon as the young can shift for themselves they are deserted by their parents.

The adult Carrion Crow is uniform black shot with 


\section{THE BIRD-LIFE OF LONDON}

purple and green, the feathers on the throat somewhat lanceolate in shape. Bill black; tarsi and toes black; irides brown. Length 19 inches. The female resembles the male in colour. The nestlings are similar to their parents, but there is little or no metallic sheen on the plumage. 


\section{THE HOODED CROW}

CORVUS CORNIX

Local names in surrounding counties : "Grey Crow," "Grey-back," "Hoody," "Dun Crow" (Essex).

Status in British Avifauna: A common and widely distributed resident in Scotland and Ireland, but a winter visitor only to England and Wales, instances of its breeding being most exceptional. Vast numbers visit our islands in autumn from the Continent.

Radial Distribution within fifteen miles of $\mathrm{S}_{\mathrm{T}}$. PAul's: A century ago the Hooded Crow is said to have been a very common bird near London. It is like a good many other species that once were common here but now only remain as traditions, such as the Kite, for instance, which in the days of long ago performed much of the scavengering of the streets. It is difficult to assign any reason for the comparative scarcity nowadays of the Hooded Crow within the Metropolitan area. Whether the species ever bred regularly near the Metropolis appears to be unknown. Certainly it never does nest now, and can only be regarded as a rare winter visitor, occurring at odd times and places, stragglers, apparently, from further north and east, where the bird is a commoner one at that season. It is said to be observed almost every winter on Wimbledon Common, and is also a regular if scarce wanderer to the Epping district. I have no records of this species from any of the urban parks or squares, although it is by no means improbable that the bird occasionally visits these spots.

'The traveller by rail on any of the north-bound trains from the Metropolis is sure to see the Hooded Crow here and there in the fields an hour or so's run from town, between the months of November and February. These birds are winter migrants, part of the vast hordes of Hooded Crows that cross the North Sea every autumn 


\section{THE BIRD-LIFE OF LONDON}

from the Continent, and the wonder is that they do not more frequently visit the fields and open spaces of Greater London. In Scotland the bird is a familiar one all the year round, and in many localities replaces the Carrion Crow. Its habits are much the same, only the bird is a much more gregarious one, in this respect resembling the Rook. It is equally omnivorous, seeking its food on the fields or the sea-shore, preying upon any living thing it can capture, any carrion it can find, or on any grain, potatoes, turnips, and so forth that come its way. It has the usual steady, prolonged flight of its kind, and in spring often indulges in aerial gambols. Its note is a harsh kra or krab, modulated at times into guttural chuckles. The Hooded Crow breeds rather late, the eggs being laid in April and May. Sometimes a tree is selected for the nest, but more frequently in our islands a ledge of rock on some cliff, or even the ground amongst long heather. Many pairs frequently breed in the same locality, although not exactly in colonies like Rooks. The big nest is made outwardly of sticks and turf, lined with wool, moss, hair, feathers, and fur. The eggs are usually five, green of various tints in ground colour, blotched and spotted with olive-brown and grey of several shades. The birds evince the usual Crow-like wariness during the breeding season, and after the young are reared social tendencies are again more pronounced.

The adult Hooded Crow has the head, wings, tail, lanceolate throat feathers, and upper breast black, shot with green and slightly with purple; the remainder of the plumage is grey. Bill black; tarsi and toes black; irides dark brown. Length 17-1 8 inches. The female is similar to the male in colour, as are the nestlings, but the latter lack all metallic lustre, and the feathers on the throat are less pointed. It has long been known that the Hooded Crow interbreeds with the Carrion Crow in certain localities where the two species occur. 206 


\section{THE ROOK}

\section{CORVUS FRUGILEGUS}

Local names in surrounding counties :

Status in British Avifauna : A common and widely distributed resident in England, Wales, and Ireland, becoming more local in Scotland, although extending its range there. Its numbers are increased in autumn by Continental migrants.

Radial Distribution within fifteen miles of $\mathrm{S}_{\mathrm{T}}$. PAUL's: There is a flourishing rookery within a thousand yards of St. Paul's Cathedral at the present time (1908), in the historic precincts of Gray's Inn ; whilst in many nther parts of the Metropolis the Rook is a familiar bird. A year or so ago quite a cluster of nests were built in the plane-trees at Gray's Inn overhanging Theobald's Road, but now the majority of the twenty-five nests are in the quieter portions of the enclosure. Other rookeries are studded about the more central parts of the Metropolitan area; one containing ten nests this spring is situated in Connaught Square, within a hundred yards or so of the Marble Arch. As we reach the more rural suburbs the colonies become more numerous and extensive, the bird being found breeding in every direction. It is quite a familiar species in all or most of the parks, although it has vanished as a breeding bird from certain localities, as, for instance, near Curzon Street, Mayfair. It also varies a good deal in numbers in the more central localities.

There are few birds that display a greater and more persistent attachment to their breeding stations than the Rook. Time works its vast changes in a district, and country becomes town, the old nest-trees gradually become surrounded by houses, yet the ancestral line of Rooks remain in their old homes as year by year the green fields and the feeding-grounds become more and more 


\section{THE BIRD-LIFE OF LONDON}

remote. The earliest settlers in some of these London rookeries found their food in the fields below the trees; their latest descendants have to fly miles to and fro for every morsel they eat or on which they nourish their broods. Not only so, but these town Rooks seem to be born with an inherited love for the Metropolis, and actually found new colonies wherever a suitable spot occurs. One of the most interesting examples of this fact known to me, and, indeed, one of the most interesting rookeries in London, is situated in the gardens between Calcott Road and Torbay Road, at Brondesbury. Upwards of a dozen nests occupy some low trees of an age about the same as the houses near them. The most amazing thing is that the Rooks should have settled in such a pent-up spot when plenty of better sites exist in the neighbourhood. Pages of interesting matter could be filled relating to the idiosyncrasies of the Rook, but we must now pass on to a brief review of its habits. The bird is by far the most social and gregarious of the British Crows, and lives in societies throughout the year For the most part the Rooks breeding in London leave the nest-trees as soon as the young can fly, only resorting to them for nesting purposes, and passing the remainder of the year on the fields and open spaces, roosting in certain spots regularly. The Rook flies powerfully with a measured beat of wing, but sometimes performs various aerial evolutions, notably one called "shooting," or descending quickly from a great height almost perpendicularly to the ground or trees below. Country people say this portends wind. The note of the Rook is too well known to require description here, the familiar caw being by no means an unpleasing sound. The food of this bird consists chiefly of worms, grubs, grain, acorns, and any carrion that may chance to fall in the bird's way. It is a bird of great use to the farmer and gardener, and deserves every encouragement from man. The Rook 208 


\section{THE ROOK}

is an early breeder, its eggs being laid in March or April. By the end of February the big nests are being repaired and others are being made. Yearly the same trees and the same nests are used, so that in some cases the latter are very bulky, being added to each season. They are made of sticks, cemented with mud and turf, and lined with moss, wool, dry leaves, straws, and sometimes a few feathers; the cavity is rather flat, but the lining smooth, and the whole structure is very substantial. I have often stood on a Rook's nest in perfect safety. The three to five eggs range from pale blue through various shades of green, blotched, spotted, and clouded with olive-brown and grey. The bustle and din of a rookery whilst nesting is in progress is too well known to need detailed description. Both parents incubate, and one brings food to the other whilst doing so. When the young are hatched they are fed assiduously by both parents, and it is now that the Rooks in many London rookeries must have a hard time of it, flying many miles over the houses and streets to grass-lands and other places in quest of food. As soon as the young Rooks leave the nest they resort to the fields and parks with the old birds, and during summer and autumn often wander far out in to the country to feed and to roost.

The adult Rook is entirely black, with a metallic sheen of purple, specially on the upper parts; the throat and space round the base of the bill is bare of feathers and covered with a grey, warty skin. Bill black; tarsi and toes black; irides brown. Length I7 inches. The nestling is dull black, with little or no metallic sheen, and the face and throat are covered with feathers. This bareness is gradually assumed, and usually completed after the autumn moult, but is sometimes partially deferred until the following spring. Young Rooks may be distinguished from Carrion Crows by the concealed grey bases to the body feathers, those of the latter being white. 


\section{THE JACKDA W \\ CORVUS MONEDULA}

Local names in surrounding counties:

Status in British Avifauna: A common and widely distributed resident, its numbers increased in autumn by foreign arrivals.

Radial Distribution within fifteen miles of Str. PAUL's: The Jackdaw is another tolerably familiar bird within the more central portions of the Metropolitan area, becoming more numerous and widely dispersed, of course, in the outlying and rural districts. The bird breeds in Hyde Park and Kensington Gardens ; may be frequently seen in St. James's Park, the Green Park, and in some of the more central squares, the Inns, and the Temple Gardens. It visits Battersea Park, Clapham Common, Peckham Rye, Regent's Park, and other similar open spaces, and probably breeds in all suitable spots from the six-mile radius to the most outermost limits. It is found breeding in many places where old timber furnishes the requisite nesting-holes, but also resorts to buildings; Epping and Richmond Park are good examples of the former, the towers of various churches and holes and chimneys in large houses of the latter. Like the Rook the Jackdaw varies in numbers a good deal in the more central districts, where the two species usually consort with each other. Just beyond our limits Windsor Castle and Eton College are famous resorts of the Jackdaw; as is Harrow within them.

The Jackdaw is another eminently gregarious species, living in colonies like the Rook, although in some cases conditions are such that it can only breed in more or less scattered pairs, especially in many parts of London where suitable sites are few. Its habits are very similar to those of its congeners. The bird resorts to fields and open spaces 210 
to feed, mingling freely with Rooks, Starlings, and RingDoves. It is wary enough in some districts, but in London especially may often be closely approached and watched. Its flight, however, is not so powerful as that of its larger allies, or perhaps it would be more correct to say it is performed by more rapid wing-beats, and is not so deliberate. The birds often wheel and circle in the air in a noisy crowd, especially before retiring to rest. The note of this species is a cackling cry, which, although harsh, is by no means unpleasing, and certainly the most musical of any of the British Crows. This note is subject to much modification, especially in spring, and when a flock unites in chorus the effect is impressive. The food of the Jackdaw consists of worms, grubs, insects, grain, fruit, acorns, beech-mast and even carrion, whilst in London and other cities the bird picks up scraps of bread and other trifles. The Jackdaw pairs for life, and uses the same nesting-place year after year. It is rather late to breed, commencing in April, and eggs may be found through that and the following month. It will make its nest in almost any hole or crevice, but in London holes in trees and buildings, church towers, amongst stone carving, and in chimneys are the usual places. The nest varies much in size, some structures being vast heaps of sticks when situated in spots that allow of repeated addition. If a small hole is used but little nest is made. The usual materials are sticks, and the cavity is lined with dry grass, moss, straws, and leaves, finally lined with fur, wool, and feathers. Usually five eggs are laid, ranging from pale blue to bluish green in ground colour, spotted and blotched with dark brown, olive-brown, and grey. They are much less heavily spotted and generally paler than those of the Rook or the Crow. But one brood is reared, and as soon as the young can fly they resort with their parents to the pastures, joining into flocks for the remainder of the year, although it should be remarked 


\section{THE BIRD-LIFE OF LONDON}

that odd birds may always be met with in the Metropolis.

The adult Jackdaw has the crown glossy black, the nape, sides of the head, and neck grey, the remainder of the upper parts black shot with violet and green; the under parts are lustreless black. Bill black; tarsi and toes black; irides greyish white. Length $\mathrm{I} 3$ inches. 'The female resembles the male in colour and the nestling is nearly uniform black, with no gloss, and no grey on the neck. 


\section{THE MAGPIE}

PICA CAUDATA

LOCAL names in surrounding counties :

Status in British Avifauna: A common and widely distributed resident in all woodland localities, but decreasing in many places owing to persecution.

Radial Distribution within fifteen miles of $\mathrm{S}_{\text {t. }}$ PaUl's: Although the Magpie has greatly decreased in numbers, it is still sparingly distributed over the more rural portions of the Metropolitan area as a breeding species, and occasionally wanders to the central districts. I have records of it from St. James's Park (where it breeds regularly), the Green Park (where it is nesting this spring, I909), Kensington Gardens, Hyde Park, Battersea Park, Peckham Rye, Clapham Common, Dulwich, Tooting, Willesden, Hampstead, Highgate, and Greenwich. If we take the above exceptions and that of the Wanstead district, the Magpie does not appear to nest anywhere else within the eight-mile radius. Beyond that limit the bird breeds, or very recently did so, in the districts of Wembley, Osterley, Hendon, Brockley Hill, Pinner, Ruislip, Southall, Bushey, Kingston, Epsom, Banstead, Croydon, Down, the Kentish Crays, Dartford, Epping, Waltham, and Barnet. During the non-breeding season odd Magpies frequently wander into the more central areas. In the winter of I903-4 I saw three Magpies in Kilburn, and I have on several occasions in spring met with pairs of them at Neasden. I have also seen the Magpie in what was formerly the show-grounds at Park Royal, as well as at Twyford, Chiswick, and Ealing.

There is no brighter or more effective bird-ornament to the woodlands and fields than the Magpie, and its presence should be encouraged in every suitable part of suburban London. With proper care the bird could 


\section{THE BIRD-LIFE OF LONDON}

possibly be established in all the big parks, where its strongly contrasted plumage and interesting ways could not fail to prove an increased attraction. For the most part the Magpie is a somewhat solitary bird, seldom more than a pair being seen in company, and as likely as not odd individuals. But there are times when more social tendencies are displayed. In spring and autumn small parties assemble occasionally, and in winter especially certain roosting-places are common to numbers. The Magpie seeks most of its food on the ground; otherwise it loves the trees, and may often be seen-a fluttering mixture of black and white-passing from one isolated tree to another, usually flying up into the branches in preference to descending into them. It is shy and wary at most times, but in the breeding season often displays more trustfulness. Its food chiefly consists of worms, insects, and grubs, fruit, acorns, beech-mast, and any carrion it may meet with. It is also an inveterate eggstealer, despoiling many nests, and will frequently carry off a young chick. Its note is a harsh chatter, heard most frequently at nightfall, and in the breeding season modulated in a variety of ways. The Magpie pairs for life, and yearly frequents the same nest, or builds another in the vicinity. This is usually made in a tree or lofty hedge, but sometimes an isolated bush is selected; and very often a site is chosen quite close to a house. It is a massive, well-built structure formed outwardly of sticks -thorns by preference-cemented together with large quantities of clay or mud, which material forms the inner cup. At this stage an intricate roof of sticks is added, a passage through them being left on one side near the rim ; and finally a thick lining of roots is added. The eggs, from six to nine in number, range from cream to bluish green, densely blotched and freckled over most of the surface with olive-brown, and occasionally streaked with darker brown. During incubation the sitting bird slips 214 


\section{THE MAGPIE}

off very quietly, but when the young are hatched the old Magpies are often very demonstrative. The brood and their parents remain in company for some time. The eggs are laid in March and April.

The adult Magpie has the head, neck, back, and breast black shot with green and copper; the lower back and rump are greyish white; the wings are black shot with green, each quill marked with white on the inner web, and the scapulars are entirely white, as are the shoulders; the under parts below the breast are white; the tailcoverts and the long, graduated, fan-like tail are black, the latter on the upper surface richly loricated with metallic bronze, green, and purple. Bill black; tarsi and toes black; irides brown. Length 16 inches. The nestling resembles its parents, but the colours are not quite so brilliant nor the plumage so loricated. 


\section{THE JAY \\ GARRULUS GLANDARIUS}

LOCAL names in surrounding counties: "Jay-bird" (Essex).

Status in British Avifauna: Still a fairly common and widely distributed resident in most woodland districts, but becoming more local and rarer in Scotland and Ireland. Its numbers are increased in autumn by arrivals from Continental areas.

Radial Distribution within fifteen miles of St. PAUL's: The Jay is another gradually decreasing species, yet still sparingly distributed over the Metropolitan area. I have no records of this bird from the central districts, from none of the parks and open spaces within the fourmiles radius. It is recorded as a breeding species from Dulwich and Norwood, Richmond and Wimbledon; to which in Middlesex may be added Osterley, Wembley, Harrow, Pinner, Ruislip Woods, Mill Hill, Stanmore, Kingsbury, Enfield, and Elstree ; in Essex may be given Waltham and Epping; in Kent, Dartford, the Crays, and Beckenham. To the Surrey localities I can also add the Croydon, Banstead, Epsom, and Esher areas. In autumn the Jay frequently wanders far from its usual haunts. I have seen it near Tooting Bec Common, to which it was doubtless attracted by an unusually large crop of acorns; whilst I have met with it occasionally at Neasden, stragglers probably from Wembley or Hendon. It also haunts the grounds at Muswell Hill; and is frequently seen near Rainham and Dagenham.

The Jay, another of our prettiest birds, should also be protected and encouraged in all parts of the London area ; indeed, efforts should be made to introduce this beautiful species into the large parks which contain suitable cover. There is nothing to prevent it becoming a denizen 2 I6 


\section{THE JAY}

of these, where its handsome plumage would prove an additional charm. The Jay is the most arboreal of the British Crows, and delights in woods and plantations where there is plenty of undergrowth. A good belt of thicket is absolutely essential to its needs. It is a most shy and seclusion-loving species, a brief glimpse of its particoloured plumage or its harsh scream of rark as it hurries off amongst the green branches usually being all that is seen or heard of it. It is the least social of the Crows, seldom more than a pair being seen in company, save in summer, when the broods and their parents keep together for some little time after the former have left the nest. It obtains most of its food upon the ground, although it is seldow seen there. This chiefly consists of worms, grubs, insects, fruit, grain, peas, acorns, beech-mast and even small birds, chicks, and carrion. The bird is partial to eggs, and robs many nests. A poisoned egg is one of the most fatal lures for this species. The flight of the Jay is singularly drooping, the wing-beats rapid, and sometimes the bird descends very rapidly from a great height almost perpendicularly like a plummet into the cover below. Its note is an oft-repeated rark-rark, and is heard most frequently in early spring and towards evening, but during the breeding season the bird is remarkably silent. It probably pairs for life, and its eggs are laid in April and May. The nest, placed at no great height from the ground in a tall evergreen or other bush, or in some sapling amongst the dense underwood, is a cup-shaped structure formed externally of twigs and a little mud, and copiously lined with roots. The five to seven eggs vary from greyish green to bluish green, mottled and freckled all over with olive-brown, and in some cases sparingly scratched with dark brown. The young are fed and tended for some time after leaving the nest, and the woodlands can offer few prettier sights than a troop of these restless birds. 


\section{THE BIRD-LIFE OF LONDON}

The adult Jay has the prevailing colour of its plumage vinous brown, palest below, except the lower back and upper tail-coverts, which are white; the bushy crest is greyish brown streaked with brownish black; the wings are black margined with white, and the secondaries have a white patch at the base, the innermost one chestnut tipped with black; the wing-coverts are black on the inner web, barred on the outer web with black, white, and cobalt-blue in succession; the tail is black, faintly barred on the basal half with blue, the under tail-coverts white; from the gape a broad stripe of black extends down each side of the throat, which is greyish white. Bill black; tarsi and toes brown; irides pale blue. Length 13 inches. The sexes are alike in colour, and the nestling resembles its parents. 


\section{THE SW ALLOW \\ HIRUNDO RUSTICA}

Local names in surrounding counties :

Status in British Avifauna: A common and widely distributed summer visitor, of almost universal occurrence.

Radial Distribution within fifteen miles of $\mathrm{S}_{\mathrm{T}}$. Paul's: The Swallow is a common summer visitor to all suitable parts of the Metropolitan area. There can be no doubt that years ago the bird nested very much nearer to St. Paul's than it does now. There are spots to which it yearly resorts to nest within the four-mile radius, but these are few. It is recorded as having bred in I 884 on St. Luke's Church at Battersea, and undoubtedly does so in the Dulwich and Hampstead districts. It is more commonly dispersed in the outlying suburbs, and breeds from a radius which includes Tooting, Streatham, Barnes, Chiswick, Acton, Willesden, Highgate, Hornsey, Wood Green, Leyton, Stratford, Wanstead, Greenwich, and Sydenham to the extreme boundaries of the Metropolis. During spring and autumn the Swallow often visits the more central localities. I have seen it flying over the City, and it frequently resorts to the urban parks. I have watched it hawking for insects above the Serpentine, the lake in St. James's Park, the ornamental water in Regent's Park, and the Thames between Battersea and Westminster. Years ago it might often be seen flitting above the filtering-beds near Battersea Park Station, and may be now.

If the atmosphere of inner London could be made purer and better adapted for insect life there can be little doubt that the Swallow would return to many longdeserted haunts and rear its young within them. All other conditions are suitable, for there are many towns in England where the Swallow may be seen threading 


\section{THE BIRD-LIFE OF LONDON}

the streets all day long, and in its winter home in Africa it is a common dweller in the towns. The Swallow arrives in the London area towards the middle of April, and leaves it again in late September or early October, although it is not very unusual to see odd birds passing over even in November. I have seen Swallows at Richmond as late as the middle of that month. The bird spends most of its waking moments in the air, in tireless quest of food, flying hither and thither on rapid wing, now in the higher atmosphere, anon just above the ground, wherever its insect prey chances to be most abundant. It is social during summer, and in autumn, as the time of its departure draws near, it assembles in large companies, which often roost amongst rushes or in osier-beds. Its ordinary call-note is a shrill whet, often repeated as a twitter, and throughout its stay the male, in the breeding season especially, has a delightfully pleasing song, uttered not only on the wing, when it sounds particularly joyous, but whilst the bird is at rest on some building, bare branch, or telegraph wire. In autumn the young males make their first attempt at song. The food of the Swallow is entirely composed of insects. Some of these are picked up on the ground, others secured whilst they are resting on the surface of water. The Swallow pairs for life, and annually returns to its accustomed nestingplace. The eggs for the first broods are laid in May, for the second in July. In the London district the nest is usually made in a shed or out-building of some kind, in a church tower or a disused chimney, or some convenient ledge, beam, or projection. It is a shallow, saucer-shaped structure, made of pellets of mud mixed with bits of straw, and lined with dry grass and feathers. The five or six eggs are pure white, freckled, spotted, and blotched with various shades of coffee-brown and violet-grey. The young are tended for some time after leaving the nest, and are fed whilst in the air or whilst sitting on some 220 


\section{THE SWALLOW}

building or tree. The Swallow becomes increasingly interesting in autumn, when its gregarious instincts are most developed. Many pass the Metropolis on migration.

The adult Swallow, readily distinguished from the Swift and the two species of British Martins by its uniform steel-blue upper parts and long, slender outermost tailfeathers, has the forehead and throat chestnut, the upper parts and a broad pectoral band blue shot with purple; the wings and tail are black shot with green, the latter long and acutely forked; across the tail is a row of circular white spots; the under parts are white slightly suffused with buff. Bill black; tarsi and toes black; irides brown. Length $8 \frac{\pi}{2}$ inches (of which the long slender outermost tail-feathers measure nearly 5 inches). The nestling has the chestnut paler, the white spots on the tail pale chestnut, and the outermost feathers are much shorter. 


\section{THE HOUSE MARTIN}

CHELIDON URBICA

LOCAL names in surrounding counties:

Status in British Avifauna: A common and widely distributed summer visitor of almost universal occurrence.

Radial Distribution within fifteen miles of $\mathrm{Sr}$. Paul's: 'The House Martin seems ever to have shown a partiality for the Metropolis. In Gilbert White's time the bird nested in the Borough, in Fleet Street, and in the Strand. It has deserted these places now, but within recent years nests have been recorded in St. James's Street, Porchester Place, and Upper Seymour Street, the firstnamed being well inside the two-mile radius. There are many spots in the central portions of the Metropolitan area where the House Martin breeds every year, and it is generally dispersed over the more rural suburbs, commonest, of course, in the outlying districts. Small colonies of this Martin may be seen in some of our busy suburban thoroughfares; at Harlesden, for instance, near the High Street, and on some tall buildings opposite the police station. There are also many scattered nests in the quieter by-streets, and the numbers would unquestionably increase were it not for the molestation of the Sparrows, and the antipathy of householders, who in many cases strip down the mud-built home above their windows. The House Martin may also occasionally be seen hawking over the Thames between bridges, and visits the lakes in the urban parks, the canals, and so forth.

The House Martin returns to its summer haunts in the south of England about the middle of April, and returns to its winter home in September and October. With regard to its appearance in Greater London, I have invariably remarked that in many localities the birds are not seen at their actual nesting-sites for weeks after they 222 


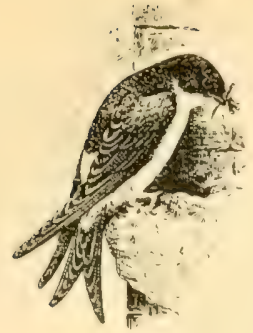

I

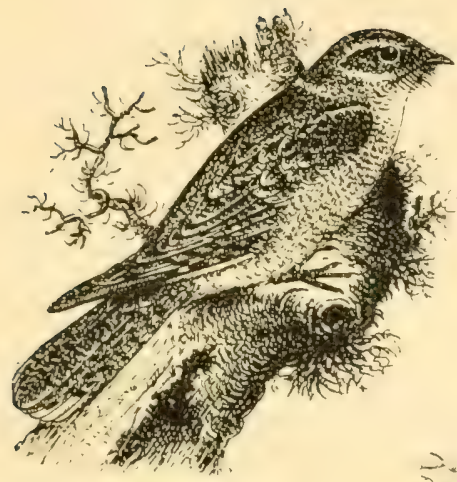

3
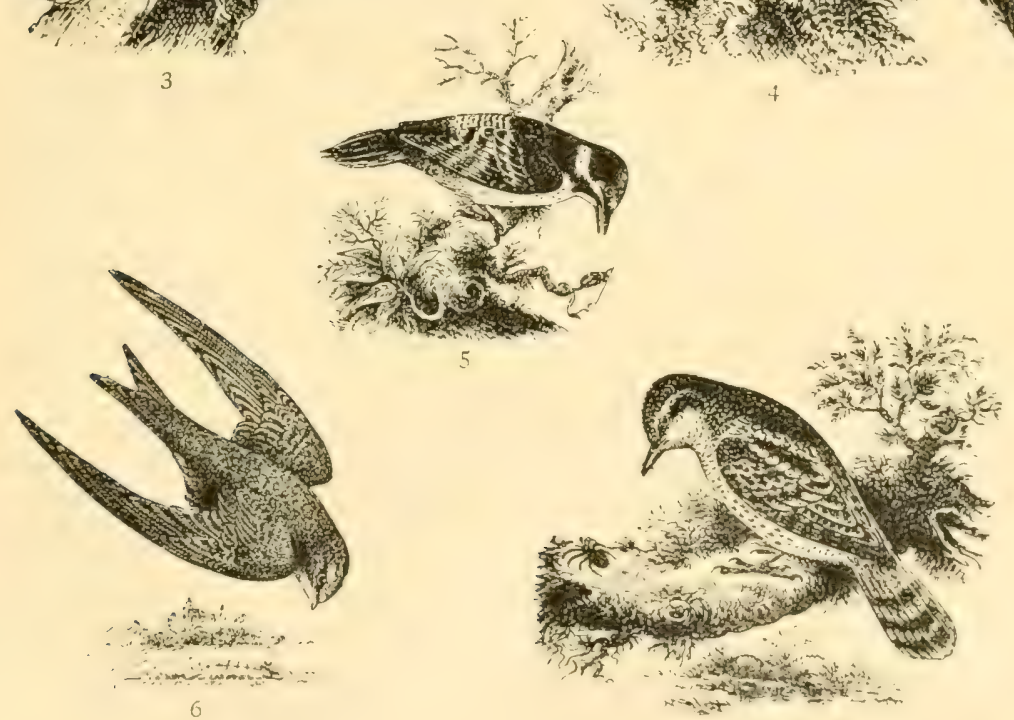

7

I. House Martin. 2. Sand Martin. 3. Red-necked Nightjar.

4. Great Spotted Woodpecker. 5. Lesser Spotted Woodpecker. 6. Common Swift. 7. Wryneck. 



\section{THE HOUSE MARTIN}

reach this country. 'This is a very interesting and curious fact, which I have not seen recorded in any account of the habits of the House Martin. The birds apparently only resort to their nests in many London thoroughfares just at the time they are going to use them. This species closely resembles the Swallow in many of its habits. It passes the same aerial existence, flitting to and fro for the livelong day in quest of food. Occasionally it may be seen sitting on some roof, bare branch, or telegraph wire, and sometimes alights upon the roads. When at rest in these places its movements are awkward and assisted by the half-open wings, for its legs are too short to allow it to walk or hop in any comfort. Its food is composed of insects, chiefly caught on the wing. It has a delightful little song, uttered in a low, warbling strain, but is not heard so frequently as the Swallow; its call-note is a shrill, spluttering cry. Like the Swallow, the House Martin returns unerringly every year to its old haunts, and the same nests are occupied season after season, when left untenanted by Sparrows. These birds harras the Martins incessantly and often cause them to desert a breeding-place altogether. This Martin pairs for life, and generally rears two broods each season, the eggs for the first being laid in May, for the second in July. In London the nest is usually made under eaves, in the corner of windows, or below plinths and carved stone-work; but in many localities it is attached to cliffs, bridges and so forth. It is shaped something like half a cone, sometimes more globular, and is made externally of little pellets of mud, which the birds pick up from the roads or any convenient place. I have seen numbers of Martins gathering mud after a water-cart had passed along a suburban road. A small hole at the top admits the parents. This shell is lined with dry grass and feathers. The four or five eggs are white and spotless. After the young are reared the House Martin becomes still 


\section{THE BIRD-LIFE OF LONDON}

more gregarious. Numbers of nests may be built side by side, but the colonies are never in proportion to the vast gatherings that assemble in autumn before the migration south. Their ways at this season are full of interest, their daily flights and their evening gatherings at osier- and reed-beds, where they roost, being very characteristic.

The adult House Martin has the general colour of the upper part glossy steel-blue; the rump and some of the upper tail-coverts are white; the wings and tail are brownish black, the latter considerably forked; the under parts are white. Bill black; tarsi and toes covered with tiny white plumes; irides brown. Length about $5 \frac{x}{4}$ inches. The nestling is brownish black above, without gloss; the rump is white, as are the under parts, but the wings are margined with white, the secondaries tipped with the same. 


\title{
THE SAND MARTIN
}

\author{
COTYLE RIPARIA
}

Local names in surrounding counties :

Status in British Avifauna: A common yet somewhat local summer visitor of almost universal distribution.

Radial Distribution within fifteen miles of $S_{T}$. Paul's: Gilbert White tells us that in his time the Sand Martin resorted to the dirty pools of Whitechapel, and he thought that they nested in scaffold holes in some buildings near by. The bird has long deserted the city precincts, although it is an occasional visitor to the Thames near Westminster and Lambeth, to the sheets of water in St. James's Park, Hyde Park, Regent's Park, Battersea Park, the tank in the Stadium, and so forth. The Sand Martin is recorded as breeding at Hampstead and Pinner. It certainly does so near Wormwood Scrubbs. There are many breeding colonies along the banks of the Thames in the outlying portions of the Metropolitan area; another at Coombe Warren; others wherever suitable conditions are presented in the Surrey and Kentish suburbs; whilst the same remarks apply to Essex. In autumn especially large gatherings of the Sand Martin congregate over such large sheets of water as the Welsh Harp, Kingsbury Reservoir, Elstree, Hampstead Ponds, the lake in Wimbledon Park, the Penn Ponds in Richmond Park, and many of the reaches of the Thames, notably near Hampton Court. 'These birds in many instances appear to roost in osier-and reed-beds, and often consort with Swallows and House Martins.

The Sand Martin is the first of the "Swallows" to reach us in spring, often being seen in London towards the end of March, and in greater numbers early in April. Its uniform dull plumage will readily distinguish it from its allies. The general actions of this species are very 


\section{THE BIRD-LIFE OF LONDON}

similar to those of the preceding Swallows, but the flight is not so powerful, more hesitating and fluttering. It is rarely heard to sing, and its call is a harsh, twittering cry. It is always interesting to remark how readily birds avail themselves of any little advantage. For many years I knew that the Sand Martin frequented the brickfields between Wood Lane and the waste ground which the late FrancoBritish Exhibition occupied. But these fields are done away with now, and are being rapidly filled in. The large sheet of water in the Stadium at the exhibition, however, provided a haunt for several pairs of Sand Martins, and the birds frequented this place all through the Olympic Games. They nest in other brickfields to the west of the exhibition site. The Sand Martin feeds exclusively on insects. It is just as gregarious and social as its allies, breeds in colonies, and returns year by year to its old nesting-places. It also frequently rears two broods in the summer, laying in May and July. Unlike the House Martin, however, it makes its nest in a hole in a bank, boring a tunnel into the soft gravel or clay for several feet, and making a slight nest at the end of it, of dry grass and straws, lined with feathers. The four or five eggs are spotless white. A colony of Sand Martins is very interesting. Birds may be seen flying to and fro before the face of the bank or cliff in which the nest-holes are bored; others at intervals enter the tunnels, or leave them to join the flitting throng outside. When the young are reared the birds assemble into large flocks, which appear to have certain rendezvous, water of some kind, and here the scene is most animated. They are preparing for departure; each day the crowds increase, and roost at night in some reed- or osier-bed. The migration south begins in September, and continues into October. Odd birds even occur near London during November. I have seen this Martin as late as the middle of that month at Richmond.

226 


\section{THE SAND MARTIN}

The adult Sand Martin has the general colour of the upper parts mouse-brown, with a slight purple sheen; the wings and tail are blackish brown, the latter slightly forked; there is a broad band of brown across the breast, and the remainder of the under parts is white; there is a tiny bunch of feathers at the back of the tarsus. Bill black; tarsi and toes dark brown; irides brown. Length about $4 \frac{3}{4}$ inches. The nestling closely resembles its parents in general coloration, but most of the feathers of the upper parts are margined with pale buff, and the white under surface is suffused with the same. 


\section{THE SWIFT}

CRPSELUS APUS

Local names in surrounding counties: "Shriek Owl," "Deviling," “Tommy Devil” (Essex).

Status in British Avifauna: A common and widely distributed summer visitor.

Radial Distribution within fifteen miles of St. Paul's: The Swift is another bird that formerly bred in the very heart of the city, on the Tower, and in the towers of some of the churches in the Borough. I have seen the Swift in such central spots as Battersea, Kensington, Lord's cricket ground, and Regent's Park; further afield at Clapham, Dulwich, Peckham, Greenwich, and Victoria Park, but do not know whether it breeds in any of them. Of the more rural suburbs, however, in which it regularly does so, I may mention Willesden (in the tower of the old parish church), Harlesden, Kilburn, Putney, Wimbledon, Tooting, Streatham, Sydenham, Eltham, Woolwich, Wanstead, Epping, Enfield, Hendon, and Wembley. It is also a regular visitor to the Harrow, Hanwell, Southall, Hounslow, Richmond, Kingston, Merton, and Banstead districts. In fact, there are few if any of the more rural suburbs that the Swift does not visit occasionally, if it does not regularly nest in them, and as we get into the outlying areas its presence calls for no special record. Taking into consideration the facts of its Metropolitan distribution the bird must migrate regularly over the very central parts of London. I have seen small parties obviously on passage over Paddington, St. John's Wood, and above the Stadium.

Although popularly classed as one of the Swallows, the Swift is but remotely related to them, its nearest allies being, perhaps, the Humming Birds of the New World. The Swift is one of the latest summer migrants, 228 


\section{THE SWIFT}

not reaching its London haunts before the beginning of May, or in early seasons the last few days of April. Its stay is brief, and it leaves again during the first ten days or so of August. I saw a single Swift, however, at Twickenham on August 23, 1905-a remarkably late record; whilst on the same date two years later many were passing down the Brent Valley near Stonebridge (close to Wembley Park) in company with Martins. I may add that this valley is a marked migration route for Swallows and Martins, flocks often passing in late autumn in countless numbers for days in succession. 'The Swift is one of the most aerial of birds; it is rarely seen to alight anywhere, beyond dashing into its nesting-place and out again. It is easily recognised by its dark plumage, long, scythe-shaped wings, and short, forked tail. It has no song, but its shrill, screaming note, often uttered with much persistency in early June and shortly before departure in August, is very characteristic. The bird becomes particularly active and noisy towards evening, careering about the air often at a great height, or in dull, cloudy weather nearer to the earth. It feeds exclusively on insects. Throughout its stay it is more or less gregarious, breeding in colonies of varying size, and in autumn especially assembles into flocks to migrate. The Swift pairs for life, and returns to breed in one particular spot. Its eggs are laid towards the end of May or early in June. Its favourite nesting-place is a hole in a building, beneath the eaves, or in a church tower. The simple nest consists merely of a few straws or bits of dry grass, lined with feathers, and often bound together with the bird's viscid saliva, accidentally accumulated as the old birds arrange the scanty materials. The eggs are two, as a rule, but in rare cases three or four are found. They are much elongated, white and spotless. The young are fed occasionally for some time after they leave the nest, and only one brood is reared during the summer. 


\section{THE BIRD-LIFE OF LONDON}

The adult Swift has the general colour of the plumage blackish brown, merging into greyish white on the throat, and the upper parts possess a bronze-like sheen. The tail has only ten feathers. Bill black; tarsi covered with dark brown plumes; toes dark brown; irides brown. Length about $7 \frac{\mathrm{x}}{2}$ inches. The nestling has the white patch on the throat purer in tint, and most of the feathers of the upper parts have greyish margins. 


\section{THE GREEN WOODPECKER}

\section{GEGINUS VIRIDIS}

Local names in surrounding counties: "Whetile," "Yaffle," "Rain Bird," "Heigh-ho" (Essex).

Status in British Avifauna: A locally dispersed resident in England, chiefly south of Yorkshire; almost unknown in Scotland and Ireland.

Radial Distribution within fifteen miles of $\mathrm{S}$ t. PaUl's: Haunts of the Green Woodpecker may still possibly be found at Highgate and Hampstead well within the five-mile radius, but elsewhere in a similar limit the bird can only be regarded as an occasional wanderer, if it occurs at all. I have no records of this Woodpecker from any of the large urban parks. Coming to the more rural suburbs, the bird is found in the Dulwich, Wimbledon, and Richmond districts; at Bushey, Hounslow, Twyford, Harrow, Wembley, Pinner, Ruislip, Stanmore, Brockley Hill, Mill Hill, Edgware, Barnet, Enfield, Waltham, Epping, Hornchurch, Dagenham, Dartford, the Crays, Croydon, Banstead, Epsom, and Bushey. Again, it may be remarked that these localities only indicate the general distribution of the Green Woodpecker; there are many intervening ones where the bird may be met with. It is, however, a somewhat local and thinly dispersed species. Slightly beyond our radius the bird is exceptionally numerous in Windsor Park, at Cookham, Farnham (where I have taken many nests), and in the vicinity of Ditton.

There still remain, it will be seen, many ideal haunts for the Green Woodpecker in Greater London. The grand old parks and grounds, containing so much magnificent timber, admirably meet this bird's requirements, and the only wonder is that it occurs in such comparatively small numbers. Its natural shyness and love of seclusion may be the predominating cause. It is for the most 


\section{THE BIRD-LIFE OF LONDON}

part a solitary bird, and although paired for life the sexes do not appear to keep very close company except during the breeding season. There are few warier species, and even when feeding it is watchful enough, and always endeavours to pursue its search on the side of the trunk or branch furthest away from an observer. If approached too closely it departs in a dipping flight to another tree, often uttering a shrill and loud $b i-b i-b i$ as it goes. This note, however, is chiefly heard during the breeding season. It by no means confines itself to the trunks and big limbs of trees, upon which much of its food is sought, but readily perches on the slender branches near the top. It may be observed to alight on some massive tree-trunk close to the ground, and then in a more or less zigzag course work its way up to the summit, creeping about the bark, supported by its stiff tail-feathers, and occasionally running out for some distance above or below the larger limbs, every now and then the lusty tapping of its stout bill being heard as it dislodges some lurking insect. Occasionally it may be flushed from the ground, to which it resorts in quest of ants and their larvæ. The food of this Woodpecker largely consists of insects, occasionally acorns and hazel-nuts, and I have repeatedly seen the bird eating haws. Its breeding season commences in April or early May, the nest being made in a hole of a tree, less frequently in a cliff. This hole is dug out by the old birds, the hard, powerful, chisel-shaped bill being admirably adapted for the purpose. Sometimes the wood is rotten or partly so, and then the work is easy; at others it is sound, involving much more labour. For a little way the hole is more or less horizontal, then it takes a downward turn for about a foot, and at the bottom, in an enlarged chamber, the eggs are laid on no other nest but the powdered wood or a few chips. An occupied nest is generally indicated by a number of these chips lying on the ground below. 'The eggs, from five to eight, are 232 


\section{THE GREEN WOODPECKER}

white and highly polished. But one brood is reared in the year.

The adult male Green Woodpecker has the general colour of the upper parts olive-green, merging into bright yellow on the rump; the lores, cheeks, and ear-coverts are black, the cheeks speckled with scarlet; the crown and nape are grey, marked with scarlet; the wings and tail are dark brown, the outer webs of the primaries barred with greyish white, the same webs of the secondaries olive-green with pale bars; the tail is also barred; the under parts are pale greyish green. Bill dark grey; tarsi and toes grey; irides greyish white. Length $\mathbf{3} 3$ inches. The female has no traces of scarlet on the cheeks. The nestling is barred above and below, there is no black on the lores and ear-coverts, and the black on the cheeks is spotted with brown in young females, with scarlet in young males. 


\section{THE GREAT SPOTTED WOODPECKER}

\section{PICUS MAFOR}

Local names in surrounding counties: "French Magpie" (Essex).

Status in British Avifauna: A widely distributed if local resident in the woodlands of England and Wales, becoming rarer north of Yorkshire. It is not known to breed in Scotland, and is absent from Ireland. Its numbers are increased to a certain extent in autumn by migrants.

Radial Distribution within fifteen miles of $\mathrm{S}$ t. PAUL's: This Woodpecker seems everywhere to be less common than the preceding, and in many localities where its larger ally is comparatively numerous this species is rare, or absent altogether. It is a resident in Epping Forest and Wanstead, but is very local, and the same may be said regarding the Wembley district. So far as I know these three localities probably represent the only nesting ones within the immediate vicinity of London. It is said to breed occasionally in Richmond Park, but competent observers remark upon its rarity in that place. I have few records from any of the more central parks, but the bird is certainly a casual visitor to Kensington Gardens. On the other hand, there are many districts in the rural suburbs which this species probably visits occasionally, and is overlooked. There are many woodlands in these localities, full of grand old timber, and quite secluded enough to offer it a congenial refuge. Beyond our radius Windsor Park, Ditton Park, Taplow, Eton, and Burnham may be mentioned as localities for this species.

The Great Spotted Woodpecker is perhaps more fre234 
quently seen in the tops of trees, and does not visit the ground so much as the Green Woodpecker; otherwise the habits of the two species have much in common. I ought to add that the bird is also more commonly seen in orchards and wooded private grounds than its larger ally, often taking up its residence in them for weeks, but invariably disappearing as the breeding season comes round. It is just as shy and secretive, just as solitary, and obtains its food in much the same way. It searches trunks and branches, usually commencing at the foot of a tree and working upwards in erratic course, ever and anon pausing to hammer away at the bark, supporting itself by its long and rigid tail. Like the Green Woodpecker it generally contrives to pursue this search on the further side of the timber, at intervals peering round the trunk or limb, just its head visible, and then disappearing again. Its tapping may be heard for a long distance through the silent woodlands, and sometimes the blows follow each other so rapidly that they sound as if the tree or branch were being torn asunder; this has been thought to be a signal between the sexes, as it becomes specially frequent during the breeding season. Its usual call-note is a shrill whit. The food of the Great Spotted Woodpecker consists of insects and larvæ, berries of various kinds, stone-fruits, nuts, and acorns. It breeds in May and June, apparently pairs for life, and frequently uses the same site year by year. The nest is a hole excavated in some tree-trunk or large branch, but sometimes one already made is utilised. It is the usual shaft, enlarged at the bottom, and here the eggs are deposited with no other provision. These are from five to eight; white, with a faint suffusion of yellow, and considerably polished. But one brood is reared each year. During winter this Woodpecker wanders about a good deal, and occasionally visits places where trees are small or absolutely wanting.

The adult male Great Spotted Woodpecker has the 


\section{THE BIRD-LIFE OF LONDON}

general colour of the upper parts bright black; the forehead is buff, the nape scarlet; the lores and ear-coverts are white, the cheeks black, the latter colour extending to the sides of the neck, whilst a black streak runs from the nape to the sides of the neck; the wings are barred with white, and the scapulars are white; the tail is black, the outermost feathers barred with white; the under parts are very pale buff, shading into scarlet on the abdomen and under tail-coverts. Bill black; tarsi and toes dark brown; irides crimson. Length $9^{\frac{x}{2}}$ inches. The female resembles the male in general coloration, but has no scarlet on the nape. The nestling has the scarlet on the under parts much less brilliant, and absent entirely from the nape, but has a scarlet crown and forehead, most developed in the young male. 


\section{THE LESSER SPOTTED WOODPECKER}

PICUS MINOR

Local names in surrounding counties :

Status in British Avifauna: A widely distributed resident in the wooded districts of England and Wales, becoming rarer north of Yorkshire, and absent from Scotland and Ireland.

Radial Distribution within fifteen miles of $\mathrm{S}_{\mathrm{T}}$. PAul's: This is by far the most plentiful and generally dispersed of the Woodpeckers in the Metropolitan area. I can give no records of it from any of the central districts, although it is quite possible that such a tiny species has been overlooked. The Lesser Spotted Woodpecker is fairly common in the Dulwich, Wimbledon, Richmond, Bushey, and Hanwell districts. Thence it may be found at Horsenden, Sudbury, Wembley, Brentford, Kew, Ealing, and Hampstead. It is also a local resident at Elstree, Harrow, Pinner, Ruislip, Stanmore, Kingsbury, Mill Hill, Barnet, Enfield, Waltham, Muswell Hill, Epping, Wanstead, and Dagenham. On the Kentish side of the river among the localities frequented may be mentioned Woolwich, Dartford, the Crays, Bromley, and Farnborough; whilst in Surrey, again, to complete our radius, we may add Croydon, Banstead, Sutton, Cheam, Merton, Esher, and Epsom. Beyond the radius, but within easy reach of the Metropolis, I may add that Eton, Windsor, Ditton, and Burnham are favourite resorts of this Woodpecker.

The Lesser Spotted Woodpecker is just as shy and retiring in its ways of life as its larger allies, and its small size renders it even more likely to escape notice. It frequents similar situations, but shows perhaps more 


\section{THE BIRD-LIFE OF LONDON}

partiality for smaller timber, for gardens and orchards. Like all its allies it may often be seen in isolated trees in fields and hedgerows. Its habits and actions resemble those of its kindred. It explores the crevices of the bark on trunk and branches, running hither and thither in a very fly-like way, pausing at intervals to tap the wood and dig out some lurking insect. It is just as active, has the same peculiar undulating flight, and like the preceding species is often observed in the tops of the trees. Its usual note is a shrill whit, and the bird has the same peculiar way of signalling to its mate, especially in the breeding season, by a series of rapid taps on the timber. It is just as solitary, too, but in winter it is sometimes seen in the company of 'Tits and Creepers, perhaps more from the accident of meeting than from any social inclination. Its food is chiefly composed of insects, especially larvæ of various kinds. It is a slightly earlier breeder, the eggs being laid towards the end of April and during May. Like its congeners it probably pairs for life, often returning to nest in the same spot. The nesthole in a tree is usually excavated by the birds themselves, but in rare instances one is selected ready made. It is of the usual character, dug out by both birds, from six to twelve inches in depth, slightly enlarged at the bottom. Here the female deposits on the bare wood and dust from five to eight glossy white eggs. Like most hole-building birds, this Woodpecker sits closely, and often allows itself to be taken rather than leave its eggs or young. As a rule but one brood is reared each season.

The Lesser Spotted Woodpecker so closely resembles its larger congener that a detailed description is unnecessary. The back and rump, however, are barred with white, and the white on the innermost secondaries is greater in extent; the ear-coverts are suffused with brown, and not separated by any black line from the white on the sides of the neck; whilst the flanks 238 


\section{THE LESSER SPOTTED WOODPECKER}

and the breast are streaked with brown. There is no scarlet on the under parts, this being confined to the crown of the adult male; in the female the crown is white. Length about $5 \frac{3}{4}$ inches. The nestling closely resembles the parents in general colour. 


\section{THE WRYNECK}

\section{ITNX TORQUILLA}

Local names in surrounding counties: "Snake-Bird," "Cuckoo's Mate" (Essex); "Pay-Pay" (Surrey).

Status in British Avifauna: A local summer visitor, commonest in the southern and eastern counties of England, rarer in the northern and western ones and in Wales and Scotland. It has been obtained once in Ireland, straying there on passage occasionally.

Radial Distribution within fifteen miles of $\mathrm{S}$ t. PAUL's: The Wryneck visits much more central districts than the Woodpeckers, and has been recorded from areas no more remote than Highgate, Hampstead, Kensington Gardens, Barnes, and Battersea Park. Its regular breeding haunts may be said to commence between the six-and seven-mile radius, which includes Sydenham, Tooting, Dulwich, Wimbledon, Dollis Hill, Hornsey, Plaistow, and Lewisham. Beyond this limit, in the more rural suburbs, the following localities (as well as various intervening ones) may be mentioned as haunts of the Wryneck : Richmond, Bushey, Kew Gardens, Chiswick, Brentford, Osterley, Hanwell, Ealing, Twyford, Sudbury, Wembley, Harrow, Kingsbury, Pinner, Ruislip, Mill Hill, Barnet, Enfield, Waltham, Epping, Wanstead, Romford, Dagenham, Rainham, Dartford, the Crays, Bromley, Croydon, Merton, Banstead, Epsom, Esher, and Kingston. The Wryneck, from the evidence available, appears to be rarer and more local in Essex than elsewhere.

This beautiful little bird reaches its London haunts towards the end of March. I have seen it in Richmond Park as early as the $23 \mathrm{rd}$ of that month. Although closely allied to the Woodpeckers, the Wryneck does not possess rigid tail-feathers; neither does it climb trees in the same $24^{\circ}$ 


\section{THE WRYNECK}

way as its kindred. It is also much more frequently seen in isolated trees, in gardens and orchards, and shows a decided preference for open yet well-timbered ground rather than woods. Its shrill, loud, far-sounding cry of beel-beel-beel soon proclaims its presence in spring; and although it is not so secretive as the Woodpeckers it is very apt to be overlooked. It is by no means sociable, and although probably paired for life the sexes do not keep very close company except during the breeding season. It obtains a good deal of its food from the timber, but never climbs about the trunks in quest of it, perching across the bark, and very often alighting in the slender branches. It often visits the ground, hopping like a Woodpecker, and frequents ant-hills to prey upon the insects and their larvæ. If disturbed it hurries away in undulating flight to the nearest trees. Many insects are also picked from the leaves and slender twigs; others are actually chased in the air. Although it lives almost exclusively on small insects and their larvæ, it is said occasionally to eat elderberries; and it never seems to bore into the bark or decayed wood in quest of food like its allies, although its bill is quite strong enough to do so. The Wryneck breeds in May and June, and by the end of the latter month it has ceased to call, and remains silent until its departure. Unlike the Woodpeckers, this bird does not excavate a nest-hole, but seeks one amongst the timber already made. This hole may be in a tree of some kind, or even in a dead stump. Sometimes it may be slightly enlarged or altered. At the bottom of this hole, on the powdered wood alone, the female lays from six to ten shining white eggs. The Wryneck rears but one brood in the season, but if the first eggs are removed others will be laid. The parent sits closely, allowing itself to be removed, when it often hisses and shams death, or contorts itself in the most ridiculous manner. The young are tended for some time after 


\section{THE BIRD-LIFE OF LONDON}

lcaving the nest. The southern migration of this bird takes place in September.

The adult Wryneck has the general ground colour of the upper parts pale grey, delicately pencilled and vermiculated, mottled and barred with darker grey and various shades of brown; the wings are brown, barred with pale chestnut on the outer webs of the quills; the tail is similarly coloured to the rest of the upper parts; the under parts are buff marked with narrow bars and spots of dark brown. Bill brown; tarsi and toes brown; irides dark brown. Length 7 inches. The nestling does not differ in colour to any marked degree from its parents, but it possesses a peculiar heel-pad (conf. Ibis, I 89 I, p. I 49). 


\section{TH E CU C K O O}

CUCULUS CANORUS

Local names in surrounding counties:

Status in British Avifauna: A common and widely distributed summer visitor.

Radial Distribution within fifteen miles of St. PAul's: I scarcely like to hazard a statement as to how near to Wren's masterpiece the voice of the Cuckoo has been heard. I have met people who stoutly maintained the early morning presence of the Cuckoo in the Temple Gardens, and in St. James's Park, a little further west. Without in any way wishing to cast doubt upon the observation, I can state that the bird has frequently been detected in Hyde Park, in Kensington Gardens, Holland Park, Battersea Park, Regent's Park, and Victoria Park. A little outside these limits the Cuckoo is still oftener heard in such places as Peckham, Clapham, Brompton, Shepherd's Bush, Kensal Rise, Kilburn, Haverstock Hill, Highbury, Stoke Newington, and Clapton. Beyond the six-mile radius the Cuckoo is of increasingly common occurrence, and there is no rural suburb of the Metropolis that at one time or another, in April, May, and June, does not echo its cheerful voice. How close it actually breeds to the central districts is another difficult problem to solve, but it probably does so in any locality where it can find a suitable nest in which to place its alien egg. The breeding range would then be pratically coincident with the distribution of the many small insectivorous birds that breed within the Metropolitan suburbs.

The Cuckoo reaches London about the middle of April. For weeks before this there are usually many records in the newspapers to the effect that the bird has been heard in this locality or that, but they are all untrustworthy, and notwithstanding all that may be said 


\section{THE BIRD-LIFE OF LONDON}

to the contrary I flatly refuse to believe that the Cuckoo has ever reached England in March unless a specimen be actually shot and identified by some competent authority. Every year, like the sea-serpent and the big gooseberry, the Cuckoo question becomes acute for a week or so, until April brings the dear little stranger without further doubt or controversy. Fortunately he begins his song almost at once, and as the birds wander about a good deal upon their arrival the welcome note is frequently heard in most unlikely spots. The note is too well known to require uescription here, but I may say that it is unquestionably dttered by the male alone, often during flight, is continued with great persistency through May, begins to fall off in June, and finally ceases in July. Towards the end of the singing period the cry very often consists of three notes, the first syllable being repeated. The note of the female is a peculiar sound, something like that made by water bubbling from a bottle. The Cuckoo is seldom seen in company except during the laying season, and only occasionally visits the ground, spending most of its time in the trees. It may sometimes be seen flying from onc tree to another across the open fields or along the hedgesides, and it will be noted that the flight is rapid and buoyant, the wings beating rapidly and the long tail closed and held horizontally. After alighting the bird frequently expands its fan-shaped tail, dips its body, and utters a chattering cry. Upon the ground its short legs render its movements awkward, and it progresses in short leaps or hops. The food of the Cuckoo consists chiefly of insects and larvæ, many of which it obtains amongst the foliage ; the larvæ of the Dunker Moth and the Oak-egger are much sought. The young are fed on insects, worms, and grubs, the food of their foster-parents. There is much in the economy of the Cuckoo of profound interest, and bearing on some of the most puzzling of biological questions, which, however, it is impossible to deal with 244 


\section{THE CUCKOO}

in a volume like the present. I have written much on the Cuckoo, for its life-history has always had a special interest for me, and I would refer readers to my several books, where much of the bird's economy' has been discussed. 'The eggs of this species, I need scarcely repeat, are laid in the nests of some small insect-feeding bird, that acts the part of foster-parent, hatching them and tending the young Cuckoo until it can forage for itself. The eggs are laid during the latter half of May and the beginning of June, the birds pairing in due course. It is still an undecided question how many eggs each female lays during the season, possibly from five to eight, each being deposited on the ground first and then carried in the mouth and placed in the selected nest. They vary a good deal in colour, and are remarkably small for the size of the parent. They often, but by no means invariably, resemble those in the nest of the selected species. The most frequent type is greyish or greenish white, spotted, speckled, and blotched with various shades of reddish and olive brown, intermingled with a few specks of dark brown. The Cuckoo leaves us in August and September.

The adult Cuckoo has the general colour of the upper parts slate-grey; the wings are brown, barred on the inner webs with white; the tail is dull black, tipped with white and obscurely barred with the same; the throat and breast are pale grey, the remainder of the under parts greyish white barred with brown. Bill black, yellow at the edges; tarsi and toes yellow; orbits and irides yellow. Length I4 inches. The nestling has the upper parts brown barred with rufous and spotted with white, the under parts pale brown barred with darker brown. It is nearly two years before the fully adult dress is assumed, but a description of the intermediate phases, which are very complicated, would require more space than can be assigned here. 


\title{
THE KINGFISHER
}

\author{
ALCEDO ISPIDA
}

LOCAL names in surrounding counties :

Status in British Avifauna: A widely distributed if local resident, but has been more or less exterminated in many localities.

Radial Distribution within fifteen miles of $\mathrm{S}$. Paul's: The Kingfisher is occasionally seen on the Thames from Battersea upwards, and it also frequents the Wandle, Beverley, Brent, Colne, and Lea, as well as the Paddington Canal, at no great distance from the central portions of our radius, besides paying irregular visits to various minor streams, watercress-beds, sewage-farms, and open sheets of water, even as centrally situated as Kensington Gardens. An odd example was once captured at Camden Town. It is, however, a very local species, nowhere numerous, and its breeding-places are few and far between. In some localities the bird has almost been exterminated, or is rapidly decreasing in numbers; in others, I am pleased to record, it is certainly on the increase, and a strict enforcement of the law which gives it protection in the London suburbs should enable it to become a yet commoner bird. It seems a pity even to indicate the approximate breeding range of the Kingfisher round London, even so far as it is known to myself and several valued correspondents, so I refrain from doing so. I know only too well how the bird is hunted near London, and quite recently an instance of this came to my knowledge from the Brent district, near Wembley, where a nest was wantonly destroyed, and the birds have quite deserted the place. There are still Kingfishers close to London City; greater publicity would only tend to disturb them.

The Kingfisher, the most brightly coloured British 246 

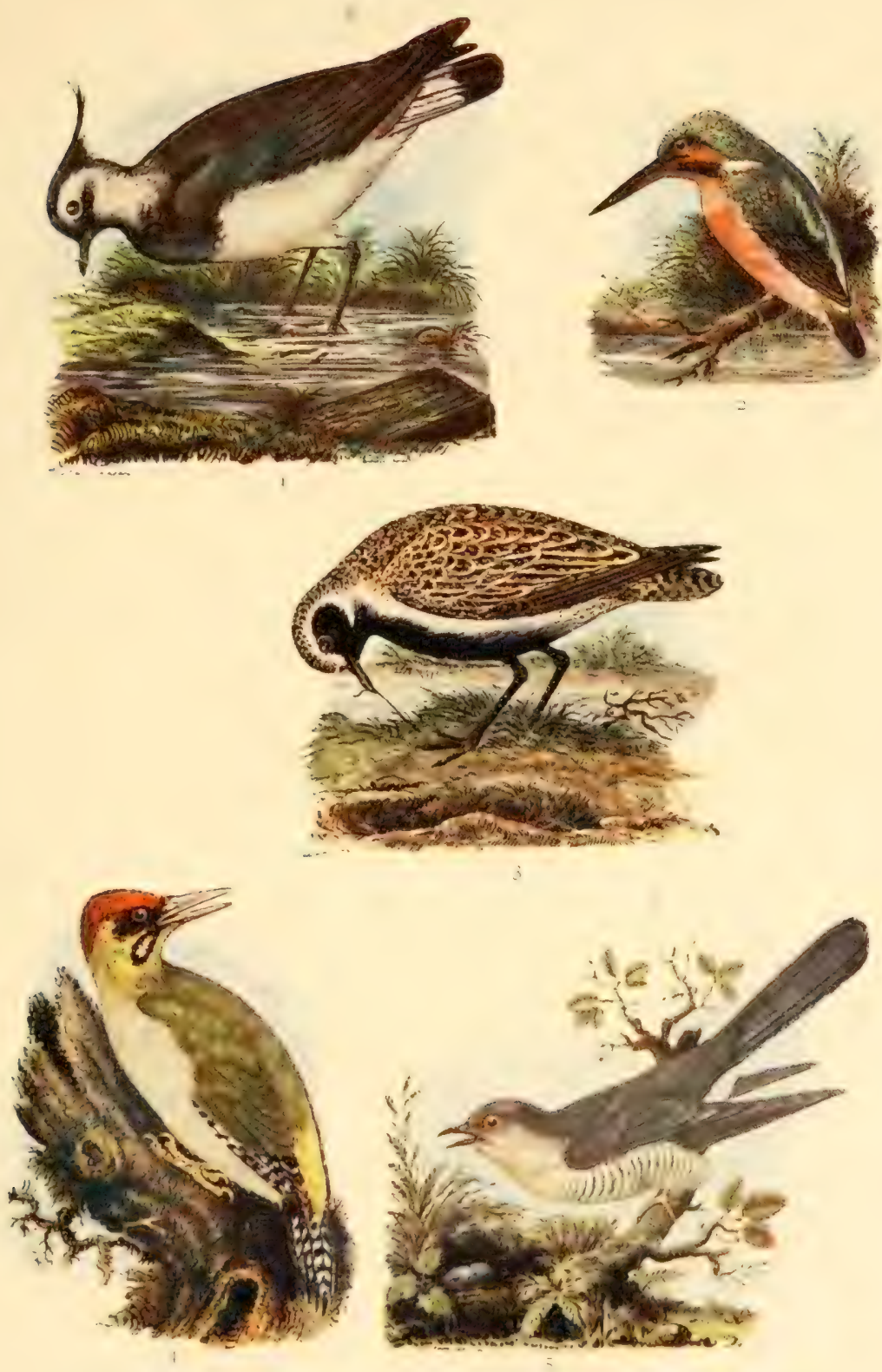

1. Lapwing. 2. Common Kingfisher. 3. Golden Plover. 4. Green Woodpecker. 5. Cinckon 



\section{THE KINGFISHER}

bird, should be one of the most cherished species inhabiting the London area, an interesting ornament to many a quiet pool and waterway in the Metropolis, but unless sentiment can be invoked for its protection Acts of Parliament are useless, and this beautiful gem of the feathered world will sooner or later become extinct therein. All it asks is to be let alone; and then we can imagine a time when even the grimy barges lying high and dry on the black mud between bridges will become a restingplace for this charming bird! Somehow the appearance of the Kingfisher seems always to come unexpectedly, and in the nature of a surprise. Generally a transient glimpse is obtained of the bird as it darts like an indistinct patch of blue down the stream, we know not from where; less frequently we start it from its resting-place above the water, where it has been intently watching our approach, escaping notice until well on the wing. It is wary enough; and though so brightly clad its small size and habit of sitting so perfectly still assist it in eluding discovery, until, with a feeble cry of peep-peep, it darts hurricdly away. The Kingfisher is solitary enough, each bird having some particular haunt, but sometimes an abundance of food will attract several individuals to the same spot. The food of this species consists of small fishes-notably the fry of many fresh-water species-the larve of various aquatic insects, shrimps and other small crustaceans, all the indigestible parts being cast, mostly in the roosting-or nesting-place. Much of this food is obtained by the bird plunging in to the water and seizing it with the long bill. Patiently and silently the bird sits on some perching-place above the water, waiting and watching for prey, and there are few prettier sights, if one can only be fortunate enough to observe the process, than to see the Kingfisher obtaining a meal. The breeding season of the Kingfisher is rather irregular, and although but one brood is reared in the year the eggs may 


\section{THE BIRD-LIFE OF LONDON}

be found during April, May, and June. Its nest is seldom far from the waterside, and is made usually in a hole in the bank. In some cases this is dug out by the old birds, in others a disused rat-hole is utilised. At a distance often of several feet, in a small chamber, and on fish-bones and other food refuse, the hen lays from six to ten polished white eggs. The young are tended for some time after they leave the nest, but finally disappear from the locality.

The adult Kingfisher has the general colour of the upper parts, including the cheeks, emerald-green, the back and upper tail-coverts cobalt-blue, the head, cheeks, and wing-coverts spotted profusely with the latter colour; the under parts are bright chestnut, shading into buffish white on the throat; the sides of the neck below the crest are buffish white. Bill black; tarsi and toes red; irides dark brown. Length $7 \frac{\mathrm{x}}{2}$ inches. The nestling resembles the parents in general colour, but the under parts are browner and marked with greenish grey; the bill, tarsi, and toes are brown. 


\section{THE NIGHTJAR \\ GAPRIMULGUS EUROPAUS}

Local names in surrounding counties: "Night Hawk" (Essex).

Status in British Avifauna: A common and widely distributed summer visitor to all districts suited to its needs; less numerous in Scotland and Ireland.

Radial Distribution Within fifteen miles of $\mathrm{S}_{\mathrm{T}}$. PAUL's: 'There are many suitable haunts for the Nightjar within the Metropolitan area, and the bird takes such an advantage of them that it is quite common in some parts of it. Probably the nearest haunt of the Nightjar to St. Paul's is Hampstead. 'Then amongst the more central suburbs I may mention as haunts Dulwich, Streatham and Tooting Bec Commons, Ealing, Twyford, and Wembley. The bird is very common in Richmond Park, also at Wimbledon, Coombe Wood, Bushey, Barnes Common, and the Kew, Osterley, and Hanwell districts. It becomes more local in the northern and eastern suburbs, but I can mention Elstree, Enfield, and Epping as haunts. There are many haunts of the Nightjar in Kent, amongst the Crays and elsewhere, and the bird again becomes exceptionally common in the Croydon area, especially in such spots as Shirley Heath. Continuing our way across Surrey again, the bird is common, and universally distributed throughout the open woodlands, commons, and heaths to Banstead, Epsom, and Esher.

The Nightjar is another late migrant, not reaching its London haunts until about the middle of May (although Mr. W. B. Tegetmier records its arrival at Finchley on April 28, I906-an exceptional occurrence) leaving them again in September. As the Nightjar is only abroad at dusk and during the hours of night, its actions are not very easily observed. Skulking during 


\section{THE BIRD-LIFE OF LONDON}

the daytime amongst ferns and on heaps of stones, or perched motionless lengthwise, not across, some broad branch, where its mottled plumage makes it resemble a patch of lichen or dead moss, it remains inactive until sunset, when it sallies forth in quest of food. Its soft plumage renders its flight Owl-like and noiseless, and in a ghost-like way it beats to and fro along the wood-sides or over the open heaths and fern-brakes, under the trees, and round about feeding cattle, in quest of the moths, beetles, and other night-flying insects upon which it subsists. During the earlier months of its stay the Goatsucker is a somewhat garrulous bird, and at intervals utters a very singular cry whilst flying, resembling the syllables co-ic, co-ic, and when sitting a churring note, or loud purring, which rises and falls in cadence and may be heard for some distance. Sometimes the birds may be seen chasing and buffeting each other in the gloom, and often fly right overhead or just above the bracken, the sharp snap of the bill at intervals telling when an insect has been secured. Very rarely the Nightjar is seen abroad during daylight, usually when it has been disturbed, and then it seems only anxious to settle into cover again. 'The short legs of this bird render its progress upon the ground slow and awkward. It probably pairs for life, resorting to the same places yearly to breed, and although by no means gregarious several " nests" may frequently be found within a small area. The Nightjar, however, does not make a nest, as the term is understood, but lays its two eggs on the bare ground, on a fallen tree-trunk, or on a stone-heap. They are very beautiful objects, elongated in form and nearly oval, varying from white to pale cream in ground colour, mottled, blotched, streaked, and veined with various shades of brown and violet grey. Only one brood is reared in the season.

The adult male Nightjar has the general colour of the 250 


\section{THE NIGHTJAR}

plumage greyish white and buff, charmingly vermiculated with darker grey and black, and barred and spotted, especially on the crown and under parts; the sides of the neck and the cheeks are marked with a white spot; the two outside tail-feathers are broadly tipped with white, and there is a large white spot near the centre of the first three primaries. Bill brownish black; tarsi and toes brown; irides brown. Length Io $\frac{x}{2}$ inches. The female closely resembles the male in general colour, but the white patches on the wings and the white tips to the tail-feathers are absent, whilst the spots on the neck and cheeks are pale buff. The nestling is without the white spots on the wings and tail, the former being marked with chestnut-buff bar-like spots on the inner webs, and spots of the same colour on the outer margin of the outer web. 'The tail is barred with light and dark brown; the smaller wingcoverts are nearly black, mottled with rusty brown. The claw of the middle toe is curiously serrated or toothed, not only in the adults, but in the young. 


\section{THE'RING DOVE \\ COLUMBA PALUMBUS}

Local names in surrounding counties: "Ring Dow" (Essex).

Status in British Avifauna : A universally distributed and common resident in all woodland districts, its numbers largely increased in autumn by migrants from the Continent.

Radial Distribution within fifteen miles of $\mathrm{S}_{\mathrm{T}}$. PAUL's: The Ring Dove is rapidly becoming one of the most familiar birds in the central parts of the Metropolis, and a convincing object-lesson of the tameness of wild creatures when left unmolested by man. The increase and dispersal of the Ring Dove in London during the past twenty years is one of the most remarkable facts in the ornithology of the Metropolis. Many years ago it was known that a few pairs of this Dove nested in the grounds of Buckingham Palace. It is apparently from this centre that the bird has dispersed over London, and it may at the present time be found nesting not only in all the large urban parks, but in many of the squares and open spaces right up almost to the walls of the Cathedral. There were several pairs of Ring Doves nesting last spring in Gray's Inn ; several more in New Court and other parts of the Temple; others in Lincoln's Inn, and a pair in Upper Thames Street. From these central districts the Ring Dove may be found nesting in many parts of London even in the most busy thoroughfares. I have seen nests on the Embankment, in Leicester Square, in the plane-trees along the Euston Road (there is a nest just outside Baker Street Station), near the Royal Oak, Paddington, in the grounds of the Lock Hospital, in Connaught and Berkeley Squares, as well as many other places. The bird is also common and widely dispersed over 252 


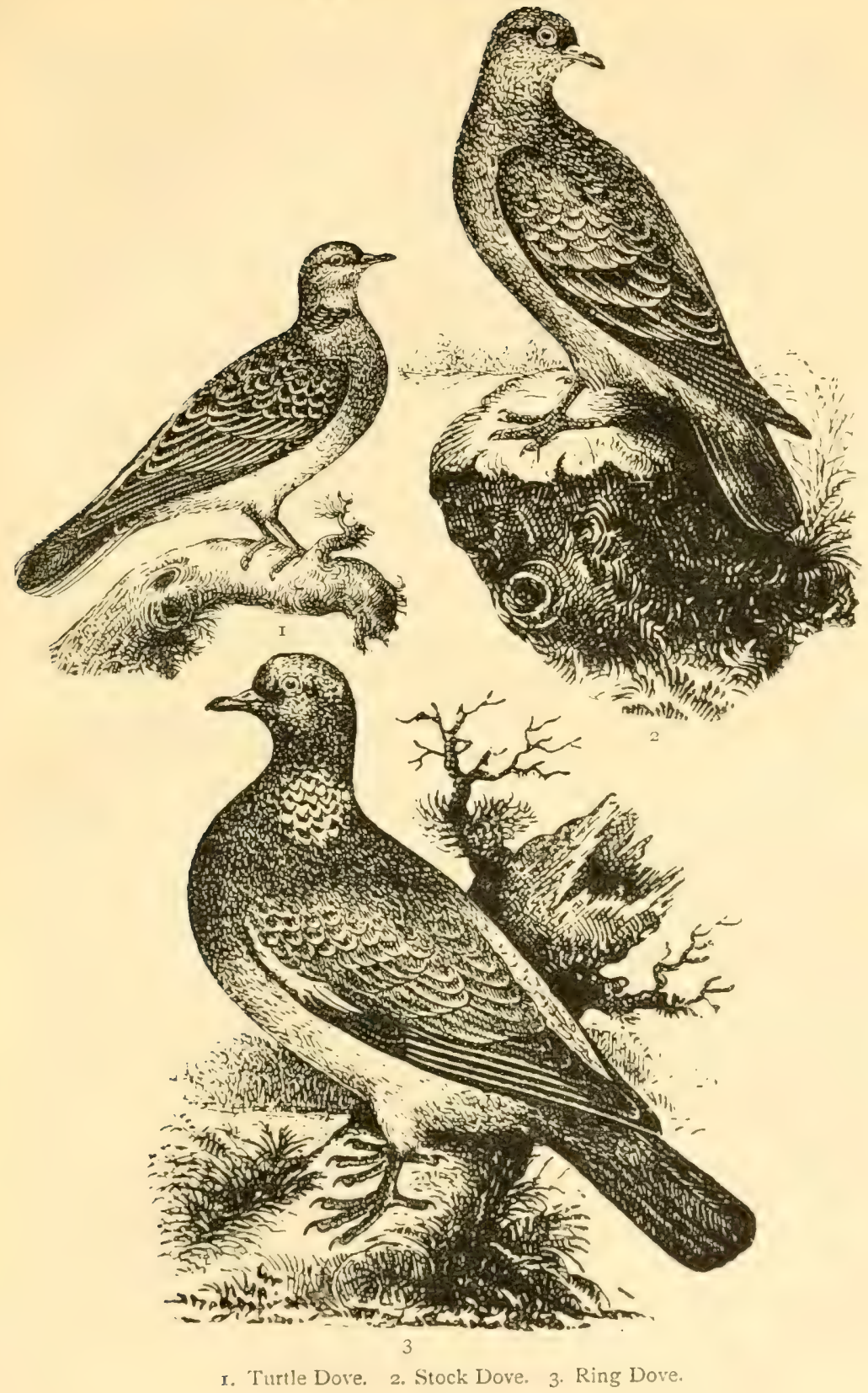





\section{THE RING DOVE}

the rural and outlying suburbs, but in some of the western districts seems more abundant in winter than in summer.

Although not so common as Sparrows and Starlings, the Ring Dove has now become one of the most familiar of London's birds, and in at least several cases has interbred with the ordinary dove-cote Pigeons of the Metropolis. There is scarcely a park, a square, or a public garden in London where this bird may not be seen, either clumsily waddling about the grass or sitting, all unmindful of the din of the traffic, in the plane and other trees that relieve the dreary monotony of the streets. As a dweller in the country I knew the Ring Dove as one of the shyest and wariest of birds ; in London I was simply amazed to see it so tame and confiding, walking about the parks, picking up bread scattered by passers-by, and almost remaining to be kicked out of the way. Although at all times socially inclined, the Ring Dove, even in London, does not yet breed in colonies, and in autumn it congregates into flocks. Its flight is direct and powerful, and in the air it may readily be recognised by the white neck-patches, which are very conspicuous. Its note is a full, rounded coo, variously modulated, especially during the love season, which may be said to begin in March. Its food consists of all kinds of grain, beans, peas, fruits, and berries, acorns, beech-mast, and tender shoots of clover. In London it will eat almost anything of a vegetable nature. The Ring Dove pairs for life, and commences nesting duties as early as March, continuing to rear brood after brood until the autumn. In the London area the nest is usually made in a tree or tall bush, and is a slight, flat platform of interlaced twigs. The two eggs are white. I have often remarked that in autumn a very considerable reduction in its numbers in London takes place, and continues through the winter, the birds apparently retiring to the country districts, as so many Sparrows do in autumn. 


\section{THE BIRD-LIFE OF LONDON}

The adult Ring Dove has the general colour of the upper parts pale slate-grey, with a metallic sheen of purple and green on the neck; on each side of the neck is a scaly patch of yellowish white feathers; the mantle, scapulars and innermost secondaries are greyish brown; the outer web of some of the wing-coverts is white; the wings are dark brown margined with white; the tail is dark brown, with a broad sub-terminal band of grey; the throat is lavender-grey, the breast lilac-grey, the abdomen, flanks, and under tail-coverts lavender-grey. Bill reddish orange at the base, yellow at the tip; tarsi and toes pinkish red; irides pale yellow. Length I 6 inches. The first plumage somewhat closely resembles the adult, but is browner, and the white patches on the neck are absent. The nestling is slate-grey, covered with straw-coloured hairy down. 


\section{THE STOCK DOVE}

COLUMBA ENAS

Local names in surrounding counties: "Wild Blue Rock Pigeon" (Essex).

Status in British Avifauna : A local but widely distributed resident in all suitable parts of England and Wales, but only breeds sparingly in Scotland and Ireland.

Radial Distribution within fifteen miles of St. PaUL's: 'The Stock Dove, broadly speaking, is nowhere so common or so widely dispersed in the Metropolitan area as the Ring Dove; neither does it penetrate into the most central districts like that species. I have records of stragglers in Battersca Park, and the Hyde Park and Regent's Park areas. It has also been seen in Victoria Park. Beyond these limits it may be found in the Tooting, Sydenham, Wimbledon, and Richmond districts, visits Chiswick and Kew, is found in the Hounslow and Osterley areas, then northwards through Ealing, Acton, Horsenden, Sudbury, Wembley, Harrow, and Bushey. It is also found at Pinner, Stanmore, Elstrce, Mill Hill, Hendon, Barnet, Enfield, Hampstead, Waltham, and Epping, in the latter place said to be on the increase. Wanstead, Ilford, Dagenham, and Rainham are other localities; whilst across the river it is found in the Crays, Dartford, Farnborough, Croydon, Banstead, and Epsom neighbourhoods, as well as in many intervening places. There is a possibility that this bird is considerably overlooked, especially near to central London, where it can readily be confused with the many half-wild domestic Pigeons, although the uniform colour of the back should preclude any possibility of this.

The Stock Dove is partial to well-timbered areas, so many of which form a feature of the London suburbs. It is a shy, wary species, usually seen during summer singly 


\section{THE BIRD-LIFE OF LONDON}

or in pairs about the tall trees, from which its note of coo-0o-up may very frequently be heard during the whole spring and summer. It has the same habit of returning regularly to certain places to roost in big evergreens, or tall trees covered with ivy. Like its congeners it obtains most of its food on the fields, running or walking about the ground in a waddling manner, seldom permitting close approach, and when alarmed taking cover in the trees. This food consists of grain and seeds of many kinds, acorns, beech-mast, and berries. The bird is somewhat troublesome to the farmer and market-gardener, its inroads amongst crops of beans, peas, and newly sown seeds often being serious. As a set-off against this the Stock Dove consumes large quantities of the seeds of noxious weeds, charlock in particular. In autumn it often associates with Ring Doves, but never seems to gather into large flocks like that species, although its gatherings are often considerable. 'To some extent the Stock Dove is social during the breeding season, which commences in April and is often prolonged into the autumn, brood after brood being reared in succession. A hole in a tree or cliff is perhaps the most favourite nesting-place, a pollard trunk often being selected; rabbit-holes and dense masses of ivy on trees and buildings are less frequently chosen. The nest is slight, a mere mat of twigs or straws, and in some cases is dispensed with entirely. The two eggs are creamy white. 'The nestlings remain in their abode until able to fly, when they betake themselves to the open fields.

The adult Stock Dove has the general colour of the upper parts brownish grey, brightest on the back and upper tail-coverts; the wings are blackish brown, bluish grey on the coverts, and grey on the scapulars; there are dark brown patches on some of the coverts and innermost secondaries, forming a broken bar across the wing; the tail is bluish grey on the basal portion, merging into a 256 


\section{THE STOCK DOVE}

darker subterminal band; the neck is grey, with a metallic sheen of green and purple; the breast is vinous, shading into the delicate grey of the rest of the under parts. Bill red at the base, yellow towards the tip; tarsi and toes pinkish red; irides red. Length I 3 to I 4 inches. The young in first plumage closely resemble the adults, but lack the metallic sheen on the neck, the black spots on the wings are only faintly indicated, and the vinous tints on the breast are not so prominent.

\section{THE PIGEON COLONIES OF LONDON}

Brief allusion must here be made to the many colonies of semi-tame Pigeons that are such a very prominent feature in the bird-life of the Metropolis. Some of the most interesting of these may be seen at the Guildhall, the Houses of Parliament, the British Museum, and the various great railway termini; whilst there are innumerable smaller colonies all over London. From a scientific or merely a popular ornithological point of view these colonies of Pigeons do not possess any great interest; but the fact that the tame Pigeon is a descendant of the Rock Dove should be borne in mind. That the tame Pigeon and the Ring Dove interbreed is unquestionable; and I have on several occasions seen undoubted hybrids between the two. 


\section{THE TURTLE DOVE}

TURTUR AURITUS

Local names in surrounding counties: "Little Dove" (Essex).

Status in British Avifauna: A somewhat local summer visitor to all suitable places in England and Wales; rarer in Ireland, and of only accidental occurrence in Scotland.

Radial Distribution within fifteen miles of St. PAUL's: The Turtle Dove is a regular summer visitor to all parts of the Metropolitan area suited to its requirements. It does not appear yet to have invaded, as a breeding species, any of the urban parks and private grounds, yet it occasionally visits some of them during the seasons of migration. It is recorded as a visitor to such comparatively central localities as Wandsworth and Dulwich, Highgate and Hampstead. Further afield in the more rural suburbs it is found in summer at Wimbledon, is fairly abundant at Richmond, Kew, Bushey, Hounslow, Osterley, Sudbury, and Wembley. Thence I can trace it through the Harrow, Pinner, Barnet, Hendon, Enfield, and Waltham districts to Epping, and southwards to Wanstead, Dagenham, and Rainham, across the river into Kent, where Dartford, the Crays, and Farnborough, with many intervening places, are summer haunts. It is also found regularly in the Croydon area, as well as in those of Banstead, Merton, Ewell, Epsom, Esher, Ditton, and Kingston. Beyond our radius there are many haunts of the Turtle Dove, especially in Surrey and in Bucks and Berks.

The Turtle Dove sometimes reaches Greater London by the end of April, but more generally the beginning of May is the time of its arrival. There are many private grounds and orchards in the suburbs to which this species is a regular summer visitor, and the time may come 258 


\section{THE. TURTLE DOVE}

when this pretty bird will regularly resort to the larger parks, especially where thickets and shrubberies abound. Greater precautions, however, will have to be taken against prowling cats, and the hordes of rats that infest these places and constitute the greatest danger to the wild birds frequenting them. The Turtle Dove leaves this country for the south in September. It is a shy and retiring bird, delighting to conceal itself amongst the foliage of trees and tall hedges, from which its pleasant cooing cry sounds most persistently during early summer. It visits the ground to feed, walking about with the usual bobbing gait of its kind, but at the least alarm hurries off with a rattle of wings to the nearest cover. Its food consists of grain and seeds, small fruits and berries, and the tender shoots of clover and other plants. In some of its London haunts, especially in grounds where it is left unmolested, I have often noticed that much of its usual wariness and timidity have disappeared. I saw a pair on one occasion near Hendon flying about a large garden almost as tame as Doves kept in confinement. The note is pleasing, full-toned, and soft, a guttural coo-r $r-r$ coo, oft repeated, and in the love season modulated in various ways. It commences breeding soon after its arrival, and as eggs may be found from May to August in some cases at least more than one brood must be reared in the season. The flat, wicker-like platform that serves for a nest is built in tall bushes and dense hedgerows in preference to high trees. It is made of slender dry twigs, and is so slightly put together that the eggs may often be seen through it from below. These are two in number, and creamy white. As autumn comes on the Turtle Dove becomes more or less gregarious, and flocks of various size frequent the stubbles, turnip-fields, and weed-grown pastures, and migrate without disbanding. These flocks now wander about a good deal, but often return to certain favourite places to roost. 


\section{THE BIRD-LIFE OF LONDON}

The adult Turtle Dove has the head and back of the neck lavender-grey, shading into chestnut-brown on the upper back, with a strong lavender shade on the lower back and rump, and into brown on the upper tail-coverts; the scapulars, innermost secondaries, and some of the wing-coverts are pale chestnut, with darker central markings; the outer wing-coverts are lavender-grey, the secondaries brown washed with grey, the primaries and their coverts brown; all but the central tail-feathers are blackish grey tipped with white, the outermost white on the outer web, the central pair uniform brown; at each side of the neck is a patch of black feathers with lavender tips; the breast is lavender-grey with a rosy suffusion, shading into white on the abdomen and under tail-coverts, and lavender on the flanks. Bill brown; tarsi and toes crimson; irides reddish brown. Length II inches. In the young in first plumage most of the feathers have broad rufous margins, and the neck patches are absent. The nestling is first clothed in thin, hairlike, downy plumes of straw-colour. 


\section{THE PHEASANT \\ PHASIANUS COLGHICUS}

LOCAL names in surrounding counties:

Status in British Avifauna: A common resident, non-indigenous, wherever it is preserved.

Radial Distribution within fifteen miles of $\mathrm{S}_{\text {t. }}$ PAul's : 'The Pheasant is best known to Londoners as an attractive item of the game-dealer's stock between October and January; still it may be met with in a wild state in one or two localities well within the nine-mile radius. Probably its nearest haunt to St. Paul's is Wimbledon Common, where I have frequently watched its ways in the wooded portions of that grand retreat for wild life. Then it is found in Richmond Park, breeding in the various enclosures from which the public is excluded, but often to be seen furtively wandering outside them or concealing itself amidst the ample cover of the bracken. Coombe Wood, between these two localities, is another London haunt of the Pheasant. Elsewhere round the Metropolis the distribution of this species calls for little further comment. It is found in many localities in the remote outlying districts, but nowhere in a normally wild state, and only in places where it is preserved for the sport it yields. Stragglers occasionally wander into other areas, but in no case do these include any of the central districts. It may be of interest to note that the first record of the Pheasant as a British bird is an Essex one.

Plenty of cover and freedom from molestation are absolutely essential for the Pheasant. Its inherent shyness and timidity demand in our country the same conditions of existence as are enjoyed by its wild progenitors in the jungles of the East. Although the Pheasant spends most of its time upon the ground, it roosts in trees and tall bushes, and seldom wanders beyond easy reach of dense cover of 


\section{THE BIRD-LIFE OF LONDON}

some kind, such as plantations and woods with plenty of undergrow th or thick hedges. When such crops as clover, grain, turnips, and so forth are sufficiently matured to afford shelter the bird is very fond of skulking amongst them, but at nightfall it always resorts to a roosting-place amongst the branches. It is a fairly social bird, and in well-stocked covers may be seen in companies feeding and running together. During the pairing season, however, the cocks are quarrelsome and pugnacious, fighting amongst themselves for the hens, but as soon as the eggs are laid this martial spirit dies out and they live in peace together. The Pheasant is wary and watchful when feeding out of cover, either on the fields or the broad drives in the woods, and at the least alarm the cocks usually hurry off at once, running or flying to a place of concealment, but the hens generally crouch flat to the ground, where their brown plumage very effectually shields them. The food of this species consists of grain, peas, beans, tender shoots of clover and other herbage, acorns, beech-mast, berries of many kinds, worms and insects, especially ants and their eggs. In places frequented by Pheasants the harsh crow or cor-r-k of the male is heard occasionally through the day, but towards night the crowing becomes almost continuous as the birds retire to roost. In this country the Pheasant is polygamous, but in its native wilds in Western Asia it appears to be monogamous. Pairing takes place in March, and the eggs are laid in April and May. The scanty nest, a slight hollow, lined with dead leaves or dry scraps of herbage, is made by the hen, in some quiet, sheltered hedge-bottom or amongst tangled undergrowth in the coverts. The eight to a dozen eggs are usually uniform olive-brown, but sometimes bluish green, one of the latter being seen in a clutch of the ordinary colour. The hen takes sole charge of the brood, but she is not a very careful mother, and seldom succeeds in bringing all the chicks to maturity. 262 


\section{THE PHEASANT}

The Pheasant is too well known to require detailed description here. The head and neck of the male are dark green, shading into bronze on the crown and into purple on the sides and front of the neck; the mantle, breast, and flanks are orange, those of the flanks edged with purple, the others with purplish green; the back and scapulars are marked with buff, black, orange, and purple; the lower back and rump are maroon shot with purple and green; the wings are brown; the long tail is metallic olive barred with brown. Bill pale horn-colour. Length about 36 inches, with tail. The female is mostly a mottled medley of black, buff, chestnut, and brown. 


\section{THE PARTRIDGE}

PERDIX CINEREA

Local names in surrounding counties:

Status in British Avifauna: A common and widely distributed resident in all districts where it is preserved.

Radial Distribution within fifteen miles of $\mathrm{S}$ t. PAUL's: Almost precisely the same remarks apply to the distribution of the Partridge in the Metropolitan area as those given concerning that of the Pheasant. The bird may be met with occasionally at Wimbledon and in Richmond Park, and is found in the Croydon and Horsenden district. It wanders from time to time into localities where it is not preserved, but otherwise the Partridge only haunts ground where it is afforded protection from man. Under these conditions it is a fairly common resident in the remoter portions of our radius.

In walking over the fields or along the sides of the thick, low hedges where the bottoms are full of tangled cover the student may be occasionally startled by the sudden rising of the Partridge, which with a rattle and a whistling whirr hurries alarmed away. During the greater part of the year the bird lives in coveys or flocksthat is to say, until they become decimated by the gunner -haunting the turnip-fields, stubbles, rough, open commons, and newly sown grain-lands. It is a terrestrial species, spending its whole existence upon the ground, where it roosts. It is shy and wary, skulking low amongst the herbage when alarmed, and often runs quickly through the cover to escape in preference to flying, only using its wings when compelled or when suddenly disturbed. Its flight is powerful and prolonged, the wingbeats rapid and noisy, and occasionally the bird skims for a long distance on stiff and arched pinions. The callnote of the Partridge is a shrill kirr-rr-ric, uttered by both 264 


\section{THE PARTRIDGE}

sexes, more especially at morn and even and during the mating season. If heard later on in summer it is an omen of disaster, telling that the brood has come to grief. The food of this species consists of grain, tender shoots of clover and other plants, blackberries and other small wild fruits and berries, worms, insects, and larvæ, snails, and especially ants' eggs, the latter serving as the principal fare of the chicks in many cases. The bird is most active during the morning and evening, and in the hot hours is very fond of basking on some open spot and dusting itself. The covey sleeps on the fields, the birds forming a ring, with heads turned outwards. The Partridge is monogamous, and in March as a rule separates into pairs for breeding purposes; the old birds possibly mate for life, but the young of the previous season unite at that time. The nest is a mere hollow in some hedgebottom, amongst growing clover, grass, or grain, or under a mass of herbage on rougher ground. It is lined with a little dry grass or some dead leaves, and the eggs, from ten to twenty according to the age of the hen, are uniform olive brown. Occasionally a nearly white or pale green specimen is seen in a clutch of the normal colour. The broods and their parents keep together for the rest of the season, grain-fields and turnip-patches being favourite haunts.

The adult male Partridge has the crown and nape brown streaked with palc buff, the forehead and sides of the head reddish chestnut; the general colour of the rest of the upper parts is slate-grey vermiculated or sprinkled with black and barred with buff and chestnut; the wings are brown, the lesser and median coverts marked on the inner web with chestnut and with buff shaftstripes; the tail is chestnut; the throat and neck are chestnut; the breast is grey, below which, and extending on to the abdomen, is a crescentic patch of dark chestnut; the remainder of the under parts is pale 


\section{THE BIRD-LIFE OF LONDON}

grey; behind the eye a scarlet patch of bare skin. Bill pale lead-grey; tarsi and toes pale grey; irides brown. Length $12 \frac{x}{2}$ inches. The female closely resembles the male in general coloration, but may always be distinguished, according to Mr. Ogilvic Grant, by having the wing-coverts barred with buff, not with pale shaft-lines, as in the male. The young in first plumage have no chestnut on the head and neck, and the general tone of colour inclines to buff, not to grey, and the first primary is pointed at the end, not rounded. This latter peculiarity is retained until the following autumn.

1. Mention may here also be made of the RED-LeGGeD Partridge (Caccabis rufa), which has been introduced into Bucks and Berks, where it is an uncommon resident. The same remarks apply to Surrey; and the bird occurs accidentally in Middlesex. It cannot fairly claim further notice in an account of the birds of London.

The QuaIL (Coturnix communis) is a rare yet breeding species in some parts of rural Surrey; is met with on passage in Bucks and Berks; is of rare occurrence in Middlesex; and although it has bred in many parts of Essex there is no instance recorded within the fifteenmile limit. 


\section{THE GOLDEN PLOVER}

CHARADRIUS PLUVIALIS

L.OCAL names in surrounding counties:

Status in British Avifauna : A summer resident on the moors and uplands from Derbyshire northwards, breeding very locally in the south-west of England and in Wales, becoming more numerous in Scotland and Ireland; in winter visits the lowlands and coasts, and is then more widely dispersed, its numbers being increased by migrants.

Radial Distribution within fifteen miles of $\mathrm{S}_{\mathrm{T}}$. Paul's: 'The Golden Plover is too scarce and local a visitor to the Metropolitan area to excite much interest in the student or lover of London bird-life. It is, however, a regular visitor to "London" either on migration or in winter, and is recorded from Epsom, Kingsbury, Stanmore, and the Wanstead Flats. There are various localities where this species might reasonably be expected, such as marshy meadows, sewage-farms, watercress-beds, and so forth, but its visits, if any, are only accidental and transient.

In autumn the Golden Plover leaves the moors and mountains of the north to pass the winter on the lowland marshes and the coasts, and it is during these migrations and the return ones in spring that the bird is most likely to be observed in the vicinity of London. Its favourite haunts during winter are low-lying coasts and salt marshes, where it searches for a variety of marine small animals, worms, and grubs, upon which it subsists. It runs nimbly about the ground, living in flocks of varying size, which usually assume a $\mathbf{V}$-shaped formation when passing from one district to another. It retires in March and April to the moors to breed, making a scanty nest upon the ground-a mere hollow, lined with a few scraps of dead 


\section{THE BIRD-LIFE OF LONDON}

herbage and leaves. 'The eggs, laid in May, are four in number, pyriform in shape, and buff in ground colour, handsomely blotched and spotted with blackish brown, purplish brown, and grey. A return to the lowlands commences as soon as the young are strong on the wing. In winter plumage, the dress in which the Golden Plover generally appears in the London area, the upper parts are black spotted with yellow, and the under parts are white, marked on the breast and flanks with dusky brown. In summer the under parts are black. Bill black; tarsi and toes brownish black; irides brown. Length io inches. The female closely resembles the male in general colour, but is more marked with dusky brown on the under parts in winter, and the black of the under parts is mixed with white in summer. The young in first plumage closely resemble the parents in winter dress.

I may here mention that the Grey Plover (Squatarola belvetica) has been obtained at Forest Gate in $\mathbf{I} 87 \mathbf{I}$. It may always be distinguished from the preceding bird, which it resembles somewhat, especially in size, by its minute hind toe, which is lacking in the Golden Plover and its allies. 


\section{THE L A P I N G \\ VANELLUS CRISTATUS}

Local names in surrounding counties: "Green Plover," "Horned Pie," "Black Plover" (Essex).

Status in British Avifauna: A widely and generally distributed resident, commonest in Scotland and Ireland, wandering much in autumn and winter, its numbers increased at the former season by migrants from the Continent.

Radial Distribution within fifteen miles of St. PAUL's: It is recorded that the Lapwing formerly bred in Richmond Park, but it is very seldom seen there nowadays, and does not nest anywhere probably within our limits, unless in one or two scattered localities in the most outlying and rural situations. The bird, however, is a fairly well-known winter visitor to the Metropolitan area, small flocks locally appearing on the various sewagefarms and agricultural lands. It is a tolerably regular visitor to the Wanstead and Epping areas, to various parts of North London, Mill Hill, Elstree, Stanmore, Pinner, Harrow, Wembley, and Hendon. I have also records from Southall, Hounslow, Osterley, Bushey, Wimbledon, Kingston, Merton, Banstead, Croydon, Epsom, the Crays, and Dartford. It would be very interesting to ascertain how close to London City the Lapwing actually breeds. Our ignorance on the point only shows how little we know concerning the rarer birds of the Metropolitan district, and how many interesting facts remain to be elucidated by the worker in this populous area. I can record this species breeding close to Uxbridge Common in the spring of 1905 ; and I have reason to believe that scattered pairs do so between that place and Northolt; whilst considerable numbers nest at Kenton, in the Kingsbury district, whence I 


\section{THE BIRD-LIFE OF LONDON}

have eggs taken as recently as 1907 . It also breeds near Edgware.

During summer the few pairs of Lapwings that breed within the area of Greater London will be found scattered over the grass-meadows and newly sown grain-fields. They cannot readily be overlooked, for as one walks across these places the birds rise and circle in troubled, heavy flight, their peculiar mewing notes of weet-aueet, pee-ueet-ueet, and their strongly contrasted colours -looking mostly black and white-and broad, ample wings rendering identification easy. If not pursued the big birds eventually settle again, dropping down one by one, often with raised wings, which are held open for a moment ere being folded to the body. Upon the ground the bird looks almost mouse-colour and the long crest is easily remarked with a good glass. The bird continues more or less social through the summer and in autumn becomes quite gregarious, assembling into flocks, which wander about in quest of food. It is then that they are chiefly remarked upon the open ground near sewage-farms, market-gardens, marshy commons, and similar spots. The food of the Lapwing consists of worms, snails, insects and larvæ in summer; but in winter small seeds, tender shoots, and a variety of marine creatures are eaten. Much of this food is sought after dusk, an hour at which the bird becomes very noisy, especially during early summer. The Lapwing breeds in April and May; in very early seasons eggs may be found at the end of March. So far as London is concerned the nest is generally made on the open fallows, or amongst growing grain. This nest, if nest it can be called, is a mere hollow in the ground, sometimes the footprint of a horse or cow, in which is scattered, but not always, a few scraps of dry grass or leaves. The four pyriform eggs range from buff to pale olive-blue or green in ground colour, spotted and blotched with 270 


\section{THE LAPWING}

blackish brown, paler brown, and ink-grey. 'These are the eggs sold as delicacies in early spring, but they come from localities where the Lapwing is very much more abundant than it is near London. When the young can fly the birds begin to assemble into flocks for the autumn and winter.

The adult Lapwing in breeding plumage has the head and neck behind and below the eye almost uniform white; the head in front of the eye, and reaching downwards to the breast and upwards to the crown (which is decorated with a long bunch of recurved plumes) is black shot with purple and green, but more or less mottled with white on the lores, ear-coverts, and over the eye ; the rest of the upper parts are metallic green, shot with purple on the scapulars and purplish green on the wing-coverts; the upper tail-coverts are chestnut, the under ones paler; the wings are black and white; the tail has the basal portion white, the terminal portion black, with small white tips; on the outermost feathers the white predominates, gradually decreasing towards the centre The under parts, with the exceptions already noted, are white. Bill black; tarsi and toes flesh-pink; irides brown. Length- I 3 inches. In autumn the throat is more or less uniform white. The young in first plumage have most of the feathers of the upper parts tipped with buff, and the crest is much shorter. The young in down are pale reddish brown spotted and splashed with black, white below, with a dark band across the breast. 


\section{THE RINGED PLOVER}

EGIALITIS HIATICULA

Local names in surrounding counties: "Stone-runner," "Ring Dotterel" (Essex).

Status in British Avifauna: A passing migrant in spring and autumn, a few possibly remaining to breed on the coasts of Kent and Sussex, and frequenting suitable inland places as well as the coast.

Radial Distribution within fifteen miles of St. PAUL's : The Ringed Plover is met with every year during the seasons of spring and autumn migration in various spots in the Metropolitan area. It is occasionally seen on the foreshore of the Thames about Battersea, and round the margins of the filtering-beds there, whilst the various reservoirs in the suburbs, Kingsbury, the Welsh Harp, Wimbledon Lake, and many other similar places tempt it to make a short sojourn. Whether the large resident race of the Ringed Plover (Egialitis major) ever visits London I am unable to say, as it is very difficult of identification unless closely examined. The fact that Ringed Plovers are usually only seen in our limits during spring and autumn is strong presumptive evidence that these individuals belong to the smaller race. At any rate the facts present a very interesting problem for the London ornithologist to solve.

This little Plover is a dweller by the waterside, where it may be watched running daintily to and fro in quest of food. If disturbed it rises and flies away along the shore or makes a détour over the water at no great height, again alighting close to the water's edge. Occasionally it wades into the shallow water, or trips lightly over the mud. It seems by no means at home on the banks of these London waters, and seldom makes a prolonged stay. Its alarm-note is a loud, shrill too-it, the call-note a sound 272 


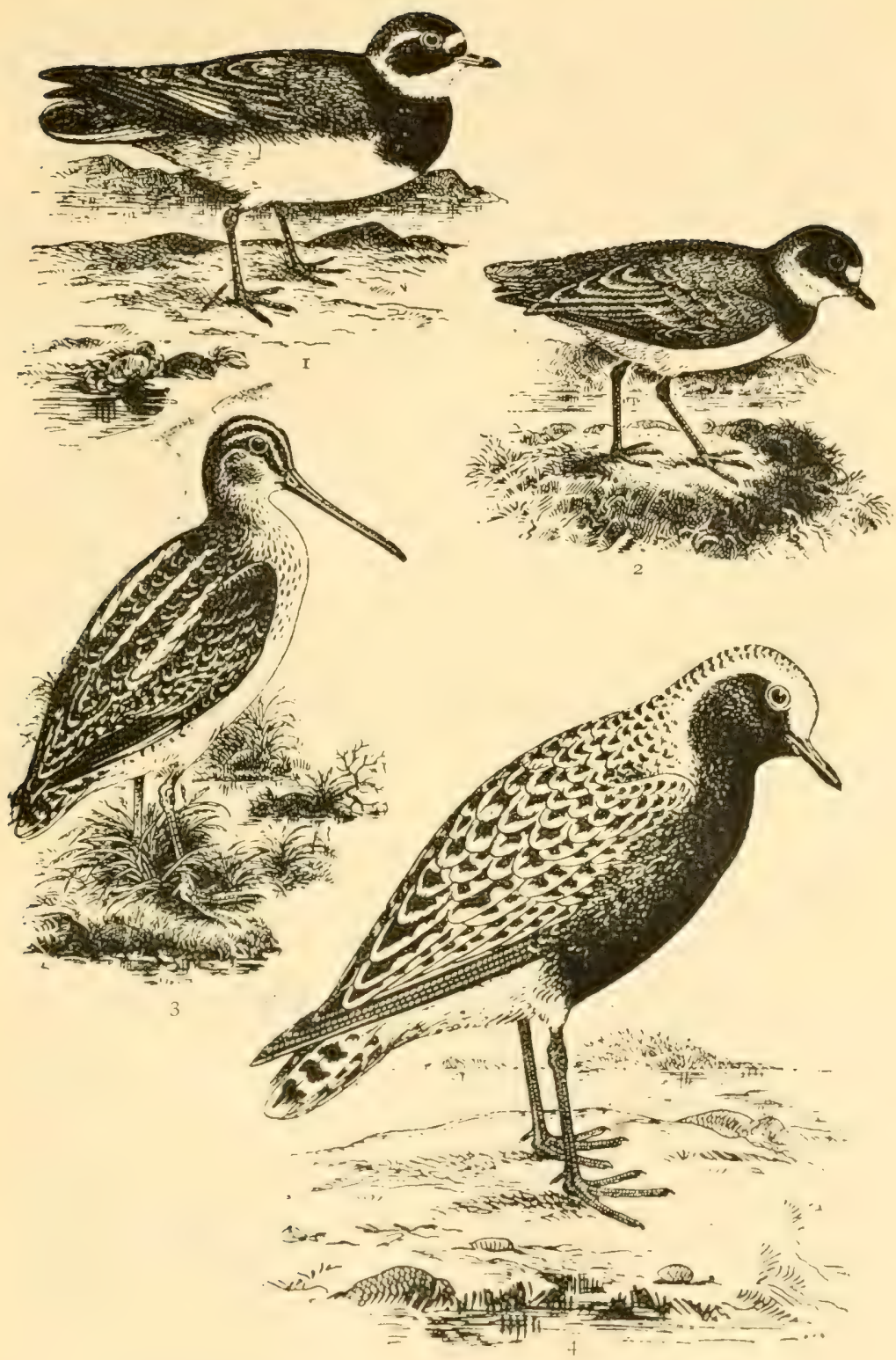

I. Greater Ringed Plover. 2. Lesser Ringed Plover. 3. Jack Snipe. 4. Grey Plover. 


\section{THE BIRD-LIFE OF LONDON}

The Stone Curlew (Edicnemus crepitans) is said formerly to have bred near Wantage, and occasionally to occur on migration in the Epping area, doubtless whilst on its way to breeding-places in the eastern. counties. It requires no further notice in the present work. 


\section{THE COMMON SANDPIPER}

\section{TOTANUS HYPOLEUCUS}

Local names in surrounding counties: "Summer Snipe."

Status in British Avifauna: A summer visitor, breeding on the moorlands from Cornwall northwards to the Shetlands, and equally widely dispersed in Ireland. It passes many other localities on migration, and odd individuals remain to winter on the south coast.

Radial Distribution within fifteen miles of $\mathrm{S}_{\mathrm{T}}$. Paul's: Although the Common Sandpiper is not known to breed anywhere in the Metropolitan area, it is a tolerably common visitor to various suitable places in many parts of it. It is one of those species that might be met with almost anywhere near to water during spring and autumn. It has been observed on the banks of the Thames, the Lea and the Brent within a few miles of the city. It is a regular visitor to the reservoirs at Barnes, and to the banks of the Thames between Putney and Kew, to the Penn Ponds in Richmond Park, and to brooks and pools in the Hounslow, Osterley, Harrow, Pinner, and Kingsbury districts. It may also be observed on migration at the Welsh Harp, at the Hampstead and Highgate ponds, at Barnet, Elstree, Waltham, Epping, and IVanstead, as well as in certain intervening localities. The same may be said of the various Kentish suburbs, whilst it is a tolerably regular visitor to many parts of Surrey within the Metropolitan area, from Croydon and Epsom northwards to localities already indicated.

The Common Sandpiper is most likely to be observed in the London area during the last half of April or eariy in May, on its passage north ; whilst it may be looked for on return migration from July onwards through August and September. It is a most engaging, active little bird, 


\section{THE BIRD-LIFE OF LONDON}

spending its time daintily tripping round the margin of pools or alongside rivers, streams, and canals. It is not very shy, and often allows an observer to watch its active movements within a few yards. It runs to and fro very quickly, pausing now and then and beating its tail up and down like a Wagtail. When alarmed it flies off uttering a shrill weet, and with long wings striking the surface settles again in a quieter spot. Like the Swallow it returns yearly to some particular place to breed, and passes the same spots each year on its annual migrations. In the love season the male utters a trilling note, often soaring whilst doing so. Its food consists of insects and larvæ, worms, crustaceans and other minute marine creatures, together with small ground fruits. It commences to breed in May, and eggs may be found during that month and June. The nest is a simple little affair on or near to the waterside, a hollow lined with vegetable fragments. The four eggs are pale buff, blotched and spotted with reddish brown of various shades and violet grey. The young and their parents keep in company, and as autumn advances small flocks assemble.

The adult Common Sandpiper has the general colour of the upper parts mouse-brown, with a greenish or bronze sheen, most of the small feathers having a dark central streak; the wing-coverts, innermost secondaries, scapulars, and upper tail-coverts are barred with darker brown; the greater wing-coverts are tipped with white, and the white bases to most of the brown quills form a wing-bar, very conspicuous during flight; the tail is light brown, with a green cast, the three outermost feathers on each side being barred with brownish black and white; the under parts are mostly white, suffused with brown on the sides of the breast, and streaked with darker brown on the fore-neck and breast. Bill dark brown, paler at the base; tarsi and toes pale olive; irides brown. Length 8 inches. The young in first 276 


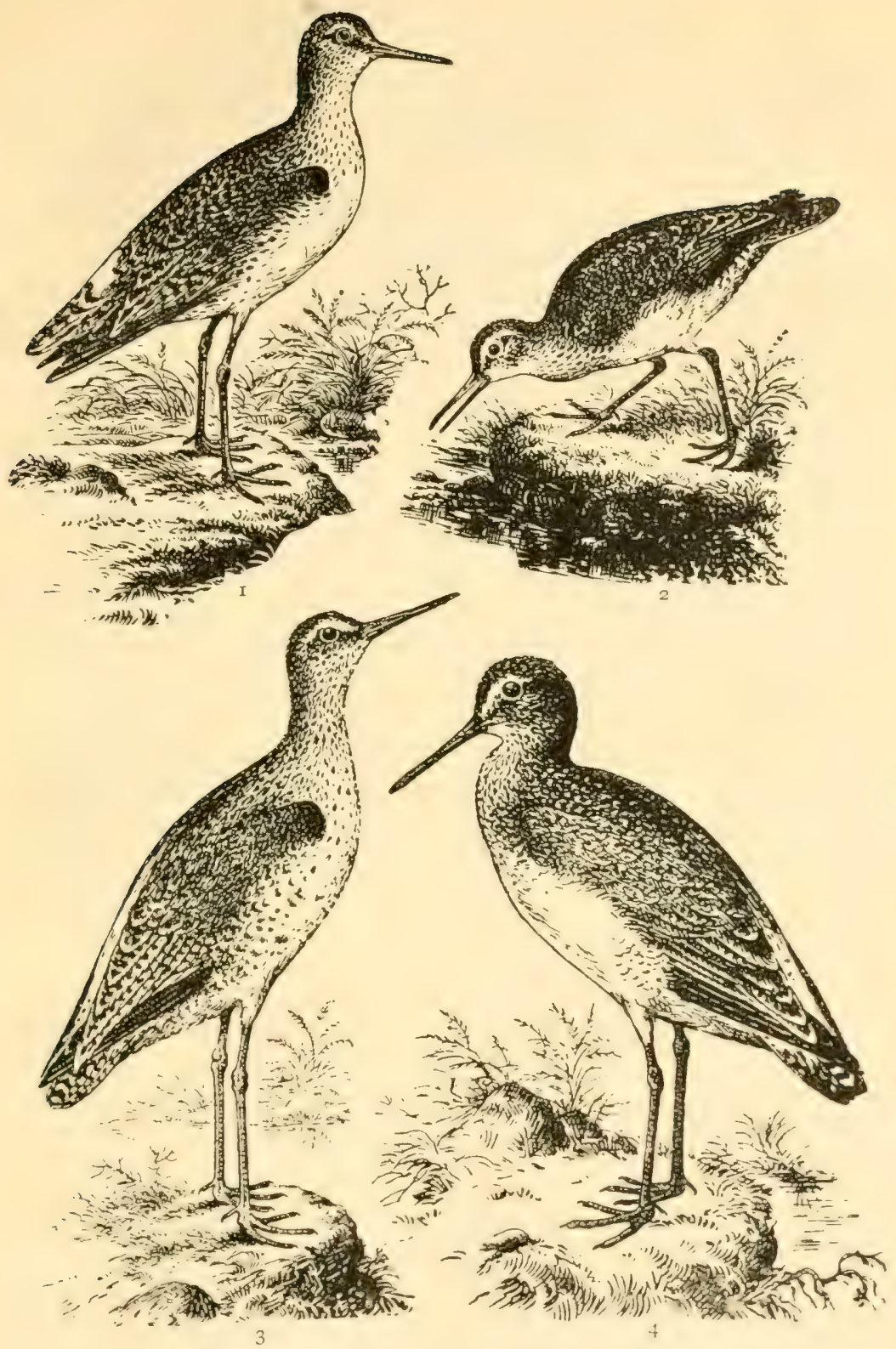

I. Wood Sardpiper. 2. Common Sandpiper. 3. Green Sandpiper.

4. Redshank. 



\section{THE COMMON SANDPIPER}

plumage resemble the adult, but the feathers of the upper parts are narrowly edged with buff and black. The young in down are pale grey, mottled with black on the upper parts.

One or two other Sandpipers demand passing notice here. The Wood Sandpiper (Totanus glareola) occurs rarely on passage, Kingsbury Reservoir and Epping being two localities. The Redshank (Totanus calidris) is another straggler to London during migration. It has been shot at Mitcham, frequently visits Kingsbury Reservoir and Hampton, in Middlesex, and is more or less regularly seen on the Essex saltings. The orange-red bill and legs serve readily to identify this little runner by the waterside. Lastly, we have the Green Sandpiper (Helodromas ocbropus) which occurs on passage across London chiefly in autumn, and so frequently in the Essex portion as to have several local names-"Will White" and "Black Snipe." It possibly occurs most regularly in Middlesex. It has a white rump and upper tail-coverts, very conspicuous during flight, and the axillaries are brown narrowly barred with white. This species is specially interesting because it lays its eggs in the deserted nest of a Thrush, Jay, Crow, or some other bird. 


\section{THE CURLEW \\ NUMENIUS ARQUATA}

Local names in surrounding counties: "Whitterick," "Old Harry" (Essex).

Status in British Avifauna: A widely distributed resident, changing its ground according to season: in summer frequenting the moors from Cornwall northwards to the Shetlands and those of Ireland; in winter resorting to the coasts, marshes, and lowlands. Its numbers are increased by migrants in autumn.

Radial Distribution within fifteen miles of St. PAUL's : It seems a little surprising that so large and so wary a bird as the Curlew should visit the Metropolitan area on migration. Undoubtedly the number of individuals that pay London a passing call is infinitesimal compared with the number that flies over the great city at so great an altitude as to escape notice. Cries from these migrating flocks are, however, often to be detected at night, especially in the quieter suburbs. The Curlew often visits Wimbledon on passage, and has been recorded from the banks of the Thames in various spots not very remote from the centrl area. I can also record it from Wembley and Kingsbury, from the Wclsh Harp, Elstree, and the neighbourhood of Pinner. In Essex, of course, the Curlew is a familiar bird in winter on the saltings, and it has been observed in the Wanstead and Epping districts. The same remarks apply to Kent, and there are records of the species from many localities within our limits.

There are few more shy and wary birds than the Curlew, and seldom indeed is one allowed to approach it within gunshot. It is one of those species that spends the greater part of the year on or near the coast, retiring in spring to moors and uplands to breed, returning with its young to 278 


\section{THE CURLEW}

the lower ground in autumn, and continuing thereon for the remainder of the time. It is most regular in its movements, passing from the saltings as the tide drives it away to higher ground inland, but returning almost to the minute as the ebbing water exposes its feeding-places. It runs and walks about in the usual manner of its kind, flies well and powerfully, and is noisy enough, especially when fired at or otherwise seriously alarmed. Its note is a rich, musical cur lee, ofttimes repeated, and during the breeding season it utters a bubbling cry resembling $w i w-i-w i w-i$-wiw, very quickly repeated. It is more or less gregarious during the non-breeding season, and in summer several pairs will nest on a comparatively small area of suitable ground. The food of the Curlew consists of worms, insects, and larvæ, small ground fruits and berries, sand-worms, molluscs and crustaceans. The return from the coast begins in March, and the eggs are laid in April and May. The nest is made upon the ground, either on the moors, rough lands, or upland fallows, and is little more than a hollow, scantily lined with a few bits of dry herbage, and in some cases the bare ground alone is used. The four eggs are pyriform in shape, olive-green or buff in ground colour, blotched and spotted with olive-brown and grey, and sometimes streaked with darker brown. But one brood is reared in the season.

The adult male Curlew has the general colour of the upper parts pale brown striped and mottled with dark brown; the rump is white; the shortest upper tailcoverts are white streaked with dark brown, the longest are very pale buffish brown barred with dark brown; the quills are dark brown barred with white; the wing coverts greyish white, with dark brown centres; the four central tail-feathers are pale brown, barred with dark brown, the four outer ones on either side white barred with dark brown; the under parts are white, suffused 


\section{THE BIRD-LIFE OF LONDON}

with brown on the neck and breast, which are streaked with dark brown, the flanks with sagittate markings of brown, the abdomen and under tail-coverts narrowly marked with the same. Bill long and arched, dark brown, paler at the base ; tarsi and toes lead-grey ; irides brown. Length $2 \mathrm{I}$ inches. The female has a longer bill, and the brown markings on the under parts are more numerous, and present also on the rump. The young in first plumage are more ochraceous, and the markings still more numerous. The young in down are greyish buff, mottled on the upper parts with dark brown. 


\section{THE COMMON WHIMBREL}

\section{NUMENIUS PHEOPUS}

Local names in surrounding counties: "Titterel," "May Bird," "Jack Curlew."

Status in British Avifauna: A regular and widely distributed visitor on spring and autumn migration, a few remaining to breed in the Hebrides and on the Orkneys and Shetlands, and small numbers remaining on the coasts to winter.

Radial Distribution within fifteen miles of $\mathrm{S}$ t. PAUL's: Very similar remarks apply to the Whimbrel as to the Curlew in the Metropolitan area. Great numbers of Whimbrels pass over London on migration in spring and autumn, and so far as the northern suburbs are concerned I can personally testify to the frequency of these journeying bands crossing the sky. For nights together they may be heard passing, uttering their unmistakable cries, especially in the vicinity of Harlesden, Kilburn, and Hampstead, and quite unsuspected by the majority of people below them. Records are to hand from all parts of the outlying suburbs of the occasional occurrence of the Whimbrel. A party of thirty birds were observed in the autumn of 1894 close to the grand stand on Epsom racecourse. The bird is well known on the Essex and Kentish saltings, and occasionally visits Wanstead, Epping, the Welsh Harp, Kingsbury, and the open grounds in the vicinity of the Metropolis.

The Whimbrel is so regular in its spring migrations that it is known in many localities as the "May Bird," its appearance on May Day being so unerring. It may be confidently expected in the London area any favourable night during the first half of that month. I have many records of these migrating bands of Whimbrels passing over the Metropolis always at night. First the well- 


\section{THE BIRD-LIFE OF LONDON}

known whistling note, uttered quickly in succession, sounds faintly from the sky; nearer and nearer the birds come, and the cries sound louder until they are more or less overhead for a few moments; then as gradually they decrease in loudness, and finally cease as the flock hurries northwards in impetuous haste, to be succeeded by another and another, like racing specials, announcing their passage across the sky. So far as my experience goes, it is rarely that any of these north-bound Whimbrels alight within the area of the Metropolis; the birds seem always too much in a hurry to linger by the way. The Arctic summer is short, the journey to the breeding-grounds is far, and a brood has safely to be reared and started on its way south before the polar world sinks into the lethargy of its long winter sleep. In autumn the conditions of the journey are vastly different. As soon as the young can fly even moderately well the southern passage begins, the birds gaining strength rapidly as they go, and the first individuals reach us in August. The strenuous haste of the spring flight is replaced by a leisurely desire to take things easily, and consequently many Whimbrels alight here and there by the way. During August and September the flocks recross the Metropolis, young birds preponderating, and it is mostly individuals of the latter that are tempted to descend and rest on the waterside or the wet, marshy spots of Greater London. These odd Whimbrels are by no means shy; they are young and inexperienced in the ways of man, and too often pay for their trustfulness with their lives. The Whimbrel is not known to breed anywhere on the mainland of the British Islands, but a few pairs nest on the Scotch islands. The habits of the bird are very similar to those of the Curlew; it nests in the same manner, and its four eggs are very similar, but much smaller.

The Whimbrel so closely resembles the Curlew in general coloration that it is widely known amongst 282 


\section{THE COMMON WHIMBREL}

gunners as a "Curlew Jack" or " Jack Curlew," presumably by the same line of reasoning that a small pike is called a "jack." Next to size the most important distinctions between the two species are that the crown is uniform dark brown, crossed by a pale mesial line and bordered by a well-marked stripe over each eye; the tail is also uniform brown barred with dark brown. The colours of the soft parts are similar. Length $\mathrm{I}_{5}$ inches. The young in first plumage are more densely mottled and spotted than the adult. The young in down are very similar to those of the Curlew. 


\section{THE WOODCOCK \\ SCOLOPAX RUSTICULA}

Local names in surrounding counties:

Status in British Avifauna: A local resident but most abundant during winter and the two seasons of migration.

Radial Distribution within fifteen miles of $\mathrm{S}$ t. PAUL's: The Woodcock was once much commoner within the Metropolitan area than it is now, and there are many places covered with streets and houses where it formerly had its haunts. Indeed, some of the present day parks were once famous retreats of the Woodcock. It is said occasionally to breed in the Windsor district, just beyond our limits. It has been known to do so in Epping Forest, and there are many quiet woodlands in the remoter suburbs where it might do so and be quite overlooked. I know of no locality, however, within the radius where the bird habitually nests. It is, therefore, as a winter visitor only that we can include the Woodcock amongst London's birds. It is found occasionally on the large suburban commons, Wimbledon, Tooting, Streatham, Wormwood Scrubbs, Hampstead, and so forth. Wembley Park was once a noted haunt of this species, and it still visits the Harrow and Kingsbury districts. Epping and Wanstead are other winter resorts; whilst many others are scattered about the Kentish and Surrey areas. It is rather erratic in its appearance, more numerous some years than others, and, I may add, has several times been killed in the streets of the Metropolis.

As a rule the only time the Woodcock is seen is when it is flushed. It is one of our most skulking birds, and as it is for the most part active at night its movements are very difficult to observe. Great numbers of Woodcock pass our islands in spring, and still greater numbers in autumn, 284 


\section{THE WOODCOCK}

on their way to and from their breeding-grounds in more northern lands. It is during this passage that the bird is chiefly noticed now near London, the indigenous individuals having been long exterminated. During the daytime it hides away under bushes or amongst rank vegetation in wet places. At dusk it comes out from its retreat and repairs to its feeding-places in the swamps and wet fields, where it probes into the soft ground for worms, which, with grubs and beetles, form its principal food. The Woodcock seldom flies far when flushed, and its movements in the air just as it rises are somewhat erratic. It soon settles down into a slower and even laboured flight, and often utters a croaking note as it takes wing. In the breeding season the male indulges in long flights in the morning and at night, passing to and fro along certain beats, uttering a curious harsh note, or a strange whistling cry. This is a love display, termed "roding," and should two rival males meet whilst it is being performed a combat frequently results. The Woodcock, except during actual migration, is not a very sociable bird, and when found in company it is usually the result of a common cause. The earliest eggs of the Woodcock are laid towards the end of March, but the majority in April, and again to a lesser extent in May. 'The nest is made on the ground, in some quiet spot in a wood or plantation, and is merely a hollow scantily lined with dead leaves and dry grass. The four eggs are not so pear-shaped as usual with the class to which the Woodcock belongs, and are pale buff, spotted and blotched somewhat sparingly with reddish brown and grey. The young when newly hatched are, it is said, often carried by the parents to the feeding-places, and the old birds will remove them if the nest is disturbed.

A very detailed description of the Woodcock is not necessary here, as the bird is too familiar to Londoners in every game-dealer's establishment during autumn and 


\section{THE BIRD-LIFE OF LONDON}

winter. The adult, with its long, straight bill and large eye, situated so far back in the head, is a very beautiful bird, having the general colour of the upper parts chestnut mottled and pencilled with black and grey. The black tail, marked with chestnut, with its row of silverlike spots at the tip on the under surface, is also a wellmarked feature. The under parts are buff barred with brown. Bill dull pink, shading into dark brown at the point ; tarsi and toes pale flesh-colour; irides dark brown. Length 15 inches. The female resembles the male in colour. The young in down are chestnut, marked with black and white above, buff below. 


\title{
THE COMMON SNIPE
}

\author{
GALLINAGO SCOLOPACINA
}

Local names in surrounding counties:

Status in British Avifauna: A common and widely distributed resident, most numerous in Scotland and Ireland, and more abundant in winter than in summer, its numbers being increased by migrants in autumn.

Radial Distribution within fifteen miles of $\mathrm{S}_{\mathrm{T}}$. Paul's : The Common Snipe is by no means uncommon during winter in many parts of Greater London. It has been known to breed at Wimbledon, and very probably does so at Epping. An example of this Snipe has been picked up in the Strand, but normally the bird is a visitor to the rural suburbs only. It is occasionally met with at Hampstead, and resorts to suitable haunts in the Enfield, Waltham, Barnet, Pinner, Harrow, Kingsbury, Hendon, Wembley, Twyford, and Osterley districts. On the Surrey side of the Thames it is well known in the vicinity of Mitcham, and occurred in large and exceptional numbers there during the winter of I894-95. The sewage-farm at that place is a favourite resort. A large influx of Snipe was remarked in the Norwood area during the winters of $\mathbf{1} 878-79, \mathbf{I} 880-8 \mathbf{I}$. In the more outlying suburbs the Common Snipe becomes of yet more frequent occurrence, and may fairly be said to haunt during winter suitable spots in all parts. Sewage-farms and marshy meadows and ditches, especially in the southern suburbs, are favourite resorts of this species.

Probably most of the Snipe found in the London area are migrants from more northern districts spending the winter in town. It may seem ridiculous, but there is a fair amount of Snipe-shooting to be got within the London suburbs by those gunners who are " in the know." The habits of this bird are little known to the ordinary 


\section{THE BIRD-LIFE OF LONDON}

observer of bird-life who confines his efforts to the species in his back garden or amongst his chimney-pots. It is a shy and skulking species, very rarely coming into view, hiding away amongst the tussocks of vegetation in wet places, most active during the night, and performing its migrations at that time. It leaves its winter retreats in London by March, and begins to return to them as early as August, its numbers increasing during September and October. The flight of this bird when first flushed is uneven and erratic, but soon becomes steadier, and is seldom far prolonged, unless during migration. The bird by no means uncommonly perches in trees, but this is during the mating season, when, like so many other of its kind, it seems to drop its skulking ways and to pay court to its mate in the air. The love flights and drumming of the Snipe during this period are very remarkable and interesting. The food of this Snipe consists chiefly of worms, grubs, insects, and small fresh-water molluscs. The bird is solitary in its habits in our country, but abroad more social tendencies are remarked. A good deal of this, however, may be due to the abundance of favourite food in a small area, and not to any social impulse. The Snipe's breeding season commences towards the end of March, and eggs are laid during April and May in our islands, later in more northern latitudes. The nest is a mere hollow in some dry spot in the marshes, lined with a few bits of dead herbage. The four eggs range from buff to olive in ground colour, blotched and spotted with rich dark brown, paler brown and grey, and occasionally streaked with blackish brown. But one brood is reared in the year.

The adult Snipe has the general colour of the upper parts black, with two broad lines of pale buff on each side of the back, formed by the margins to the scapulars and mantle; the rump and upper tail-coverts are rufous, barred with brownish black; the eye-stripes and a broad 288 


\section{THE COMMON SNIPE}

mesial line are pale buff; the quills are brown, the secondaries having broad tips of white; the tail is chestnut mottled with black, and the same colour at the base; the under parts are white suffused with buff, barred with chestnut and brown on the neck, breast, and flanks. Bill dark brown, paler at the base; tarsi and toes brown; irides brown. Length Io inches. The young in first plumage do not differ very much from their parents in general appearance, but the striping on the upper parts is not so pronounced. The young in down are dark chestnut, mottled with black and speckled with white on the upper parts. 


\section{THE JAGK SNIPE \\ LIMNOCRTPTES GALLINULA}

Local names in surrounding counties:

Status in British Avifauna : A common if somewhat locally distributed winter visitor.

Radial Distribution within fifteen miles of $\mathrm{S}_{\mathrm{T}}$. Paul's: 'The Jack Snipe is a tolerably well-known winter visitor to many parts of the Metropolitan area, perhaps more generally dispersed than the Common Snipe, because it is far less fastidious in its choice of a haunt. In the more immediate suburbs I find it of regular occurrence in the Norwood and Mitcham districts, and thence in various localities round Croydon. It is a regular winter visitor to the Middlesex portion of our radius from Bushey, northwards through Hounslow, Osterley, Southall, Wembley, Sudbury, Harrow, Pinner, Kingsbury, Enfield, and Potters Bar. Waltham, Epping, and Wanstead are the chief resorts in Essex in the immediate neighbourhood of London; whilst the Kentish Crays are noted haunts further south. I have flushed the Jack Snipe from allotment gardens between Harlesden and Willesden Green, and from marshy meadows near the Fever Hospital at Neasden. Indeed, I am inclined to think that this bird is not only commoner near the Metropolis than is generally supposed, but visits many localities where it has hitherto escaped the notice of persons competent to identify it.

A few Jack Snipes reach the London area as early as September, but the majority arrive in October and November. It is very remarkable not only how a very small patch of wet suitable ground will content this species, but how amazingly regular the same spot will be tenanted year after year, even if, as, unfortunately, too often happens, the birds are shot whilst occupying it. 290 
In its habits generally the bird closely resembles its larger ally the Common Snipe, but it is even more solitary. It migrates at night, and obtains most of its food under the cover of darkness. Rarely indeed is it observed active during the daytime, consequently its movements are difficult to watch. It is usually flushed quite unexpectedly at one's feet, darting off in an erratic, unsteady way at first, but finally settling down into a steadier flight, and seldom goes very far from its favourite haunt, returning thereto at the first possible opportunity. It is a very silent bird whilst with us, and seldom or never makes a sound when rising, not even the whirr of its wings being distinctive. Its food consists chiefly of worms, insects and larvæ, small seeds and tender shoots of vegetation during winter, but whilst absent from us crustaceans and mollusks are eaten. As many readers may be aware, the Jack Snipe does not breed anywhere in the British Islands, and but little has been recorded of its habits during the nesting season. It selects some dry spot in the Arctic swamps and makes a slight nest on the ground, a mere hollow lined with a few scraps of withered herbage. In this the female lays four large, handsome eggs, buff or olive in ground colour, blotched and spotted with rich brown, paler brown, and grey, and sometimes streaked here and there with darker brown. One brood only is reared in the season, the eggs being laid late in June. The southern migration commences soon after the young are strong enough to fly.

Although it is a very much smaller bird, the Jack Snipe closely resembles the Common Snipe in general appearance. If examined minutely the Jack Snipe will be found to have no pale stripe on the crown, the feathers of the mantle are purple, the inner webs of the scapulars are green, and the inner webs of the innermost secondaries are uniform brown; the tail is nearly uniform brown 


\section{THE BIRD-LIFE OF LONDON}

with darker shaft stripes and pale buff margins. Bill brown, paler at the base; tarsi and toes olive; irides brown. Length $7 \frac{x}{2}$ inches. The young in down are very similar to those of the Common Snipe. 


\section{THE BLACK-HEADED GULL}

\section{LARUS RIDIBUNDUS}

LOCAL names in surrounding counties:

Status in British Avifauna : A common and widely distributed resident, more local during the breeding season, and given to much wandering at other times.

Radial Distribution within fifteen miles of St. Paul's: The Black-headed Gull has become quite a feature in the bird-life of London during winter in the vicinity of the Thames from the Tower to Richmond, and especially between London Bridge and Westminster. Years ago the sight of a Gull in London was an event of exceptional interest; nowadays their visits to the Metropolis are so regular and in such abundance that they create no surprise and have become quite an interesting feature in the routine of the great city. The Thames, of course, is the great centre of their Metropolitan distribution, but a great many individuals resort to other localities, and the annual invasion of this species seems to be spreading to various outlying districts. 'This Gull frequents the ornamental waters in the urban parks, especially St. James's Park, Battersea Park, and in the grounds of Buckingham Palace. It may also be seen at Paddington on and about the canal basin, and near the open reach by the Harrow Road Bridge. I have also records from many other sheets of water, from some of the sewage-farms, and so forth. No indication of breeding has yet been noticed, nor do I think ever will be.

What I wrote about the Black-headed Gull in my book Open-air Studies in Bird-life I may be pardoned for quoting here: "They are voracious birds; food is a great inducement, and London crowds are very hospitable in these matters. Even the London errand-boy will share his humble dinner with the birds; whilst the 


\section{THE BIRD-LIFE OF LONDON}

aristocratic Western thoughtfully fills his pockets with food for them. Birds readily respond to encouragement of this kind. What impresses me most about these Gulls in London is their extraordinary tameness. It is the case of the Ring Doves over again. I have had much experience with the Black-headed Gull during winter, and have seen it congregate in thousands in various harbours, especially when sprats were being landed, yet there was always a certain amount of wariness, shyness that prevented the birds becoming very familiar. 'They would no more have taken a proffered sprat from my hand than they would even approach within arm's-length. Yet the novel and charming sight could be witnessed (and may now any winter) almost any day in London of these birds seizing scraps of food from the fingers, and exhibiting a tameness not excelled by the Sparrow itself."

These Gulls have now become such a recognised feature in the bird-life of the Metropolis that fish is regularly sold on the bridges for the passer-by to regale them; and so jealously are they regarded that even the London policeman, with all his other onerous duties, protects them from the mischievously inclined. I once saw a youth on Westminster Bridge secure a Gull that had trustfully perched on his arm, and was walking away with his prize when a policeman pushed through the crowd and sternly bade him release his captive. The poacher was within his rights, but sentiment became too strong, even for legality! 'The Black-headed Gull obtains, perhaps, as much of its food from the land as from the sea. It searches the fields for worms, insects, and larvæ; it captures small fish, crustaceans, and the many kinds of small animals to be found upon the beach. Not only so, but the bird may frequently be seen perched in trees near its breeding-places. Its note is a shrill krik or kur, modulated in many ways, especially during 294 

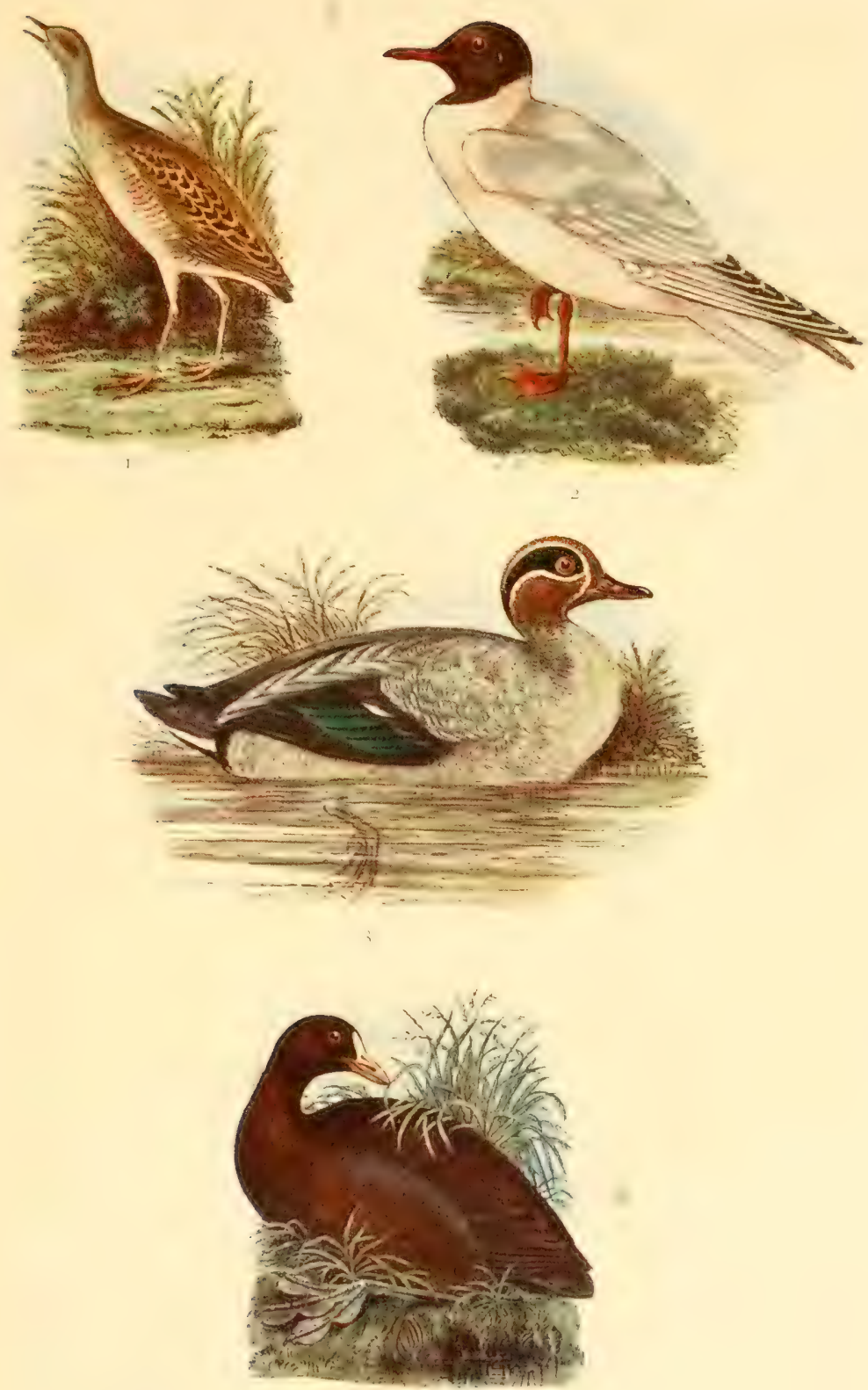

๘. Corn Crake, 2. Black-headed Gull. 3. Common Tenl. 4. Common Coot. 



\section{THE BLACK-HEADED GULL}

the pairing and nesting period. This Gull is eminently gregarious, not only during winter, but in summer. It begins to gather at the breeding-stations-reed-fringed pools and swampy meres-in March, and in April nestbuilding commences. The nests are mostly made on the wet ground amongst the tufts of rushes and sedge; but sometimes the low trees and bushes are occupied. In some cases the nests are little more than hollows in the ground or tufts of herbage; in others they are compactly made of reeds, flags and coarse grass, often increased in bulk to protect them from being washed away. The three, or more rarely four, eggs differ in colour to an astonishing extent, but are usually of some shade of brown or green in ground, marked in a variety of ways with brown and grey of many shades. In some places the birds are very carefully protected and the eggs systematically gathered for culinary purposes. At all times a gullery of this species is a remarkably pretty sight, but when the birds are disturbed the air becomes filled with clamouring hosts, the whole scene best being likened to a dense snowstorm, in which each flake is an anxious, protesting, fluttering, noisy bird. But one brood is reared, and as soon as the young are sufficiently matured the old wandering life along the coasts and tidal rivers is resumed.

The adult Black-headed Gull in winter plumage has the hind head marked a little with grey, a dark spot in front of the eye, another larger one on the ear-coverts, the mantle, scapulars, innermost secondaries, and wingcoverts delicate grey, the primaries white tipped with black and the longest margined with black; the remainder of the plumage white. Bill crimson; tarsi, toes, and webs crimson; irides brown. Length $16 \frac{x}{2}$ inches. Early in spring-even in January, but more usually in February and March-the adult assumes a dark smoke-brown hood or mask, the feathers changing colour 


\section{THE BIRD-LIFE OF LONDON}

for the most part, but to some slight extent being moulted (Ibis, I893, p. 440). The young in first plumage are brown above with buff margins, the tail is banded with black, and the bill, tarsi, and feet are much less vivid. The full adult plumage is not acquired for several years. The young in down are brown, marked on the upper parts with blackish brown. 


\section{OTHER GULLS AND TERNS}

\section{(LARINE) (STERNINA)}

Tine Black-headed Gull is par excellence the Gull of London and the Thames between bridges, but various other species of Gulls, and even Terns, casually visit the Metropolis, and require brief notice in a separate chapter. To the majority of observers the Gulls that visit London are all alike-they are "Seagulls," and that is quite sufficient for the ordinary "man in the street." There are, however, four other species of Gulls that pay casual visits to the Metropolis. I have on many occasions noticed Common Gulls (Larus canus) and Kittiwakes (Rissa tridactylus) among the crowds of Black-headed Gulls on the Thames. The latter, however, is, strictly speaking, an oceanic species, and seldom visits inland localities save in stormy weather. In the course of the present chapter I will mention how these two Gulls may be distinguished from the Black-headed Gull and from each other. The Kittiwake, amongst other places, has been observed at Lambeth, Battersea, and Putney, and I have personal records from Waterloo and Westminster Bridges. The next two species belong to the large type of Gulls that frequent the British Islands. Of these the Herring Gull (Larus argentatus) is a casual visitor to the Thames within the Metropolitan area, and frequently resorts to the fields, sewage-farms, and other open spots at some considerable distance from the river, or, indeed, from water of any kind. The second of these large species is the Lesser Black-backed Gull (Larus fuscus), which also casually visits London and its environs every winter. I have records of this Gull from Barnes, from Kingsbury, the Welsh Harp, and from rural districts as remote from the Thames as Harlesden and the meadows between Sudbury and Uxbridge. I believe it is a tolerably 


\section{THE BIRD-LIFE OF LONDON}

frequent visitor to Wanstead and other suitable parts of the Essex suburbs.

That Terns of several species visit the Metropolitan area during their annual migrations has long been known. It is impossible to name the exact species in a great many instances, observations, unless made by an expert or a person familiar with the various Terns that frequent the British seas during summer, being practically worthless in this respect. Both the Arctic Tern (Sterna arctica) and the Common Tern (Sterna birundo), there can be no doubt, occur casually within our limits not only in the vicinity of the river, but elsewhere at reservoirs and other large sheets of water. Their visits, however, are always fleeting ones, merely incidents of the migration journey the birds are engaged upon, and of transient interest only to the London observer. The Sandwich 'Tern (Sterna cantiaca), the largest of the species that visit the British Islands, has also, I believe, been recorded from the Metropolitan area. Lastly, allusion may be made to the Black 'Tern (Hydrocbelidon nigra), which evidently passes London's environs on migration at times. It has also been observed north of our limits at 'Tring Reservoirs, from which we may reasonably presume that Kingsbury, the Welsh Harp, and other lakes in that direction are visited too. 


\section{THE CORN CRAKE}

CREX PRATENSIS

Local names in surrounding counties :

Status in British Avifauna: A common and widely distributed summer visitor, varying considerably in numbers locally.

Radial Distribution within fifteen miles of $\mathrm{S}$ t. Paul's: There are still many spots from five to eight miles from the City where the rasping cry of the Corn Crake may be heard occasionally. The bird is somewhat erratic in its appearance, more abundant in some summers than others, and often deserting a locality for no apparent reason. Building operations in suburban London have done much to decrease its numbers. It is sometimes heard in Dulwich Park, on Wimbledon Common, in Wimbledon Park, and at Richmond and Kew Gardens. I have records of it from meadows in the Osterley, Hanwell, and Wembley districts; from Southall, Harrow, Pinner, Hendon, Finchley, Enfield, Waltham, Hampstead, Epping and Wanstead. In the most outlying districts it occurs more frequently, if locally, whilst it may visit many localities during its annual journeys when it is silent, and escape notice.

The harsh, discordant voice of the Corn Crake may still, I am heartily pleased to say, be heard in Greater London. There are yet many broad, goodly acres left within our limits to afford it cover, although these are being gradually absorbed by that destructive octopus the speculative builder. It reaches our southern counties towards the end of April, the return migration being undertaken in September and October. So far as Greater London is concerned the favourite retreats of this Crake are haymeadows and growing grain; upon its arrival it may frequently be heard in other spots, especially private 


\section{THE BIRD-LIFE OF LONDON}

parks and market-gardens, but as the summer advances its wanderings are much more curtailed. It is one of London's shyest and most seclusive birds, migrating by night, and very seldom being seen, its presence being almost invariably proclaimed by its persistently uttered call, a monotonous crake-crake easily imitated by drawing a knife-blade, or even the thumb-nail, smartly across a stout comb. I am of opinion that this curious note is uttered by the male only, and ceases to be heard in August. After the grass has been cut the Corn Crake may sometimes be watched walking about the fields in search of food, but at the least alarm it runs furtively to the nearest hedge for concealment. It seldom flies far, and takes wing only when absolutely compelled, rising with legs hanging down, and progressing in a slow and apparently laboured manner. Its food consists of worms, snails, and insects, together with small seeds and the tender shoots of various plants. This is obtained mostly at night, or at dusk and dawn. It pairs soon after reaching its summer haunts, and when this event is over the bird wanders little from the place where it has decided to remain and nest. In May the nest is made upon the ground, amongst the long grass in the meadows, a wellbuilt structure of dry grass and dead leaves, neatly lined with finer grass, much of it in a green state. Sometimes a couple of nests will be made in the same meadow at no great distance apart. The eight to a dozen eggs are pale buff or pale greenish blue in ground colour, spotted and blotched with reddish brown and grey. The young appear to be abandoned after they can fly, and the Corn Crake becomes for the most part a solitary bird. I have known it when caught to sham death in a most extraordinary manner.

The adult Corn Crake has the general colour of the upper parts brownish buff, each feather with a brownish black centre; the wings are reddish brown, brightest on 300 


\section{THE CORN CRAKE}

the coverts and darkest on the quills; there is a slate-grey stripe over the eye, and grey is the colour of the cheeks, throat, and breast, shading into nearly white on the abdomen and under tail-coverts and into dull chestnut on the flanks, which are marked with white. Bill pale brown; tarsi and toes pale brown; irides brown. Length nearly I inches. After the autumn moult the grey on the under parts is pale reddish brown, but the grey eye-stripe is retained, which is the case in young in first plumage, but with them the eye-stripe is buff. The young in down are uniform rich black

Two other Rails require passing notice here. The first of these is the SpotTed CRAKE (Crex porzani), a summer visitor to our islands, which occasionally wanders to Greater London in the course of its annual migrations. The bird may possibly breed in Bucks and Berks, is rare on passage in Surrey, an occasional visitor to Middlesex, and is sometimes met with at Epping and in the Hackney Marshes. The second species is the Water Rail (Rallus aquaticus), a resident in the British Islands, but subject to a good deal of local movement, according to season. It is said to be a scarce resident at Virginia Water, and the same remarks apply to the Thames Valley, the Colne, the Chess and the Kennet. In Middlesex it is both rare and local, chiefly being met with in winter, as it also is in Essex at Epping. 


\section{THE WA TER HEN \\ GALLINULA CHLOROPUS}

Local names in surrounding counties :

Status in British Avifauna: A common and widely distributed resident, found everywhere in suitable localities.

Radial Distribution within fifteen miles of St. Paul's: 'The Water Hen or Moor Hen is another of London's most familiar birds, made so by the fact of its frequenting almost every public pond and ornamental water in the Metropolis. It is common in Victoria Park, St. James's Park, Hyde Park, Kensington Gardens, Battersea Park, Regent's Park, and at Hampstead. Thence it may be met with, wherever there is water and a sufficiency of cover, in increasing numbers to the very utmost limits of the Metropolitan area. I have often flushed this species from ditches and cattle-ponds in the corners of fields, and it not unfrequently visits shrubberies, lawns, and private grounds at some considerable distance from water. It frequents many spots along the Thames, the Brent, the Lea, the Wandle, and the Beverley; there is scarcely a sewage-farm, a mill-pond, a reservoir, or even a watercress-bed that is not at least visited occasionally. At Wembley it frequents a small tributary of the Brent, and I have often seen it there walking sedately about the highway with almost as little concern as a barn-door fowl. It is equally familiar at Pinner and Uxbridge. In the more public localities the bird has become so familiar with man that it can scarcely be regarded as wild at all.

The Water Hen is nothing nearly so shy and retiring in its ways as the Corn Crake and seldom resents observation, unless threatened by actual harm. It may be watched walking sedately about the grass-land in measured 302 


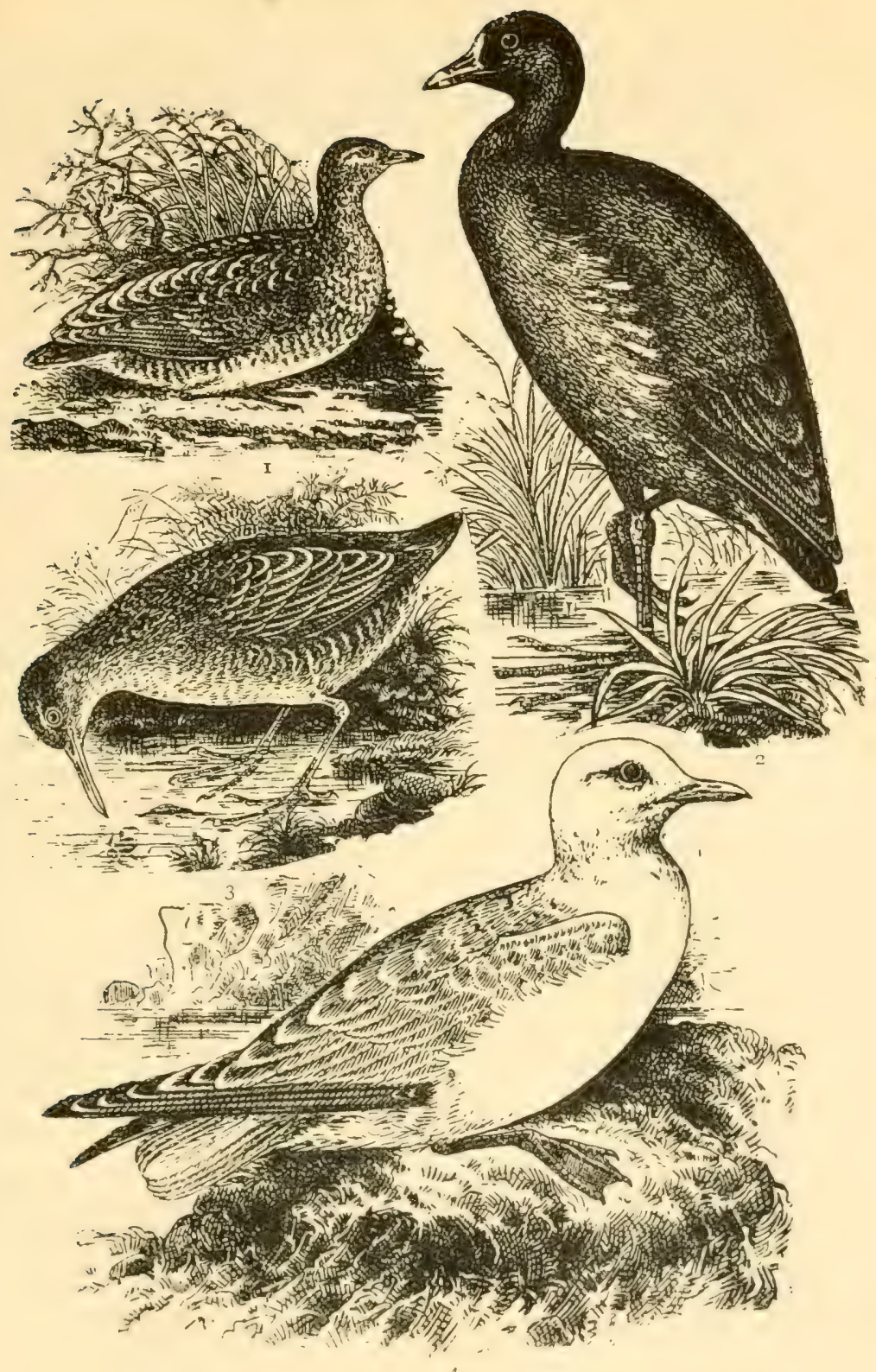

T. Spotted Crake 2. Water Hen. 3. Water Rail. 4. Kittiwake 



\section{THE WATER HEN}

steps, stopping every few moments daintily to pick up some food, and at intervals flicking its short tail. It is as much at home in the water as on land, and although its feet are not webbed it swims and dives with the greatest case. When swimming the peculiar nodding action of the head will be remarked; and it has a way of diving very suddenly when alarmed and going for a long distance under the surface, reappearing often amongst recds and rushes, in which it delights to conceal itself. It may also very frequently be seen in a bush or low tree. Only last winter I watched several of these birds in some whitethorn trees in Hyde Park greedily eating the haws. Its flight is not very powerful, nor usually much prolonged, but on occasion it will mount into the air at night and fly to and fro for a long time uttering its peculiar cry at intervals. This note resembles the syllables $k i k-i k-i k$, modulated into ker-r-r-k, and is heard chicfly at dusk or during the night. The food of the Water Hen is chiefly composed of worms, insects, larvæ, buds, seeds, and tender shoots of plants, together with various berries. In London it will eat almost anything, and in severe weather frequently visits houses for what chance fare it can find. It cannot exactly be regarded as gregarious, but it is certainly social, and I have frequently seen a dozen or more feeding on one small lawn after a shower. It is an early breeder and nests may be noticed in the London parks in March long before the flags and other water-plants are high enough to conceal them. Nesting becomes more general, however, in April, and, as several broods are often reared in the season, is continued into August. The big, untidy nest is made amongst reeds, flags, rushes, and other aquatic plants, or under brambles and thorn-bushes where the branches hang over or into the water. Sometimes it is made quite a floating structure, anchored to the rushes some distance from land. It is often a great heap of rotten aquatic herbage massed 


\section{THE BIRD-LIFE OF LONDON}

together, the shallow hollow containing the eggs being lined with drier material. Some nests are much smaller, especially when made on dry land. The six to a dozen eggs are pale buff, spotted and blotched with reddish brown and grey. The chicks take to the water almost directly they are hatched, and in the London area especially too often become the prey of rats and prowling cats.

The adult Water Hen has the general colour of the upper parts dark olive-brown, shading into dark grey on the head and neck, and into brown on the wings; the outside web of the first primary is white; the under parts are slate-grey, shading into brown on the flanks, which are striped with white, and the abdomen is mottled with white; the longest under tail-coverts are white, the shorter ones black. Bill and frontal shield scarlet, the bill shading into pale yellow at the tip; tarsi and toes green; irides brown. Length $\mathrm{I} 3$ inches. In autumn there is more white mixed amongst the plumage of the under parts. The young in first plumage are browner, the slate-grey on the head and neck are replaced by dark olive, and the under parts are brown, the white mottling being strongly pronounced. The young in down are uniform rich black. 


\section{THE COO'T \\ FULICA ATRA}

Local names in surrounding counties: "Bald Coot." Status in British Avifauna: A common and widely, if somewhat locally, distributed resident, given to some local migration.

Radial Distribution within fifteen miles of $\mathrm{S}_{\text {t. }}$ Paul's: The Coot is much rarer and more local than the Water Hen in the Metropolitan area, and although a casual visitor to many localities therein is usually a permanent resident only in such spots where it is carefully protected. It is known as an occasional visitor to the ornamental waters in the grounds of the Crystal Palace, to the lake in Wimbledon Park, and to the vicinity of Dulwich. It frequents the Penn Ponds in Richmond Park, the lake at Osterley, Ruislip Reservoir, occasionally resorts to Wembley, is found at Kingsbury and Elstree, and breeds in Wanstead Park. Coots are often seen here and there on the Thames, the Brent, and the Lea, but never frequent such small pools as content the Water Hen. I have records of this species from the Welsh Harp in winter, and there must be many private waters which it frequents at the same season, if it is not found on them at other times. Beyond our limits the Coot is common at Tring Reservoirs. A few Coots also frequent (and breed there) a small, stagnant sheet of water close to the bridge over the Grand Junction Canal at Northolt, and also some ponds in private grounds near that place on the Sudbury side.

The Coot is not so adaptive as the Water Hen, is a much shyer bird, and requires a larger expanse of water. It loves large, open sheets of water where there is ample space to retire from danger far from the banks, and is always much more wary than its ally. It closely resembles 


\section{THE BIRD-LIFE OF LONDON}

the Water Hen in its habits, being equally at case on the land as in the water. It may be watched walking about the grass in the usual Rail-like way, picking here and there as it goes. It is equally at home in trees, and often visits them to roost. It is not, however, so nocturnal, feeding chiefly during the daytime. When swimming it has the same peculiar hobbing of the head and is quite as expert a diver as its smaller relative, often going for a long distance under the surface to elude danger. It seldom flies far, except when compelled, and when rising somewhat heavily allows its legs to dangle down for some moments. It has the same habit of flying about at night, its whereabouts being indicated from time to time by its clear, far-sounding note of $k \ddot{o}$. The Coot is a social bird during summer, and in autumn and winter often assembles in large flocks, but these big gatherings are usually on salt water, to which many of the birds resort at that season. The food of this species is largely composed of grass, buds, leaves, berries, and the tender shoots of various plants; to this fare is added grain, insects, grubs, snails, worms, and small fishes. The bird may often be seen browsing like a Goose. The breeding season commences in April, and most of the eggs for the first broods are laid in May, for later ones in July. The nest, often a floating structure, is made amongst aquatic vegetation, and is a big heap of rotten plants, at the top of which a shallow cavity is lined with finer and drier material of a similar character. The six to a dozen eggs are pale buff or stone-colour, sprinkled and dusted with blackish brown and grey. The young chicks take to the water soon after they are hatched, where they are fed and tended by the parents. Many pairs often nest on the same sheet of water.

The adult Coot has the general colour of the plumage an almost uniform lead-grey, becoming almost black on the head, neck, and under tail-coverts; the quills are 306 


\section{THE COOT}

brown, the secondaries being tipped with white, forming a bar across the wings. Bill pale pink, shading into white at the tip; frontal shield white; tarsi and lobed toes olive, the tarsal joint orange; irides crimson. Length I $4 \frac{\pi}{2}$ inches. The young in first plumage have the upper parts olive-brown and the under parts nearly white. 'The young in down are rich black, with a few white tips to some of the filaments. 


\section{THE HERON \\ ARDEA CINEREA}

LOCAL names in surrounding counties: "Frank," "Frank Hern" (Essex); "Hernshaw."

Status in British Avifauna: A widely distributed yet local resident.

Radial Distribution within fifteen miles of St. Paul's: There are few other cities in the British Islands that can claim the Heron as a breeding species in their immediate suburbs. In the Metropolitan area there are at least three flourishing heronries within eleven miles of the Cathedral, one of them within seven miles. The latter is at Wanstead, and is the most extensive of the three. This is within reach of a tram-ride from the city. There is another and a smaller colony in the Sidmouth Plantation in Richmond Park, little more than a 'bus-ride from the Bank of England; whilst a third colony exists in Osterley Park, an area of easy access from all parts of the Metropolis. Taking these facts into consideration, the appearance of the Heron in some of the more central districts is by no means remarkable. The bird is occasionally seen in Battersea Park, and regularly feeds in Kensington Gardens and down the river to Hammersmith and Barnes. It also frequents many of the brooks, reservoirs, and ornamental waters in suburban localities right round the Metropolis. On occasion it may be scen in powerful swinging flight, crossing over the vast City from one favourite haunt to another, usually towards evening.

Strange as the fact may seem, there are many country places where the Heron is seldom seen, and still more where it is never known to breed; yet the bird is fairly common within the Metropolitan area, and may be watched at its nest within half an hour's ride of town 308 

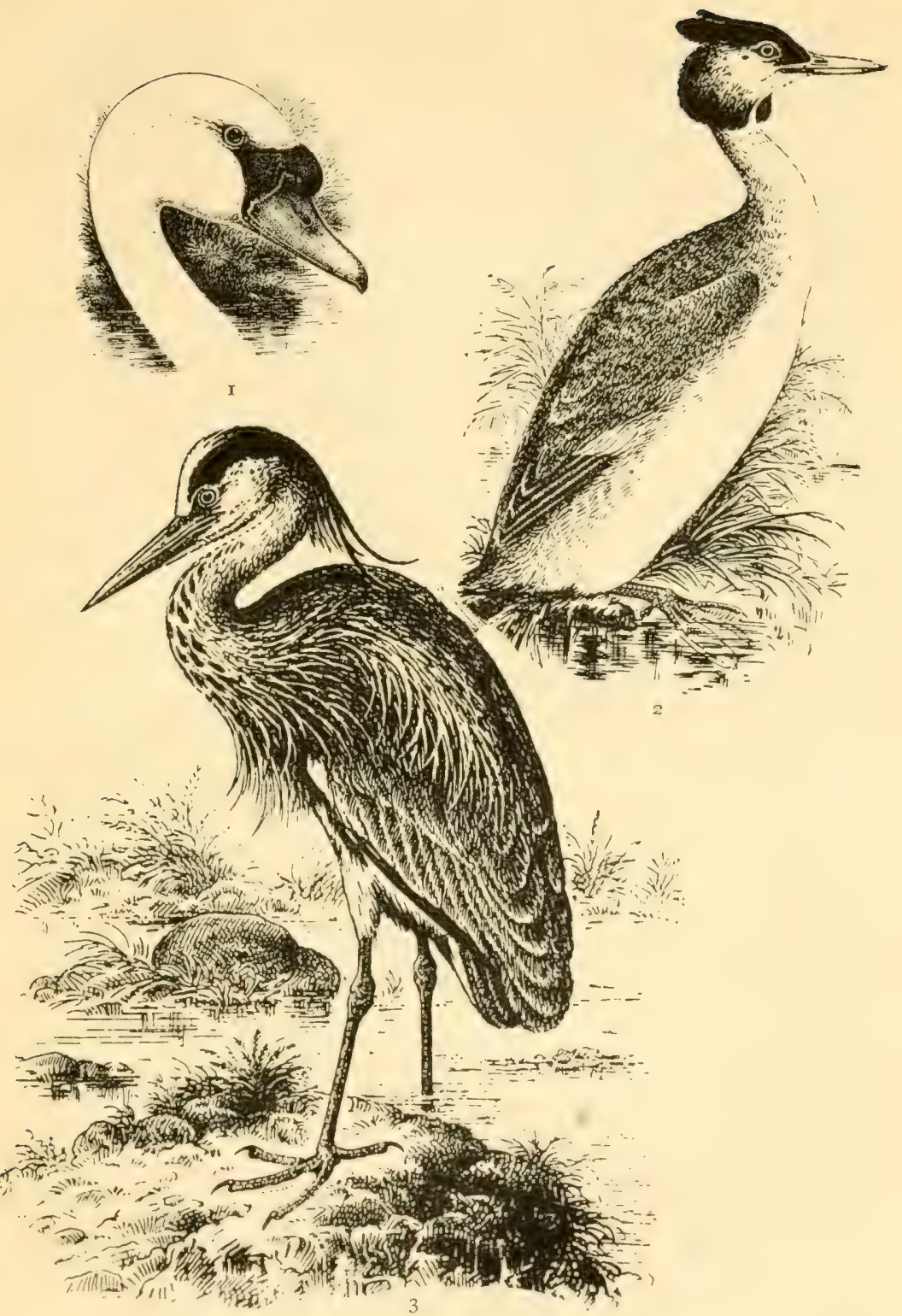

I. Mute Swan. 2. Great-crested Grebe. 3. Common Heron 



\section{THE HERON}

itself. This is at Richmond Park; whilst there are some forty nests at Wanstead. Although the Heron breeds in societies like Rooks, the bird is by no means so gregarious, and often wanders off alone to feed by itself. In some localities, however, several may be seen fishing in company. The sight of this big bird winging its stately way across the sky so near to the great city is a cherished delight to the student of London bird-life, and one may hope that the Heron will eventually spread to other parts of the vast Metropolis. The Heron seeks most of its food by the waterside or in swampy places. Here it may be seen standing motionless and watchful waiting to pounce upon some small fish or frog, or walking sedately about in quest of some lizard or small. animal. It is one of the wariest of our native birds, conscious that its large size attracts notice, and hurries off the moment danger is detected, unfolding its broad wings and rising with mighty sweeps, its long legs raised up in a line with the head, which is held well between the shoulders. It often flies far to feed, and during the nesting season is a familiar object in the sky, passing to and from its nest. Its loud, trumpet-like call is heard most frequently during flight; but at the nest especially, where the birds are somewhat quarrelsome, a series of grunting croaks may often be heard. The Heron begins nesting near London almost as soon as the Rook, and the eggs are laid during March and April. The same woods are used year by year, and the nests are built in close proximity. The nest is a huge massed platform of sticks, often the accumulation of years, mixed with turf and moss as a sort of lining in some cases but not in all. The three to five eggs are greenish blue. When the trees are approached the big birds rise fluttering through the branches, and at a great height sail to and fro watching the fate of their homes. At Richmond the Herons may be watched standing on their nests or perched on the 


\section{THE BIRD-LIFE OF LONDON}

branches, from time to time flying backwards and forwards, whilst every now and then birds come up from the river or depart in quest of food.

The adult Heron has a broad black stripe on each side of the head, reaching on to the nape, where it forms a long, drooping crest of several narrow plumes; a series of black spots extends down the fore neck, extending into a broad black stripe on each side of the breast and abdomen ; the primaries, secondaries and primary coverts are greyish black; the remaining wing-coverts, the flanks, rump, upper tail-coverts, tail, scapulars, and mantle are delicate slate-grey; the lower back is of the same colour, the feathers white at the tip and prolonged into a plume, as are the feathers on the lower neck; the remainder of the plumage is white. Bill and naked skin at the base yellow; tarsi and toes brown; irides yellow. Length 36 inches. The female has not quite so long a crest as the male. In the young in first plumage the crest is very short, the upper parts are suffused with brown, the elongated plumes on the back and neck are wanting, and the black on the breast and abdomen is replaced by greyish brown. 


\section{THE GREAT-CRESTED GREBE

\author{
PODICEPS CRISTATUS
}

Local names in surrounding counties: "Loon" (Essex).

Status in British Avifauna: A somewhat scarce and local resident, commonest in England and Wales, rare in Ireland and the south of Scotland; more widely dispersed in winter than in summer, and at the former season frequenting the coasts.

Radial Distribution within fifteen miles of $\mathrm{S}$ t. PaUl's : 'The Great-crested Grebe seems to be increasing as a breeding species in the Metropolitan area. The nearest breeding haunt to the city known to me is the lake in Wimbledon Park, some seven miles from the Cathedral. Another nesting-place is at the Penn Ponds in Richmond Park, open to every observer; whilst a third is the lake in Osterley Park, on the nine-mile radius. During winter this Grebe casually wanders to waters much nearer the City, and is then seen in localities remote from its breeding resorts. It has been seen on the 'Thames between Charing Cross and Waterloo Bridges, and at the reservoirs at Barnes. It appears to be rarer in the east than in the west and south. I have a record from Kingsbury Reservoir in winter, and I believe the bird occasionally visits Elstree and the Welsh Harp. Records of the species from Kent are meagre, and much concerning its Metropolitan distribution requires investigation.

The Great-crested Grebe, like the Coot, prefers a large open sheet of water, where it has plenty of room to retire from the banks when threatened by danger. Although it can fly well enough when necessary, this bird lives almost entirely in the water, where its diving powers are amazing. It seldom visits the land, and here its movements are awkward and shuffling. $\Lambda t$ some of its London haunts the bird may be watched gracefully 


\section{THE BIRD-LIFE OF LONDON}

floating or swimming to and fro far away from the banks near the centre of the pool. As if conscious of its safety, it may be seen picking insects from the water or from the stems of the aquatic plants, and at intervals diving beneath the surface. It might almost be said to fly to and fro through the water, so deft are its movements. If a pair of Grebes are in company one only dives as a rule, the other remaining on the surface as if on the look-out; but sometimes both disappear together, and indulge in aquatic gambols, chasing each other hither and thither in sportive play. During the nesting season the female may be noticed diving again and again and bringing bunches of weed from the bottom to add to her nest. The male sometimes joins her in her dive, but seldom brings up any material. The food of this Grebe consists of small fishes, aquatic insects, frogs, molluscs, seeds, and tender buds and shoots of plants. Its note is a shrill kik or kek, and during the breeding season both birds utter a harsh, grunting cry. It breeds in April, May, and June, and probably pairs for life, nesting regularly in the same spots. It is to a great extent gregarious even during summer, and in places where it is at all common numbers of nests are built in one vicinity. 'The big nest, composed of decaying aquatic vegetation, with a shallow cavity at the top, lined wth similar but finer material, is as often as not a floating raft moored to the flags and reeds. Other nests have their foundation at the bottom of shallower water. They are added to at intervals to resist the inroads of the lapping waves. The three to five eggs are white and chalky, but the interior of the shell is green, and very elliptical in form. When disturbed the sitting bird is careful to cover her eggs with bits of wet weed before leaving them. The young chicks are equally at home in the water.

The adult male Great-crested Grebe has the general colour of the upper parts below the neck greyish brown, 3 I 2 


\section{THE GREAT-CRESTED GREBE}

each feather with a pale brown margin; the lesser wingcoverts form a white band along the carpal region; the secondaries and the under parts generally are white, shading into brown on the flanks, which are further mottled with chestnut; the forehead, crown, hind neck, and crest of two "horns" dark brown; the lores and throat are white, shading into the chestnut of the bushy nuptial tippet, which is margined with black. Bill red; tarsi and lobed toes olive-green ; irides crimson. Length 20 inches. The female has the tippet and "horns" less developed. After the autumn moult these ornaments are lost by both sexes. The young in first plumage closely resemble this winter dress of the adult. The young in down have the head, neck, and under parts white, the rest of the upper parts brown ; there are black stripes on the upper parts, and the breast and the cheeks are grey. There are also two black stripes across the bill. 


\section{THE LITTLE GREBE}

PODICEPS MINOR

Local names in surrounding counties: "Dobchick" (Essex).

Status in British Avifauna: A common and widely distributed resident.

Radial Distribution within fifteen miles of St. Paul's: The Little Grebe breeds commonly, and in a perfectly wild state, about a mile and a half from the Cathedral, in St. James's Park. Four or five pairs frequent this locality. I believe the bird also nests in Battersea Park, at Kew, and possibly in Regent's Park. I have records of this Grebe from the Serpentine, and from one or two reservoirs at no great distance from the central districts. In the more rural and secluded suburbs the Little Grebe becomes more widely dispersed, and I have so many records of its presence in all directions that an enumeration of them is scarcely necessary. On the other hand, the bird appears to be somewhat capricious in selecting its haunts, and I have known it to frequent certain spots right through the winter, yet desert them in spring, although apparently suitable in every way for nesting purposes. The smallest pools and drains will often afford this Grebe a refuge, and in winter it is given to much wandering. It occurs in some numbers on the ponds about Northolt and Uxbridge, the latter, however, being just without our limits, but within a few minutes' ride or walk of them.

The habits and movements of the Little Grebe may be readily observed within a few minutes' walk of the busy Strand, in St. James's Park. The bird is nothing nearly so shy and wary as the preceding species, and will fearlessly swim about the ornamental water there quite close to the bank. It is just as expert a diver as its larger ally, and its 314 


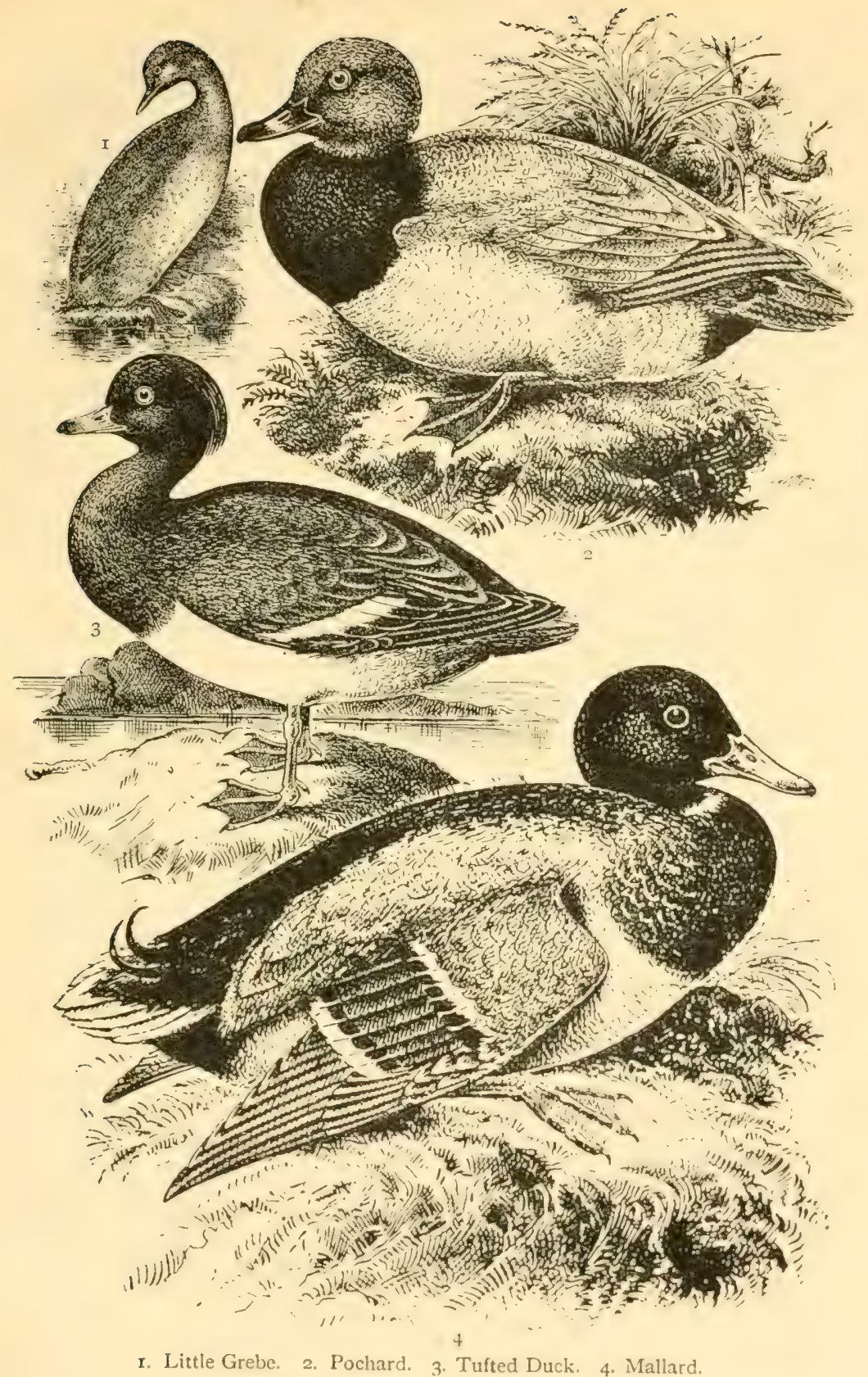





\section{THE LITTLE GREBE}

movements on the land are much more graceful. It seldom flies far, although able enough to make a prolonged journey in the air. Its note is a shrill ueet. If alarmed its usual method of escape is to dive with the quickness of a flash, rising again many yards away, and diving again and again if pursued. Most of its food is obtained from the water, and consists of tiny fish, tadpoles, insects, molluscs, and the tender shoots and buds of plants. I have often remarked that Little Grebes in the remoter suburban areas are very much more wary than those individuals frequenting the parks. In some cases at least this bird gathers into flocks for the winter, but in summer it is a solitary species, each pair keeping to a particular haunt and resenting intrusion. The breeding season commences in March, and, as several broods are reared, is usually prolonged into July or August. The nest, more or less floating, and built up from the bottom of the water, is concealed amongst reeds and rushes, but sometimes rests on the marshy ground of the banks, hidden by overhanging brambles and other vegetation. It is a heaped-up mass of rotten vegetation of many kinds, trodden and matted together, with a small cavity at the top rather more neatly finished. The four to six eggs are lustreless white, and soon become stained by the wet nest and feet of the parents. The old bird covers them with marvellous celerity when disturbed, and before leaving them. The chicks take to the water at once, and are often carried under the parent's wings as she dives with them to a place of safety.

The adult male Little Grebe in breeding plumage has the general colour of the upper parts brownish black; the wings are brown, the secondaries marked with white; the chin, upper throat, and space below the eye are black; the lower throat, the checks, and the front of the neck are chestnut, the remaining under parts brownish black, except the under surface of the wing, which is 


\section{THE BIRD-LIFE OF LONDON}

white. Bill black, yellow at the tip, and light green round the gape; tarsi and lobed toes olive-green, palest on the webs; irides brown. Length $8 \frac{x}{2}$ inches. The female is a trifle smaller and paler in general colour. In winter plumage the upper parts are brown, darkest on the head, and the under parts are mostly white. The young in first plumage resemble the adults in winter dress, and the young in down have the head, neck, and upper parts black striped with chestnut, and the under parts white including a $\mathbf{V}$-shaped mark on the throat. 


\section{THE MALLARD}

\section{ANAS BOSCHAS}

Local names in surrounding counties:

Status in British Avifauna: A common and widely distributed resident, increased in numbers in autumn by migrants, and given to much internal wandering during the non-breeding season.

Radial Distribution within fifteen miles of $\mathrm{S}$ t. Paul's: Although the Mallard is of most frequent occurrence during winter there are various places comparatively close to the City where it habitually nests. It may rightly be classed as a local resident within the Metropolitan area, its nearest breeding-places being probably Hyde Park and at Wanstead, Epping, and Richmond. In the latter locality a few pairs nest regularly in Richmond Park. I have been informed that this Duck also breeds in Osterley Park, about the Wembley district, at Kingsbury, and in the vicinity of Pinner, Harrow, and Elstree, but have no personal confirmation of the fact to offer. I have evidence of its doing so in the Epsom, Banstead, and Croydon areas, as well as in the Kentish Crays. During winter the Mallard pays more or less fleeting visits to many of the waters within our limits, in some cases in considerable numbers, and at that season wild birds are frequently tempted to join their half-captive congeners on some of the ornamental waters in the urban parks. The Welsh Harp and the Highgate and Hampstead ponds used years ago to be frequented by this species, as I know from personal experience.

There are many semi-wild Mallards on the ornamental waters of the Metropolis, so that the bird should be familiar enough to most people. It is by far the commonest of the British Ducks, and may often be flushed from quite small pools and streams. Indeed, it always 


\section{THE BIRD-LIFE OF LONDON}

seems to prefer shallow waters, where it can paddle about and search the mud and vegetation near the bank. It never dives, but often turns almost perpendicular, with little more than its tail above the surface, and with rapidly moving legs and feet to preserve its position searches the bottom for food. It swims well too, and flies with great speed and strength, the wings beating rapidly with a whistling noise, or sometimes held arched and rigid as the bird skims along for some distance. I have said that it never dives, in the ordinary acceptance of the term, but it may often be seen flying under the water with a great splashing in chase of its mate or companions in a sort of frolic. It is wary enough in a wild state, and most difficult to approach, suspicious of everything. In the vicinity of London it is generally met with in pairs here and there, but in winter it often assembles into large flocks, which in some cases consort with other species. It is almost an omnivorous bird, feeding on vegetable substances, grain of all kinds, and its animal diet may be said to range from an insect to a fish. It is a gluttonous eater, and often traverses long distances in quest of food, which is mostly sought during night-time. The familiar quack of this Duck needs no description, but the bird also utters many other sounds which I find it impossible to express in writing. The Mallard breeds early, the eggs being laid in March or April. The bird pairs for life, and the nest is generally made on the ground in some quiet spot, very often far from water, amongst grain, bracken, or heath. Sometimes it is made in a hole in a tree, amongst ivy-as I once knew in Hyde Park-or even in the old nest of a Rook or a Crow. When on the ground it is a mere hollow lined with fern-fronds, bits of heath, and dry grass, but as the eggs are deposited a warm, thick bed of down is added. 'The eggs, from eight to sixteen, are buffish green or greenish buff. The drake takes no share in rearing the brood, nor is he ever seen near the nest. The young are 3 I 8 
tended most carefully by the duck and she is most courageous in shielding them from harm.

I need not take up space by describing this species in detail, as it is only too well known, but mention may be made of the curious eclipse which the drake enters whilst moulting his flight feathers. He then assumes a dress very similar to that of the female, probably from motives of protection, when he is unable to fly, and when his ordinary gay attire would more readily betray him to enemies. The purple speculum in the wing is a diagnostic character of the Mallard. Length about 24 inches. 


\section{THE COMMON TEAL}

NETTION CRECCA

LOCAL names in surrounding counties:

Status in British Avifauna: A common and widely distributed resident in all suitable localities, especially in the north; largely increased in numbers in autumn by migrants, and subject to much wandering during the non-breeding season.

Radial Distribution within fifteen miles of $\mathrm{S}_{\mathrm{T}}$. Paul's: The Teal has been recorded as breeding in Richmond Park, but possibly the fact is an exceptional one, as competent observers fail even to record the bird even as a casual visitor to that locality. I have no evidence to show that the Teal breeds anywhere within the Metropolitan area. It may do so in the more remote and rural suburbs, and I should like to be acquainted with any fact to confirm it. At present I can only say that the Teal is an occasional visitor to many waters within our radius during winter, and that it possibly resorts to some of the more centrally situated lakes to fraternise with the half-wild Ducks that frequent them. I have records of this bird from Osterley and Kingsbury and I believe examples have frequently been obtained in the Harrow, Wembley, and Epping districts. It is also known as a winter visitor to Wanstead, and there are certain mill-dams in Surrey where it is to be found every winter.

Many Teal reach our islands in September, but larger numbers do so in October. During winter it is more or less gregarious, associating also with other species. It is partial to ponds and lakes where the banks afford plenty of cover, and prefers fresh water to the coast. Its flight is rapid and powerful; it swims well and buoyantly, but it does not dive, obtaining its food in the shallows or 320 


\section{THE COMMON TEAL}

on the banks. T'his is sought for by day and by night in localities where it is not molested, but in some places where persecution teaches it wariness it feeds during darkness alone. It will then be found to pass the day on large, open sheets of water well out from shore, retiring at dusk to the smaller pools and marshes to feed, passing certain routes with much regularity. It searches for food in much the same manner as the Mallard, and its diet is almost as varied. Its alarm-note is a low quack, and the call-note a harsh cr-r-rik. It breeds in May, on the margin of some marshy pond, and probably pairs for life. The nest is made on the ground, sheltered by brambles, or concealed amongst heath, sedges, and coarse grass, and is made of dry grass and scraps of withered herbage, warmly lined with down from the duck's body. The eggs are eight or ten, creamy white or buffish white, sometimes with a greenish tinge.

The Teal is so well known that a long description may be dispensed with. I may, however, give the diagnostic characters which will enable the student to identify this species in any plumage. The bill is shorter than the head, and does not taper towards the tip; there is no fringe of soft membrane near the tip of the apical portion; the central tail-feathers are acuminate, and extend slightly beyond the outer ones; whilst the scapulars and tertials are longer than in a Widgeon. The head is partly metallic green, the top of the head chestnut, like the cheeks; the lower scapulars are white, edged with white on the outer web (male); the alar speculum is black, and the wing under 7 inches in length (female). Length I $4^{\frac{I}{2}}$ inches. 


\section{THE WIGEON}

\section{MARECA PENELOPE}

Local names in surrounding counties:

Status in British Avifauna : Common winter visitor, most abundant in autumn, a few breeding in Scotland and Ireland.

Radial Distribution within fifteen miles of $\mathrm{S}$ t. PAUl's : 'The Wigeon is familiar to most Londoners, because it is kept on so many of the ornamental waters in the large urban parks. Wild Wigeon also visit the Metropolitan area in varying numbers every winter. Numbers of Wigeon used to frequent a certain mill-dam in North Surrey every winter, and I have known them linger in this spot so late into the spring that I was led to hope they might pass the summer there. This never happened, however, and they left to a bird sooner or later, reappearing the following winter. It would be difficult to enumerate all the Metropolitan waters where the Wigeon has been observed during the winter months. The bird may be seen on most lakes where fowl congregate at this season, Kingsbury being, or used to be, a favourite resort; Wanstead and Epping are others. There is reason to believe that wild Wigeon occasionally consort with their captive congeners on some of the ornamental waters of the Metropolis.

The Wigeon commences to arrive in our islands at the end of September, and from then onwards through the autumn its numbers increase. The return to the north begins in March, and continues through April. It is more or less gregarious during the whole winter, although this fact is not apparent in the London area, where its visits are irregular and in small numbers only. During its stay with us it is for the most part a coast bird. It flies well and powerfully, but with little noise ; 


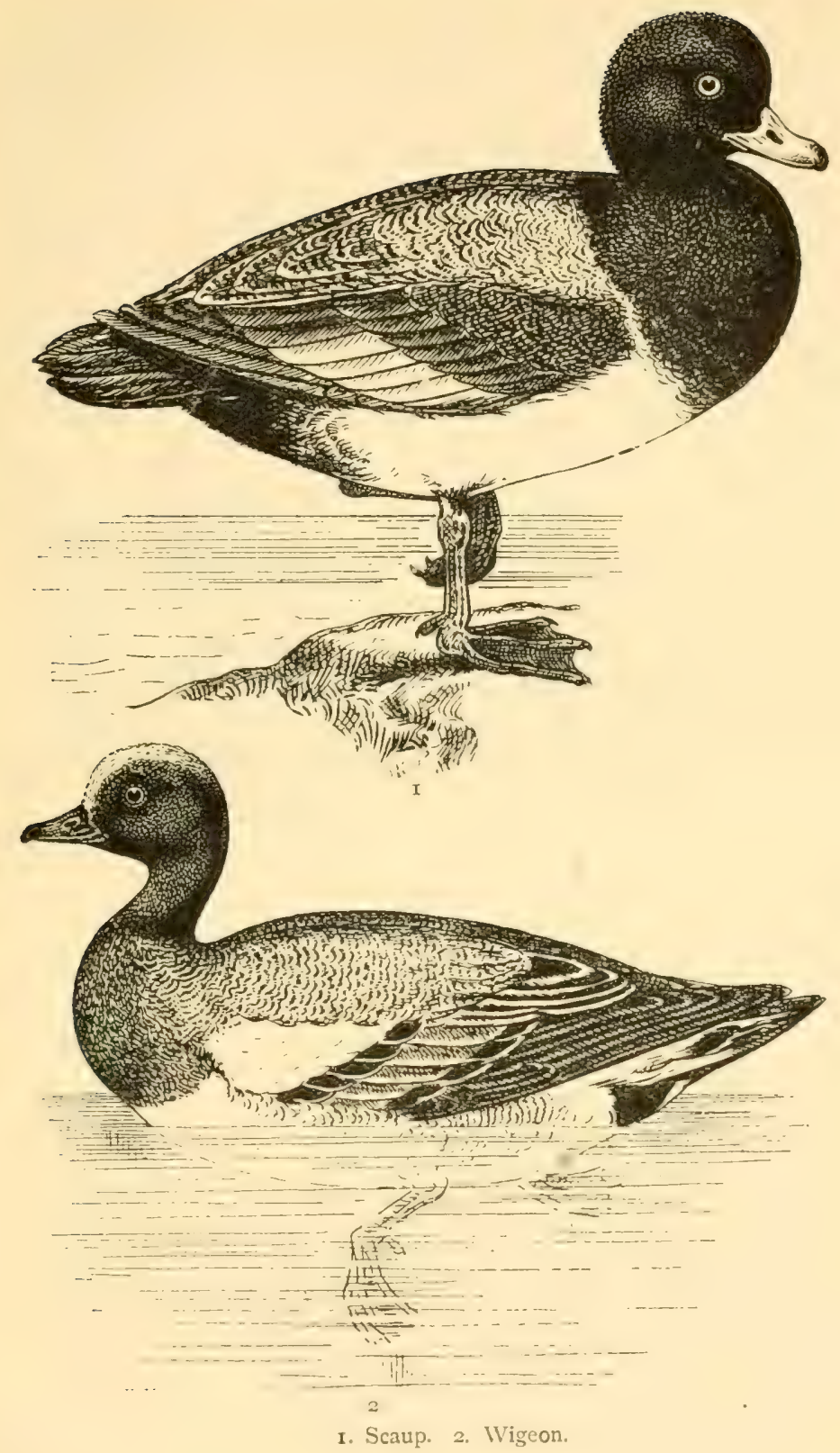





\section{THE WIGEON}

swims well, but does not dive for food, only when wounded. It also spends a good deal of time on land, but is always excessively wary and shy. Its cry is very characteristic, a clear and loud mee-ow, or wee-ow. Its food largely consists of grass, buds, leaves, and shoots of plants, insects, shrimps and molluscs. It feeds by day and by night if left unmolested, but at night only where it is much disturbed. A few Wigeon breed in Scotland and Ireland, but the majority repair to the Arctic regions for that purpose. The nest is made in May or June, well concealed near the waterside, and made of dry grass and other vegetation, lined with down. The six to ten eggs are creamy white or buffish white. Like other Ducks the female carefully covers them when voluntarily leaving the nest.

No detailed description of the Wigeon is necessary, but the following diagnostic characters will readily identify the species. The upper tail-coverts are grey, the under tail-coverts black; the upper part of the head is buff in the male; in the female the head is chestnut spotted with black. Length 18 to 20 inches. 


\section{THE POCHARD}

NYROCA FERINA

Local names in surrounding counties: "Dunbird," "Red-headed Dunbird" (Essex).

Status in British Avifauna : Best known as a common winter visitor, but breeds locally in many parts of England, Scotland, and Ireland.

Radial Distribution within fifteen miles of $\mathrm{S}$ t. Paul's: The Pochard nests in some numbers every year at the Tring Reservoirs, in Hertfordshire, some thirty miles only from the Metropolis. It is also found on Virginia Water, some twenty-three miles from London, but I am unable to say whether it breeds there. The bird also nests commonly in South Norfolk. It is not surprising, therefore, that the Pochard visits many of the Metropolitan waters during winter, and may sometimes be seen upon them in considerable numbers. Flocks of this Duck may be seen in winter on the Penn Ponds in Richmond Park and it is a fairly frequent visitor to Wanstead. Pochards also resort to Kingsbury Reservoir, the Welsh Harp, Osterley, Wimbledon Park, and various sheets of water in North Surrey and Kent. I am of opinion that individuals of this species from time to time consort with the wild-fowl on the lakes in the various London parks. During migration numbers must actually cross over the Metropolis, and are doubtless tempted to alight in these localities by their half-wild congeners.

The migratory Pochards that winter in our islands only reach them in October, and leave them in March and April. The Pochard belongs to the Diving Ducks (Fuligulina), a sub-family of the Anatida, distinguished by having a pendent lobe or membrane attached to the hind toe, and the tarsi are scutellated in front. All 324 


\section{THE POCHARD}

these Ducks habitually dive for their food. 'The Pochard spends most of its time on the water, swimming and diving, rarely visiting the land, where its gait is awkward and waddling. It dives with the same celerity as a Grebe. It is capable of rapid flight, but its progress when just rising is rather slow and laboured. It feeds both by day and night. Its principal food is of a vegetable nature-water weeds and marine plants-but insects, worms, molluscs, and crustaceans are also sought. It frequents fresh water as well as the sea, and during winter is more or less gregarious. In our islands the Pochard breeds in May, and the nest, always placed near to fresh water, is made amongst the dense, coarse vegetation round the banks, and in many cases is a floating structure. It is made of dry grass and other vegetable refuse, lined with down. The eight to fourteen eggs are greenish grey. The note of this Duck is a harsh kurr.

The diagnostic characters of the Pochard are the chestnut head and neck, and white vermiculated with black lower back (male); the white axillaries, white vermiculations on the upper parts, and absence of a white speculum (female). Length I7 to I9 inches. 


\section{THE TUFTED DUCK}

FULIGULA CRISTATA

Local names in surrounding counties:

Status in British Avifauna: A fairly common and widely distributed winter visitor, breeding locally throughout our islands.

Radial Distribution within fifteen miles of St. Paul's: The Tufted Duck is observed every winter in some part or another of the Metropolitan area. I strongly suspect that wild birds occasionally join the wildfowl on the Serpentine and other ornamental waters, and it is a more or less regular visitor to the larger reservoirs, Kingsbury, the Welsh Harp, and so forth. I have seen this bird on the Penn Ponds in Richmond Park; it frequents at times the large lake in Wimbledon Park; whilst I have records of it from sheets of water in the Wembley and Northolt districts. Some localities are much more favoured than others, whilst the numbers vary a good deal in successive winters. It is just one of those species that may be casually met with in winter on almost any large expanse of water anywhere within our limits. The Tring Reservoirs, some thirty miles from London, are a favourite winter resort of the Tufted Duck, and it is very probable that some of the individuals seen on the waters of our northern suburbs are wanderers from this locality. On the Essex side I may mention Wanstead as a resort of this species.

Those Tufted Ducks that winter in the British Islands migrate to them in October or November, and retire in March and April. The bird migrates at night, and during its stay with us is not only gregarious, but often consorts with other species, and frequents fresh water as well as the coast. Its habits are much the same as those of the preceding, but it is more nocturnal, and 326 


\section{THE TUFTED DUCK}

obtains its food chiefly at night. It flies well and powerfully, the noise of its rapidly beating wings being very characteristic in this species. It swims well, sitting rather low in the water, and is a wonderful diver, remaining on occasion as much as a minute below the surface. It passes the day generally well out from shore, sleeping on the water, rarely visiting land. Its note, not often heard, is a harsh kurr. Its food consists of aquatic insects, worms, grubs, lizards, frogs, and small fishes, together with the roots, stems, leaves, or buds of water plants. In our islands the nest is made in May. This is placed amongst the vegetation on the banks of some mere or pond, and is made of dry grass and other vegetable scraps, lined with down. The eight or ten eggs are greenish buff, and the female takes sole charge of the young.

The diagnostic characters of the Tufted Duck are the metallic green and purple crown and neck, the conspicuous crest, and the scarcely perceptible vermiculations on the upper parts (male); the white axillaries and alar speculum, and dark brown, unvermiculated head, neck, and upper parts (female). Length 16 to 17 inches.

The Scaup (Fuligula marila) is a thorough salt-water species which occasionally visits the Metropolitan area. I find it recorded from Wanstead as a casual winter wanderer. The diagnostic characters of the male are the metallic green and purple crown and neck and the white vermiculated with black lower back and scapulars; of the female, the white alar speculum and axillaries, and the varying amount of white vermiculations on the upper parts. Length 18 inches.

In conclusion I may also add that Swans (CYGNIN瓜) and Geese (Anserinex) are accidental visitors to the Metropolitan area, and pass over it in some numbers during their spring and autumn migrations. $\mathbf{V}$-shaped flocks of Geese may frequently be detected at a vast 


\section{THE BIRD-LIFE OF LONDON}

height winging their way over London, too high to be identified. The Mute Swan (Cygmus olor) is also a dweller on many of our ornamental waters, and numbers live in a semi-wild state on the Thames and elsewhere. A pair last year (1908) hatched a brood on the Paddington Canal near Willesden. Eton College enjoys the privilege of keeping Swans on the Thames, which mostly belongs to the Crown. The bird is of great historical interest to Londoners, and it enters largely into the Royal and civic life of the Metropolis.

Finally, mention may be made here of the many exotic species of Wild-fowl that live in more or less freedom upon or near the various ornamental sheets of water in the Metropolis. They are very interesting, and many of them are very beautiful birds; but their life-history is quite beyond the scope of the wild bird-life of London. 
THE BIRD-LIFE OF LONDON

\section{Local List for}

SPECIES





\section{N D E X}

\section{A}

Accentor modularis, $5^{8}$

Accipiter nisus, 19

Acredula rosea, II 4

Acroccpbalus arundinaceus, $6+$

Acrocephalus pbragmitis, 67

Egialitis biaticula, 272

Egialitis major, 272, 273

Alauda arborea, $\mathbf{1} 36$

Alauda arvensis, $\mathbf{I} 33$

Alcedo ispida, 246

Ampelis garrulus, 194

Analytical Table of the Birds of London, 8

Anas boschas, 317

Anserinex, 327

Antbus arboreus, 127

Antbus pratensis, I 30

Ardea cinerea, 308

Asio otus, 25

B

BARN Owl, 8, 21

Birds, History of British, $8 \mathbf{I}$

Birds, study of, in London, 2

Blackbird, 8, 27

Blackcap, 9, 78

Brambling, 9, 154

Bullfinch, I0, I8 I

Bunting, Cirl, 9, I 43

Bunting, Common, 9, 138

Bunting, Reed, 9, 146

Bunting, Snow, 9, I49

Bunting, Yellow, 9, I40
C

Caccabis rufa, 266

Caprimulgus europaus, 249

Carduelis elegans, 168

Certbia familiaris, 98

Chaffinch, 9, I 5 I

Charadrius pluvialis, 267

Chelidon urbica, 222

Chiffchaff, 9, 89

Coccotbraustes onlgaris, 162

Columba anas, 255

Columba palumbus, 252

Coot, II 305

Corvuis corax, 199

Corvus comix, 205

Corvus corone, 202

Corvus frugilegus, 207

Corvus monedula, 2 IO

Coturnix communis, 266

Cotyle riparia, 225

Crake, Corn, II, 299

Crake, Spotted, I I, 30I

Creeper, 9, 98

Crex porzana, 301

Crex pratensis, 299

Crossbill, 10, I83

Crow, Carrion, IO, 202

Crow, Hooded, I0, 205

Cuckoo, Io, $2+3$

Cuculus canorus, 243

Curlew, II, 278

Curlew, Stone, II, 273

Cygninæe, 327

Cygnus olor, 328

Cypselus apus, 10, 228 
D

Daulias luscinia, 45

Dove, Ring, I0, 252

Dove, Rock, 257

Dove, Stock, IO, 255

Dove, Turtle, IO, 258

Duck, Tufted, II, 326

E

Emberiza cirlus, I43

Emberiza citrinella, 140

Emberiza miliaria, 138

Emberiza nivalis, 149

Emberiza scboniclus, 9, 146

Erithacus rubecula, 42

Exotic species, 5

\section{$\mathrm{F}$}

Falco peregrinus, 12

Falco subbuteo, 14

Falco tinnunculus, I6

Falcon, Peregrine, 8, I2

Fieldfare, 8, 32

Flycatcher, Pied, 10, 189

Flycatcher, Spotted, Io, 186

Fork-tailed Petrel in London, 3

Fringilla calebs, I $5 \mathbf{I}$

Fringilla montifringilla, 154

Fulica atra, 305

Fuligula cristata, 326

Fuligula marila, 327

\section{G}

Gallinago scolopacina, II, 287

Gallinula cbloropus, 302

Game-dealers' shops, birds in, 4

Garrulus glandarius, 216

Gätke, Herr, 3

Gecinus viridis, $23 \mathbf{I}$

Geese, I I, 327

Goldcrest, 9, 92 ; in Big Wheel, 4 Goldfinch, 10, I68
Grebe, Great-crested, II, 3 I I

Grebe, Little, II, 314

Greenfinch, 10, 165

Guillemot, II ; in Thames, 3

Gull, Black-headed, II, 293

Gull, Herring, 297

Gull, Lesser Black-backed, 297

Gulls and Terns, other, 297

Gulls, Common, 297

\section{$\mathrm{H}$}

HaWfinch, IO, I62

Hedge Accentor, 9, 58

Heligoland, 3

Helodromas ocbropus, 277

Heron, II, 308

Hirundo rustica, 219

History of British Birds, $8 \mathbf{1}$

Hobby, 8, I4

Hydrocbelidon nigra, 298

\section{I}

IntRoduction, I

Iynx torquilla, 240

JACKDAW IO, 2 IO

Jay, I0, 216

K

Kestrel, 8, I6

Kingfisher, Io, 246

Kittiwakes, 297

L

Lanius collurio, 191

Lapwing, I I, 269

LARIN E, 297

Lark, Wood, 9, I36

Larus argentatus, 297

Larus camus, 297 
Larus. fuscus, 297

Larus ridibundus, 293

Ligurinus cbloris, 165

Limnocryptes gallimula, 290

Linnet, 10, 176

Linota cannabina, 176

Linota flavirostris, 179

Linota rufescens, 173

Local List, 329

Locustella navia, $6 \mathrm{r}$

London County Council, 6

London, migration over, 4; Pigeon colonies of, 257

London's remarkable bird records, 3

Long-eared Owl, 8, 25

Loxia curvirostra, 183

\section{M}

MAGPIE, IO, 213

Mallard, II, 317

Mareca penelope, 322

Martin, House, 10, 222

Martin, Sand, 10, 225

Merula torquata, 30

Merula vulgaris, 27

Metropolis, casual visitors to, 3; gradual extension of range of birds in, 5

Missel-Thrush, 8, 39

Motacilla alba, 120

Motacilla raii, 124

Motacilla sulpburea, $\mathbf{1 2 2}$

Motacilla yarrelli, II 7

Muscicapa atricapilla, 189

Muscicapa grisola, I86

\section{$\mathrm{N}$}

NATURE-KNOWLEDGE, I

Nature-study, I, 6

Nettion crecca, 320

Nightingale, 8,45

Nightjar, 10, 249
Numenius arquata, 278

Numenius phoeopus, 28I

Nuthatch, 9, I0I

Nyroca ferina, 324

O

Edicnemus crepitans, 273

Open spaces, bird-life in, 5

Open-air Studies in Bird-Life, 293

Osprey, at Richmond, 3

\section{$\mathrm{P}$}

PARKs and open spaces, keeper for, 6

Parks, bird-life in, 5

Partridge, II, 264

Partridge, Red-legged, I I, 266

Parus ater (sub-sp. britannicus), I IO

Parus caruleus, 107

Parus major, 104

Parus palustris, II 2

Passer domesticus, 157

Passer montanus, 160

Perdix cinerea, 264

Phasianus colcbicus, 26I

Pheasant, 10, 26I

Pbylloscopus rufus, 89

Pbylloscopus sibilatrix, 84

Pbylloscopus trochilus, 87

Pica caudata, I0, 213

Picus major, 234

Picus minor, 237

Pigeon colonies of London, 257

Pipit, Meadow, 9, I 30

Pipit, Tree, 9, 127

Plover, Golden, II, 267

Plover, Greater Ringed, II, 273

Plover, Grey, II, 268

Plover, Ringed, Ir, 272

Pochard, II, 324

Podiceps cristatus, $3 \mathbf{I I}$

Podiceps minor, $3 \mathrm{I} 4$

Pratincola rubetra, 53

Pratincola rubicola, 56 


\section{INDEX}

Puffin, II ; in Brook Street, 3

Pyrrbula vulgaris, I8I

\section{Q}

Quail, II, 266

\section{$\mathrm{R}$}

RaIL, Water, II, 30I

Rallus aquaticus, $30 \mathrm{I}$

Raven, I0, 199

Redpole, Lesser, IO, I73

Redshank, II, 277

Redstart, 8, 49

Redwing, 8, 34

Regulus cristatus, 92

Ring-Ouzel, 8,30

Rissa tridactylus, 297

Robin, 8, 42

Rook, IO, 207

Ruticilla pbonicurus, 49

\section{S}

Sandpiper, Common, II, 275

Sandpiper, Green, II, 277

Sandpiper, Wood, II, 277

Saxicola cenanthe, 5 I

Scaup, II, 327

School museum, 8

Schools, nature-study in, 7

Scolopax rusticula, 28+

Shrike, Red-backed, I0, I9I

Siskin, IO, I7I

Sitta cresia, I0I

Skylark, 9, 133

Smew, I I

Snipe, Common, II, 287

Snipe, Jack, I I, 290

Song 'Thrush, 8, 36

Sparrow, House, 9, I57

Sparrow, Tree, 9, 160

Sparrow-Hawk, 8, 19

Species banished from London, 2

Squatarola belvetica, 268
Starling, Io, 196

Sterna arctica, 298

Sterna cantiaca, 298

Sterna birundo, 298

STERNIN正, 297

Stonechat, 8,56

Stormy Petrel in London, 3

Strix flammea, 21

Sturnus vulgaris, 196

Swallow, 10, 219

Swan, Mute, 328

Swans, II, 327

Swift, I0, 228

Swift, Alpine, 3

Sylvia atricapilla, 78

Sylvia cinerea, 70

Sylvia curruca, 73

Sylvia bortensis, 75

Sylvia provincialis, $8 \mathbf{I}$

Syrnium aluco, 23

\section{$\mathrm{T}$}

Tawny Owl, 8, 23

Teal, Common, II, 320

Tern, Arctic, 298

Tern, Black, 298

Tern, Common, 298

Tern, Sandwich, 298

Terns, 298

'Titmouse, Blue, 9, ro7

Titmouse, Coal, 9, r ro

Titmouse, Great, 9, 104

Titmouse, Long-tailed, 9, II

Titmouse, Marsh, 9, II 2

Totanus calidris, 277

Totanus glareola, 277

Totanus bypoleucus, 275

Troglodytes parvulus, 95

Turdus iliacus, 34

Turdus musicus, 36

Turdus pilaris, 32

Turdus viscivorus, 39

Turtur auritus, 258

Twite, I0, I79

\section{4}




\section{INDEX}

$V$ anellus cristatus, 269

W

Wagtall, Grey, 9, I22

Wagtail, Pied, 9, I 17

Wagtail, White, 9, I20

Wagtail, Yellow, 9, 124

Warbler, Dartford, 9, 8 I

Warbler, Garden, 9, 75

Warbler, Grasshopper, 9, 6r

Warbler, Reed, 9, 64

Warbler, Sedge, 9, 67; at Islington, 4

Warbler, Willow, 9, 87
Warbler, Wood, 9, 84

Water Hen, II, 302

Waxwing, I0, 194

Wheatear, 8, 5 I

Whimbrel, Common, II, 28I

Whinchat, 8, 53

Whitethroat, 9, 70

Whitethroat, Lesser, 9, 73

Wigeon, II, 322

Wild-fowl, exotic, 328

Woodcock, II, 284; in Strand, 4

Woodpecker, Great Spotted, 10, 234

Woodpecker, Green, Io, 23 I

Woodpecker, Lesser Spotted, Io, 237

Wren, 9, 95

Wryneck, Io, 2.to

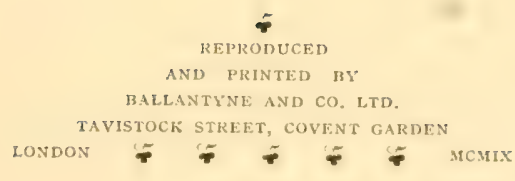








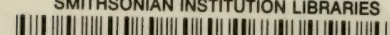
3908800257679 nhbird QL690.G70619 The bird-life of London / 